\title{
Composição e Distribuição dos Amphipoda (Crustacea: Peracarida) na Plataforma Continental entre São Sebastião e Peruíbe (São Paulo, Brasil)
}

\author{
Dissertação apresentada ao Instituto \\ Oceanográfico da Universidade de São \\ Paulo, como parte dos requisitos para \\ obtenção do título de mestre em Ciências, \\ área de Oceanografia Biológica. \\ Orientadora:
}

Profa. Drª . Ana Maria Setubal Pires Vanin

São Paulo

2009 
Universidade de São Paulo

Instituto Oceanográfico

Composição e distribuição dos Amphipoda (Crustacea: Peracarida) na plataforma continental entre São Sebastião e Peruíbe (São Paulo, Brasil)

\section{Carina Waiteman Rodrigues}

Dissertação apresentada ao Instituto Oceanográfico da Universidade de São

Paulo, como parte dos requisitos para a obtenção do título de Mestre em Ciências, área de Oceanografia Biológica.

Julgada em

Prof.(a) Dr.(a)

Conceito

Prof.(a) Dr.(a)

Conceito

Prof.(a) Dr.(a)

Conceito 
"Digo que sou uma mistura perfeita da sombra

$$
\text { daqueles que me amam }
$$

Tenho os lábios e o nariz de meu pai,

Tenho as mãos e beleza de minha mãe

Tenho o sorriso debochado e a felicidade que transpira na minha pele

que vem dos meus irmãos mais velho e do meio.

Mas acima de tudo, aquilo que é mais importante do que

As aparências físicas...

Tenho e sempre tive o amor incondicional

Obrigado por terem me aceitado como filha e como irmã."

Às minhas avós Georgina, Benedita (Dita) e Julieta.

Ao avô Carlos e Tio Jacob.

Obrigado pelo amor e carinho. 


\section{KT Tunstall - Miniature Disasters}

"I don't want to be second best

Don't want to stand in line

Don't want to fall behind

Don't want to get caught out

Don't want to do without

And the lesson I must learn

Is that I've got to wait my turn

Looks like I got to be hot and cold

I got to be taught and told

Got to be good as gold

But perfectly honestly

I think it would be good for me

Coz it's a findrance to my health

If I'm a stranger to myself

Miniature disasters and minor catastrophes

Bring me to my Knees

Well I must be my own master

Or miniature disaster will be

It will be the death of me

I don't have to raise my voice

Don't have to be underhand
Just got to understand

That it's gonna be up and down

It's gonna be lost and found

And I can't take to the sky

Before I like it on the ground

And I need to be patient

And I need to be brave

$\mathcal{N}$ eed to discover

How I need to behave

And I'll find out the answers

When I know what to ask

But I speak a different language

And everybody's taking too fast

Miniature disasters and minor catastrophes

Bring me to my knees

Well I must be my own master

Or a miniature disaster will be ... will be

I've got run a little faster

Or a miniature disaster will be ... will be

I need to know I'll last If a little

Miniature disaster hits me

It could be the death of me" 


\section{Agradecimentos}

À Prof. ${ }^{a}$ Dr. ${ }^{a}$ Ana Maria Setubal Pires Vanin, minha orientadora. Obrigado por ter acredito no meu potencial e ter me dado crédito na realização deste trabalho com os anfípodes, obrigada pela orientação e amizade.

Ao CNPq, pela concessão da bolsa de mestrado, sem a qual tudo seria mais difícil.

Ao Instituto Oceanográfico da Universidade de São Paulo, aos marinheiros do Navio oceanográfico Prof. W. Besnard, por terem possibilitado o desenvolvimento e a realização do Projeto ECOSAN.

Um agradecimento especial a Pablo Muniz e Fábio de Léo (o chefe e o sub-chefe), que sempre me apoiaram na época de estágio pelo Promarlam. Este mestrado eu ofereço a vocês dois, pois sem vocês eu provavelmente ainda estaria triando amostras, obrigado por terem me mostrado um sentido na triagem, um porque daqueles organismos estarem ali e levantar indagações sobre a vida marinha (bentônica é claro).

A Prof. ${ }^{a}$ Dr. ${ }^{a}$ Maria Teresa Valério Berardo, minha professora do Mack e dos anfípodes, muito obrigado pelo tempo que disponibilizou para me ensinar a identificar e por ter despertado o amor que eu tenho por estes organismos tão fofos, bem acho que este adjetivo poucos vão concordar.

Agora gostaria de agradecer àqueles que entenderam pelo menos em parte que PIRITUBA é um bairro e não uma cidade (mesmo que sejam poucos que acreditem nesta afirmação!). Mas que para uma pessoa que vive de transporte público às vezes Pirituba fica bem mais longe do que realmente é. Ter amigos que um dia me ofereceram uma cama, colchão no chão ou até mesmo um sofá foi essencial. Não tem como agradecer a vocês por esta atenção especial. Aí segue os nomes dos alojamentos amigos que me hospedei: Darcião com a piscina não planejada no banheiro; Sandrinha pelo quarto mais chique em que dormi, com sofá e tudo; Arthur no seu pequeno apê, mas que tinha o Zóio, a lula zoiuda; Déa que não só me ofereceu uma cama mas também duas semanas e meia sozinha no seu apê com a simples obrigação de cuidar da gatinha fofa Kirra; Cintia Maria, esta literalmente dividiu a cama...sinto sua falta amiga; Caia (Caião) que já me ofereceu dois tetos um no Morumbi e outro no Butantã e lá acabou me colocando por fim na senzala..hehehe; Maria depois de um heavy hour nada como deitar em um colchão inflável e as meninas Naty (Natiely) e Thaís (Thathá) que no fim eu já me considerava a roomate, só faltou ajudar nas contas, pois foram tantas às vezes que eu me alojei no apê de vocês que perdi até a conta e ainda ganhava carona para Pirituba no dia seguinte ehhhh MARAVILHA. A todos muitíssimo obrigada....por causa de vocês tive muitos sonos tranqüilos.

Ao Laboratório mais social do IO e com as pessoas mais charmosas e cheias de personalidade é claro que eu estou falando do Laboratório de Ecologia Bêntica, onde eu trabalho... hehehe. Primeiro a mais importante Sandrinha $=$ SanSan $=$ San muito obrigado por ter me agüentado todos estes anos desde quando era uma estagiária super pentelha até hoje. Não que eu tenha deixado de ser pentelha hahaha, muito obrigado pela força que me deu tanto na hora de estudar para o mestrado, como durante o mestrado e possivelmente depois do mestrado, você é uma pessoa super especial, uma profissional e amiga super atenciosa e tem sido uma maravilhosa experiência conviver com você todos estes anos. Natiely como dizer...você é tudo aquilo que eu quero ser profissionalmente, não é a toa que eu sempre vou atrás de você quando minha mente se perde, mas acima disso você é uma amiga maravilhosa, sempre demonstrando a sua opinião mesmo quando eu não queria escutar, sempre irei te admirar independentemente se você esteja a dois passos de mim, no Uruguai ou no outro lado do oceano, mas não se esqueça eu sou a primeira posdoc que você vai orientar quando o teu lab estiver pronto. Kátia, no começo a gente não se trombava (isso não é mistério pra nenhuma das duas), mas depois eu descobri a amiga em 
você. A ti eu devo o Chile (Coquimbo - La Serena) que eu conheci e amo e a oportunidade de ter conhecido as minhas amigas gregas e a americana. A ti eu devo a força que me deu para lutar no campo profissional e não me abalar. As três muito obrigada, amo as três e cada uma me marcou de uma maneira diferente. À Michele, com seu pique surreal para a vida, espero que seus projetos de vida dêem certo, você é uma batalhadora, Te Adoro! À Evelyn que entrou a pouco no Lab espero que você consiga aquilo que almeja, beijos. Ao Pedro que levou um susto ao entrar no mestrado logo de cara...hehehehe, e agora está estudando na Argentina, você vai ver que a gente perde alguns cabelos outros ficam brancos, mas no final tudo dá certo.

À Turma Arrasa Gata acredito que vocês já estão careca de saber que o trio Arrasa: Caião, Bety balanço e Loira (Carol Siliprandi) vivem eternamente no meu coração. Caião, minha irmã espiritual:Você é uma pessoa de luz que vive entre nós e tudo que você conseguiu foram frutos reais de uma mulher batalhadora que nunca deixou os problemas da vida te abalarem por completo, fico muito feliz por poder trilhar com você nesta vida e nossa amizade creio que nasceu há muitas eras atrás e continuará por muitas outras eras. Bety balanço: Como alguém pode deixar de ser sua amiga... hahaha louca com certeza esta pessoa será, com seu jeito hilário de ser, com a maneira atenciosa que vc tem com aqueles que gosta, com suas idéias filosóficas tão complexas para uma piritubana... hehehehe. Você também é outra pessoa que sempre vou levar junto do meu peito, mas Bety sem vergonha se entregue no sofá e assista aqueles filmes Hollydianos bobinhos tipo Blockbuster: Homem Aranha, X-Men, Harry Potter hahahahaha. LOIRAAAAA: uma das pessoas mais felizes e loucas que eu já encontrei na minha vida, espero que nunca deixemos de pular no meio do corredor após um longo período sem se ver com a mesma alegria de ser....vai com fé Loira que você vai conseguir o que quer dessa vida. As Três nem preciso falar que eu as amo muitoooooooooo. Fico feliz por ter ido na saída de campo de geo com vocês e lembre-se : DESCE PRO PLAY E ARRRRRAAAASSSSSSAAAAA GAAAAATTTTTAAAAAA!!!!!!!!!!

Falando em saída de Geo um obrigado especial a galera do Dof Samara, Marcelão e Prof. Foca. Esta viagem foi a melhor de todas, a melhor aula de campo que eu tive no mestrado junto com os melhores conselhos. Carrego os três em um lugar especial no meu peito, beijos.

À Família bahiana: Mau e Arthur. Aposto que o Mau achou estranho q eu não o coloquei no Lab dos charmosos...hehehehehe. Mau você foi chegando no lab tomou posse do teu lugar como todo leonino faz e nos marcou com sua alegria e risada contagiante. Os dias passam e você me surpreende a cada dia, com seu jeito carinhoso e atencioso para com o próximo. Te amo amigo! Arthur, o campineiro mais pentelho e narcisista que eu conheci..hehehe, muito obrigado pela xícara gigante dos Simpsons e a cafeína sempre querida à tarde. E obrigado pelos conselhos sobre a vida. Amo muito os dois muitooooo mesmo. Sinto muita falta da casinha, das caminhadas forçadas, quer dizer maratonas forçadas que o Arthur nos obrigava a fazer, sinto falta das risadas. Mas sempre teremos o barquinho, presente de Yemanjá para nunca esquecermos daquele paraíso na Terra. CREEEEUUUUUU!

Ao Lab do lado... ainda vou fazer o movimento pra derrubarmos a parede que existe entre estes dois labs. Paulinho, deixe a gente derrubar a parede vai...hahahahaha. Ao Paulinho Dark Vader.... muito obrigado por ter me dado a oportunidade de viajar com vocês, sempre guardarei a viagem para Abrolhos, não como uma simples coleta, mas uma viagem maravilhosa com uma pessoa surpreendente como você. À Karin, a mais quieta da turma, mas que também nunca deixou de soltar as suas pérolas...hehehehehe. Te adoro, Ká.À Cintia capixaba e os inesquecíveis Heavy Hours (Reloaded, Revolution e o Templo da Perdição) sempre sentirei falta do seu "leve" desequilíbrio para o lado direito ou era esquerdo...enfim sempre com a xícara perguntando do café e sumindo logo depois. À Paulinha, aos churrascos na sua casa, aos pães de queijo e a pentelhação todos os dias. À Déa, a manezinha da Ilha. Muito obrigado pela estadia no apê e pelo carinho que me deu nestes anos e ao jogo imagem e ação....hahahahaha. À Maria sempre pedindo 
desculpas por tudo..hehehehe...sempre tão atenciosa. À Paula Cris e Tauane que entraram agora na turma muitos beijos às duas.

Thathá.....ainda lembro falando pra Natiely: "Tem certeza que você vai morar com essa garota" Hahaha. Ainda bem que ela foi, assim pude conhecer a Thathá, uma das amigas mais atenciosas que eu tenho. Não tem como te agradecer pelos conselhos, pelas baladas perdidas na Bio, pelas risadas, pelo lenço que enxugou muitas lágrimas que eu vergonhosamente deixei rolar e muito obrigado pelas broncas que me dava para eu voltar à realidade (bem as broncas a Natiely também tem participação). Te amo Thathá.

Galera do Mack: ao Bica amigo querido, que entrou comigo no mestrado ainda lembro da sua cara de surpresa quando viu seu nome na lista... sabe q te adoro. Fausto, convivi pouco com você no Mack, também resolveu largar a gente para morar em Floripa....ainda bem que voltou, obrigado pela hospedagem na sua casa em Ubatuba e é sempre um prazer trabalhar com você. Mimes e Alê (Dr.) amigos queridos que infelizmente não consigo ver com tanta freqüência, mas adoro vocês. À Valéria Fabiane, Valdete, amiga que entrou comigo no Mack as duas 499, sempre sinto sua falta, creio que você é uma das únicas que me conhece de olhos fechados. À Dora, baiana sinto sua falta. Gui, habbib, adoro ter vc como amigo, adoro seu jeito simples de ver as coisas, simplesmente adoro vc.

Darcião meu amigo lindo, o primeiro com quem eu embarquei, sinto muito sua falta no IO, mas sempre estarei do seu lado e suas idéias. Ao Bar do Museu, ao Bar Mangueira e que a amizade nunca enfraqueça. Ao Leo e Telma Raquel amigos de Darcião e meus também sinto falta do Nego poeta e da Nega Flor. À MC amiga companheira de Cajaíba e IO, sinto sua falta baixinha não some assim não.

À Edna que mesmo antes de ter descido para a diretoria, sempre acreditou em mim. Como a Caião diz, você é nossa pequena bruxa, tudo o que a Edna fala com certeza vai se concretizar. Muito obrigado por sua amizade e por ter quebrado muitos galhos na diretoria quando queria falar com a orientadora. Te Adoro muito. À Cris, que também me ajudou a marcar reuniões com a orientadora durante o mestrado. Valeu Cris! Beijos.

À Juliana Gurgel pessoa maravilhosa, que tem o dom de sumir, mas que sempre manteve o mesmo astral. À Cintia Maria, aquela q profetizou que o IO não seria mais o mesmo sem ela, realmente estava certa, junto com Fábio, outro amigo que tive oportunidade de conhecer, ao Jujú e Saulo pelo um real que tão gentilmente arrecadaram para o tapa de cinema na ECA, ao Ha e Lú, Betinho elembrarei do Milo, Quinta na ECA, Bio e tantas outras baladas e conversas com vocês em que eu dava muita risada. Beijos.

Ao Valter primeiramente pela amizade, por todas as nossas conversas e conselhos durante o café, e em segundo pela ajuda na parte de informática e Xerox. VALEU VALTÃO! Beijos.

Aos namorados, noivos, maridos: Pedrão, Clayton, Dú, Pablo, Djalma, Piriquito, Serginho e Marcos, adoro vocês cada um à sua maneira. Ao Pedrão com toda sua altura e jeito de falar com as mãos, ao Broto da Karin o Clayton que é o churrasqueiro e violeiro oficial da turma hehehehe e nem adianta reclamar, $D u ́$ com sua excentricidade na hora de acender a churrasqueira com o ventilador ou fazer café no meio do churras, Pablo raramente te vejo, mas obrigado também pela confiança de ter me deixado morar na casa de vocês, Djalma, sua guitarra e seu jazz, Piriquito (Carlos da Valdete) sempre vou lembrar das nossas conversas em que deixávamos a Val louca, Serginho pela oportunidade de ter conhecido você e o seu trabalho na ONG e Marcos, obrigado por tudo. 
Ao Lab da Química (DOF) Josi (Enfermeira Josi), Ana Cecília (Ciça) e Diego (outro campineiro). Não imaginava encontrar amigos no DOF..hehehehe, mas acabei encontrando. Josi $e$ sua moto, amiga batahadora, sempre companheira, com seu jeito de alemã super educada. Ciça, conheci no embarque pelo ECOSAN, com certeza a viagem foi bem mais engraçada com você, sem falar é claro da companhia junto com o Michel no show inesquecível do Dave Matthews Band....nunca vou esquecer da gente lá no meio da muvuca tentando ver algo, tentando ver o Dave dançar. O Di, que se não fosse os problemas da PAE, talvez não teríamos nos encontrado, um brinde à voadora que você desejou dar na mulherzinha simpática e ao The Fifties que eu te apresentei. Muitos beijos aos três.

À Oficina dos Mendigos por toda ajuda que nos deram, por todos os churrascos que eu ajudei a organizar, pelas risadas e amizade. Um beijo especial para o Seu Nelson e para o Piauí. Hoje me considero parte da Família dos Mendigos. Beijos para todos.

Ana Maria Thiago de Souza obrigado pela ajuda na identificação de uma parte dos anfípodes para o mestrado. Fico feliz por você ter se encontrado e estar trabalhando naquilo que gosta.

Um beijo geral para outros amigos: Mônica, Bia Torrano (mais Bia Torrando hahahaha), Maysa, Fábio magro, Cabeça, Luiz (técnico), Maisa (técnica), Lurdes (técnica), Cabelo, Carla (Carlota) e Fabi, Carol, Lú, Paulinha e Andrea (as quatro da Thaïs), Fabiano, Claúdia, Ricardo e Márcio (os três da ONG), Zé Dú, Lilian, Ligia (Fausto), Michel e Frango (os dois da June), Fábio Prior, Ricardão, Valtão (dos transportes), Prof. Turra e Márcia.

Ao pessoal da lanchonete....sempre me salvando de manhã com aquele suco de laranja e o enroladinho de presunto e queijo.. Beijo à Didi e ao resto da trupe.

Aos funcionários da biblioteca do IOUSP pela eficiência, disponibilidade e paciência: Cidinha, D. Rai que sempre me ajudaram a encontrar as revistas mais velhas que tinha na biblioteca. Muito obrigado pela atenção.

Um beijo para a galera do Village e Vila Zatt que hoje em dia dificilmente eu vejo: Mauricinho, Vasco, Puga (irmão mais novo), Aline (A), Aliny, Júlio, Dennis, Thiago, Ayslan, Tiago (Iara), Rafael, Mirela, Fabinho Negão (irmão mais velho), Guela, Pryscilla e Lucyara.

Àqueles que possivelmente nunca leram este mestrado, mas só os possíveis trabalhos que sairão deste trabalho (pelo menos é o que eu almejo) Lydia Anagnostopoulou, Niki Chartosia, Michalis Mavidis, Tina Bell, Juan Pablo Saez, Ivan Hinojosa e Sergio Andrés Marchant Rojas, estes se resumem em parte àqueles que eu sempre sinto falta, àqueles que eu sempre lembrarei em todos os meus aniversários, pois eles marcaram um deles, sempre lembrarei deles quando alguém comentar da Grécia, do Chile e que possivelmente ainda irei encontrar em viagens e em congressos pelo mundo. E ao francês Joannès Berque pela amizade e aos conselhos profissionais que me dá até hoje, assim como os gregos espero te encontrar em julho.

Começando na família, à mana Daniela, sempre juntas desde de pequenas, acho que você é a única que eu nunca briguei nem mesmo levantei a voz, fato incrível. As viagens para Campinas na adolescência, as baladinhas que íamos em Sampa, e é claro sempre lembrando de nossa promessa: "Na varanda, cada uma bem velha sentada olhando a paisagem, lembrando da nossa vida, rindo de tudo e comendo pipoca.... hahahaha só quero ver se a gente vai ter dente pra isso". Obrigado por existir, obrigado por ser minha irmã, obrigado por tudo....minha vida não seria a mesma sem você irmã. E iremos sim viajar para a Europa, pois precisamos juntar muita memória para a varanda.

Às primas Cás (Carla e Camila), Ká (Karen) e Dani (Daniela) e Michele, e aos primos Carlos, Rodrigo, Cris, Lucas, Maéverson Carlos, Wellington, Fábio e Tibau. Gente, eu sei que sou a prima mais 
distraída e isolada, que sumo e raramente apareço, mais saibam que amo vocês. E também às noivas dos primos Natália (Cris) e Tati (Wellington).... adoro a idéia de ter vocês como primas. E às duas jóias raras da família meus diamantes negros Rafa e Davi, lindos. E outra jóia rara que é a Bibi, a prima Michele acertou nessa, eu te adoro prima apesar de você sempre pedir pra sua filha me chamar de Cachina. Às Tias e tios Ana Lúcia, Tânia, Izilda, Tio Zezinho e Teresinha, Marlene, Sales, Olavo, Tia Maria, Reinaldo, Júlia, Beti e Oswaldo. À última, mas nem por isso a menos importante, à vó Dita, aos ensinamentos que me deu nesta vida, tenho muito orgulho de ser sua neta.

Às minhas cunhadas Paula e Vanessa, adoro as duas, com certeza meus irmãos acertaram na escolha de duas pessoas tão gente boa como vocês. E que venham os sobrinhos, vamos gente começar com a produção senão a D. Luzia vai enlouquecer...hehehehe. Mil beijos nas duas.

Agora aos QUATRO que resumem a minha existência: Seu Helio, meu pai querido, D. Luzia, minha amada mãe, ao irmão mais velho Erick e ao irmão do meio William. Eu digo que sou a mistura dos quatro, sou teimosa e persistente como meu pai, orgulhosa e um dia uma maravilhosa cozinheira como minha mãe, amiga verdadeira como o mais velho e tento ser batalhadora como o do meio.... hehehehe um dia consigo. Amo vocês incondicionalmente, às vezes demoramos para entender quem realmente nos ama, quem são aqueles que dariam a própria vida sem vacilar pela nossa felicidade. E hoje eu sou feliz pois eu entendi isso. Amo vocês, tenho muito orgulho de ser a filha do Seu Helio e da D. Luzia e irmã caçula e única do Erick e William.

AHH! Estava esquecendo. ao Harry Potter (e Sirius Black), à série Twilight (Edward Cullen), ao Calvin e Harold e aos anfipóides.

“De Pirituba ao mundo!”

Atenciosamente,

Carina,

a Calininha,

Cau, Cacau,

Caulene Maria ou Cauquete. 


\section{ÍNDICE GERAL}

Índice de Tabelas $\quad$ iii

Índice de Figuras $\quad$ v

Resumo vii

Abstract viii

1 INTRODUÇ̃̃O

2 OBJETIVOS

3 ÁREA DE ESTUDO

3.1 Características gerais - plataforma continental sudeste-sul 7 brasileira e Baixada Santista

3.2 Hidrografia e sedimento da região 9

4 MATERIAL E MÉTODOS

$\begin{array}{ll}\text { 4.1 Trabalho de campo } & 12\end{array}$

$\begin{array}{lr}\text { 4.2 Trabalho de laboratório } & 14\end{array}$

$\begin{array}{ll}\text { 4.3 Tratamento dos dados } & 15\end{array}$

$\begin{array}{lr}5 \text { RESULTADOS } & 19\end{array}$

$\begin{array}{lr}\text { 5.1. Dados ambientais } & 19\end{array}$

$\begin{array}{lr}\text { 5.1.1 Temperatura e Salinidade } & 19\end{array}$

$\begin{array}{lr}\text { 5.1.2 Sedimento } & 29\end{array}$

$\begin{array}{ll}\text { 5.2 Dados biológicos } & 37\end{array}$

$\begin{array}{ll}\text { 5.2.1 Composição Específica } & \mathbf{3 7}\end{array}$

$\begin{array}{lr}\text { 5.2.2 Classificação funcional } & \mathbf{4 0}\end{array}$

5.2.3 Freqüência de Ocorrência Relativa $4 \mathbf{4 3}$

5.2.4 Densidade $\quad \mathbf{4 5}$

$\begin{array}{lr}5.2 .5 \text { Biomassa } & 49\end{array}$

5.2.6 Riqueza de espécies, Diversidade e Eqüitatividade $\mathbf{5 0}$

5.2.7 Distribuição batimétrica e variação sazonal das espécies 
5.3 Estrutura das comunidades de Amphipoda

5.3.1 Inverno $\quad \mathbf{5 4}$

$\begin{array}{lr}\text { 5.3.2 Verão } & \mathbf{5 9}\end{array}$

5.4 Distribuição vertical das espécies $\quad 65$

6 DISCUSSÃO

$\begin{array}{ll}\text { 6.1 Fatores Ambientais } & 76\end{array}$

$\begin{array}{lr}\text { 6.2 Comunidades de Amphipoda } & 78\end{array}$

$\begin{array}{ll}\text { 6.2.1 Composição e distribuição da fauna de anfípodes } & \mathbf{7 8}\end{array}$

6.2.2 Fatores estruturadores das comunidades de anfípodes $e \quad \mathbf{8 3}$ determinantes da sua distribuição

6.2.3 Estrutura funcional das comunidades de anfípodes $\quad \mathbf{8 8}$

$\begin{array}{ll}\text { 6.2.4. Distribuição vertical } & \mathbf{9 0}\end{array}$

7 CONCLUSÕES $\quad 96$

8 CONSIDERAÇÕES FINAIS $\quad 97$

9 REFERÊNCIAS BIBLIOGRÁFICAS $\quad 98$

ANEXOS 


\section{Índice de Tabelas}

Tabela 1. Coordenadas geográficas das estações amostradas na plataforma continental entre São Sebastião e Peruíbe, SP, no período de 26 de agosto a 4 de setembro de 2005 (inverno) e 13 a 22 de fevereiro de 2006 (verão).

Tabela 2 - Valores de Profundidade (m), Salinidade e Temperatura ( $\left.{ }^{\circ} \mathrm{C}\right)$ da água de fundo, verificados para cada estação amostrada nas campanhas de inverno/2005 e verão/2006 na plataforma continental entre São Sebastião e Peruíbe, SP.

Tabela 3. Granulometria e classificação dos sedimentos das amostras coletadas no inverno de 2005 na plataforma continental entre São Sebastião e Peruíbe, SP.

Tabela 4. Granulometria e classificação dos sedimentos das amostras coletadas no verão de 2006 na plataforma continental entre São Sebastião e Peruíbe, SP.

Tabela 5. Porcentagens médias de matéria orgânica $(\mathrm{MO} \%)$ e carbonato $\left(\mathrm{CaCO}_{3}\right)$ nos sedimentos coletados na plataforma continental entre São Sebastião e Peruíbe, SP para as duas campanhas.

Tabela 6. Classificação ecológica (ocupação, mobilidade e grupo trófico) das espécies de anfípodes encontrados na plataforma continental entre São Sebastião e Peruíbe, SP.

Tabela 7. Distribuição batimétrica, Freqüência de Ocorrência Relativa (FOR) e categorias das espécies em relação às freqüências de todas as espécies coletadas nas duas campanhas (inverno e verão).

Tabela 8. Resumo do teste de Mann-Whitney $(\alpha=0,05)$ para a densidade, biomassa, riqueza de espécies, diversidade e eqüitatividade obtidas nos períodos amostrados (inverno/2005 e verão/2006) na plataforma continental entre São Sebastião e Peruíbe, SP.

Tabela 9. Riqueza de espécies (S), diversidade específica [H'(loge $]$ e eqüitatividade (J') das estações nas duas campanhas (inverno/2005 e verão/2006) na plataforma continental entre São Sebastião e Peruíbe, SP.

Tabela 10. Resultados dos testes pareados da Análise de Similaridade (ANOSIM) para os grupos obtidos na Análise de Agrupamento Modo Q.

Tabela 11. Densidade relativa (\%) das espécies de anfípodes nos quatro grupos de estações, da campanha de inverno de acordo com os resultados da análise SIMPER.

Tabela 12. Média dos parâmetros biológicos e abióticos dos grupos formados no inverno: Riqueza de espécies ( $\mathrm{S}$ ), Densidade (ind./0.09 $\left.\mathrm{m}^{2}\right)$, Diversidade $\left(\mathrm{H}^{\prime}\right)$, Equitatividade (J'), Biomassa (mg./0,09 m²), Silte + Argila (\%) e Profundidade (m).

Tabela 13. Resultados dos testes pareados da Análise de Similaridade (ANOSIM) para os três grupos obtidos dentro do grupo A na Análise de Agrupamento modo Q. 
Tabela 14. Densidade relativa (\%) das espécies de anfípodes nos quatro grupos de estações da campanha de verão de acordo com os resultados da análise SIMPER.

Tabela 15 - Média dos parâmetros biológicos e abióticos dos grupos formados no verão: Riqueza de espécies $(\mathrm{S})$, Densidade (ind./0.09 $\left.\mathrm{m}^{2}\right)$, Diversidade $\left(\mathrm{H}^{\prime}\right)$, Equitatividade (J'), Biomassa (mg/0,09 m²), Silte + Argila (\%) e Profundidade (m).

Tabela 16 - Valores médios da riqueza de espécies (S), diversidade ( $\left.\mathrm{H}^{\prime}\right)$ e densidade (ind.0,09 $\mathrm{m}^{-2}$ ) nos diferentes estratos e faixas batimétricas (zona costeira, zona intermediária e zona profunda) nas duas campanhas, agosto de 2005 (inverno) e fevereiro de 2006 (verão), na plataforma continental entre São Sebastião e Peruíbe, SP. 


\section{Índice de Figuras}

Figura 1. Área de estudo com a malha amostral

Figura 2. Aparelhos utilizados na coleta: CTD e Box Corer.

Figura 3. Procedimento de amostragem dos três estratos (superfície, meio e inferior).

Figura 4. Perfis de temperatura e salinidade para as estações coletadas na campanha de inverno (agosto e setembro de 2005) na plataforma continental entre São Sebastião e Peruíbe, SP.

Figura 5. Perfis de temperatura e salinidade para as estações coletadas na campanha de verão (fevereiro de 2006) na plataforma continental entre São

Sebastião e Peruíbe, SP.

Figura 6 Diagramas T-S para os pares de dados obtidos nas estações das campanhas de inverno e verão na plataforma continental entre São Sebastião e

Peruíbe, SP.

Figura 7. Distribuição das frações granulométricas nos diferentes estratos (superfície, meio e inferior) das amostras de sedimento coletadas na campanha de inverno, nas estações da plataforma continental entre São Sebastião e Peruíbe, SP.

Figura 8. Distribuição das frações granulométricas nos diferentes estratos (superfície, meio e inferior) das amostras de sedimento coletadas na campanha de verão nas estações da plataforma continental entre São Sebastião e Peruíbe, SP.

Figura 9. Porcentagens médias de matéria orgânica (MO\%) e carbonato $\left(\mathrm{CaCO}_{3}\right)$ contidas nos diferentes estratos da coluna sedimentar das amostras coletadas para as duas campanhas na plataforma continental entre São Sebastião e Peruíbe, SP.

Figura 10. Densidade média dos anfípodes nas estações amostradas nas duas campanhas na plataforma continental entre São Sebastião e Peruíbe, SP.

Figura 11. Densidade das espécies de anfípodes na plataforma continental entre São Sebastião e Peruíbe, SP.

Figura 12. Biomassa média das estações amostradas nas duas campanhas na plataforma continental entre São Sebastião e Peruíbe, SP.

Figura 13. Valores da diversidade específica de Shannon [H'(loge $)$ e Eqüitatividade de Pielou (J') para as estações de coleta das campanhas inverno/2005 e verão/2006 na plataforma continental entre São Sebastião e Peruíbe, SP.

Figura 14. Densidade relativa da distribuição dos anfípodes de diferentes modos de vida nas estações amostradas nas duas campanhas inverno/2005 e verão/2006 na plataforma continental entre São Sebastião e Peruíbe, SP. 
Figura 15. Análise de Agrupamento em modo Q para a campanha de inverno (agosto de 2005) na plataforma continental entre São Sebastião e Peruíbe, SP.

Figura 16. Análise de Ordenação (n-MDS) para a campanha de inverno (agosto de 2005) na plataforma continental entre São Sebastião e Peruíbe, SP.

Figura 17. Análise de Agrupamento em modo Q para a campanha de verão (fevereiro de 2006) na plataforma continental entre São Sebastião e Peruíbe, SP.

Figura 18. Análise de Ordenação (n-MDS) para a campanha de verão (fevereiro de 2006) na plataforma continental entre São Sebastião e Peruíbe, SP.

Figura 19. Densidade de anfípodes obtidos nas estações de cada estrato nas duas campanhas na plataforma continental entre São Sebastião e Peruíbe, SP.

Figura 20. Distribuição vertical em três estratos das espécies de anfípodes nas estações de inverno/2005 amostradas na zona costeira na plataforma continental entre São Sebastião e Peruíbe, SP.

Figura 21. Distribuição vertical em três estratos das espécies de anfípodes nas estações de verão/2006 amostradas na zona costeira na plataforma continental entre São Sebastião e Peruíbe, SP.

Figura 22. Distribuição vertical em três estratos das espécies de anfípodes nas estações de inverno/2005 amostradas ao redor da isóbata de $30 \mathrm{~m}$ na plataforma continental entre São Sebastião e Peruíbe, SP.

Figura 23. Distribuição vertical em três estratos das espécies de anfípodes nas estações de verão/2006 amostradas ao redor da isóbata de $30 \mathrm{~m}$ na plataforma continental entre São Sebastião e Peruíbe, SP.

Figura 24. Distribuição vertical em três estratos das espécies de anfípodes nas estações de inverno/2005 amostradas entre as isóbatas de 50 e $100 \mathrm{~m}$ na plataforma continental entre São Sebastião e Peruíbe, SP.

Figura 25. Distribuição vertical em três estratos das espécies de anfípodes nas estações de verão/2006 amostradas entre as isóbatas de 50 e $100 \mathrm{~m}$ na plataforma continental entre São Sebastião e Peruíbe, SP. 


\section{Resumo}

A composição e estrutura da comunidade de Amphipoda da Plataforma Continental adjacente à Baixada Santista foi estudada em relação aos fatores ambientais. Vinte e uma estações foram amostradas em agosto e setembro de 2005 (inverno) e em fevereiro de 2006 (verão), à bordo do N/ Oc. "Prof. W. Besnard" como parte do projeto interdisciplinar "ECOSAN". As amostras foram obtidas com um box corer de 0,09 $\mathrm{m}^{2}$ em duplicata. A composição de espécies e as variáveis da comunidade (densidade, biomassa, diversidade e eqüitatividade) foram determinadas. Os parâmetros ambientais obtidos foram profundidade, temperatura, salinidade, diâmetro dos grãos, matéria orgânica e carbonato contidos no sedimento. Análises de Cluster, n-MDS, similaridade e BIO-Env foram realizadas para interpretar os resultados. Quarenta e uma espécies e dezenove morfoespécies foram encontradas e classificadas em vinte e quatro famílias nas duas campanhas. O verão apresentou os maiores valores de densidade e uma dominância marcante de poucas espécies. Ampelisca paria, Metharpinia sp.n., Microphoxus moaresi, Urothoe sp.n., Gitanopsis sp. e Photis brevipes foram predominantes nos dois períodos amostrados. A diversidade e densidade foram baixas nas estações próximas à desembocadura da Baía de Santos e ao sul, em frente à Peruíbe. Tanto as análises de ordenação quanto as de similaridade mostraram que, em função da fauna de Amphipoda presente, a plataforma esteve dividida em quatro áreas no inverno e quatro no verão, onde a profundidade mostrou ser um fator preponderante nessa repartição. Foi encontrada uma comunidade típica de zona costeira, outra de plataforma externa e uma terceira contendo espécies de ambas. A distribuição vertical da fauna no sedimento mostrou que houve uma diminuição na densidade e diversidade do estrato de superfície em direção ao estrato inferior. Em algumas estações das zonas intermediárias e profunda houve um decréscimo menos abrupto da densidade e da riqueza de espécies em direção aos estratos mais profundos, ocorrendo a dominância de diferentes espécies nos diferentes estratos Palavras - chave: Amphipoda; macrofauna; plataforma continental; Baixada Santista. 


\begin{abstract}
The composition and structure of the Amphipoda community from the continental shelf adjacent to Baixada Santista coast was studied in relation to the environmental factors. Twenty-one stations were sampled in August and September 2005 (Winter) and February 2006 (Summer), on board of R/V "Prof. W. Besnard" as part of the interdisciplinary project "ECOSAN". The samples were obtained with a $0.09 \mathrm{~m}^{2}$ box corer in duplicate. Species composition and the community variables (density, biomass, diversity and eveness) were determinated. The environmental parameters obtained were depth, temperature, salinity, granulometry, organic matter and carbonate content of the sediment. Cluster, n-MDS, Similarity and BIO-Env analyses were performed to interpret the results. Fourty one species and nineteen morfospecies were found and classified in twenty four families for both campaigns. Summer presented the highest abundance and few species were dominant. Ampelisca paria, Metharpinia sp.n., Microphoxus moaresi, Urothoe sp.n., Gitanopsis sp. and Photis brevipes were dominant in all sampled periods. Diversity and density were low in the stations near to the mouth of Baía de Santos and southwards, in front of Peruíbe. Both ordination and similarity analyses showed the shelf divided in four distinct areas in winter and four in summer, based in the species composition and influenced by depth. It was found a typical community in the coastal zone, other in the outer shelf and another sharing species with both zones. The vertical faunal distribution pointed a decrease in density and diversity with the increase in depth of the sedimentary column. Same stations of the intermediary and deep group showed a less abrupt decrease in density and richness in relation to the shallow stations. In general, each stratum were characterized by a different species.
\end{abstract}

Key words: Amphipoda, macrofauna, continental shelf, Baixada Santista. 


\section{INTRODUÇÃO}

Os anfípodes são extremamente comuns e amplamente distribuídos tanto nas regiões tropicais quanto nas temperadas e polares. Esses organismos constituem um dos mais importantes táxons da comunidade bentônica em relação à abundância, biomassa e diversidade, podendo, em alguns casos, ser altamente dominantes nas comunidades do macrobentos (BACHELET et al., 2003; YU et al., 2003).

Os anfípodes são heterogêneos em relação ao ciclo de vida e estratégias de alimentação das espécies (BIERNBAUM, 1979; JACOBI, 1987). Muitos anfípodes bentônicos têm sido apontados como espécies-chave na estruturação de comunidades, excluindo membros de outros táxons por predação de larvas assentadas tanto no fundo quanto sobre os organismos adultos; podem ainda modificar a estabilidade do sedimento e o espaço útil disponível para os organismos cavadores e, em alguns casos, competir por uma maior eficiência na assimilação de alimento (GRANT, 1981a, b; OLIVER \& SLATTERY, 1985; CONLAN, 1994). Os anfípodes influenciam tanto as comunidades da macrofauna como da meiofauna. Há relatos na literatura sobre as abundâncias de copépodes harpacticoides e de turbelários serem relacionadas positivamente ao incremento do número de anfípodes, devido a uma maior disponibilidade de alimento proveniente tanto da bioturbação, quanto do aumento de anfípodes mortos (OLIVER et al., 1982; OLAFSSON \& ELMGREN, 1991; THOMAS, 1993; CONLAN, 1994; BACHELET et al., 2003).

Além de consumidores os anfípodes exercem um papel importante na cadeia alimentar marinha, compondo a dieta de poliquetos, nemertíneos, crustáceos, e de peixes, pássaros e mamíferos que se alimentam de organismos bentônicos (WAKABARA et al., 1982; CONLAN, 1994; THIEL, 2000; PALMA \& OJEDA, 2002; THIEL et al., 2003). Muitos desses predadores podem alterar a composição populacional dos anfípodes de um local através da seletividade do tamanho e sexo de suas presas (CONLAN, 1994). Os adultos, principalmente os machos, são intensamente predados devido a sua grande visibilidade e maior atividade de natação no período de acasalamento (OLIVER \& SLATTERY, 1985; CONLAN, 1994). Na fase juvenil os anfípodes podem ser negligenciados em virtude do seu pequeno tamanho e, sendo Peracarida, ao cuidado parental prolongado que lhes é fornecido após deixarem o marsúpio (THIEL, 1997; 1999a, b; THIEL et al., 1997; 2003).

De forma geral, apesar de sua expressiva densidade, a diversidade de anfípodes é pouco conhecida, exceto em algumas regiões do mundo extensivamente estudadas, tais como Atlântico Norte, Mediterrâneo, Noroeste do Pacifíco e Austrália (SOUZA-FILHO, 2007). Especialmente em regiões tropicais a diversidade de anfípodes é pouco estudada quando comparada com a de regiões temperadas e de altas latitudes, devido ao grande 
número de espécies presentes e a escassez de trabalhos de sistemática e ecologia (Barnard, 1991; THOMAS, 1993).

Em várias partes do mundo a análise da estrutura da comunidade da macrofauna bentônica tem sido uma importante ferramenta em programas de monitoramento, porque tal fauna é caracterizada por uma mobilidade restrita, ficando sujeita às condições ambientais vigentes, tais como granulometria do sedimento e disponibilidade de alimento (POSEY, 1987; SOLA \& PAIVA, 2001). Dentro da macrofauna bentônica os crustáceos, e principalmente os anfípodes, despertam grande interesse sob o ponto de vista ecológico, podendo ser utilizados como indicadores de biodiversidade e de mudanças ambientais causadas por perturbações naturais ou antropogênicas (THOMAS, 1993; CONLAN, 1994; THIEL et al., 2003).

Os anfípodes formam um grupo particularmente sensível, não somente ao estresse ambiental decorrente do aumento do teor de matéria orgânica, mas também ao aumento de distintos outros tipos de poluentes incluindo metais e hidrocarbonetos derivados do petróleo (DAUVIN, 1998). Muitas famílias, tais como Ampeliscidae, Pontoporeidae, Melitidae e Gammaridae, são amplamente afetadas por estes últimos e podem desaparecer diante de um derramamento de óleo (DAUVIN, 1998; 2000; CORREIA et al., 2002; DAUVIN \& RUELLET, 2007).

Os anfípodes têm sido utilizados em bioensaios para uma ampla escala de toxinas, tanto como bioindicadores ambientais, quanto como organismos para testes laboratoriais de toxicidade. Destaca-se por exemplo, a espécie Tiburonella viscana (Platyischnopidae) (LU \& WU, 2006; HEUVEL-GREVE et al., 2007; VIGANO et al., 2007; MASSAMBA-N'SIALA et al. 2008) amplamente utilizada em estudos de toxicidade na costa brasileira (ABESSA et al., 2005; CESAR et al., 2007; CHOUERI et al., 2009). Espécies tubícolas e cavadoras são as mais utilizadas em bioensaios de poluição e como indicadoras de mudanças ambientais em conseqüência da sua alta especificidade ao habitat e sua baixa mobilidade (CONLAN, 1994; CASADO-MARTINEZ et al., 2007; CESAR et al., 2007; MELO \& NIPPER, 2007). Nos últimos anos, além de testes de toxicidade, estudos com biomarcadores estão sendo desenvolvidos com algumas espécies de anfípodes, objetivando avaliar a sensibilidade e o período de recuperação dos organismos para determinadas toxinas (CORREIA et al., 2002).

O oceano tropical compreende $50 \%$ da área total de águas oceânicas globais e 30\% da área total das plataformas continentais. A largura e profundidade das plataformas é basicamente fruto da atividade tectônica, que as tornam mais largas ao longo das margens continentais passivas, como é o caso do Atlântico Ocidental. Sua morfologia e grau de 
desenvolvimento podem ser ainda profundamente afetados pela descarga dos grandes rios (LONGHURST \& PAULY, 1987).

A plataforma continental brasileira tem aproximadamente $820.000 \mathrm{~km}^{2}$ de comprimento (YESAKI, 1974). A Margem Continental Sul (de Vitória/ES até o sul do Brasil) possui um espesso pacote de sedimentos terrígenos, e a deposição deste material ao longo dos tempos resultou em uma plataforma larga e com suave transição para o talude, sendo a largura variável entre aproximadamente de 20 e $250 \mathrm{~km}$ nas regiões Sul e Sudeste (ZEMBRUSKI, 1979).

O ecossistema da plataforma continental brasileira da região sudeste - sul (desde Cabo Frio/RJ até o cabo de Santa Marta/SC) é uma unidade dinâmica sob o ponto de vista oceanográfico, pois nele atuam diferentes massas de água (PIRES-VANIN, 2008). As características termohalinas dessas massas apresentam amplitudes significativas de variação, sobretudo em função da sazonalidade. As intrusões ortogonais da Água Central do Atlântico Sul (ACAS) sobre a plataforma em direção à costa são certamente a principal fonte de nutrientes inorgânicos, fertilizando em grande escala a base da zona eufótica de plataforma continental externa no inverno e plataforma interna e média no verão, ocasião esta com a maior incidência de ventos nordeste (AIDAR et al., 1993; BRANDINI, 2006). A intrusão da ACAS faz com que a estrutura física da coluna de água exerça uma influência considerável sobre a natureza do substrato bentônico, afetando em maior ou menor grau os organismos que aí vivem e alterando, assim, a densidade, biomassa e diversidade das comunidades (PIRES-VANIN, 1993; 2008).

A plataforma continental não é sedimentarmente homogênea, apresentando tanto regiões com predominância de sedimentos finos quanto regiões arenosas. 0 litoral sul do Estado de São Paulo é caracterizado por mosaicos de areia fina e silte, enquanto a plataforma ao largo de Santos exibe uma predominância de areias média e fina. Conseqüentemente a distribuição dos organismos bentônicos não é uniforme, apresentando-se em manchas. Na plataforma continental as áreas arenosas são geralmente colonizadas por um maior número de espécies, e são habitats para muitos organismos da macrofauna (exemplo poliquetos, bivalves e anfípodes) com diversidade de espécies e densidade comparáveis a de regiões entremarés (LANA et al., 1996; BROOKS et al., 2006).

A macrofauna bentônica da plataforma sudeste é composta por uma grande densidade e diversidade de invertebrados e compreende tanto organismos da infauna quanto da epifauna. Possui representantes de quase todos os filos de invertebrados, sendo predominantes os anelídeos poliquetos, moluscos e crustáceos (PIRES-VANIN, 1992; 
1993; 2008; PIRES-VANIN et al., 1997). Dentre estes últimos destacam-se os Peracarida representados no ambiente marinho pelos misidáceos, cumáceos, tanaidáceos, isópodes e anfípodes. Apesar de seu pequeno tamanho, especialmente anfípodes e isópodes são muito abundantes e amplamente distribuídos no meio marinho, água doce e também no ambiente terrestre (OLIVER et al., 1982).

No Brasil, trabalhos sobre a macrofauna bentônica na plataforma continental brasileira foram mais intensificados na região sudeste, principalmente no litoral do Estado de São Paulo e em especial na região de Ubatuba e São Sebastião. Tais estudos são tanto de cunho qualitativo quanto quantitativo (PAIVA, 1993a, b; PIRES-VANIN, 1993; 2008; PIRES-VANIN et al., 1997; SUMIDA \& PIRES-VANIN, 1997; FLYNN et al., 1999; MUNIZ \& PIRES-VANIN, 2000; VENTURINI, 2007), e também compreendem aqueles que visaram avaliar os possíveis impactos de poluentes advindos do porto de São Sebastião, localizado no Canal de mesmo nome (BÍCEGO et al., 2006; PIRES-VANIN et al., 2006 a, b). Conseqüentemente, o conhecimento sobre a composição e distribuição de Peracarida na plataforma continental brasileira é proveniente desses locais (WAKABARA, 1969; VALÉRIO-BERARDO, 1992; MIYAGI, 2000; VALÉRIO-BERARDO et al., 2000a, b, c; SANTOS \& PIRES-VANIN, 2000).

Contudo, importantes estudos relacionados com a ecologia de anfípodes na plataforma continental podem ser encontrados em outras regiões do Brasil, tais como o de Gallerani (1997), realizado na Bacia de Campos, RJ; Capitoli \& Bemvenuti (2004), que estudaram a macrofauna total na região sul, da desembocadura da Lagoa dos Patos até o talude continental; Calil (2005), que estudou a comunidade de decápodes e anfípodes para a Baía de Sepetiba - RJ; e Souza-Filho (2007), cujo estudo foi realizado dentro do Programa REVIZEE-NE e que também contribuiu com dados importantes para o conhecimento da comunidade dos Bancos Oceânicos da Cadeia Norte, de Fernando de Noronha e da plataforma continental no nordeste do Brasil.

Recentemente o interesse científico tem se voltado para o entendimento do papel que os emissários submarinos presentes na região da Baixada Santista exercem sobre a biota, verificando se estes podem mudar a composição química e granulométrica do local e se são fonte de poluentes para o ecossistema marinho da região. Nesses trabalhos, além do uso de análises químicas pertinentes, bioensaios de toxicidade com anfípodes têm sido utilizados com sucesso (ABESSA et al., 2005; MELO \& NIPPER, 2007; MARTINS et al., 2008).

Dentro dessa linha de interesse, no sentido de se avaliar a influência do complexo estuarino da Baixada Santista sobre a Plataforma Continental Adjacente, situada entre São 
Sebastião e Peruíbe, foi idealizado um projeto interdisciplinar intitulado "A influência do complexo estuarino da Baixada Santista sobre o ecossistema da Plataforma Adjacente" ECOSAN. Este projeto inicou em 2004 e terminou em 2008, tendo sido financiado pela FAPESP e CNPq, dentro do Programa PRONEX (Processo: 2003/09932-1). 0 objetivo geral do ECOSAN foi estudar o aporte do material orgânico e inorgânico nessa região da plataforma, bem como os mecanismos físicos que possibilitam sua entrada e deposição, e as alterações que causam sobre os processos biológicos e a estrutura do ecossistema da área (PIRES-VANIN, 2005). 


\section{OBJETIVOS}

O objetivo geral do presente trabalho é de estudar a estrutura, composição e distribuição dos Amphipoda da Plataforma Continental Interna e Média entre São Sebastião e Peruíbe, e identificar quais os fatores que influenciam essa distribuição. Conseqüentemente, o estudo visou verificar se o processo oceanográfico dominante na área, que é a entrada sazonal da Água Central do Atlântico Sul (ACAS), influencia a dinâmica da comunidade de anfípodes nessa área.

O presente trabalho, inserido no subprojeto Bentos, dentro do projeto ECOSAN, visa em primeiro lugar incrementar o conhecimento sobre a composição e distribuição dos Amphipoda na plataforma continental sudeste brasileira, acrescentando informações sobre a porção correspondente à Baixada Santista. Em segundo lugar este trabalho pretende avaliar quais são os parâmetros responsáveis pela estruturação e distribuição das comunidades de Amphipoda numa área sob possível influência antrópica, contribuindo assim, para o entendimento do papel destes organismo na estruturação do ecossistema local.

Para o alcance desses objetivos estudaram-se os seguintes descritores biológicos da comunidade: densidade, diversidade, riqueza de espécies, eqüitatividade, freqüência de ocorrência, e sua relação com as variáveis ambientais mensuradas: temperatura, salinidade, granulometria, matéria orgânica e carbonato, em duas épocas distintas quanto à presença da ACAS na região, inverno e verão. Esperou-se encontrar uma estrutura diferencial das comunidades de anfípodes na área, correlacionada à época do ano e a uma possível variação sedimentar local na plataforma predominantemente arenosa. 


\section{CARACTERIZAÇÃO DA ÁREA DE ESTUDO}

\subsection{Características gerais - plataforma continental sudeste-sul brasileira e Baixada Santista}

A plataforma continental sudeste-sul brasileira estende-se desde a área ao sul do Embaiamento de Tubarão (ES-Brasil) até a fronteira com o Uruguai, entre as latitudes $19^{\circ}$ S e $38^{\circ}$ S. $O$ setor denominado de Embaiamento de São Paulo (ZEMBRUSKI, 1979), ou de margem sudoeste, ou costa sudoeste (CÔRREA \& VILLWOCK, 1996; MAHIQUES, 1998) estende-se de Cabo Frio até Florianópolis, apresentando uma largura variável de 73 a 231 $\mathrm{km}$ e declividade entre 1:656 e 1:333. Na região entre a Ilha de São Sebastião e Florianópolis a plataforma continental alarga-se e as isóbatas tornam-se mais estreitas a partir dos 200 m (CÔRREA \& VILLWOCK, 1996).

A área estudada situa-se na plataforma continental sudeste entre São Sebastião e Peruíbe, no estado de São Paulo. Possui um importante sistema fluvial, que na região da Baixada Santista, é composto por uma série de rios que desembocam nos canais de Santos e São Vicente e esses, por sua vez, na baía de Santos. No litoral sul, os rios Peruíbe (e o sistema Cananéia- Iguape) e o Rio Itanháem contribuem com importante volume de água para os ecossistemas estuarinos da região.

A Baixada Santista ocupa uma posição central na costa paulista, ao entremear o Litoral Norte, caracterizado por costas altas, extremamente recortadas, com inúmeras enseadas, ilhas e cabos, e o Litoral Sul, dominantemente retilíneo com costas baixas, extensas e monótonas (PENTEADO, 1965). Este setor do litoral de São Paulo apresenta, basicamente, duas formações geológicas principais: a área da escarpa da Serra do Mar e a planície sedimentar litorânea. Em frente à serra e circundando os morros e maciços isolados, desenvolve-se a planície sedimentar formada originalmente por aluviões, material de mangues atuais e antigos e por sedimentos de praias em geral (RODRIGUES, 1965).

A região apresenta características climáticas bastante individualizadas, sob domínio alternado dos sistemas tropical e polar atlântico, podendo ser classificado como clima quente e úmido, com temperatura máxima absoluta de $39^{\circ} \mathrm{C}$ e mínima absoluta de $10^{\circ} \mathrm{C}$, e com temperatura média anual de $22^{\circ} \mathrm{C}$. A temperatura média no mês mais quente (fevereiro) é superior a $25^{\circ} \mathrm{C}$ e a média no mês mais frio (julho) é acima de $18^{\circ} \mathrm{C}$. Trata-se de uma região chuvosa, com valores mensais de precipitação acima de $100 \mathrm{~mm}$ durante todo o ano. A precipitação é maior no verão (janeiro-março), decrescendo no inverno (julho-agosto). A região não apresenta uma estação seca definida, com precipitação média 
anual entre 2000 e $2500 \mathrm{~mm}$. A umidade relativa do ar é alta, alcançando cerca de $80 \%$ durante o ano (MENGHINI, 2004).

Do ponto de vista oceanográfico, um mecanismo que contribui para a estruturação de uma termoclina na costa sudeste-sul do Brasil é a variação sazonal da direção e intensidade dos ventos. Durante o verão, a direção predominante passa a pertencer ao primeiro quadrante (E-N), com o componente paralelo à costa soprando de nordeste para sudoeste. Durante o inverno, a direção predominante dos ventos pertence ao terceiro quadrante (W-S), que também apresenta um paralelo à costa que sopra de sudoeste para nordeste (BRAGA \& NIENCHESKI, 2006). Como ocorre em todo o litoral sudeste-sul do Brasil a região está sujeita à constante ação das massas de ar e das perturbações frontais que freqüentemente atuam na região (SANTOS, 1965; SCHAEFFER-NOVELLI, 1986).

Santos abriga alguns dos mais antigos núcleos urbanos do Brasil, incluindo a primeira vila do país, a Vila de São Vicente, fundada em 1532. Desde então, a região vem sendo ocupada, muitas vezes de maneira desorganizada, gerando inúmeros problemas ambientais e de saúde pública ao longo do tempo; mas, somente a partir da segunda metade do século XX é que esse processo de ocupação se intensificou, com a expansão do Porto de Santos, a instalação do pólo industrial de Cubatão e o aumento do turismo (ABESSA, 2002).

A região da Baixada Santista, com sua configuração particular da costa, tem o esgoto urbano como uma das mais importantes fontes de poluição marinha e estuarina do Brasil. Um programa de saneamento foi conduzido entre anos 70 e 90, e envolveu a construção de sistemas de coleta em algumas cidades e a instalação de quatro emissários submarinos ao longo da costa. 0 seu principal e mais antigo emissário, operante desde 1978 em Santos e servindo para as cidades de Santos e São Vicente, descarta esgoto não tratado no oceano, e deve ser considerado como uma fonte significativa de contaminação para a Baía de Santos e possivelmente para a plataforma continental adjacente (ABESSA et al., 2005; MARTINS et al., 2008). 


\subsection{Hidrografia e sedimento da região}

Castro (1996), baseado na dinâmica das massas de água, sugere uma divisão da plataforma continental sudeste em três regiões: interna, média e externa. Essas regiões possuem características físicas diferentes, conforme descrito a seguir.

Sob o ponto de vista hidrológico, a Plataforma Continental Interna (PCI) localiza-se entre a costa e a Frente Térmica Profunda (FTP) e sua principal característica é apresentar durante todo ano grande tendência à homogeneidade tridimensional das propriedades físicas (temperatura, salinidade e pressão). Assim, durante o verão, as água da PCI são em geral mais quentes, mais salinas e menos densas do que o inverno (CASTRO et al., 2006; 2008).

A Plataforma Continental Média (PCM), localizada entre a FTP e a Frente Halina Superficial (FHS), é mais nítida no verão, quando apresenta grande estratificação da coluna de água devido à presença de uma aguda termoclina sazonal; no inverno fica em dimensões reduzidas, devido o recuo da ACAS sendo limitada pela isóbata de $100 \mathrm{~m}$ (Castro et al, 2006). A Plataforma Continental Externa (PCE) prolonga-se desde a FHS, ou do limite externo da PCM, até a quebra da plataforma continental. A PCE também apresenta estratificação vertical acentuada e pequena variação sazonal das propriedades físicas (CASTRO et al, 2006, 2008).

A Corrente do Brasil (CB), no seu local natural de ocorrência sobre o talude continental ao largo da plataforma continental sudeste-sul, transporta massas de água de origens distintas: a Água Tropical (AT), na camada superficial, e a Água Central do Atlântico Sul (ACAS), logo abaixo (CASTRO et al., 2006). Essas duas massas de água penetram a plataforma continental sudeste-sul através de diferentes mecanismos e o resultado da mistura com as águas presentes na parte mais interna, que têm tipicamente baixa salinidade devido ao aporte continental, é uma terceira massa de água, denominada Água Costeira (AC). Consequentemente, três massas de água e produtos de suas misturas ocupam a plataforma continental sudeste- sul: a AC, caracterizada por baixas salinidades banhando a costa e, nas proximidades da quebra da plataforma continental, ocorre uma estratificação vertical com a AT, relativamente quente e salina na camada superficial e a ACAS, mais fria e menos salina, na camada de fundo (CASTRO et al., 1987, 2006, 2008; CASTRO \& MIRANDA, 1998).

A PCI é ocupada pela AC, que tende a ser verticalmente homogênea, devido aos processos de mistura causados pelo vento e correntes de maré. A formação de uma frente térmica de fundo separa hidrologicamente a PCI da PCM (CASTRO et al., 2006). A posição 
da frente térmica muda sazonalmente, estando mais próxima da costa no verão e mais afastada no inverno (CONTI, 2004; BRAGA \& NIENCHESKI, 2006). Durante os meses de primavera e verão, ocorre a ingressão da ACAS pelo fundo em direção à plataforma interna, sendo que esta intrusão ocasiona a saída da AC na superfície. Durante o inverno a ACAS situa-se afastada da costa, conferindo a PCI uma condição mais homogênea e dominada pela AC (CASTRO et al., 1987). As águas da PCM mostram uma estrutura em duas camadas, especialmente no verão, quando uma estreita e rasa termoclina fica evidenciada próxima aos limites da PCI. As águas da camada de fundo, nessa situação, são identificadas como pertencentes à ACAS (CONTI, 2004). Verão e inverno são, pois, duas situações oceanograficamente distintas, e que conduzem a ocupações diferenciais do fundo pelos diversos organismos bentônicos componentes do sistema (PIRES-VANIN, 2008).

Furtado \& Mahiques (1990) e Mahiques et al. (1999) estudaram as características morfológicas e sedimentares da plataforma continental sudeste e concluíram que o fundo é constituído predominantemente por areias finas e muito finas. Em outro trabalho, Mahiques et al. (2004) observaram que esta característica sedimentar está relacionada com a forte dinâmica das três massas de águas presentes, sua circulação na plataforma e também com a ausência de um aporte considerável de água doce.

Muitos trabalhos comprovaram que a área da Ilha de São Sebastião (ISS) marca o limite entre duas principais zonas sedimentares, que se diferenciam tanto por sua distribuição e composição quanto pelas diferenças entre as frações orgânicas e inorgânicas presentes no sedimento (ROCHA et al., 1975; KOWSMANN \& COSTA, 1979; MARTINS \& CORRÊA, 1996; MAHIQUES et al., 1999, 2004). Na região ao norte da ISS, uma mistura de diferentes tamanhos de grãos é observada com significante deposição de lama na plataforma interna. Ao sul da ISS as PCI e PCM são caracterizadas pela predominância de areia fina a muito fina, sedimento bem selecionado e manchas isoladas de silte. Neste setor um aumento gradual de lama ocorre em direção à PCE (MAHIQUES et al., 1999; 2004; CONTI, 2004).

Os parâmetros texturais do sedimento de fundo distribuem-se segundo uma tendência de diminuição no tamanho dos grãos e no grau de seleção da costa em direção a regiões de maiores profundidades. A maior parte da plataforma interna e média é fundamentalmente composta por material arenoso com teores de carbonato variando em torno de 0 a $25 \%$ (CONTI, 2004).

Segundo Mahiques et al. (1999) ao sul da Ilha de São Sebastião a ausência de grandes modificações no relevo submarino levam a maiores efeitos das ações de ondas na 
plataforma interna, dificultando o depósito de sedimentos lamosos e, conseqüentemente, de matéria orgânica. Isto leva a ocorrência de um gradiente do conteúdo de matéria orgânica através da quebra da plataforma.

A proximidade da plataforma interna com o sistema estuarino de Santos - São Vicente contribui fortemente para o padrão granulométrico encontrado para essa região. Devido ao grande aporte sedimentar que adentra o baixo estuário, o Canal do porto de Santos necessita de dragagem permanente. Todo o material dragado do porto é disposto ao sul da Ilha da Moela pelos batelões da CODESP (Companhia Docas do Estado de São Paulo). Até o início da década de 80, os sedimentos eram dispostos nas proximidades da Ponta da Manduba, na Ilha de Santo Amaro, mas parte do material retornava às praias. Ambas as áreas estão localizadas na transição entre a área externa da Baía de Santos e início da plataforma continental interna. Desta forma, a plataforma adjacente atua como receptáculo de parte do material dragado do Canal do porto, podendo retornar à baía devido à hidrodinâmica da região (FERREIRA, 2008). Segundo a mesma autora esses contaminantes contidos no material dragado do Porto de Santos apresentam grande potencial para influenciar a fauna presente nas proximidades da Ilha da Moela. 


\section{MATERIAL \& MÉTODOS}

\subsection{Trabalho de campo}

Dois cruzeiros oceanográficos foram realizados na plataforma continental entre São Sebastião e Peruíbe ( $23^{\circ} 50^{\prime} \mathrm{S}$ a $2^{\circ} 23^{\prime} \mathrm{S}$ e $45^{\circ} 12^{\prime} \mathrm{W}$ a $46^{\circ} 54^{\prime} \mathrm{W}$ ), à bordo do N/Oc. "Prof. W. Besnard", entre 26 de agosto a 04 de setembro de 2005 (campanha de inverno) e de 13 a 22 de fevereiro de 2006 (campanha de verão). Foram coletadas amostras em 21 estações, posicionadas através de GPS (“Global Positioning System”) (Figura 1 e Tabela 1). Para a caracterização abiótica de cada estação, medidas de temperatura, salinidade e profundidade foram obtidas por meio de CTD ("Condutivity, Temperature, Depth" - Marca SeaBird, modelo MCTD-MBP-S) (Figura 2A).

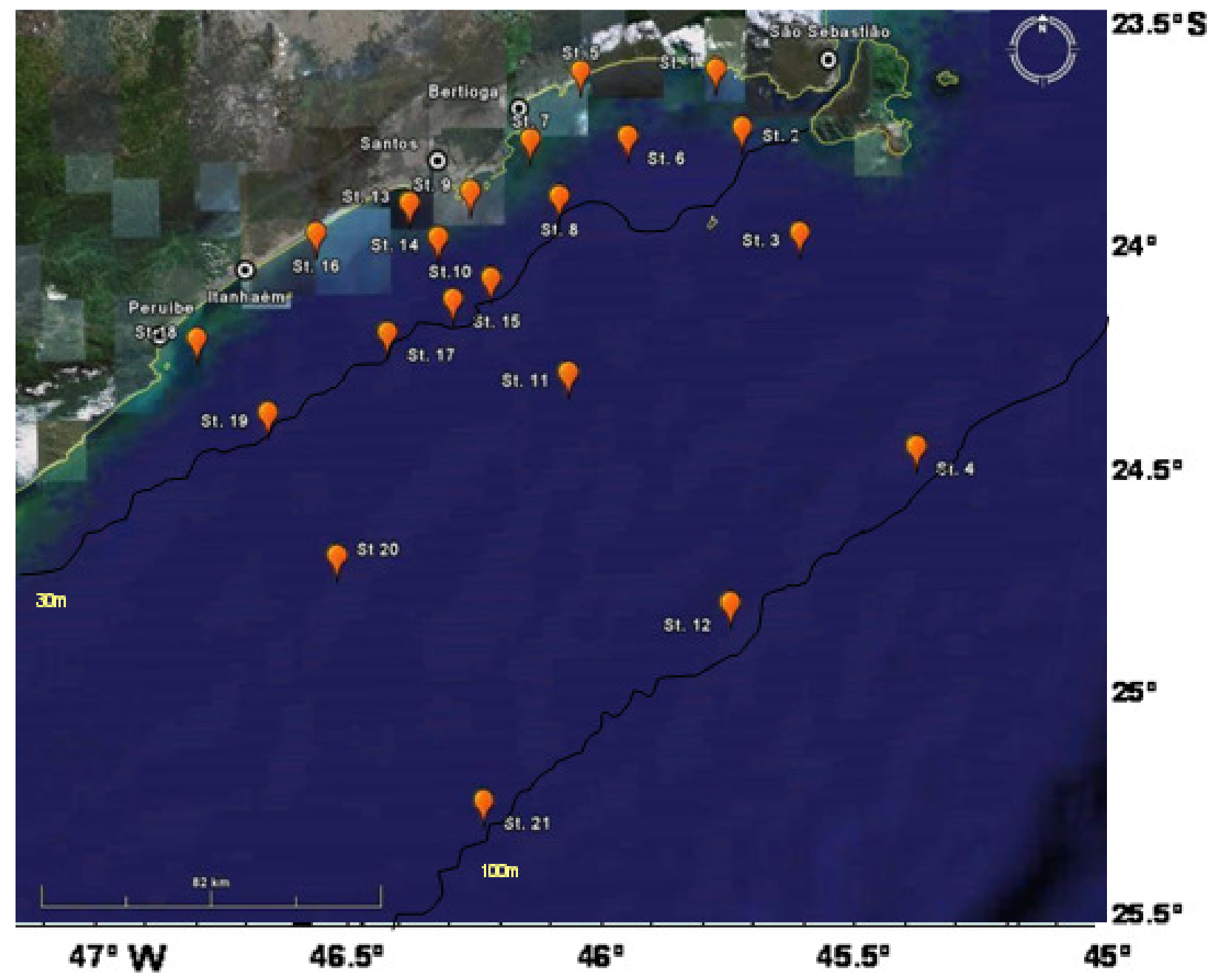

Figura 1 - Área de estudo com a malha amostral. (Fonte Google Earth: htttp:// earth.google.com) 
Tabela 1 - Coordenadas geográficas das estações amostradas na plataforma continental entre São Sebastião e Peruíbe, SP, no período de 26 de agosto a 4 de setembro de 2005 (inverno) e 13 a 22 de fevereiro de 2006 (verão).

\begin{tabular}{|c|c|c|c|c|}
\hline \multirow{2}{*}{ Estações } & \multicolumn{2}{|c|}{ Inverno /2005 } & \multicolumn{2}{|c|}{ Verão /2006 } \\
\hline & Latitude (S) & Longitude (W) & Latitude (S) & Longitude (W) \\
\hline 1 & $23^{\circ} 50^{\prime} .16$ & $045^{\circ} 41^{\prime} .52$ & $23^{\circ} 50^{\prime} .13$ & $045^{\circ} 41^{\prime} .47$ \\
\hline 2 & $23^{\circ}=56^{\prime} .82$ & $045^{\circ} 37^{\prime} .20$ & $23^{\circ} 56^{\prime} .82$ & $045^{\circ} 37^{\prime} .20$ \\
\hline 3 & $24^{\circ}=10^{\prime} .32$ & $045^{\circ} 29^{\prime} .10$ & $24^{\circ}=10^{\prime} .32$ & $045^{\circ} 29^{\prime} .10$ \\
\hline 4 & $24^{\circ}=37^{\prime} .62$ & $045^{\circ} 12^{\prime} .84$ & $24^{\circ}-37^{\prime} .70$ & $045^{\circ} 12^{\prime} .88$ \\
\hline 5 & $23^{\circ} 50^{\prime} .16$ & $045^{\circ} 59^{\prime} .46$ & $23^{\circ} 50^{\prime} .16$ & $045^{\circ} 59^{\prime} .46$ \\
\hline 6 & $23^{\circ} 5^{\prime \prime} .58$ & $045^{\circ} 53^{\prime} .94$ & $23^{\circ} 59^{\prime} .58$ & $045^{\circ} 53^{\prime} .94$ \\
\hline 7 & $24^{\circ} 00^{\prime} .01$ & $046^{\circ} 06^{\prime} .05$ & $24^{\circ}=00^{\prime} .00$ & $046^{\circ} 06^{\prime} .00$ \\
\hline 8 & $24^{\circ}=04^{\prime} .62$ & $046^{\circ} 03^{\prime} .12$ & $24^{\circ}=04^{\prime} .61$ & $046^{\circ} 03^{\prime} .08$ \\
\hline 9 & $24^{\circ} 05^{\prime} .10$ & $046^{\circ} 15^{\prime} .24$ & $24^{\circ}=05^{\prime} .07$ & $046^{\circ} 15^{\prime} .25$ \\
\hline 10 & $24^{\circ}=09^{\prime} .97$ & $046^{\circ} 12^{\prime} .51$ & $24^{\circ} 09^{\prime} .90$ & $046^{\circ} 12^{\prime} .48$ \\
\hline 11 & $24^{\circ}=27^{\prime} .66$ & $046^{\circ} 02^{\prime} .04$ & $24^{\circ}=27^{\prime} .60$ & $046^{\circ} 02^{\prime} .02$ \\
\hline 12 & $25^{\circ} 02^{\prime} .14$ & $045^{\circ} 41^{\prime} .65$ & $25^{\circ} 02^{\prime} .16$ & $045^{\circ} 41^{\prime} .64$ \\
\hline 13 & $24^{\circ} 03^{\prime} .96$ & $046^{\circ} 22^{\prime} .38$ & $24^{\circ} 03^{\prime} .96$ & $046^{\circ} 22^{\prime}, 38$ \\
\hline 14 & $24^{\circ}=07^{\prime} .68$ & $046^{\circ} 20^{\prime} .04$ & $24^{\circ} 00^{\prime} .68$ & $046^{\circ} 20^{\prime} .04$ \\
\hline 15 & $24^{\circ}=12^{\prime} .54$ & $046^{\circ}-17^{\prime} .22$ & $24^{\circ}=12^{\prime} .74$ & $046=17^{\prime} .09$ \\
\hline 16 & $24^{\circ}=10^{\prime} .17$ & $046^{\circ} 37^{\prime} .08$ & $24^{\circ}=10^{\prime} .13$ & $046^{\circ} 37^{\prime} .03$ \\
\hline 17 & $24^{\circ}=20^{\prime} .28$ & $046^{\circ} 31^{\prime} .08$ & $24^{\circ}=20^{\prime} .28$ & $046^{\circ} 31^{\prime} .08$ \\
\hline 18 & $24^{\circ}=21^{\prime} .87$ & $046^{\circ} 54^{\prime} .73$ & $24^{\circ}=21^{\prime} .95$ & $046^{\circ}=54^{\prime} .73$ \\
\hline 19 & $24^{\circ}=30^{\prime} .96$ & $046^{\circ} 4^{\prime} 9^{\prime} .68$ & $24^{\circ} 30^{\prime} .94$ & $046^{\circ} \quad 49^{\prime} .65$ \\
\hline 20 & $244^{\circ} 48^{\prime} .49$ & $046^{\circ} 39^{\prime} .02$ & $24^{\circ}=48^{\prime} .60$ & $046^{\circ} \quad 39^{\prime} .18$ \\
\hline 21 & 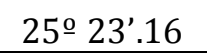 & $046^{\circ}=18^{\prime} .78$ & $25^{\circ} 23^{\prime} .11$ & $046^{\circ}=18^{\prime} .99$ \\
\hline
\end{tabular}

Embora a área de estudo tenha ampla variação batimétrica (10 a 100 metros), devido ao objetivo do Projeto ECOSAN de investigar o aporte de contaminantes provenientes da Baía de Santos para a plataforma adjacente, foi priorizada a amostragem na zona costeira, ou seja, um número maior de estações foi estabelecido até a isóbata de 30 metros (71\%), havendo um adensamento na desembocadura da baía.

Para o estudo quantitativo da fauna foi utilizado um "Box corer" de 0,09 $\mathrm{m}^{2} \mathrm{e}$ capacidade de 40 litros de sedimento (Figura 2B). Em cada estação o material foi coletado em duplicata; um terceiro lance foi utilizado para a caracterização sedimentar. Além disso, cada amostra foi dividida e coletada separadamente em três estratos, a saber: estrato de superfície (os primeiros 2,5 $\mathrm{cm}$ a partir da superfície do sedimento), estrato do meio (os $2,5 \mathrm{~cm}$ seguintes) e estrato inferior (10 $\mathrm{cm}$ restantes). Desta forma em cada cruzeiro foram obtidas 126 amostras (21 estações x 2 lances de "box corer" x 3 estratos), totalizando 252 amostras nos dois cruzeiros realizados (Figura 3). 

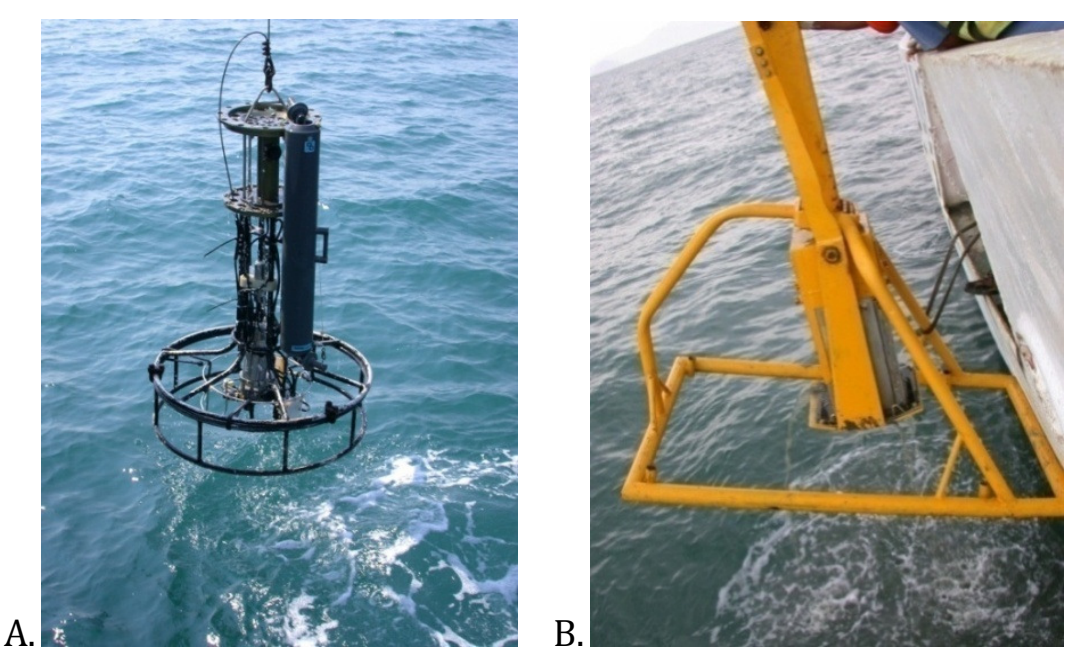

Figura 2- Aparelhos utilizados na coleta: A) CTD e B) Box Corer.

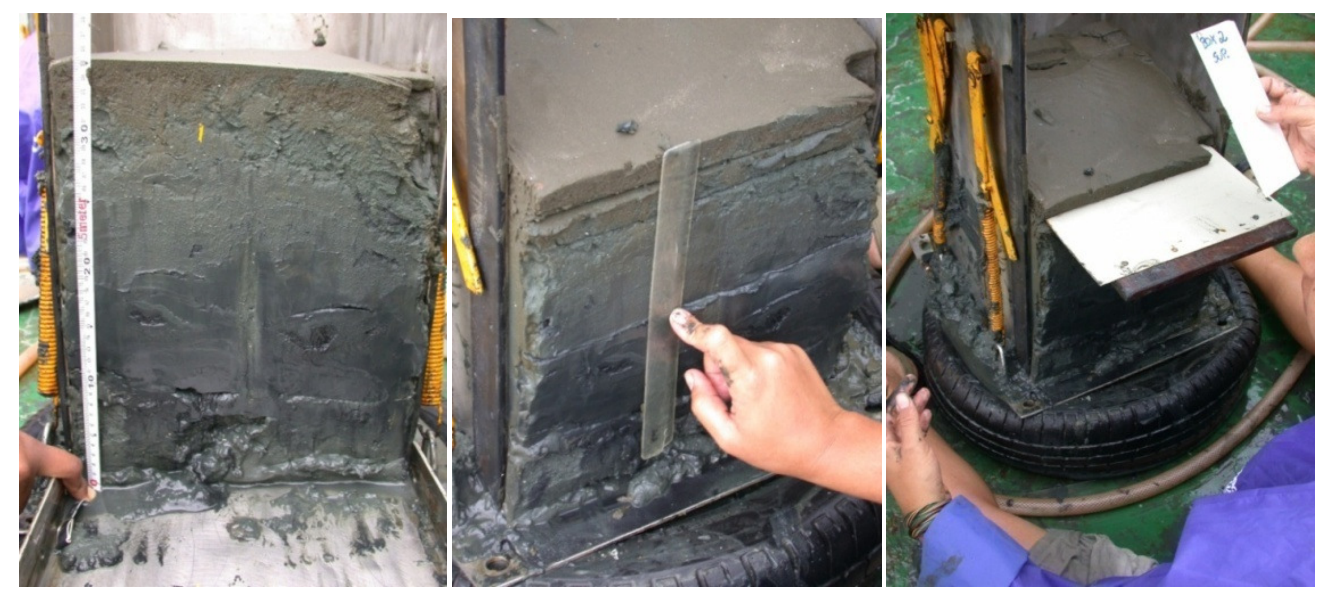

Figura 3 - Procedimento de amostragem dos três estratos (superfície, meio e inferior).

À bordo, as amostras de sedimento foram lavadas em um jogo de peneiras com malhagem de 1,0 e $0,5 \mathrm{~mm}$ para a separação da macrofauna. 0 material retido foi conservado em álcool 70\% e colocado em frascos plásticos devidamente etiquetados. Todo o material foi levado para o Laboratório de Ecologia Bêntica do IOUSP para processamento.

\subsection{Trabalho de laboratório}

No Laboratório de Ecologia Bêntica foi realizada a triagem da macrofauna, sob microscópio estereoscópico, separando-se e identificando-se a fauna em grandes grupos taxonômicos. Os anfípodes foram contados e conservados em álcool 70\% para posterior identificação das espécies.

Para a quantificação da biomassa da comunidade de anfípodes (em nível de Ordem) foi utilizado o peso úmido, e os animais foram pesados com o auxílio de uma 
balança digital semi-analítica com precisão de 0,1 mg. Previamente à pesagem o excesso de fixador foi retirado através da secagem dos indivíduos em papel filtro, durante o período de um minuto (WETZEL et al., 2005).

Finalmente, sob microscópio estereoscópico, o material foi identificado e recontado. A identificação foi realizada com o auxílio de bibliografia especializada (BARNARD \& KARAMAN, 1991; MYERS \& LOWRY, 2003) e de consultas a especialistas.

Em relação ao sedimento, foram efetuadas as análises granulométricas e a determinação dos teores de carbonato e de matéria orgânica total para todas as amostras coletadas durante as campanhas oceanográficas. Tais análises foram realizadas seguindo as técnicas de peneiramento e pipetagem descritas por Suguio (1973) para a obtenção dos parâmetros estatísticos de Folk \& Ward (1957). Os teores de carbonato foram obtidos através da diferença de peso de alíquotas das amostras de sedimento $(\sim 1 \mathrm{~g})$, antes e após o ataque com solução de $\mathrm{HCl}$ 10\% (método de dissolução ácida). Já as porcentagens de matéria orgânica total foram determinadas a partir da oxidação das amostras de sedimento com peróxido de hidrogênio pela diferença de peso antes e depois (GROSS, 1971).

\subsection{Tratamento dos dados}

Após a identificação das espécies os descritores quantitativos de comunidades foram determinados. Para cada estação amostrada foram calculadas a densidade e a biomassa média entre as duas réplicas. Os dados obtidos foram tratados e testados através de técnicas univariadas e multivariadas não paramétricas, uma vez que não apresentam uma distribuição normal.

Os cálculos de densidade para os dois tipos de distribuição (espacial - por estação e vertical- por estratos) foram feitos utilizando-se os valores médios entre as réplicas de cada estação. Foram calculadas para cada amostra a diversidade de espécies [H' $\left.\left(\log _{\mathrm{e}}\right)\right]$ por meio do índice de Shannon- Wiener (SHANNON \& WEAVER, 1949) e a Eqüitatividade (J') por meio do índice de Pielou (1975). Este índice expressa o grau de distribuição dos indivíduos entre as espécies, sendo considerados eqüitativos valores superiores a 0,5 (SOUZA-FILHO, 2007). A riqueza de espécies foi determinada (S), e expresso o número de espécies encontradas em cada estação.

Para verificar a existência de diferenças significativas na biomassa, diversidade, eqüitatividade e riqueza de espécies entre as duas campanhas foram realizados testes t de Mann-Whitney, conhecido também como teste U. 0 teste U é uma prova não-paramétrica destinada a comparar dois grupos independentes de tamanhos semelhantes ou desiguais. 
Este teste verifica se uma determinada diferença encontrada entre medidas de dois grupos é estatisticamente significativa, em nível de significância de $95 \%(\mathrm{p}=0,05)$ (AYRES et al., 2007).

As espécies identificadas foram classificadas segundo seu grupo funcional (ocupação, mobilidade e grupo trófico). Esta classificação foi feita com base em literatura pertinente, sendo que algumas espécies foram reunidas pelo gênero a que pertencem quando não foi possível identificá-las.

As espécies foram classificadas segundo a sua ocupação no substrato e sua mobilidade em: Tubícolas de infauna, organismos que constroem tubos na coluna sedimentar; Tubícolas de epifauna, organismos que constroem tubos sobre a superfície do sedimento, muitas vezes aproveitando-se de outros organismos para suporte, como hidrozoários e briozoários; Epifauna: organismos de vida livre que ficam sobre o sedimento, podendo ser sedentários; Infauna: organismos que conseguem se enterrar no sedimento, podendo construir túneis e Oportunista de tubos: organismos que não conseguem construir tubos (pela ausência de glândulas nos pereópodos), mas se aproveitam de tubos construídos por outros organismos, podendo viver a eles associados (modificado de VALÉRIO-BERARDO, 1992).

A classificação em grupos tróficos foi baseada em Biernbaum (1979), Dauby et al. (2001), De Broyer et al. (2003) e Yu et al. (2003). Um total de sete grupos tróficos foram descritos por estes autores: Suspensívoro (S); Detritívoro de subsuperfície (DS); Detritívoro Cavador (DC); Necrofágo (N); Carnívoro (C); Comensal (Co) e Herbívoro (H). Entretanto, como as espécies têm a capacidade de mudar sua estratégia alimentar devido a mudanças nas condições ambientais, algumas foram classificadas em mais de uma categoria. Não foi possível classificar a espécie Kamakidae cf. Aorcho em um grupo trófico, devido a ausência de trabalhos sobre a espécie.

A freqüência de ocorrência das diferentes espécies foi determinada a partir da porcentagem de ocorrência de uma espécie em relação ao total de estações de coleta. Em seguida, as espécies foram classificadas em cinco categorias: Muito freqüente (MF - $\geq$ $30 \%$ ); Freqüente (F - $\geq 20-<30 \%)$; Pouco freqüente (PF - $\geq 10-<20 \%$ ); Rara (R - $\geq 5-<$ 10\%) e Muito rara (MR - <5\%) (VALÉRIO-BERARDO, 1992; MARQUES \& BELLANSANTINI, 1993).

No presente estudo as espécies foram classificadas em diferentes faixas batimétricas com o intuito de avaliar os dados de levantamento dos limites de distribuição 
dos anfípodes na costa brasileira obtidos por outros autores (WAKABARA, et al., 1991; VALÉRIO-BERARDO, 1992; GALLERANI, 1997 e SANTOS \& PIRES-VANIN, 2000).

Uma correlação não paramétrica foi realizada entre os dados de densidade de anfípodes, meiofauna e os dados abióticos, com o intuito de observar possíveis interrelações. Os dados de densidade da meiofauna aqui utilizados foram cedidos pela Prof $\stackrel{\text { a }}{ }$. Dr. - Thaïs Navajas Corbisier, do laboratório de Ecologia do Meiobentos do IOUSP, fazendo parte do projeto de mestrado da aluna Luciana Erika Yaginuma.

Os valores de densidade das espécies de anfípodes sofreram transformação por raiz quarta para todas as análises multivariadas. Escolheu-se esta redução por ser uma transformação mais severa do que a raiz quadrada, baixando a ponderação na importância das espécies mais abundantes e permitindo não somente às espécies comuns, mas também às raras, exercerem influência no cálculo de similaridade (CLARKE \& WARWICK, 2001).

Com a matriz dos dados obtida, realizou-se inicialmente uma Análise de Agrupamento (Cluster) no modo $\mathrm{Q}$, com o objetivo de verificar o agrupamento das estações de cada campanha em função da distribuição das espécies de anfípodes. Para isso uma matriz de similaridade foi construída utilizando o coeficiente de similaridade de Bray-Curtis (CLARKE \& WARWICK, 2001).

Posteriormente, com a mesma matriz de similaridade de Bray-Curtis foi realizada uma análise de ordenação multidimensional não-métrica, n-MDS (Non-metric Multidimensional Scalling). Nesta análise, a partir da matriz de similaridade é construída uma matriz de postos e em base a ela as amostras são ordenadas. Semelhante a outros métodos de ordenação, no n-MDS as amostras localizadas mais próximas no diagrama de ordenação bidimensional apresentam maior semelhança entre si do que com amostras que se encontram mais afastadas (CLARKE \& WARWICK, 1994).

Com o intuito de se verificar a existência de diferenças significativas entre os grupos formados pelas análises Cluster e n-MDS foram feitas análises "a posteriori” de similaridade (ANOSIM). A análise ANOSIM é análoga à ANOVA, porém é uma análise não paramétrica, e pode ser aplicada às matrizes de dados biológicos com grande número de zeros (CLARKE \& WARWICK, 1994). Esta análise fornece um caminho para testar estatisticamente a existência de diferenças significativas entre dois ou mais grupos de amostras previamente estabelecidos e trabalha diretamente na matriz de similaridade. A estatística $R$ da ANOSIM é baseada na diferença de significância dos postos entre os grupos e dentro dos grupos e $R$ varia dentro do intervalo $-1 \ldots+1$, sendo que o valor 0 indica agrupamento completamente aleatório (CLARKE, 1993; CLARKE \& WARWICK, 1994). 
Os resultados gerados na análise ANOSIM foram complementados pela rotina estatística da Análise de Similaridade Porcentual (SIMPER). Esta análise consiste em calcular a dissimilaridade entre todos os pares de amostras dos grupos obtidos no n-MDS, e posteriormente calcular a contribuição média de cada espécie para a dissimilaridade entre os grupos de amostras, separadamente (CLARKE \& WARWICK, 1994).

Para avaliar quais as variáveis ambientais explicam melhor a distribuição espacial dos anfípodes foi aplicada a análise BIO-Env. Esta análise utiliza a matriz de similaridade de Bray-Curtis para os dados bióticos e a matriz de dissimilaridade construída a partir das variáveis ambientais padronizadas e utilizando-se o coeficiente da distância Euclidiana. Esta análise utiliza o Coeficiente de Correlação de Spearman não ponderado ( $\rho$ ) para comparar as duas matrizes, uma vez que estas não podem ser comparadas diretamente devido a diferenças em suas escalas (CLARKE \& WARWICK, 1994).

As análises estatísticas apresentadas neste trabalho foram realizadas utilizando os seguintes pacotes estatísticos: Primer versão 6.0 ${ }^{\circledR}$ e BioEstat versão 5.0. 


\section{RESULTADOS}

\subsection{Dados ambientais}

\subsubsection{Temperatura e Salinidade}

Os valores de temperatura e salinidade da água de fundo para as 21 estações de coleta das duas campanhas, inverno e verão, apresentaram as variações esperadas. No inverno, a temperatura de fundo oscilou entre 16,65 e $21,63^{\circ} \mathrm{C}$, sendo o menor registro na estação 21 e o maior na estação 1. No verão houve um maior intervalo de variação ficando a temperatura entre $15^{\circ} \mathrm{C}$ (estação 4 ) e $26,84^{\circ} \mathrm{C}$ (estação 18) (Tabela 2).

No inverno, a salinidade de fundo variou entre 33,01 e 35,86, sendo o menor valor verificado na estação 21 e o maior na estação 4. No verão a estação 18 exibiu o menor valor de salinidade, 33,07, e os maiores ocorreram nas estações 9, 19 e 17 (33,84, 33,85 e 33,86 respectivamente) (Tabela 2 ).

Quando se considera a coluna de água para a campanha de inverno, as estações amostradas na zona costeira até a isóbata de 30 m (estações 1, 5, 7, 9, 13, 16 e 18) não apresentaram uma mudança acentuada no perfil de temperatura e salinidade, conforme mostram os perfis verticais da figura 4. No verão, para as mesmas estações costeiras, foi possível verificar pequenas variações nos perfis de temperatura e salinidade e a formação de termoclinas e/ou haloclinas (Figura 5).

Uma termoclina e uma haloclina de fundo sempre presentes abaixo dos $40 \mathrm{~m}$ de profundidade (inverno) e abaixo de $20 \mathrm{~m}$ de profundidade (verão), foram observadas nas estações mais profundas nas duas campanhas (estações 4, 12, 20 e 21). As estações intermediárias, ou seja, entre a isóbata de 30 m e 50 m (estações 2, 3, 6, 8, 10, 11, 14, 15, 17 e 19), apresentaram perfis uniformes no inverno, à exceção da estação 20. No verão nestas estações foram observadas termoclina e haloclina marcantes, indicando a presença da camada de mistura (Figuras 4 e 5).

A Figura 6 apresenta o diagrama T-S que integra os pares de dados de temperatura e salinidade obtidos na coluna de água, em todas as estações. Uma análise dos gráficos mostra a presença de três massas de água na região, Água Costeira (AC), Água Tropical (AT) e Água Central do Atlântico Sul (ACAS) e a existência de variação sazonal no balanço de massa entre elas. A interação entre as três massas de água mencionadas pode ser claramente identificada pela forma triangular do diagrama T-S sazonal (Figura 6). Durante o inverno há a presença da AC e da ACAS, ambas com baixo grau de interação. No verão as três massas são marcantes, havendo mistura entre a AT e AC nas camadas superficiais da 
plataforma, e também mistura, predominantemente vertical, entre AT e ACAS e entre ACAS e AC.

No inverno a ACAS esteve recuada na parte externa da plataforma média, sendo observada apenas nas estações 4, 12 e 21, as mais profundas e sempre abaixo dos $55 \mathrm{~m}$. Contudo, na estação 20, situada mais ao sul e na isóbata de $50 \mathrm{~m}$, pode-se observar uma pequena influência da ACAS. Para o verão, como esperado, a ACAS apresentou maior intrusão na plataforma continental média (PCM) em direção a plataforma continental interna (PCI), chegando a surgir até $20 \mathrm{~m}$ de profundidade na estação 20, e $30 \mathrm{~m}$ na estação 11, ambas situadas ao redor da isóbata de $50 \mathrm{~m}$. A mesma massa (ACAS) exerce ainda influência menor entre 10 e $30 \mathrm{~m}$ de profundidade, através de sua mistura com a AC (estações 10, 15, 17 e 19). As estações mais próximas da costa apresentaram apenas a presença da $\mathrm{AC}$, ficando os valores de temperatura acima de $20^{\circ} \mathrm{C}$ e salinidade entre $33 \mathrm{e}$ 35 (Figura 6).

Tabela 2 - Valores de Profundidade (m), Temperatura $(\stackrel{o}{\mathrm{O}})$ e Salinidade da água de fundo, verificados para cada estação amostrada nas campanhas de inverno/2005 e verão/2006 na plataforma continental entre São Sebastião e Peruíbe, SP.

\begin{tabular}{ccccccc}
\hline \multirow{2}{*}{ Estações } & \multicolumn{2}{c}{ Profundidade (m) } & \multicolumn{2}{c}{ Temperatura (-C) } & \multicolumn{2}{c}{ Salinidade } \\
\cline { 2 - 6 } & Inverno/05 & Verão/06 & Inverno/05 & Verão/06 & Inverno/05 & Verão/06 \\
\hline $\mathbf{1}$ & 20,09 & 19,14 & 21,63 & 25,76 & 34,63 & 34,47 \\
$\mathbf{2}$ & 34,04 & 33,54 & 21,42 & 19,71 & 34,04 & 35,69 \\
$\mathbf{3}$ & 58,32 & 57,24 & 20,61 & 16,83 & 35,24 & 34,93 \\
$\mathbf{4}$ & 85,14 & 84,58 & 17,42 & 15,00 & 35,87 & 35,48 \\
$\mathbf{5}$ & 15,08 & 14,48 & 21,23 & 26,10 & 34,64 & 34,18 \\
$\mathbf{6}$ & 27,40 & 27,40 & 20,92 & 20,93 & 35,71 & 35,71 \\
$\mathbf{7}$ & 19,15 & 20,11 & 21,16 & 24,88 & 34,73 & 34,67 \\
$\mathbf{8}$ & 27,14 & 28,16 & 21,15 & 19,60 & 35,06 & 35,69 \\
$\mathbf{9}$ & 24,07 & 24,64 & 21,08 & 21,51 & 34,93 & 35,84 \\
$\mathbf{1 0}$ & 31,20 & 31,22 & 20,83 & 19,08 & 35,16 & 35,74 \\
$\mathbf{1 1}$ & 53,61 & 56,18 & 21,09 & 17,17 & 35,86 & 34,43 \\
$\mathbf{1 2}$ & 93,48 & 93,29 & 17,13 & 16,49 & 35,83 & 35,71 \\
$\mathbf{1 3}$ & 16,23 & 15,39 & 21,10 & 25,96 & 34,95 & 34,07 \\
$\mathbf{1 4}$ & 26,26 & 24,64 & 21,00 & 22,21 & 35,12 & 35,80 \\
$\mathbf{1 5}$ & 31,60 & 31,15 & 20,72 & 18,61 & 35,18 & 35,70 \\
$\mathbf{1 6}$ & 13,47 & 14,14 & 21,02 & 26,33 & 34,87 & 33,82 \\
$\mathbf{1 7}$ & 30,68 & 30,09 & 20,51 & 20,07 & 35,05 & 35,86 \\
$\mathbf{1 8}$ & 15,29 & 14,51 & 20,97 & 26,84 & 34,64 & 33,07 \\
$\mathbf{1 9}$ & 27,38 & 28,56 & 20,92 & 20,65 & 34,63 & 35,85 \\
$\mathbf{2 0}$ & 49,68 & 49,54 & 21,02 & 17,22 & 35,81 & 35,71 \\
$\mathbf{2 1}$ & 97,07 & 96,24 & 16,65 & 17,00 & 35,76 & 35,48 \\
\hline \hline
\end{tabular}



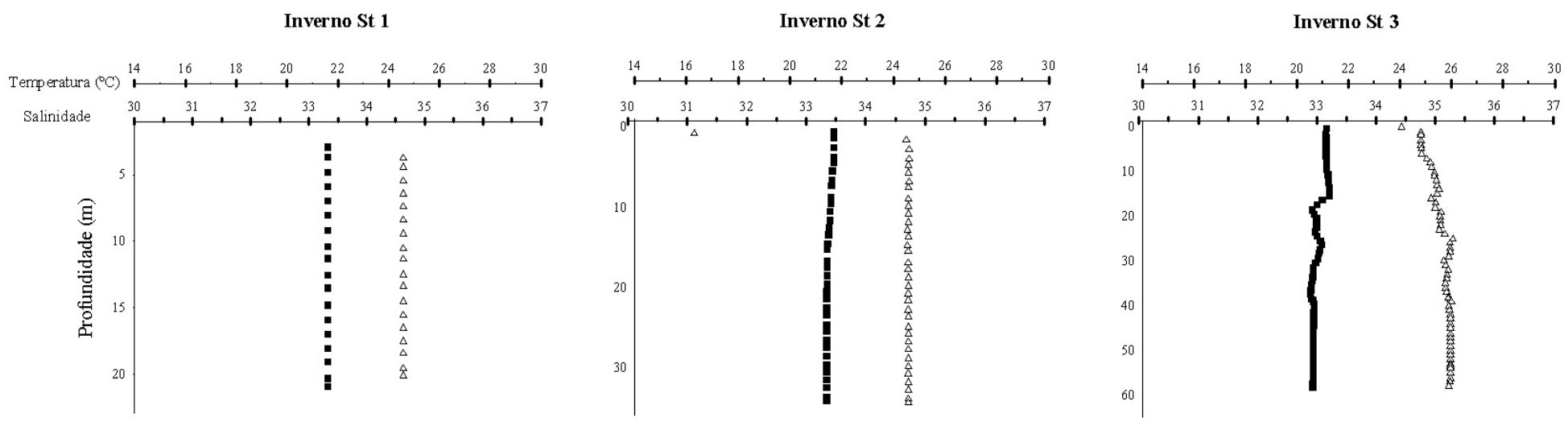

Inverno $\mathrm{St} 4$

Inverno St 5

Inverno $\mathrm{St} 6$
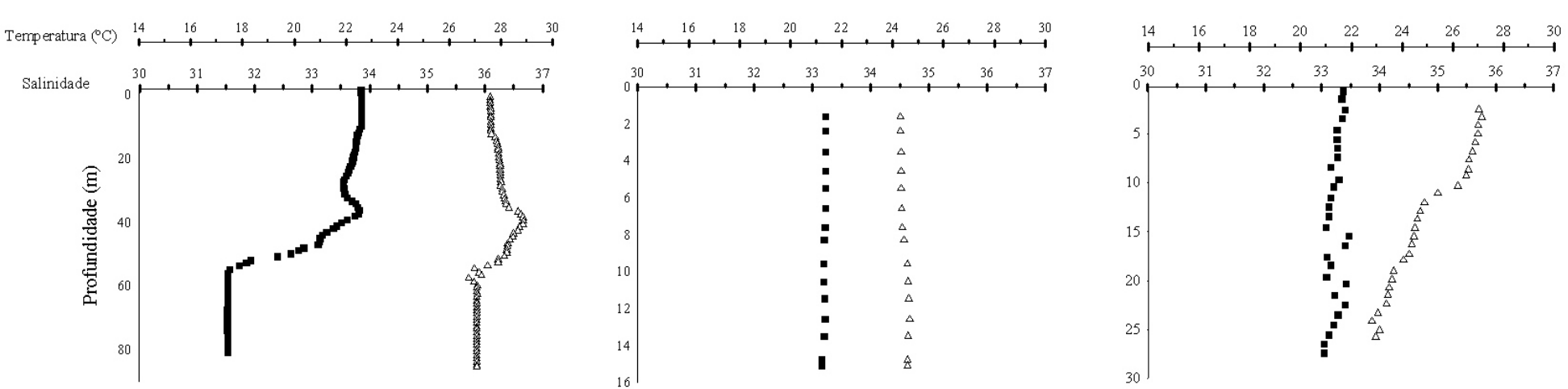

$\triangle \quad$ Salinidade

- Temperatura

Figura 4 - Perfis de temperatura e salinidade para as estações coletadas na campanha de inverno (agosto e setembro de 2005) na plataforma continental entre São Sebastião e Peruíbe, SP. 

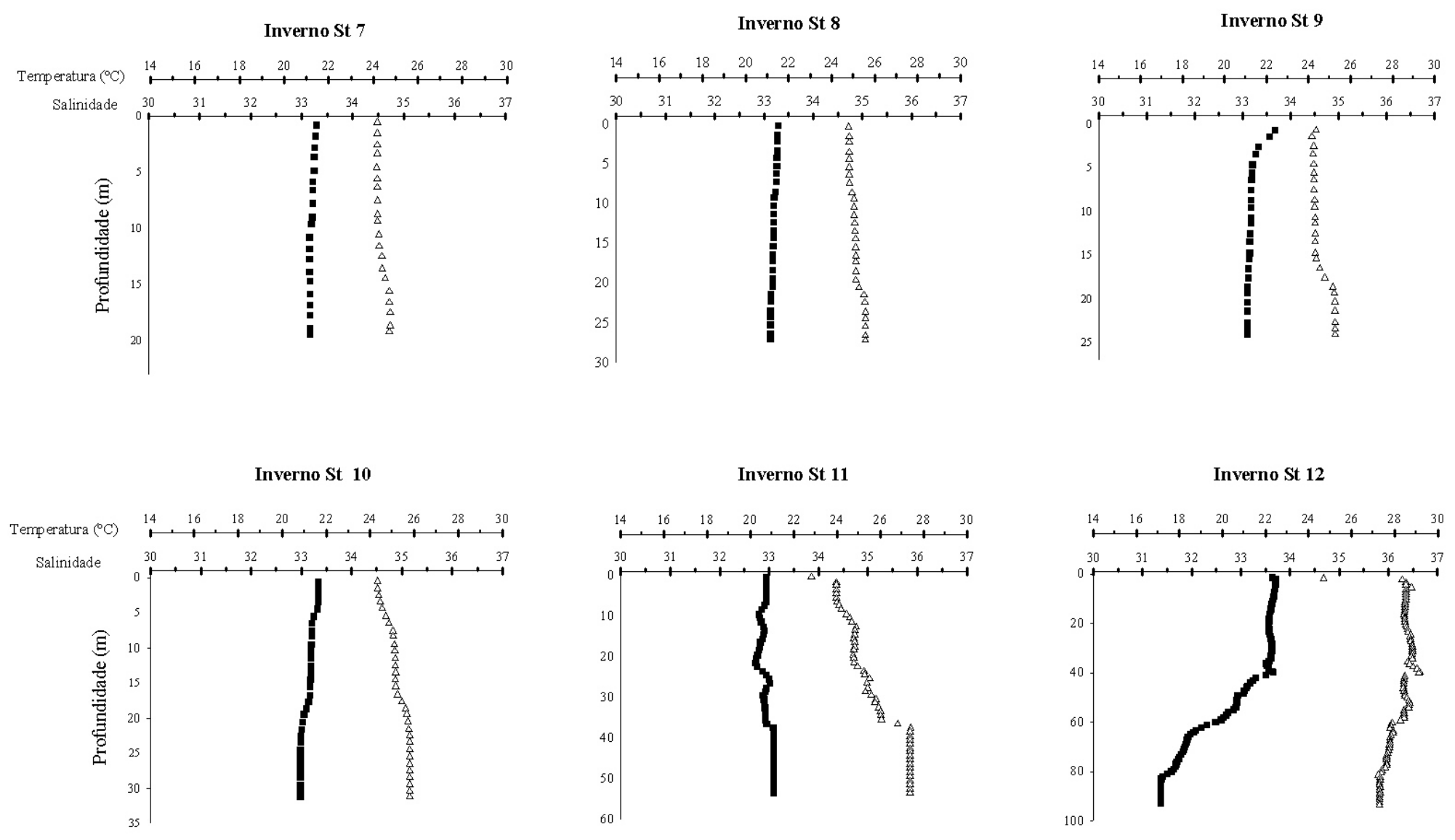
Inverno St 13

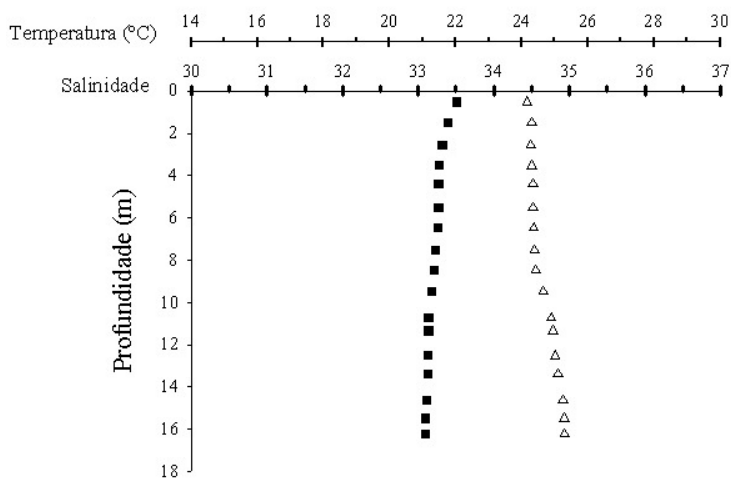

Inverno St 16

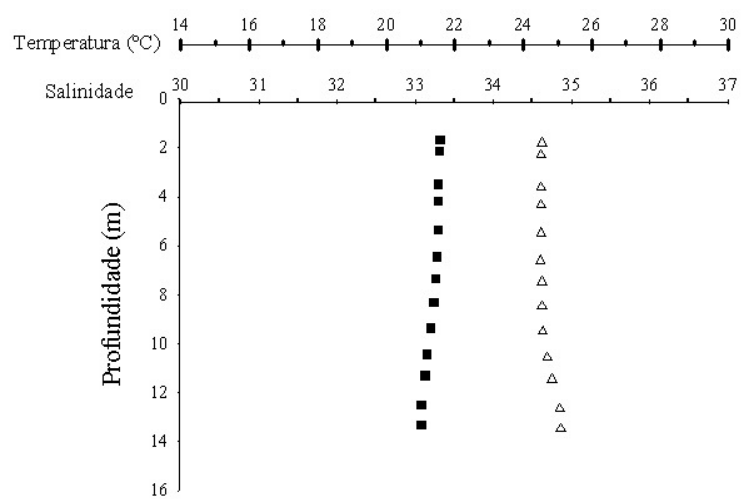

Inverno St 14

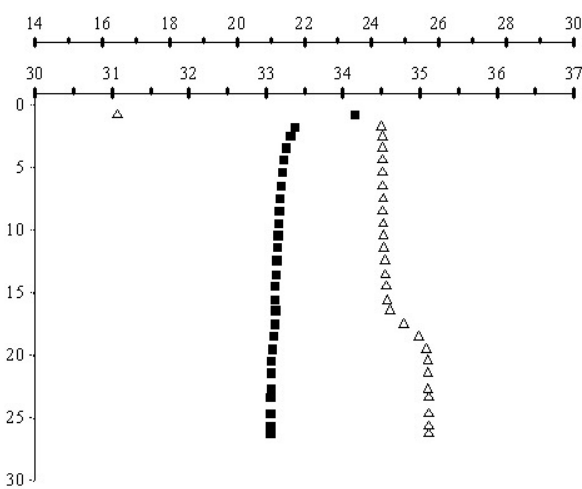

Inverno St 17

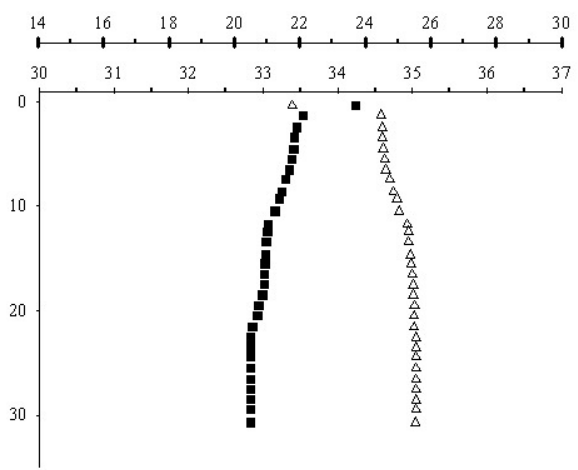

Inverno St 15

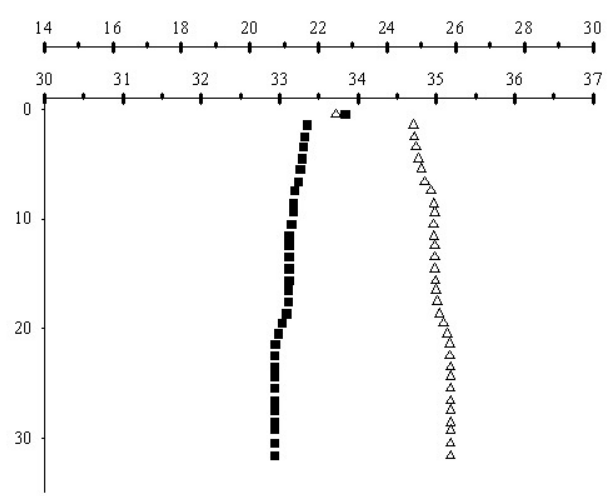

Inverno St 18

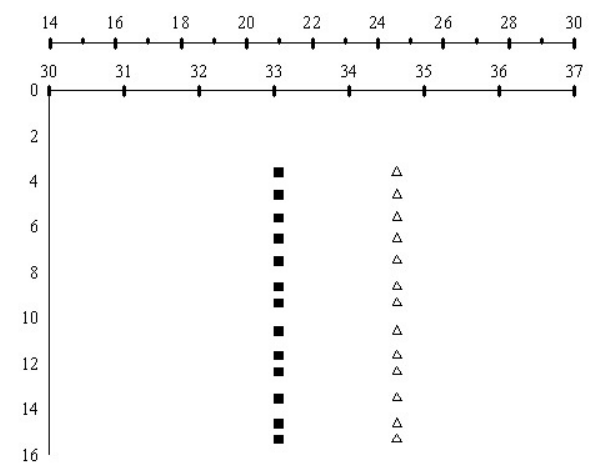


Inverno St 19

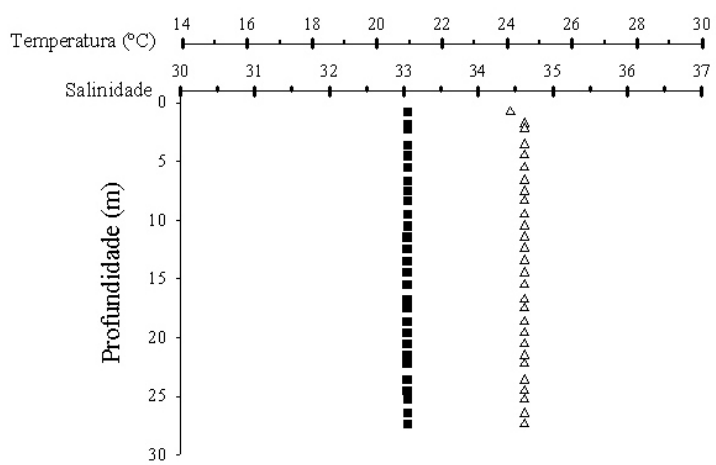

Inverno St 20

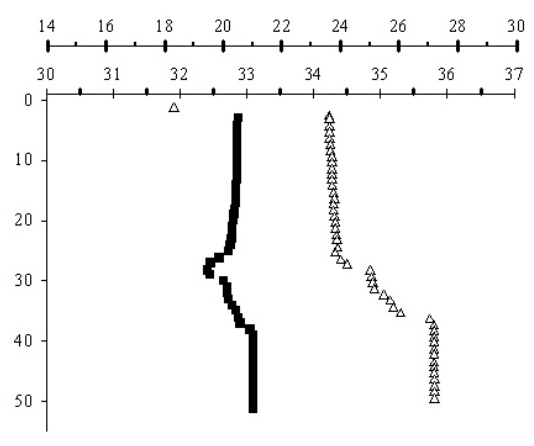

Inverno St 21

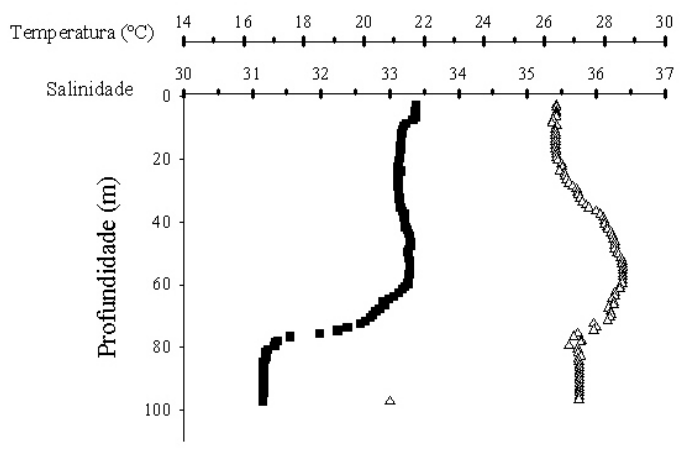

$\triangle \quad$ Salinidade

- Temperatura

Figura 4 - Continuação. 

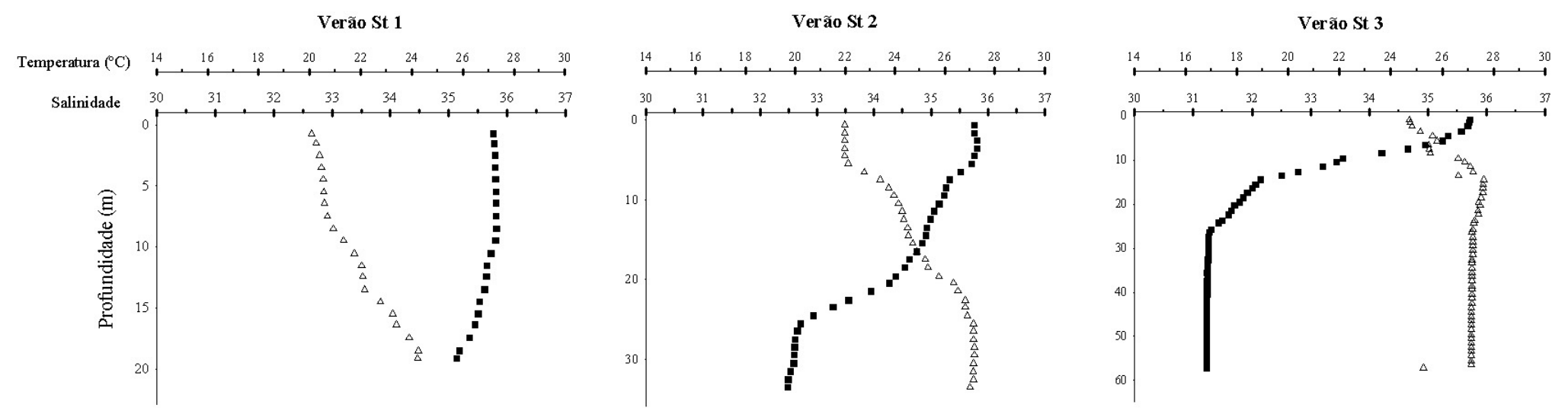

Verão St 4

Verão St 5

Verão St 6
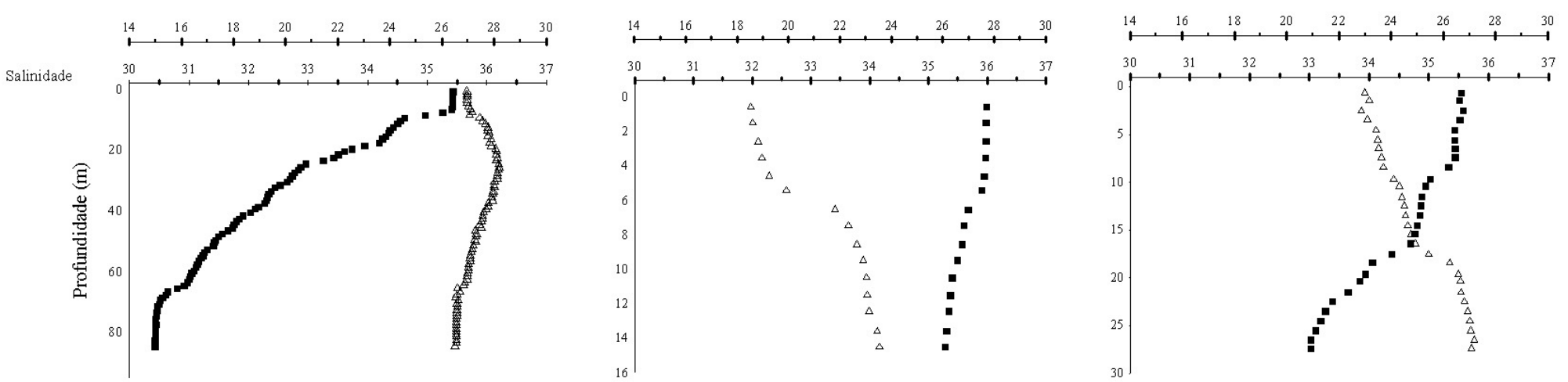

$\triangle \quad$ Salinidade

- Temperatura

Figura 5 - Perfis de temperatura e salinidade para as estações coletadas na campanha de verão (fevereiro de 2006) na plataforma continental entre São Sebastião e Peruíbe, SP. 
Verão St 7
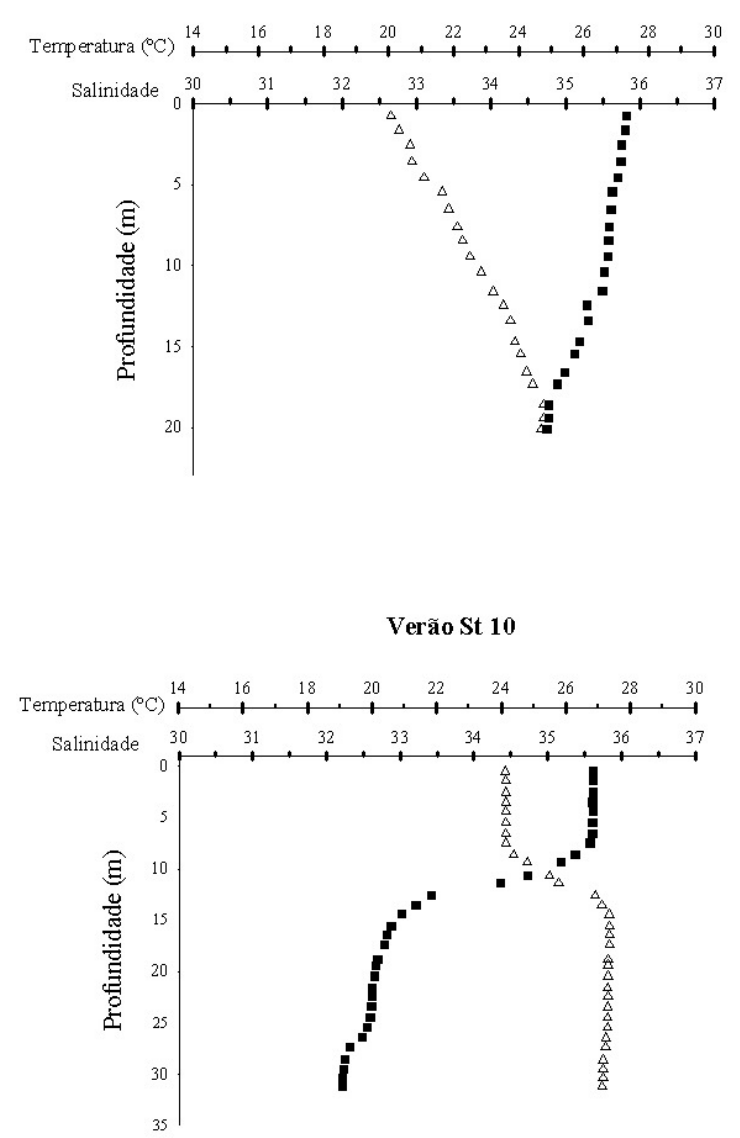

Verão St 8
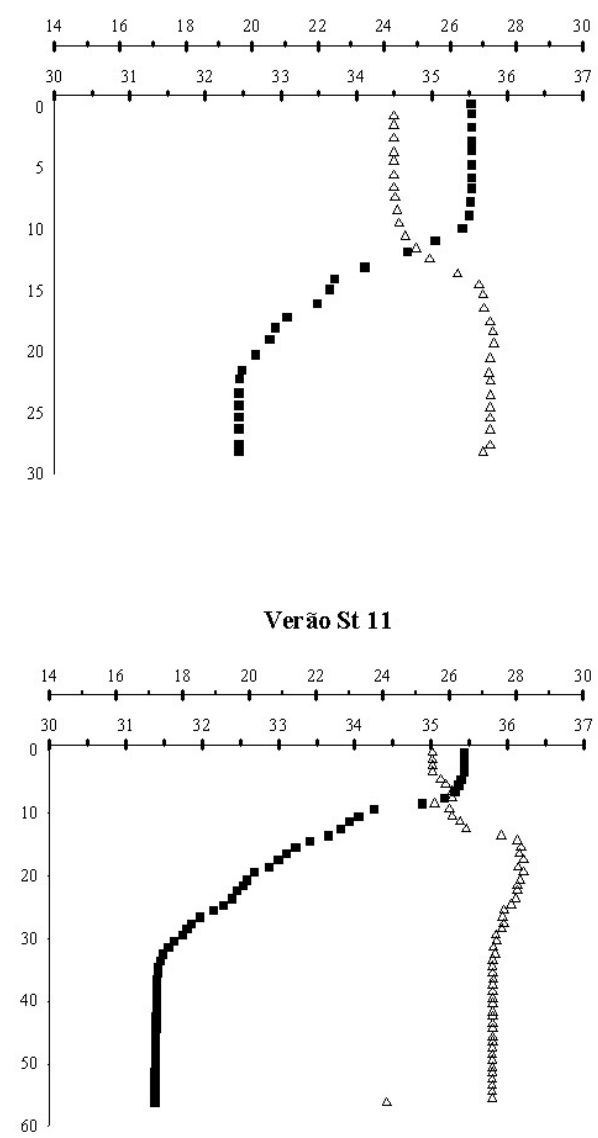

Verão St 9
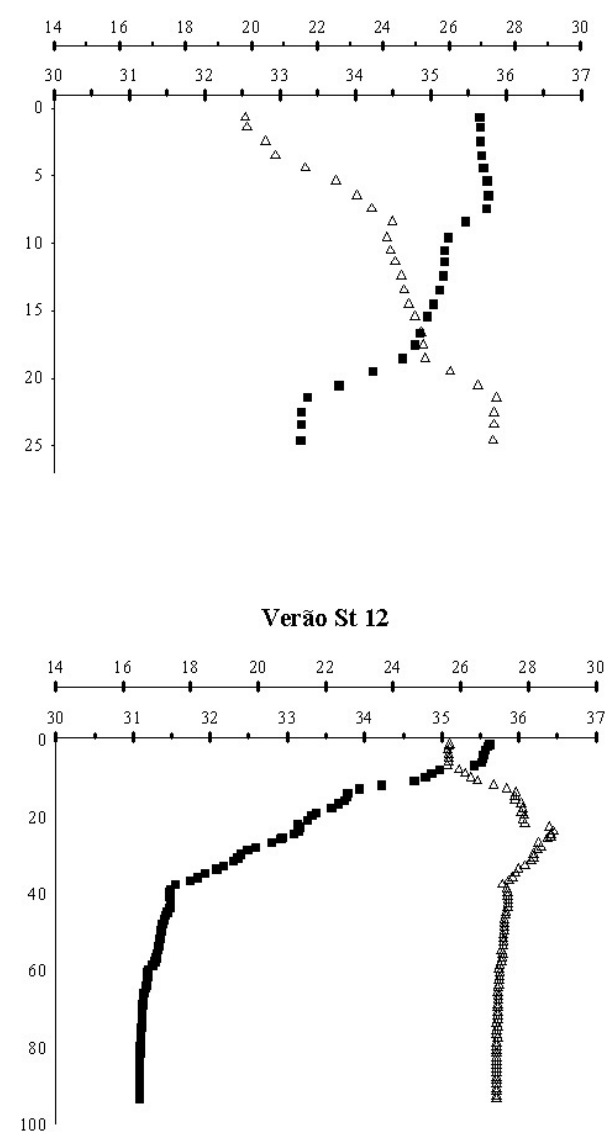

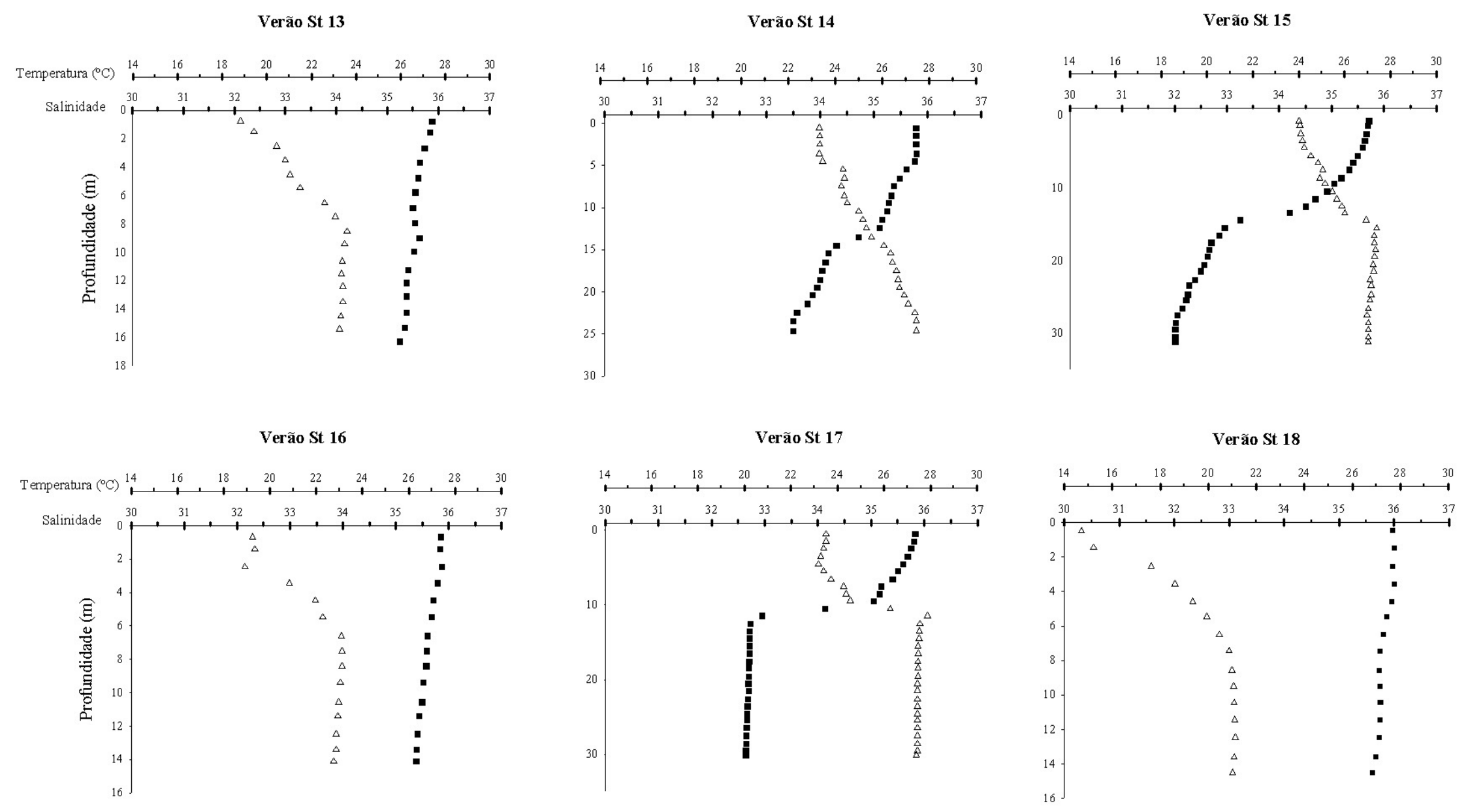

$\triangle \quad$ Salinidade

Temperatura

Figura 5 - Continuação. 
Figura 5 - Continuação.

Verão St 19

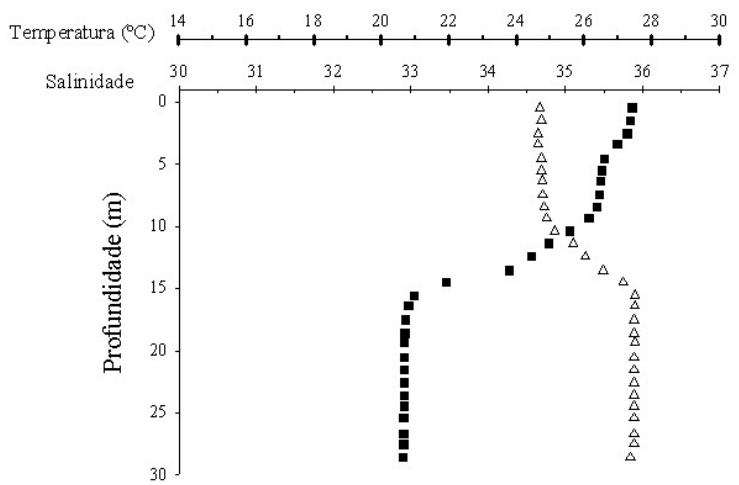

Verão St 20

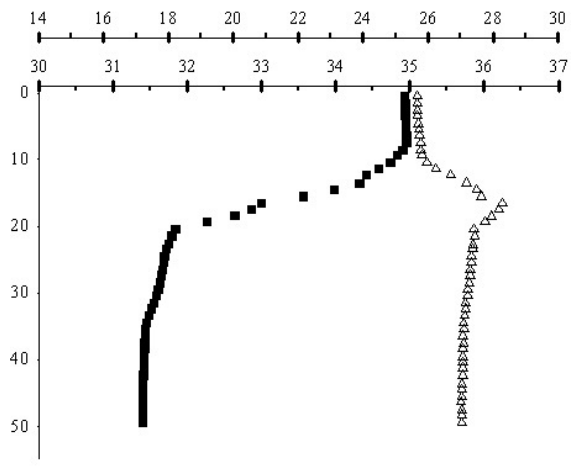

Verão St 21

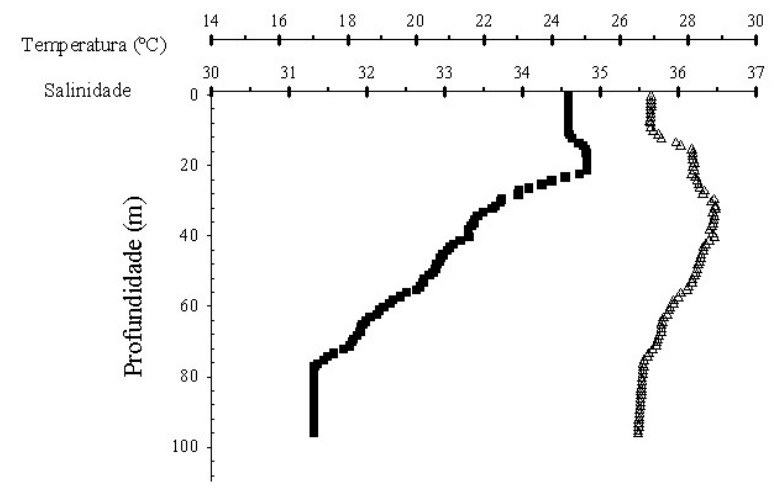

Inverno / 2005

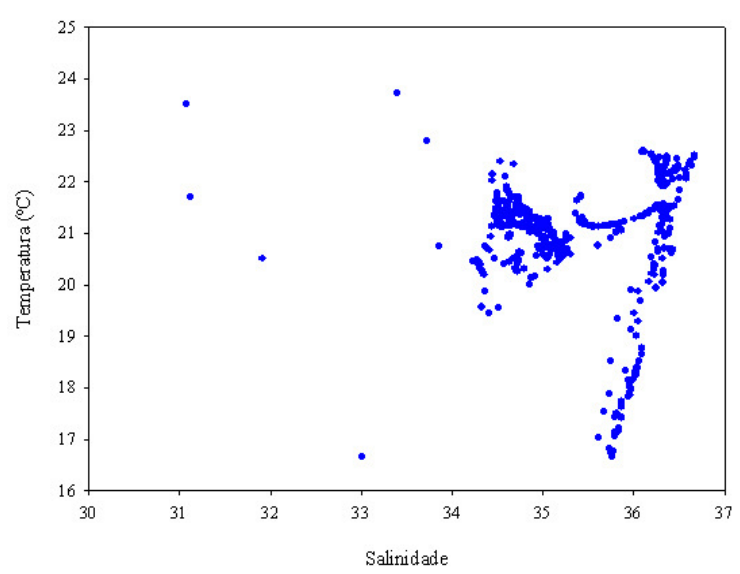

Verão / 2006

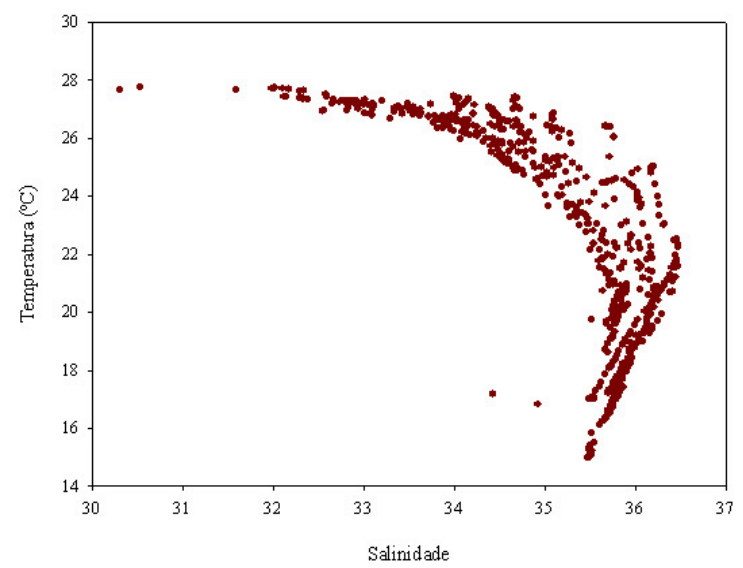

Figura 6 - Diagramas T-S para os pares de dados obtidos nas estações das campanhas de inverno e verão na plataforma continental entre São Sebastião e Peruíbe, SP. 


\subsubsection{Sedimento}

Os resultados das análises granulométricas mostraram que as frações sedimentológicas areia fina e muito fina foram as predominantes nas estações amostradas nas duas campanhas.

No inverno, os grânulos representaram entre 0 e 10\% (valores médios) do total das frações granulométricas. Os valores médios de areia muito fina variaram entre 1,35 e $90 \%$, enquanto que os valores médios de argila variaram entre 0 e $61,4 \%$, sendo que os maiores valores foram encontrados nas estações mais profundas 12 e 21 (Tabela 3 e Figura 7). No verão a fração correspondente aos grânulos variaram entre 0 e 4,1\%. Os valores médios de areia muito fina variaram entre 1,37 e $91 \%$. Os valores médios de silte variaram entre 0 e $68 \%$, novamente os maiores valores de silte foram encontrados nas estações 12 e 21 (Tabela 4 e Figura 8). As estações 2, 4, 11 e 21 (esta última no inverno somente), apresentaram uma maior heterogeneidade sedimentar com a ocorrência de várias frações granulométricas com porcentagens relativamente altas (Tabelas 3 e 4; Figuras 7 e 8).

Quando comparamos a composição sedimentar das estações nas duas campanhas, observamos que para a maioria delas não há variação. As exceções a esta observação podem ser verificadas nas estações 6, 9, 18, 12 e 21. No verão, nas estações costeiras 6, 9 e 18 houve um aumento na porcentagem de sedimentos mais finos (silte e argila) nos três estratos amostrados; na estação externa 12 ocorreu uma diminuição significativa de argila em relação ao silte, e na estação 21 houve um aumento da porcentagem de argila em relação à de silte (Tabelas 3 e 4; Figuras 7 e 8).

Quanto à distribuição vertical do sedimento, a composição granulométrica não exibiu grandes variações entre os estratos (Tabelas 3 e 4; Figuras 7 e 8). Quanto ao grau de seleção, o sedimento de todos os estratos coletados nas duas campanhas evidenciou grande variabilidade, sendo classificados de pobremente selecionados a muito bem selecionados. Houve um predomínio dos sedimentos bem selecionados e constatou-se que apenas nas estações 2 e 21, no inverno, e nas estações 2, 6, 9 e 18 no verão, ocorreram sedimentos classificados como muito pobremente selecionados em algum dos estratos (Tabelas 3 e 4).

Os valores médios de matéria orgânica total no inverno variaram entre 0,91 e 8,73 e os valores mais elevados foram encontrados principalmente no estrato de meio para a maioria das estações (no total 10). Os maiores valores no estrato de superfície foram obtidos nas estações 12 e 21 (8,96 e 6,78\%, respectivamente); no estrato de meio na 
estação $1(12,94 \%)$ e no estrato inferior na estação 12 (9,19\%). Os valores médios de matéria orgânica total no verão variaram entre 0,88 e 12,54, sendo que os maiores valores foram obtidos principalmente no estrato inferior (no total 9). Os maiores valores no estrato de superfície foram observados nas estações 12 e 21 (12,28 e 17,57\%, respectivamente); no estrato de meio nas estações 12 e 18 (13,04 e 14,48\%, respectivamente) e no estrato inferior nas estações 2 e 13 (15,95 e 21,64\%, respectivamente) (Tabela 5 e Figura 9).

A porcentagem de carbonato das amostras de sedimento apresentou uma alta variabilidade (estação 18: 2,1\% e estação 12: 33,17\%, inverno; estação 7: 2,1\% e estação 11: 30,8\%, verão). Os maiores valores, considerando-se a somatória de todos os estratos, foram similares para as duas campanhas, e encontrados na estação 11, localizada próximo da isóbata de 50 m e nas estações 4, 12 e 21, localizadas próximas à isóbata de $100 \mathrm{~m}$. Este fato mostrou uma tendência para os valores mais elevados estarem situados em locais mais profundos (Tabela 5 e Figura 9). 
Tabela 3 - Granulometria e classificação dos sedimentos das amostras coletadas no inverno de 2005 na plataforma continental entre São Sebastião e Peruíbe, SP. GRN - grânulos; AMG - areia muito grossa; AG - areia grossa; AM - areia média; AF - areia fina; AMF - areia muito fina; SIL - silte; ARG - argila; MBS - muito bem selecionado; BMS - bem selecionado; POS - pobremente selecionado; MPS - muito pobremente selecionado; MOS - moderadamente selecionado. Classificação segundo Folk \& Ward, 1957.

\begin{tabular}{|c|c|c|c|c|c|c|c|c|c|c|c|c|}
\hline Estações & Estrato & $\begin{array}{c}\text { GRN } \\
(\%)\end{array}$ & $\begin{array}{c}\text { AMG } \\
(\%)\end{array}$ & $\begin{array}{l}\text { AG } \\
(\%)\end{array}$ & $\begin{array}{l}\text { AM } \\
(\%)\end{array}$ & $\begin{array}{l}\text { AF } \\
(\%)\end{array}$ & $\begin{array}{r}\text { AMF } \\
(\%)\end{array}$ & $\begin{array}{l}\text { SIL } \\
(\%)\end{array}$ & $\begin{array}{c}\text { ARG } \\
(\%)\end{array}$ & $\begin{array}{l}\text { Diâmetro } \\
\text { Médio }(\phi)\end{array}$ & $\begin{array}{l}\text { Grau de } \\
\text { Seleção }\end{array}$ & Classe \\
\hline \multirow{3}{*}{1} & Superfície & 0,00 & 0,00 & 0,06 & 0,14 & 3,44 & 89,61 & 1,69 & 5,06 & 3,44 & MOS & \multirow{3}{*}{$\begin{array}{l}\text { areia muito fina } \\
\text { silte grosso } \\
\text { areia muito fina }\end{array}$} \\
\hline & Meio & 0,00 & 0,00 & 0,03 & 0,06 & 1,94 & 72,88 & 10,03 & 15,05 & 4,46 & POS & \\
\hline & Fundo & 0,00 & 0,00 & 0,06 & 0,17 & 3,79 & 90,89 & 1,69 & 3,39 & 3,43 & MOS & \\
\hline \multirow{3}{*}{2} & Superfície & 9,39 & 3,21 & 1,71 & 1,78 & 16,53 & 58,85 & 3,42 & 5,12 & 2,94 & POS & \multirow{3}{*}{$\begin{array}{c}\text { areia fina } \\
\text { silte grosso } \\
\text { silte grosso }\end{array}$} \\
\hline & Meio & 5,86 & 2,24 & 1,22 & 1,56 & 16,37 & 54,10 & 5,08 & 13,56 & 4,39 & MPS & \\
\hline & Fundo & 3,90 & 2,17 & 1,22 & 1,63 & 16,37 & 54,39 & 6,78 & 13,55 & 4,42 & MPS & \\
\hline \multirow{3}{*}{3} & Superfície & 0,20 & 0,30 & 0,37 & 0,64 & 10,01 & 75,00 & 1,68 & 11,79 & 3,45 & POS & \multirow{3}{*}{$\begin{array}{l}\text { areia muito fina } \\
\text { areia muito fina } \\
\text { areia muito fina }\end{array}$} \\
\hline & Meio & 0,20 & 0,24 & 0,34 & 0,48 & 9,46 & 73,92 & 3,41 & 11,95 & 3,47 & POS & \\
\hline & Fundo & 0,30 & 0,40 & 0,47 & 0,64 & 9,26 & 72,07 & 5,05 & 11,79 & 3,98 & POS & \\
\hline \multirow{3}{*}{4} & Superfície & 3,62 & 3,06 & 1,69 & 2,60 & 44,09 & 31,65 & 4,99 & 8,31 & 3,01 & POS & \multirow{3}{*}{$\begin{array}{l}\text { areia muito fina } \\
\text { areia muito fina } \\
\text { areia muito fina }\end{array}$} \\
\hline & Meio & 3,96 & 3,17 & 1,66 & 2,48 & 43,28 & 28,95 & 4,95 & 11,55 & 3,26 & POS & \\
\hline & Fundo & 3,76 & 3,02 & 1,58 & 2,65 & 44,12 & 29,79 & 3,35 & 11,74 & 3,08 & POS & \\
\hline \multirow{3}{*}{5} & Superfície & 0,00 & 0,00 & 0,03 & 0,07 & 4,73 & 90,01 & 1,69 & 3,38 & 3,56 & BMS & \multirow{3}{*}{$\begin{array}{l}\text { areia muito fina } \\
\text { areia muito fina } \\
\text { areia muito fina }\end{array}$} \\
\hline & Meio & 0,00 & 0,00 & 0,03 & 0,13 & 4,61 & 90,15 & 3,38 & 1,69 & 3,56 & MBS & \\
\hline & Fundo & 0,00 & 0,00 & 0,00 & 0,10 & 4,79 & 90,01 & 1,70 & 3,40 & 3,56 & BMS & \\
\hline \multirow{3}{*}{6} & Superfície & 1,79 & 0,14 & 0,17 & 0,13 & 10,28 & 77,55 & 3,32 & 6,63 & 3,39 & POS & areia muito fina \\
\hline & Meio & 0,27 & 0,14 & 0,20 & 0,17 & 11,18 & 79,73 & 1,66 & 6,66 & 3,37 & MOS & areia muito fina \\
\hline & Fundo & 0,27 & 0,14 & 0,20 & 0,17 & 11,02 & 78,22 & 3,33 & 6,66 & 3,38 & POS & areia muito fina \\
\hline & Superfície & 0,00 & 0,00 & 0,10 & 0,10 & 7,53 & 76,89 & 6,84 & 8,55 & 3,60 & POS & areia muito fina \\
\hline 7 & Meio & 0,00 & 0,06 & 0,06 & 0,20 & 8,58 & 81,03 & 6,70 & 3,35 & 3,56 & MOS & areia muito fina \\
\hline & Fundo & 0,03 & 0,03 & 0,10 & 0,17 & 8,94 & 82,26 & 6,77 & 1,69 & 3,56 & BMS & areia muito fina \\
\hline & Superfície & 0,13 & 0,59 & 0,88 & 0,95 & 27,44 & 63,49 & 1,63 & 4,90 & 3,19 & MOS & areia muito fina \\
\hline 8 & Meio & 0,53 & 1,80 & 1,48 & 1,25 & 27,46 & 60,90 & 1,64 & 4,93 & 3,11 & MOS & areia muito fina \\
\hline & Fundo & 0,50 & 1,66 & 1,32 & 1,09 & 27,91 & 62,51 & 3,32 & 1,66 & 3,13 & BMS & areia muito fina \\
\hline & Superfície & 0,00 & 0,07 & 0,10 & 0,13 & 7,86 & 85,03 & 3,40 & 3,40 & 3,54 & BMS & areia muito fina \\
\hline 9 & Meio & 0,03 & 0,03 & 0,13 & 0,38 & 5,62 & 69,97 & 12,07 & 12,06 & 4,59 & POS & silte grosso \\
\hline & Fundo & 0,07 & 0,00 & 0,06 & 0,24 & 4,54 & 61,95 & 20,94 & 12,21 & 4,75 & POS & silte grosso \\
\hline & Superfície & 0,00 & 0,55 & 0,75 & 0,99 & 41,81 & 54,98 & 0,00 & 0,00 & 3,04 & MBS & areia muito fina \\
\hline 10 & Meio & 0,96 & 1,62 & 1,52 & 1,37 & 42,66 & 51,85 & 0,00 & 0,00 & 2,99 & BMS & areia fina \\
\hline & Fundo & 2,75 & 1,96 & 1,89 & 1,32 & 39,46 & 47,67 & 1,65 & 3,31 & 3,01 & MOS & areia muito fina \\
\hline & Superfície & 4,43 & 2,14 & 1,40 & 1,43 & 14,19 & 61,05 & 5,12 & 10,23 & 3,42 & POS & areia muito fina \\
\hline 11 & Meio & 7,59 & 2,90 & 1,69 & 1,59 & 14,67 & 56,39 & 3,37 & 11,80 & 3,34 & POS & areia muito fina \\
\hline & Fundo & 3,33 & 2,52 & 1,90 & 1,77 & 15,21 & 59,95 & 3,40 & 11,91 & 3,41 & POS & areia muito fina \\
\hline & Superfície & 0,00 & 0,00 & 0,00 & 0,00 & 0,00 & 1,51 & 37,75 & 60,74 & 7,71 & POS & silte muito fino \\
\hline 12 & Meio & 0,26 & 0,27 & 0,27 & 0,53 & 1,92 & 2,52 & 33,07 & 61,18 & 7,68 & POS & silte muito fino \\
\hline & Fundo & 0,00 & 0,00 & 0,00 & 0,00 & 0,00 & 3,09 & 34,49 & 62,42 & 7,73 & POS & silte muito fino \\
\hline & Superfície & 0,00 & 0,00 & 0,06 & 0,06 & 0,33 & 91,18 & 5,01 & 3,34 & 3,68 & MOS & areia muito fina \\
\hline 13 & Meio & 0,00 & 0,00 & 0,03 & 0,10 & 0,52 & 85,46 & 8,67 & 5,20 & 3,72 & MOS & areia muito fina \\
\hline & Fundo & 0,00 & 0,00 & 0,04 & 0,11 & 0,50 & 85,36 & 8,76 & 5,25 & 3,72 & MOS & areia muito fina \\
\hline & Superfície & 0,03 & 0,13 & 0,13 & 0,56 & 44,54 & 48,09 & 3,26 & 3,26 & 3,11 & MOS & areia muito fina \\
\hline 14 & Meio & 0,03 & 0,16 & 0,22 & 0,75 & 44,96 & 47,37 & 3,25 & 3,25 & 3,10 & MOS & areia muito fina \\
\hline & Fundo & 0,00 & 0,13 & 0,19 & 0,84 & 45,09 & 44,02 & 3,24 & 6,48 & 3,14 & POS & areia muito fina \\
\hline & Superfície & 0,03 & 0,21 & 0,31 & 0,69 & 50,19 & 48,57 & 0,00 & 0,00 & 3,00 & MBS & areia fina \\
\hline 15 & Meio & 0,03 & 0,13 & 0,28 & 0,79 & 50,29 & 48,48 & 0,00 & 0,00 & 3,00 & MBS & areia fina \\
\hline & Fundo & 0,62 & 1,44 & 1,41 & 1,51 & 50,16 & 44,85 & 0,00 & 0,00 & 2,95 & BMS & areia fina \\
\hline & Superfície & 0,07 & 0,06 & 0,06 & 0,60 & 4,55 & 88,01 & 1,66 & 4,98 & 3,55 & BMS & areia muito fina \\
\hline 16 & Meio & 0,13 & 0,06 & 0,13 & 0,59 & 4,10 & 88,39 & 1,65 & 4,95 & 3,54 & BMS & areia muito fina \\
\hline & Fundo & 0,00 & 0,00 & 0,06 & 0,10 & 1,71 & 91,43 & 1,67 & 5,02 & 3,56 & MOS & areia muito fina \\
\hline & Superfície & 0,00 & 0,10 & 0,31 & 1,04 & 22,19 & 76,36 & 0,00 & 0,00 & 3,18 & MBS & areia muito fina \\
\hline 17 & Meio & 0,17 & 0,14 & 0,38 & 0,97 & 21,90 & 76,45 & 0,00 & 0,00 & 3,18 & MBS & areia muito fina \\
\hline & Fundo & 0,30 & 0,46 & 0,63 & 1,59 & 23,46 & 68,60 & 0,00 & 4,97 & 3,18 & BMS & areia muito fina \\
\hline & Superfície & 0,03 & 0,06 & 0,10 & 0,30 & 4,80 & 87,95 & 3,37 & 3,37 & 3,62 & BMS & areia muito fina \\
\hline 18 & Meio & 0,00 & 0,03 & 0,06 & 0,13 & 2,39 & 90,54 & 5,12 & 1,71 & 3,65 & BMS & areia muito fina \\
\hline & Fundo & 0,00 & 0,00 & 0,03 & 0,10 & 1,80 & 91,37 & 3,34 & 3,34 & 3,61 & BMS & areia muito fina \\
\hline & Superfície & 0,07 & 0,20 & 0,28 & 1,38 & 28,17 & 69,90 & 0,00 & 0,00 & 3,13 & BMS & areia muito fina \\
\hline 19 & Meio & 0,14 & 0,31 & 0,31 & 1,68 & 28,66 & 68,91 & 0,00 & 0,00 & 3,11 & BMS & areia muito fina \\
\hline & Fundo & 0,17 & 0,24 & 0,31 & 1,59 & 28,18 & 69,52 & 0,00 & 0,00 & 3,12 & BMS & areia muito fina \\
\hline & Superfície & 0,27 & 0,40 & 0,64 & 0,74 & 5,97 & 80,24 & 3,36 & 8,39 & 3,61 & POS & areia muito fina \\
\hline 20 & Meio & 1,79 & 1,05 & 0,88 & 0,98 & 6,77 & 76,68 & 3,39 & 8,46 & 3,57 & POS & areia muito fina \\
\hline & Fundo & 2,23 & 0,95 & 0,98 & 1,05 & 6,86 & 76,09 & 5,07 & 6,76 & 3,56 & POS & areia muito fina \\
\hline & Superfície & 10,15 & 5,29 & 5,36 & 4,40 & 2,92 & 1,28 & 22,99 & 47,62 & 5,56 & MPS & silte médio \\
\hline 21 & Meio & 12,22 & 5,30 & 7,12 & 6,21 & 4,00 & 1,81 & 17,87 & 45,48 & 5,25 & MPS & silte médio \\
\hline & Fundo & 9,33 & 4,96 & 5,28 & 4,31 & 2,24 & 0,97 & 19,44 & 53,47 & 5,77 & MPS & silte médio \\
\hline
\end{tabular}



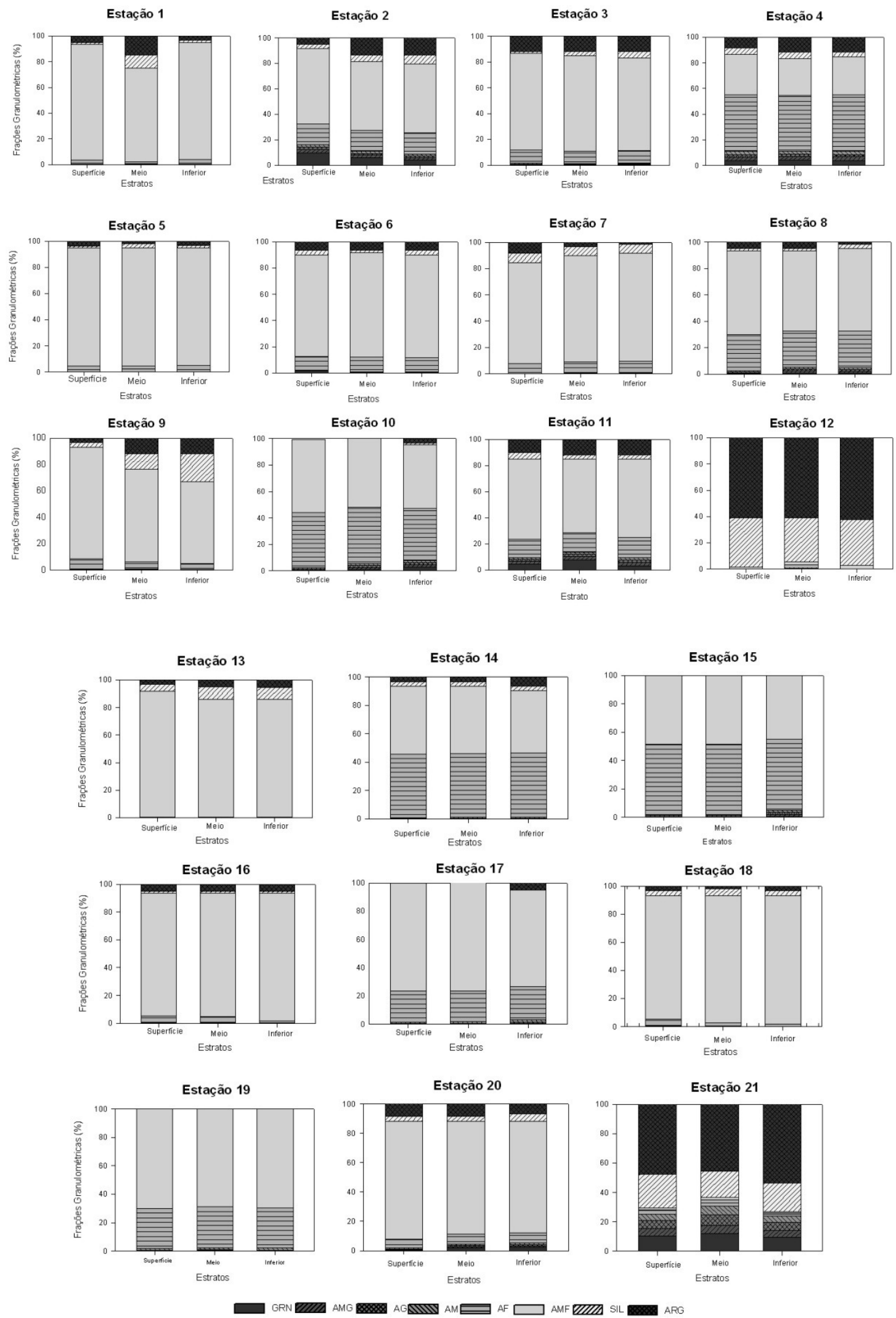

Figura 7 - Distribuição das frações granulométricas nos diferentes estratos (superfície, meio e inferior) das amostras de sedimento coletadas na campanha de inverno nas estações da plataforma continental entre São Sebastião e Peruíbe, SP. GRN: grânulo, AMG: areia muito grossa, AG: areia grossa, AM: areia média; AF: areia fina, AMF: areia muito fina, SIL: silte e ARG: argila. 
Tabela 4 - Granulometria e classificação dos sedimentos das amostras coletadas no verão de 2006 na plataforma continental entre São Sebastião e Peruíbe, SP. GRN - grânulos; AMG - areia muito grossa; AG - areia grossa; AM - areia média; AF - areia fina; AMF - areia muito fina; SIL - silte; ARG argila; MBS - muito bem selecionado; BMS - bem selecionado; POS - pobremente selecionado; MPS - muito pobremente selecionado; MOS - moderadamente selecionado. Classificação segundo Folk \& Ward, 1957.

\begin{tabular}{|c|c|c|c|c|c|c|c|c|c|c|c|c|}
\hline Estações & Estrato & $\begin{array}{l}\text { GRN } \\
(\%)\end{array}$ & $\begin{array}{l}\text { AMG } \\
(\%)\end{array}$ & $\begin{array}{l}\text { AG } \\
(\%)\end{array}$ & $\begin{array}{l}\text { AM } \\
(\%)\end{array}$ & $\begin{array}{l}\mathrm{AF} \\
(\%)\end{array}$ & $\begin{array}{l}\text { AMF } \\
(\%)\end{array}$ & $\begin{array}{l}\text { SIL } \\
(\%)\end{array}$ & $\begin{array}{c}\text { ARG } \\
(\%)\end{array}$ & $\begin{array}{l}\text { Diâmetro } \\
\text { Médio }(\phi)\end{array}$ & $\begin{array}{l}\text { Grau de } \\
\text { Seleção }\end{array}$ & Classe \\
\hline \multirow{3}{*}{1} & \begin{tabular}{|l|} 
Superfície \\
\end{tabular} & 0,00 & 0,03 & 0,07 & 0,17 & 4,27 & 90,37 & 1,70 & 3,39 & 3,42 & MBS & areia muito fina \\
\hline & Meio & 0,00 & 0,00 & 0,10 & 0,17 & 4,47 & 91,84 & 1,71 & 1,71 & 3,40 & MBS & areia muito fina \\
\hline & Fundo & 0,00 & 0,00 & 0,10 & 0,17 & 4,31 & 90,33 & 1,70 & 3,39 & 3,42 & MBS & areia muito fina \\
\hline \multirow{3}{*}{2} & Superfície & 1,74 & 2,17 & 1,20 & 1,07 & 12,94 & 69,16 & 1,67 & 10,03 & 3,35 & POS & areia muito fina \\
\hline & Meio & 3,09 & 1,63 & 1,37 & 1,37 & 13,25 & 61,40 & 4,88 & 13,02 & 4,41 & MPS & silte grosso \\
\hline & Fundo & 1,16 & 1,10 & 0,96 & 1,32 & 12,86 & 62,71 & 6,63 & 13,26 & 4,58 & MPS & silte grosso \\
\hline \multirow{3}{*}{3} & Superfície & 0,10 & 0,30 & 0,30 & 0,44 & 9,18 & 74,49 & 5,06 & 10,12 & 3,48 & POS & areia muito fina \\
\hline & Meio & 0,20 & 0,20 & 0,40 & 0,50 & 9,43 & 72,62 & 5,00 & 11,66 & 3,61 & POS & areia muito fina \\
\hline & Fundo & 0,13 & 0,30 & 0,37 & 0,54 & 9,35 & 74,22 & 6,70 & 8,38 & 3,47 & POS & areia muito fina \\
\hline \multirow{3}{*}{4} & Superfície & 4,11 & 3,50 & 1,95 & 2,69 & 43,82 & 32,13 & 5,05 & 6,74 & 3,02 & POS & areia muito fina \\
\hline & Meio & 3,99 & 3,15 & 2,02 & 2,97 & 43,06 & 31,26 & 5,07 & 8,46 & 2,98 & POS & areia fina \\
\hline & Fundo & 4,05 & 3,38 & 1,91 & 2,74 & 43,29 & 31,24 & 5,02 & 8,37 & 3,06 & POS & areia muito fina \\
\hline \multirow{3}{*}{5} & Superfície & 0,00 & 0,00 & 0,03 & 0,03 & 3,74 & 92,75 & 1,72 & 1,72 & 3,55 & MBS & areia muito fina \\
\hline & Meio & 0,00 & 0,06 & 0,06 & 0,10 & 4,48 & 91,87 & 1,71 & 1,71 & 3,52 & MBS & areia muito fina \\
\hline & Fundo & 0,00 & 0,00 & 0,03 & 0,03 & 3,61 & 91,23 & 3,40 & 1,70 & 3,56 & MBS & areia muito fina \\
\hline \multirow{3}{*}{6} & Superfície & 0,00 & 0,12 & 0,12 & 0,09 & 9,84 & 70,38 & 4,86 & 14,57 & 4,52 & POS & silte grosso \\
\hline & Meio & 0,07 & 0,14 & 0,13 & 0,23 & 10,45 & 69,20 & 3,30 & 16,49 & 4,82 & MPS & silte grosso \\
\hline & Fundo & 0,00 & 0,03 & 0,16 & 0,23 & 9,98 & 65,28 & 4,86 & 19,46 & 4,87 & MPS & silte grosso \\
\hline \multirow{3}{*}{7} & Superfície & 0,00 & 0,03 & 0,06 & 0,10 & 9,71 & 83,42 & 3,34 & 3,34 & 3,50 & BMS & areia muito fina \\
\hline & Meio & 0,00 & 0,00 & 0,06 & 0,17 & 10,61 & 83,99 & 1,72 & 3,44 & 3,48 & BMS & areia muito fina \\
\hline & Fundo & 0,00 & 0,00 & 0,06 & 0,10 & 10,94 & 80,49 & 5,05 & 3,36 & 3,49 & MOS & areia muito fina \\
\hline \multirow{3}{*}{8} & Superfície & 0,14 & 0,92 & 1,10 & 1,27 & 31,52 & 65,05 & 0,00 & 0,00 & 3,09 & BMS & areia muito fina \\
\hline & Meio & 0,10 & 1,10 & 1,20 & 1,20 & 30,63 & 65,77 & 0,00 & 0,00 & 3,08 & BMS & areia muito fina \\
\hline & Fundo & 0,14 & 0,93 & 1,09 & 1,20 & 31,40 & 65,23 & 0,00 & 0,00 & 3,08 & BMS & areia muito fina \\
\hline \multirow{3}{*}{9} & Superfície & 0,00 & 0,07 & 0,14 & 0,17 & 7,07 & 74,49 & 6,58 & 11,51 & 4,09 & POS & silte grosso \\
\hline & Meio & 0,00 & 0,03 & 0,10 & 0,20 & 8,29 & 69,54 & 5,04 & 16,79 & 5,01 & MPS & silte médio \\
\hline & Fundo & 0,00 & 0,00 & 0,10 & 0,24 & 8,32 & 64,93 & 13,21 & 13,21 & 4,81 & POS & silte grosso \\
\hline \multirow{3}{*}{10} & Superfície & 0,21 & 0,55 & 0,69 & 0,90 & 42,04 & 55,62 & 0,00 & 0,00 & 3,05 & MBS & areia muito fina \\
\hline & Meio & 5,91 & 2,71 & 2,20 & 1,75 & 41,23 & 46,18 & 0,00 & 0,00 & 2,94 & MOS & areia fina \\
\hline & Fundo & 6,22 & 3,06 & 1,87 & 1,40 & 36,27 & 42,69 & 1,70 & 6,80 & 3,06 & POS & areia muito fina \\
\hline \multirow{3}{*}{11} & Superfície & 1,54 & 1,27 & 1,30 & 1,44 & 12,52 & 66,54 & 8,55 & 6,84 & 3,52 & POS & areia muito fina \\
\hline & Meio & 4,74 & 3,93 & 2,35 & 2,22 & 15,43 & 59,54 & 6,72 & 5,04 & 3,30 & POS & areia muito fina \\
\hline & Fundo & 4,75 & 4,10 & 2,58 & 2,44 & 15,79 & 60,17 & 6,78 & 3,39 & 3,27 & POS & areia muito fina \\
\hline & Superfície & 0,00 & 0,00 & 0,00 & 0,00 & 0,00 & 3,81 & 77,77 & 18,42 & 6,80 & POS & silte fino \\
\hline 12 & Meio & 0,00 & 0,00 & 0,00 & 0,00 & 0,00 & 3,29 & 71,26 & 25,45 & 7,13 & POS & silte muito fino \\
\hline & Fundo & 0,00 & 0,00 & 0,00 & 0,00 & 0,00 & 3,41 & 56,92 & 39,67 & 7,31 & POS & silte muito fino \\
\hline & Superfície & 0,00 & 0,00 & 0,00 & 0,10 & 0,36 & 88,15 & 4,88 & 6,51 & 3,71 & MOS & areia muito fina \\
\hline 13 & Meio & 0,00 & 0,00 & 0,00 & 0,00 & 0,20 & 93,05 & 3,37 & 3,37 & 3,68 & MBS & areia muito fina \\
\hline & Fundo & 0,00 & 0,00 & 0,00 & 0,06 & 0,20 & 91,40 & 1,67 & 6,67 & 3,68 & MOS & areia muito fina \\
\hline & Superfície & 0,00 & 0,17 & 0,20 & 0,72 & 52,85 & 45,94 & 0,00 & 0,00 & 3,04 & BMS & areia muito fina \\
\hline 14 & Meio & 0,44 & 0,37 & 0,44 & 0,77 & 48,21 & 46,39 & 1,69 & 1,69 & 3,09 & BMS & areia muito fina \\
\hline & Fundo & 0,03 & 0,14 & 0,20 & 0,67 & 46,95 & 45,31 & 1,68 & 5,03 & 3,16 & POS & areia muito fina \\
\hline & Superfície & 0,10 & 0,41 & 0,45 & 1,00 & 49,98 & 48,06 & 0,00 & 0,00 & 3,01 & MBS & areia muito fina \\
\hline 15 & Meio & 0,24 & 0,82 & 0,82 & 1,30 & 49,93 & 46,89 & 0,00 & 0,00 & 2,99 & BMS & areia fina \\
\hline & Fundo & 0,34 & 1,00 & 0,97 & 1,14 & 49,50 & 47,06 & 0,00 & 0,00 & 3,01 & BMS & areia muito fina \\
\hline & Superfície & 0,03 & 0,14 & 0,06 & 0,31 & 4,00 & 92,03 & 1,71 & 1,71 & 3,50 & MBS & areia muito fina \\
\hline 16 & Meio & 0,00 & 0,10 & 0,10 & 0,34 & 3,33 & 91,06 & 1,69 & 3,37 & 3,51 & MOS & areia muito fina \\
\hline & Fundo & 0,03 & 0,10 & 0,10 & 0,36 & 3,82 & 90,55 & 1,68 & 3,35 & 3,51 & MOS & areia muito fina \\
\hline & \begin{tabular}{|l|} 
Superfície \\
\end{tabular} & 0,00 & 0,10 & 0,17 & 0,50 & 15,19 & 79,03 & 0,00 & 5,01 & 3,33 & MOS & areia muito fina \\
\hline 17 & Meio & 0,07 & 0,10 & 0,17 & 0,46 & 15,32 & 78,09 & 0,00 & 4,98 & 3,33 & BMS & areia muito fina \\
\hline & Fundo & 0,03 & 0,10 & 0,14 & 0,50 & 15,38 & 78,90 & 1,66 & 3,31 & 3,33 & BMS & areia muito fina \\
\hline & Superfície & 0,00 & 0,03 & 0,06 & 0,27 & 3,92 & 63,86 & 10,06 & 21,79 & 5,17 & MPS & silte médio \\
\hline 18 & Meio & 0,00 & 0,00 & 0,03 & 0,29 & 2,92 & 41,60 & 27,58 & 27,58 & 5,54 & MPS & silte médio \\
\hline & Fundo & 0,00 & 0,00 & 0,06 & 0,13 & 1,69 & 65,87 & 15,26 & 16,96 & 5,15 & POS & silte médio \\
\hline & Superfície & 0,00 & 0,17 & 0,21 & 1,38 & 28,66 & 69,59 & 0,00 & 0,00 & 3,12 & MBS & areia muito fina \\
\hline 19 & Meio & 0,03 & 0,13 & 0,24 & 1,41 & 28,68 & 69,50 & 0,00 & 0,00 & 3,11 & MBS & areia muito fina \\
\hline & Fundo & 0,13 & 0,27 & 0,37 & 1,58 & 27,30 & 65,39 & 0,00 & 4,97 & 3,14 & BMS & areia muito fina \\
\hline & Superfície & 0,31 & 0,41 & 0,58 & 0,69 & 6,15 & 83,27 & 3,43 & 5,15 & 3,60 & MOS & areia muito fina \\
\hline 20 & Meio & 0,17 & 0,40 & 0,68 & 0,78 & 6,42 & 81,34 & 3,40 & 6,80 & 3,61 & MOS & areia muito fina \\
\hline & Fundo & 0,17 & 0,51 & 0,74 & 0,87 & 6,86 & 80,77 & 3,36 & 6,72 & 3,61 & POS & areia muito fina \\
\hline & Superfície & 0,50 & 0,14 & 0,19 & 0,19 & 1,60 & 1,51 & 27,40 & 68,49 & 7,91 & POS & silte muito fino \\
\hline 21 & Meio & 0,95 & 0,40 & 0,56 & 0,55 & 1,44 & 1,21 & 31,09 & 63,81 & 7,79 & POS & silte muito fino \\
\hline & Fundo & 0,76 & 0,43 & 0,79 & 0,93 & 1,68 & 1,39 & 51,14 & 42,89 & 7,24 & POS & silte muito fino \\
\hline
\end{tabular}



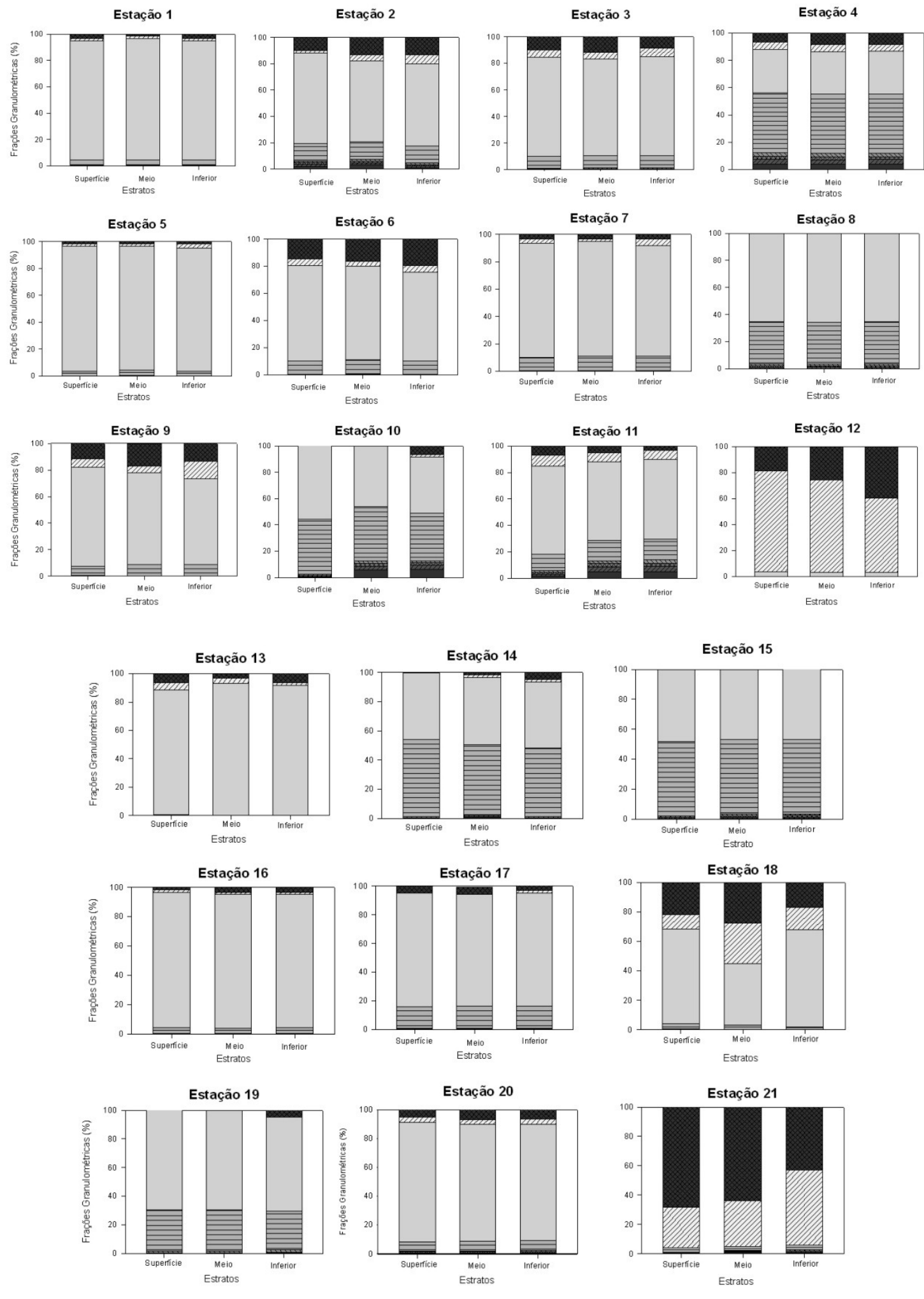

Figura 8 - Distribuição das frações Granulométricas nos diferentes estratos (superfície, meio e inferior) das amostras de sedimento coletadas na campanha de verão nas estações da plataforma continental, entre São Sebastião e Peruíbe, SP. GRN: grânulo, AMG: areia muito grossa, AG: areia grossa, AM: areia média; AF: areia fina, AMF: areia muito fina, SIL: silte e ARG: argila. 
Tabela 5- Porcentagens médias de matéria orgânica (MO\%) e carbonato $\left(\mathrm{CaCO}_{3}\right)$ nos sedimentos coletados na plataforma continental entre São Sebastião e Peruíbe, SP para as duas campanhas.

\begin{tabular}{|c|c|c|c|c|c|c|c|c|}
\hline \multirow{3}{*}{ Estação } & \multicolumn{8}{|c|}{ \% Matéria Orgânica } \\
\hline & \multicolumn{4}{|c|}{ INVERNO / 2005} & \multicolumn{4}{|c|}{ VERÃO / 2006} \\
\hline & Superfície & Meio & Fundo & Média & Superfície & Meio & Fundo & Média \\
\hline 1 & 1,76 & 12,94 & 1,75 & 5,48 & 1,16 & 1,37 & 1,20 & 1,24 \\
\hline 2 & 2,16 & 3,65 & 3,58 & 3,13 & 5,47 & 8,00 & 15,95 & 9,81 \\
\hline 3 & 3,67 & 3,78 & 2,93 & 3,46 & 2,74 & 2,97 & 2,40 & 2,70 \\
\hline 4 & 2,31 & 2,47 & 4,20 & 2,99 & 2,82 & 3,72 & 3,99 & 3,51 \\
\hline 5 & 1,22 & 1,31 & 1,88 & 1,47 & 4,01 & 1,03 & 1,36 & 2,14 \\
\hline 6 & 1,10 & 1,59 & 1,41 & 1,37 & 8,54 & 11,46 & 7,18 & 9,06 \\
\hline 7 & 2,34 & 1,20 & 8,94 & 4,16 & 5,29 & 10,83 & 4,91 & 7,01 \\
\hline 8 & 0,95 & 1,51 & 1,12 & 1,19 & 0,93 & 2,39 & 0,57 & 1,30 \\
\hline 9 & 1,62 & 4,05 & 3,43 & 3,03 & 6,16 & 6,61 & 7,11 & 6,63 \\
\hline 10 & 0,84 & 0,80 & 1,45 & 1,03 & 1,04 & 0,91 & 3,09 & 1,68 \\
\hline 11 & 2,02 & 2,17 & 2,15 & 2,11 & 2,69 & 2,16 & 2,53 & 2,46 \\
\hline 12 & 8,96 & 8,04 & 9,19 & 8,73 & 12,28 & 13,04 & 8,63 & 11,32 \\
\hline 13 & 2,20 & 3,34 & 2,29 & 2,61 & 4,56 & 10,39 & 21,64 & 12,20 \\
\hline 14 & 0,91 & 0,85 & 1,23 & 1,00 & 0,56 & 0,89 & 1,20 & 0,88 \\
\hline 15 & 0,92 & 0,88 & 0,92 & 0,91 & 1,03 & 0,98 & 2,28 & 1,43 \\
\hline 16 & 1,09 & 1,06 & 1,20 & 1,12 & 1,08 & 1,09 & 1,14 & 1,10 \\
\hline 17 & 1,24 & 0,99 & 1,08 & 1,10 & 2,22 & 1,28 & 1,16 & 1,55 \\
\hline 18 & 1,04 & 1,53 & 1,49 & 1,35 & 7,26 & 14,48 & 7,93 & 9,89 \\
\hline 19 & 2,38 & 1,80 & 1,11 & 1,76 & 1,02 & 1,21 & 1,22 & 1,15 \\
\hline 20 & 1,51 & 1,96 & 1,79 & 1,75 & 1,47 & 2,73 & 3,88 & 2,69 \\
\hline 21 & 6,78 & 6,08 & 7,29 & 6,71 & 17,57 & 10,58 & 9,49 & 12,54 \\
\hline \multirow{3}{*}{ Estação } & \multicolumn{8}{|c|}{$\%$ Carbonato } \\
\hline & \multicolumn{4}{|c|}{ INVERNO / 2005} & \multicolumn{4}{|c|}{ VERÃO / 2006} \\
\hline & Superfície & Meio & Fundo & Média & Superfície & Meio & Fundo & Média \\
\hline 1 & 5,29 & 10,30 & 4,50 & 6,70 & 4,30 & 3,98 & 4,50 & 4,26 \\
\hline 2 & 9,90 & 6,70 & 6,30 & 7,63 & 4,60 & 7,65 & 6,70 & 6,32 \\
\hline 3 & 8,68 & 10,28 & 10,00 & 9,65 & 9,40 & 9,00 & 8,10 & 8,83 \\
\hline 4 & 19,76 & 17,41 & 21,00 & 19,39 & 18,50 & 23,54 & 21,55 & 21,20 \\
\hline 5 & 4,80 & 4,80 & 5,10 & 4,90 & 4,50 & 4,59 & 5,29 & 4,79 \\
\hline 6 & 2,30 & 2,30 & 2,40 & 2,33 & 3,00 & 3,65 & 3,45 & 3,37 \\
\hline 7 & 3,10 & 2,75 & 2,80 & 2,88 & 2,20 & 2,10 & 2,15 & 2,15 \\
\hline 8 & 6,40 & 9,09 & 8,26 & 7,92 & 6,30 & 6,00 & 7,49 & 6,60 \\
\hline 9 & 2,80 & 4,55 & 5,15 & 4,17 & 3,20 & 3,40 & 3,55 & 3,38 \\
\hline 10 & 5,86 & 8,83 & 10,49 & 8,39 & 5,13 & 16,83 & 20,79 & 14,25 \\
\hline 11 & 20,44 & 25,39 & 23,45 & 23,09 & 15,62 & 23,40 & 30,80 & 23,27 \\
\hline 12 & 33,17 & 22,41 & 22,47 & 26,02 & 30,04 & 27,43 & 25,95 & 27,81 \\
\hline 13 & 3,00 & 3,50 & 2,90 & 3,13 & 2,65 & 2,45 & 2,55 & 2,55 \\
\hline 14 & 3,00 & 3,20 & 3,71 & 3,30 & 2,99 & 4,20 & 4,12 & 3,77 \\
\hline 15 & 3,33 & 4,92 & 7,12 & 5,12 & 3,70 & 4,70 & 4,66 & 4,35 \\
\hline 16 & 3,90 & 3,99 & 4,61 & 4,17 & 5,10 & 5,10 & 5,20 & 5,13 \\
\hline 17 & 3,78 & 4,62 & 4,98 & 4,46 & 4,50 & 4,10 & 4,50 & 4,37 \\
\hline 18 & 2,35 & 2,30 & 2,10 & 2,25 & 4,15 & 5,20 & 3,90 & 4,42 \\
\hline 19 & 3,41 & 3,60 & 3,48 & 3,50 & 3,99 & 4,20 & 4,45 & 4,21 \\
\hline 20 & 9,03 & 11,76 & 11,36 & 10,72 & 9,30 & 9,43 & 10,06 & 9,60 \\
\hline 21 & 15,30 & 15,77 & 15,99 & 15,69 & 27,04 & 23,75 & 27,27 & 26,02 \\
\hline
\end{tabular}



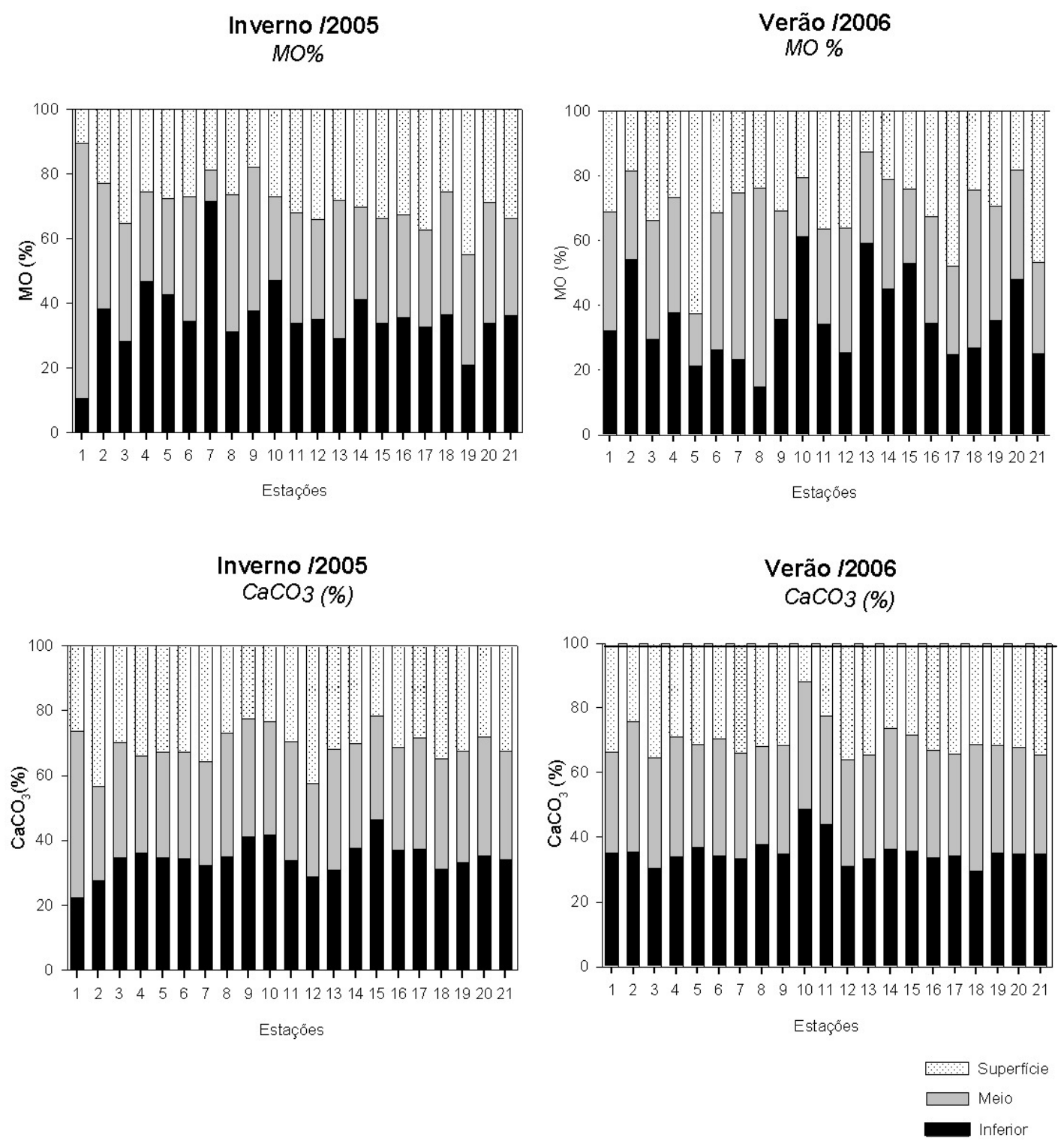

Figura 9 - Porcentagens médias de matéria orgânica $(\mathrm{MO} \%)$ e carbonato $\left(\mathrm{CaCO}_{3}\right)$ contidas nos diferentes estratos da coluna sedimentar das amostras coletadas na plataforma continental entre São Sebastião e Peruíbe, SP para as duas campanhas. 


\subsection{Dados biológicos}

\subsubsection{Composição Específica}

Para as duas campanhas foram identificadas 41 espécies e 19 morfoespécies pertencentes à Ordem Amphipoda. Deste total, 29 espécies e 15 morfoespécies são da Subordem Gammaridea e 12 espécies e 4 morfoespécies da Subordem Corophiidea, totalizando 43 gêneros e 24 famílias. No inverno foram registradas 39 espécies e 16 morfoespécies e no verão 37 espécies e 17 morfoespécies.

As 19 morfoespécies foram identificadas a nível genérico e são referidas como sp. ou sp.n., quando constatadas serem novas espécies. Estas últimas pertencentes a seis gêneros: Ampelisca, Metharpinia, Urothoe, Pseudomegamphopus, Cheirophotis e Cerapus. Destas, Cheirophotis neotropicalis e Cerapus jonsoni já foram descritas e os artigos científicos publicados (VALÉRIO-BERARDO et al., 2007 e 2008). As quatro espécies restantes serão objeto de trabalhos posteriores.

Entre as 24 famílias identificadas Ampeliscidae apresentou o maior número de espécies (10). Houve um alto número de gêneros presentes (34) representados por uma única espécie. Ampelisca sp.n. 1, Ampelisca sp.n. 2, Ampithoe ramondi, Ceradocus sp., Dulichiella anisochir, Westwoodilla rectirostris e Syrrhoe crenulata ocorreram apenas na campanha de inverno, enquanto Monocorophium acherusicum, Parametopella ninis, Corophiidae cf. Leptocheirus, Kamakidae cf. Aorcho e Eusirus sp. ocorreram somente na campanha de verão.

A listagem das espécies obtidas no presente trabalho é dada a seguir. A classificação taxonômica dos anfípodes da Subordem Gammaridea foi baseada em Barnard \& Karaman (1991) e da Subordem Corophiidea em Myers \& Lowry (2003).

Subfilo Crustacea Brünnich, 1772

Superordem Peracarida Calman, 1904

Ordem Amphipoda Latreille, 1816

Subordem Gammaridea Latreille, 1802

Família Ampeliscidae Costa, 1857

Ampelisca sp.n. 1

Ampelisca sp.n. 2

Ampelisca brevisimulata J. L. Barnard, 1954

Ampelisca cristata Holmes, 1908

Ampelisca moreirai Valério-Berardo \& Wakabara, 2006 
Ampelisca paria Barnard \& Agard, 1986

Ampelisca pugetica Stimpson, 1864

Ampelisca rodriguesi Valério-Berardo, 2005

Ampelisca romigi J. L. Barnard, 1954

Ampelisca subtropicalis Valério-Berardo, 2005

Família Amphilochidae Boeck, 1871

Gitanopsis sp.

Família Dexaminidae Leach, 1814

Kamehatylus sp.

Família Eusiridae Stebbing, 1888

Eusirus sp.

Família Liljeborgiidae Stebbing, 1899

Liljeborgia dubia (Haswell, 1879)

Liljeborgia quinquedentata Schellenberg, 1931

Listriella titinga Wakabara et al., 1988

Superfamília Lysianassoidea Dana, 1849

Família Lysianassidae Dana, 1849

Prachynella sp.

Subfamília Tryphosinae Lowry \& Stoddart, 1997

Tryphosella sp. 1

Tryphosella sp. 2

Família Melitidae Bousfield, 1973

Ceradocus sp.

Dulichiella anisochir (Kroyer, 1845)

Giberosus myersi (McKinney, 1980)

Maera sp.

Resupinus coloni (Thomas and J. L. Barnard, 1986)

Família Oedicerotidae Liljeborg, 1865

Monoculodes nyei Shoemaker, 1933

Paramonoculopsis acuta Alonso, 1997

Oediceroides cinderella Stebbing, 1888

Synchelidium americanum Bousfield, 1973

Westwoodilla rectirostris (Della Valle, 1893)

Família Pardaliscidae Boeck, 1871

Pardaliscidae cf. Halicoides

Família Phoxocephalidae Sars, 1891 
Heterophoxus videns K.H. Barnard, 1930

Metharpinia sp.n.

Metharpina aff. iado Alonso de Pina, 2003

Microphoxus moaresi Bustamante, 2002

Pseudoharpinia dentata Schellenberg, 1931

Família Platyischnopidae Barnard \& Drummond, 1979

Eudevenopus gracilipes (Schellenberg, 1931)

Tiburonella viscana (J. L. Barnard, 1964)

Família Synopiidae Dana, 1853

Syrrhoe crenulata Goes, 1866

Tiron biocellata J. L.Barnard, 1962

Tiron tropakis J. L. Barnard, 1972

Família Stenothoidae Boeck, 1871

Parametopella ninis J. L. Barnard, 1962

Superfamília Haustorioidea

Família Urohaustoriidae

Huerpa sp.

Família Urothoidae Dana, 1852

Carangolia sp.

Urothoe sp.n.

Subordem Corophiidea Leach, 1814

InfraOrdem Corophiida Leach, 1814

Superfamília Aoroidea Stebbing, 1899

Família Aoridae Stebbing, 1899

Lembos sp.

Superfamília Corophiidea Leach, 1814

Família Ampithoidae Stebbing, 1899

Subfamília Ampithoinae Boeck, 1871

Ampithoe ramondi Audouin, 1826

Família Corophiidae Leach, 1814

Subfamília Corophiinae Leach, 1814

Tribo Corophiini Leach, 1814

Monocorophium acherusicum (Costa, 1857)

Tribo Haplocheirini Myers \& Lowry, 2003

Corophiidae cf. Leptocheirus

Subfamília Protomedeiinae Myers \& Lowry, 2003 
Cheirophotis megacheles (Giles,1885)

Cheirophotis neotropicalis Valério-Berardo, de Souza \& Rodrigues, 2007

Infraordem Caprellida Leach, 1814

Superfamília Caprelloidea Leach, 1814

Família Caprellidae Leach, 1814

Paracaprella pusilla Mayer, 1890

Paracaprella tenuis Mayer, 1903

Família Podoceridae Leach, 1814

Podocerus brasiliensis (Dana, 1853)

Superfamília Neomegamphoidea Myers, 1981

Família Neomegamphopidae Myers, 1981

Pseudomegamphopus sp.n.

Pseudomegamphopus barnardi Myers, 1968

Superfamília Photoidea Boeck, 1872

Família Ischyroceridae Stebbing, 1899

Subfamília Ischyrocerinae Stebbing, 1899

Tribo Siphonoecetini Just, 1983

Cerapus jonsoni Valério-Berardo, de Souza \& Rodrigues, 2008

Família Kamakidae Myers \& Lowry, 2003

Subfamília Aorchinae Myers \& Lowry, 2003

Kamakidae cf. Aorcho

Família Photidae Boeck, 1871

Ampelisciphotis podophthalma J. L. Barnard, 1958

Photis brevipes Shoemaker, 1942

Photis longicaudata (Bate and Westwood, 1863)

\subsubsection{Classificação funcional}

Com base na literatura (BIERNBAUM, 1979; VALÉRIO-BERARDO, 1992; DAUBY et al., 2001; DE BROYER et al., 2003 e YU et al., 2003) as espécies foram classificadas funcionalmente, de acordo com seu grupo trófico e locomoção. Apenas a espécie de Kamakidae cf. Aorcho não foi classificada quanto ao grupo trófico (Tabela 6).

Vinte e uma espécies de organismos de infauna foram obtidas nas duas campanhas, e dentro deste grupo podemos citar como sendo as mais abundantes: Giberosus myersi, Resupinus coloni, Monoculodes nyei, Synchelidium americanum, Heterophoxus videns, Microphoxus moaresi, Eudevenopus gracilipes e Urothoe sp.n. Dentro 
dos organismos de infauna foram encontrados seis grupos tróficos: suspensívoro, carnívoro, necrófago, comensal, detritívoros de subsuperfície e detritívoros cavadores, sendo detritívoros os mais abundantes. Detritívoros de subsuperfície permanecem nos primeiros centímetros do substrato, como é o caso das espécies dos gêneros Monoculodes e Synchelidium, que exibem alta mobilidade e comportamento que pode variar entre natação sobre o sedimento e enterramento na subsuperfície do sedimento. Detritívoros cavadores compreendem as espécies das Famílias Phoxocephalidae, Urothoidae e Urohaustoriidae, e têm a capacidade de alcançar estratos mais profundos, podendo construir galerias.

Dezesseis espécies foram classificadas como epifaunais vagéis, sendo a maioria de vida livre, as demais foram classificadas como inquilinas. As espécies mais representativas foram: Gitanopsis sp., Liljeborgia dubia e Liljeborgia quinquedentata. Dentro das espécies epifaunais vagéis foram encontrados seis grupos tróficos: suspensívoro, carnívoro, detritívoro de subsuperfície, comensais, necrófagos e herbívoros, sendo os carnívoros os mais abundantes. A maioria dos organismos classificados como epifauna vágil são espécies com alta mobilidade e isto acarreta um poder maior de natação, fato raro nos organismos infaunais, mencionados anteriormente.

No presente estudo foram encontradas vinte e uma espécies tubícolas. Oito espécies foram classificadas como tubícolas de infauna, todas elas pertencentes ao gênero Ampelisca (Família Ampeliscidae). Essas espécies podem mudar seu grupo trófico de suspensívoras para detritívoras de subsuperfície segundo a disponibilidade de alimento no ambiente. As demais, na sua maioria pertencentes à Superfamília Corophiidea, foram classificadas em tubícolas de epifauna e suspensívoras.

No presente estudo os oportunistas de tubos estão representados por apenas duas espécies, Tiron biocellata e Podocerus brasiliensis. Esta última pertence a Superfamília Corophiidea, grupo onde a maior parte dos representantes tem a capacidade de construir tubos, sendo porém uma exceção por não apresentar glândulas nos pereópodos. Esta espécie, portanto, não consegue construir tubos e como adaptação desenvolveu o hábito de tornar-se inquilino de tubos de outros organismos. Tiron biocellata, embora seja um Gammaridea, que normalmente tem vida livre, também apresenta essa adaptação, podendo ser encontrado em tubos de outros organismos, como poliquetos (Tabela 6).

Photis longicaudata é tubícola de epifauna; contudo, durante o processo de triagem esta espécie foi encontrada em tubos por ela construídos dentro de conchas vazias de gastrópodes ou, mais raramente, de scafópodes. Por muitas vezes, ao se abrir esses tubos, 
encontrou-se dois indivíduos, possivelmente fêmea e macho. Deve-se acrescentar que em algumas situações essas conchas eram co-habitadas por P. longicaudata e sipunculídeos, e nesses casos, os organismos utilizavam diferentes aberturas para se alimentar.

Tabela 6 - Classificação ecológica (ocupação, mobilidade e grupo trófico) das espécies de anfípodes encontrados na plataforma continental entre São Sebastião e Peruíbe, SP. S: Suspensívoro, DS: Detritívoro de Subsuperficie, DC: Detritívoro Cavador, C: Carnívoro; N: Necrofágo, Co: Comensal e H: Herbívoro.

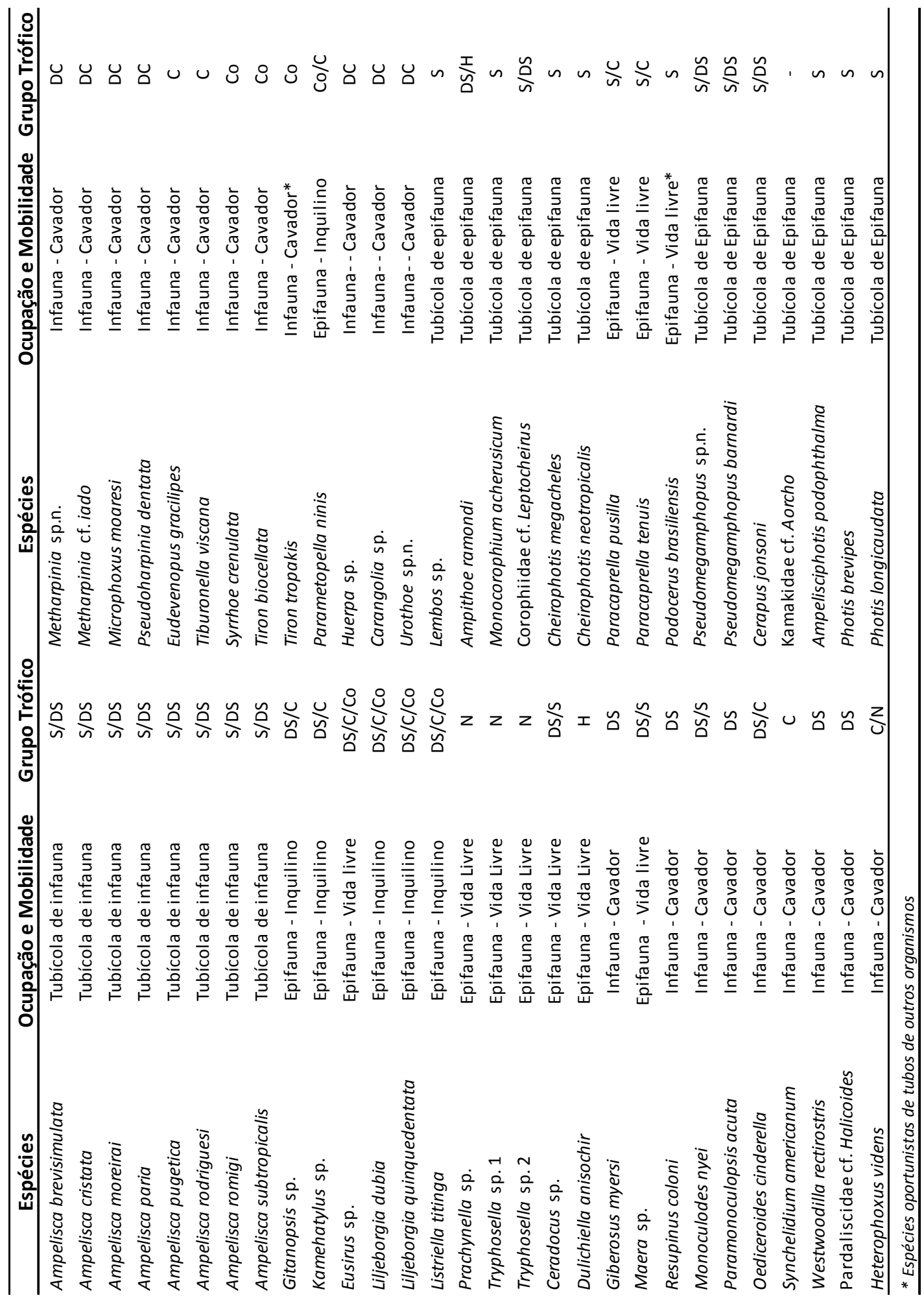




\subsubsection{Freqüência de Ocorrência Relativa}

$\mathrm{Na}$ tabela 7 encontram-se as espécies divididas em cinco categorias diferentes, segundo a sua freqüência de ocorrência relativa (FOR): Muito freqüente (MF - $\geq 30 \%$ ); Freqüente (F - $\geq 20-<30 \%)$; Pouco freqüente (PF - $\geq 10-<20 \%)$; Rara (R - $\geq 5-<10 \%)$ e Muito rara (MR - <5\%).

Para a campanha de inverno dez espécies foram consideradas muito freqüentes: Microphoxus moaresi, Ampelisca paria, Pseudomegamphopus sp.n., Ampelisca brevisimulata, Ampelisca moreirai, Eudevenopus gracilipes, Liljeborgia quinquedentata, Tiron biocellata, Monoculodes nyei e Resupinus coloni e nove freqüentes: Ampelisca cristata, Ampelisca pugetica, Cheirophotis neotropicalis, Heterophoxus videns, Liljeborgia dubia, Pseudoharpinia dentata, Liljeborgia dubia, Urothoe sp.n. e Maera sp.. Além disso, foram registradas 15 espécies pouco freqüentes, 10 raras e 11 muito raras (Tabela 7).

Na campanha de verão dezessete espécies foram consideradas muito freqüentes: Microphoxus moaresi, Resupinus coloni, Photis brevipes, Liljeborgia quinquedentata, Lembos sp., Gitanopsis sp., Ampelisca paria, Paracaprella tenuis, Photis longicaudata, Eudevenopus gracilipes, Tryphosella sp. 2, Ampelisca brevisimulata, Parametopella ninis, Heterophoxus videns, Paramonoculopsis acuta, Pseudomegamphopus sp.n. e Ampelisca cristata e seis espécies freqüentes: Monoculodes nyei, Ampelisca moreirai, Urothoe sp.n., Tiron tropakis, Tiron biocellata, Ampelisca pugetica. Além disso, foram regitradas 9 espécies pouco freqüentes, 8 raras e 11 muito raras (Tabela 7).

Como pode ser observado na tabela 7 , no inverno as categorias que englobam um maior número de espécies foram as Muito Raras e Raras (MR e R), no total 21 espécies. A maioria destas não apresentaram alta abundância, sendo a única exceção Metharpinia sp.n., na estação 20. No verão, diferentemente do ocorrido no inverno, as categorias Muito Freqüente e Frequente (MF e F) apresentaram o maior número de espécies (23), todas com alta abundância. 
Tabela 7 - Distribuição batimétrica, Freqüência de Ocorrência Relativa (FOR) e categorias das espécies em relação às freqüências de todas as espécies coletadas nas duas campanhas (inverno e verão). MF: Muito Freqüente ( $\geq 30 \%)$; F: Freqüente ( $\geq 20-<30 \%)$; PF: Pouco Freqüente $(\geq 10-<20 \%)$; R: Rara $(\geq 5-<10 \%)$ e MR: Muito Rara $(<5 \%)$.

\begin{tabular}{|c|c|c|c|c|c|c|}
\hline & \multicolumn{2}{|c|}{ Profundidade (m) } & \multicolumn{2}{|c|}{ FOR (\%) } & \multicolumn{2}{|c|}{ Categoria } \\
\hline & Inverno/2005 & Verão/2006 & Inverno/2005 & Verão/2006 & Inverno/2005 & Verão/2006 \\
\hline Ampelisca sp.n. 1 & $34,7-58$ & / & 14,3 & / & PF & / \\
\hline Ampelisca sp.n. 2 & 58 & / & 4,8 & / & MR & / \\
\hline Ampelisca brevisimulata & $26-58$ & $26-58$ & 33,3 & 38,1 & MF & MF \\
\hline Ampelisca cristata & $26-85$ & $26-85$ & 28,6 & 33,3 & $\mathrm{~F}$ & MF \\
\hline Ampelisca moreirai & $14-85$ & $26-85$ & 33,3 & 28,6 & MF & $\mathrm{F}$ \\
\hline Ampelisca paria & $14-32,5$ & $14-32,5$ & 66,7 & 47,6 & MF & MF \\
\hline Ampelisca pugetica & $27-96$ & $27-96$ & 28,6 & 23,8 & $\mathrm{~F}$ & $\mathrm{~F}$ \\
\hline Ampelisca rodriguesi & $50-85$ & $50-85$ & 14,3 & 9,5 & PF & $\mathrm{R}$ \\
\hline Ampelisca romigi & $19-96$ & $19-96$ & 14,3 & 19 & $\mathrm{PF}$ & PF \\
\hline Ampelisca subtropicalis & 58 & 58 & 4,8 & 4,8 & MR & $\mathrm{MR}$ \\
\hline Gitanopsis sp. & $26-85$ & $26-85$ & 19 & 47,6 & $\mathrm{PF}$ & MF \\
\hline Ampithoe ramondi & 29 & / & 4,8 & / & MR & / \\
\hline Lembos sp. & $27-97$ & $27-97$ & 19 & 52,4 & PF & MF \\
\hline Kamakidae cf. Aorcho & / & $34-85$ & / & 4,8 & / & MR \\
\hline Cheirophotis megacheles & $26-34,7$ & $26-34,7$ & 9,5 & 9,5 & $\mathrm{R}$ & $\mathrm{R}$ \\
\hline Cheirophotis neotropicalis & $15-56$ & $15-56$ & 28,6 & 9,5 & $\mathrm{~F}$ & $\mathrm{R}$ \\
\hline Corophiidae cf. Leptocheirus & / & 51 & / & 4,8 & / & MR \\
\hline Monocorophium acherusicum & / & 34 & / & 4,8 & / & $\mathrm{MR}$ \\
\hline Kamehatylus sp. & $14-29$ & $14-29$ & 14,3 & 9,5 & PF & $\mathrm{R}$ \\
\hline Eusirus sp. & / & 57 & / & 4,8 & / & MR \\
\hline Cerapus jonsoni & 58 & / & 4,8 & / & $\mathrm{R}$ & / \\
\hline Liljeborgia dubia & $20,7-58$ & $20,7-58$ & 28,6 & 4,8 & $\mathrm{~F}$ & $\mathrm{MR}$ \\
\hline Liljeborgia quinquedentata & $26-32,5$ & $16,1-58$ & 33,3 & 25,4 & MF & MF \\
\hline Listriella titinga & $32-56$ & $32-56$ & 9,5 & 4,8 & $\mathrm{R}$ & $\mathrm{MR}$ \\
\hline Prachynella sp. & 58 & 58 & 4,8 & 4,8 & MR & MR \\
\hline Tryphosella sp. 1 & $20-85$ & $20-85$ & 14,3 & 14,3 & PF & PF \\
\hline Tryphosella sp. 2 & $26-85$ & $26-85$ & 4,8 & 38,1 & $\mathrm{MR}$ & MF \\
\hline Ceradocus sp. & 85 & / & 4,8 & / & MR & / \\
\hline Dulichiella anisochir & 58 & / & 4,8 & / & MR & / \\
\hline Giberosus myersi & $20-34$ & $20-34$ & 19 & 4,8 & $\mathrm{PF}$ & MR \\
\hline Maera sp. & $29-97$ & 29-97 & 23,8 & 4,8 & $\mathrm{~F}$ & MR \\
\hline Resupinus coloni & $26-85$ & $14-85$ & 33,3 & 61,9 & MF & MF \\
\hline Pseudomengamphopus sp.n. & $16,5-34$ & $15-96$ & 33,3 & 33,3 & MF & MF \\
\hline Pseudomegamphopus barnardi & $16-85$ & $16-85$ & 9,5 & 14,3 & $\mathrm{R}$ & PF \\
\hline Monoculodes nyei & $28,8-32,5$ & $26-32,5$ & 33,3 & 28,6 & MF & $\mathrm{F}$ \\
\hline Paramonoculopsis acuta & $50-56$ & $15-51$ & 9,5 & 33,3 & $\mathrm{R}$ & MF \\
\hline Oediceroides cinderella & $13-16$ & 56 & 14,3 & 4,8 & PF & MR \\
\hline Synchelidium americanum & $28,8-58$ & $32-51$ & 19 & 14,3 & PF & $\mathrm{PF}$ \\
\hline Westwoodilla rectirostris & 85 & / & 4,8 & / & MR & / \\
\hline Pardaliscidae cf. Halicoides & $29-56$ & $29-56$ & 4,8 & 9,5 & MR & $\mathrm{R}$ \\
\hline Ampelisciphotis podophthalma & $56-85$ & $56-85$ & 9,5 & 9,5 & $\mathrm{R}$ & $\mathrm{R}$ \\
\hline Photis brevipes & $26-57$ & $26-57$ & 28,6 & 47,6 & $F$ & MF \\
\hline Photis longicaudata & $15-57$ & $15-57$ & 9,5 & 42,9 & $\mathrm{R}$ & MF \\
\hline Heterophoxus videns & $28-96$ & $28-96$ & 28,6 & 33,3 & $\mathrm{~F}$ & MF \\
\hline Metharpinia sp.n. & $28-58$ & $28-58$ & 19 & 9,5 & $\mathrm{PF}$ & $\mathrm{R}$ \\
\hline Metharpina cf. iado & $36-85$ & $32-85$ & 9,5 & 14,3 & $\mathrm{R}$ & PF \\
\hline Microphoxus moaresi & $14-85$ & $14-85$ & 71,4 & 81 & MF & MF \\
\hline Pseudoharpina dentata & $28-97$ & $28-97$ & 28,6 & 19 & $\mathrm{~F}$ & PF \\
\hline
\end{tabular}


Tabela 7 - Continuação

\begin{tabular}{|c|c|c|c|c|c|c|}
\hline & \multicolumn{2}{|c|}{ Profundidade (m) } & \multicolumn{2}{|c|}{ FOR (\%) } & \multicolumn{2}{|c|}{ Categoria } \\
\hline & Inverno/2005 & Verão/2006 & Inverno/2005 & Verão/2006 & Inverno/2005 & Verão/2006 \\
\hline Eudevenopus gracilipes & $19-32$ & $19-32$ & 33,3 & 38,1 & MF & MF \\
\hline Tiburonella viscana & $29-34$ & $29-34$ & 14,3 & 9,5 & $\mathrm{PF}$ & $\mathrm{R}$ \\
\hline Podocerus brasiliensis & $29,1-85$ & $29,1-85$ & 4,8 & 14,3 & MR & PF \\
\hline Parametopella ninis & / & $26-85$ & / & 33,3 & / & MF \\
\hline Tiron biocellata & $28-85$ & $28-85$ & 33,3 & 23,8 & MF & $\mathrm{F}$ \\
\hline Tiron tropakis & $27-85$ & $27-85$ & 14,3 & 23,8 & PF & $\mathrm{F}$ \\
\hline Syrrhoe crenulata & $50-56$ & / & 9,5 & / & $\mathrm{R}$ & / \\
\hline Carangolia sp. & $28,8-96$ & $28,8-96$ & 19 & 19 & PF & PF \\
\hline Urothoe sp.n. & $50-97$ & $50-97$ & 28,6 & 23,8 & $\mathrm{~F}$ & $\mathrm{~F}$ \\
\hline Huerpa sp. & $15-34$ & $15-34$ & 14,3 & 19 & $\mathrm{PF}$ & $\mathrm{PF}$ \\
\hline Paracaprella pusilla & 27 & $26-31$ & 4,8 & 14,3 & MR & $\mathrm{PF}$ \\
\hline Paracaprella tenuis & $34-58$ & $13-55$ & 9,5 & 42,9 & $\mathrm{R}$ & MF \\
\hline
\end{tabular}

\subsubsection{Densidade}

A densidade de anfípodes no inverno foi de 794 ind./0,09 $\mathrm{m}^{2}$, e as famílias Ampeliscidae e Phoxocephalidae foram as dominantes. No verão esse valor subiu para 927 ind./0,09 $\mathrm{m}^{2}$; Phoxocephalidae, Ampeliscidae, Neomegamphopodidae e Amphilochidae foram as famílias dominantes (Figura 10).

No inverno a estação 20 foi o único local que exibiu uma densidade destacadamente superior (132 \pm 10,5 ind./0,09 m²), sendo que Metharpinia sp.n., Urothoe sp.n. e Heterophoxus videns foram as responsáveis pelos valores mais expressivos $(73,27$ e 15 ind./0,09 m², respectivamente). A estação 2 apresentou a segunda maior densidade e as espécies mais representativas foram Metharpinia sp.n. e Ampelisca brevisimulata com valores de densidade de 29 e 24 ind/0,09 m², respectivamente. Seguiu-se a estação 3, com valores muito próximos aos da estação 2 (70 ind./0,09 m²) com dominância das mesmas espécies de cavadores presentes na estação 20 e pertencentes às Famílias Phoxocephalidae e Urothoidae (Heterophoxus videns, Metharpinia sp.n. e Urothoe sp.n.). As estações 5 e 21 foram que apresentaram os menores valores $(9 \pm 0,8$ e $7 \pm 0,5$ ind./0,09 $\mathrm{m}^{2}$, respectivamente) (Figura 10).

No verão destacaram-se três estações, 14, 20 e 2. As estações 14 e 20 apresentaram os maiores valores de densidade, $165 \pm 9,93$ e $128 \pm 8,06$ ind./0,09 m², respectivamente, causados por espécies diferentes. 0 alto valor na estação 14 foi dado pela dominância de Pseudomegamphopus sp.n. (65 ind./0,09 m²) e Resupinus coloni (32 ind./0,09 $\mathrm{m}^{2}$ ), enquanto que a estação 20 por Metharpinia sp.n. (46 ind./0,09 m²) e Urothoe sp.n. (36 ind./0,09 $\mathrm{m}^{2}$ ). A estação 2 apresentou o terceiro maior valor de densidade, $77 \pm 7$ ind./0,09 $\mathrm{m}^{2}$, e as espécies mais representativas foram Metharpinia sp.n. 
e Ampelisca brevisimulata (29 e 24 ind./0,09 m², respectivamente). As estações 12 e 5 apresentaram os menores valores de densidade, $7 \pm 0,5$ e $12 \pm 0,7$ ind./0,09 $\mathrm{m}^{2}$, respectivamente (Figura 10).

\section{Densidade Média}

Inverno /2005

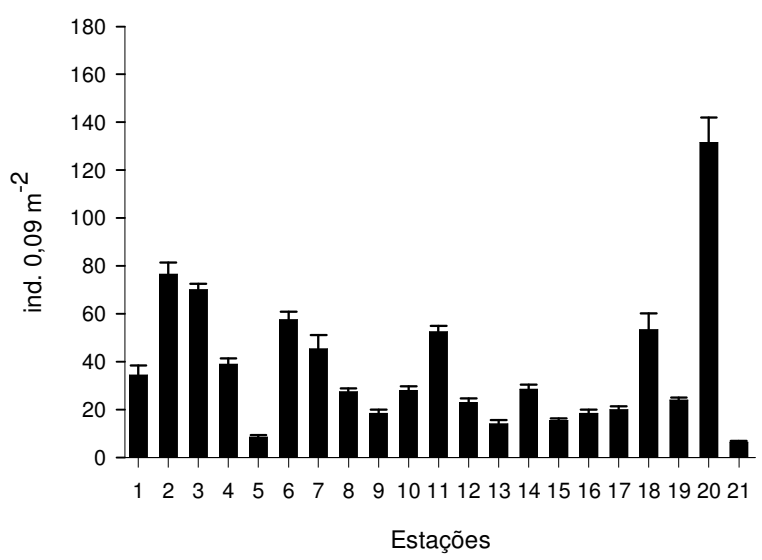

Verão /2006

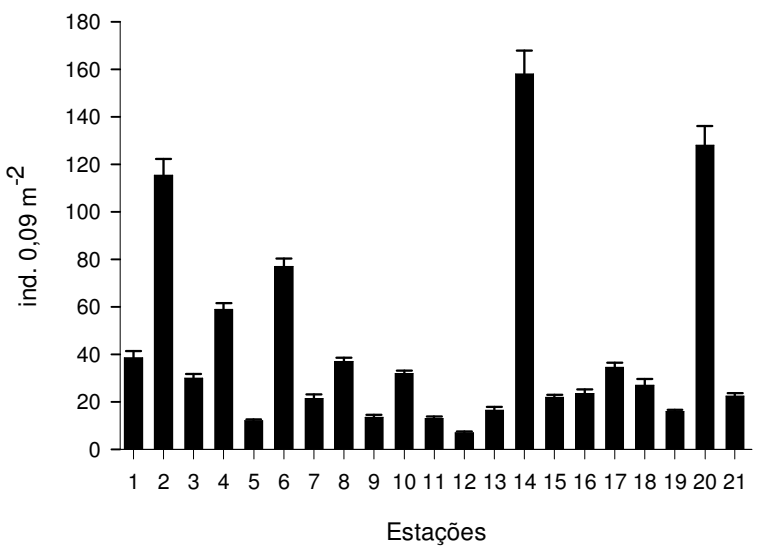

Figura 10 - Densidade média dos anfípodes nas estações amostradas nas duas campanhas da plataforma continental entre São Sebastião e Peruíbe, SP.

A Subordem Gammaridea destacou-se como a mais abundante nas duas campanhas, e foi representada principalmente por Ampelisca paria, Metharpinia sp.n., Microphoxus moaresi, Urothoe sp.n. (inverno) e Gitanopsis sp. (verão). Quanto à Subordem Corophiidea, as mais representativas foram Pseudomegamphopus sp.n., Cheirophotis neotropicalis (inverno) e Photis brevipes (verão) (Figura 11).

No inverno foi registrada uma destacada dominância de Ampelisca paria, seguida por Metharpinia sp.n., Urothoe sp.n. e Microphoxus moaresi, que juntas totalizaram mais da metade dos indivíduos coletados (Figura 11A). No verão houve uma maior repartição do número de indivíduos em relação às espécies, não ocorrendo a dominância apresentada no inverno, sendo as espécies mais abundantes Metharpinia sp.n., Ampelisca paria, Pseudomegamphopus sp.n., Gitanopsis sp., Microphoxus moaresi e Resupinus coloni (Figura 11B). 


\section{Densidade média}

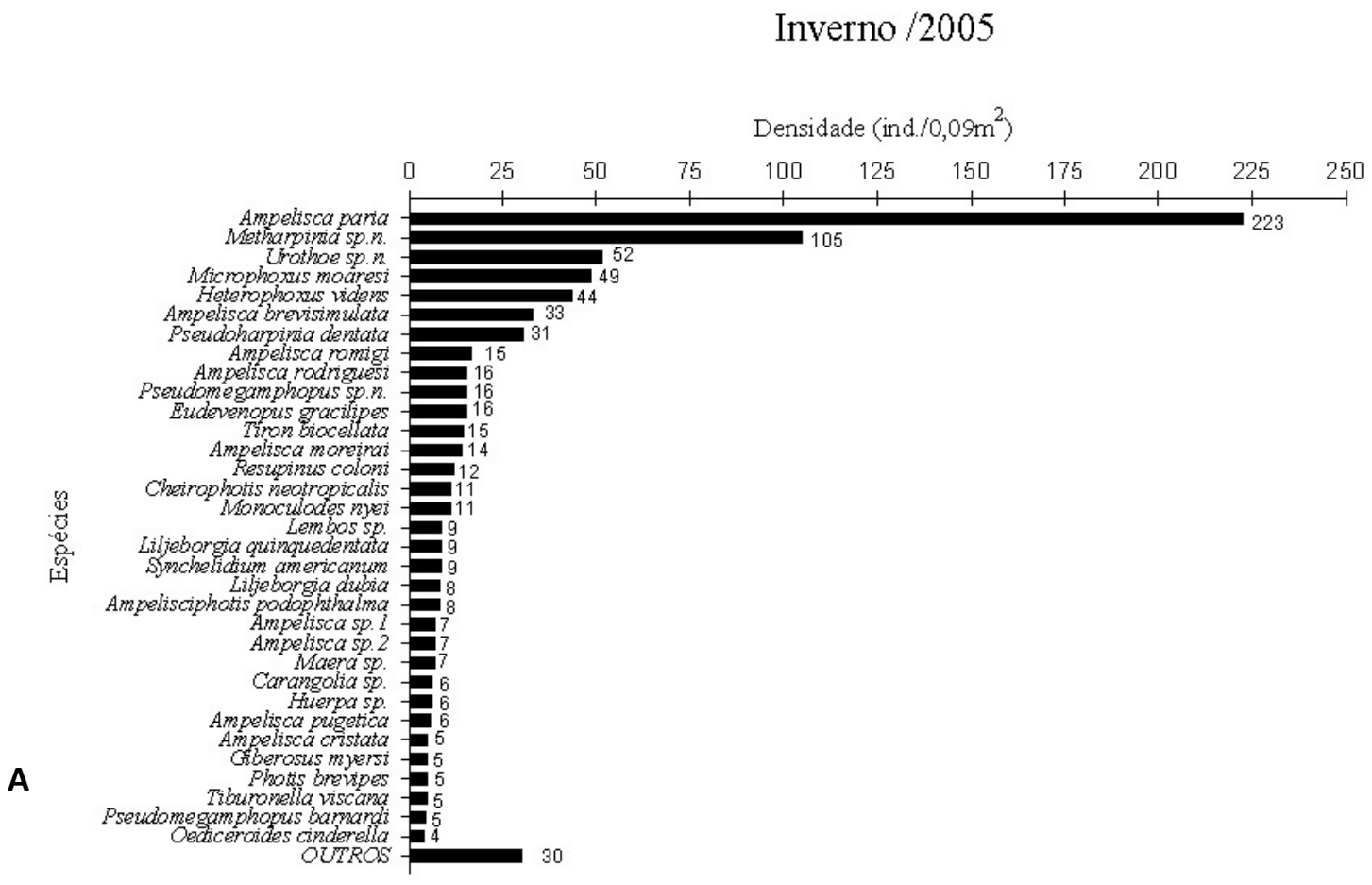

Verão $/ 2006$

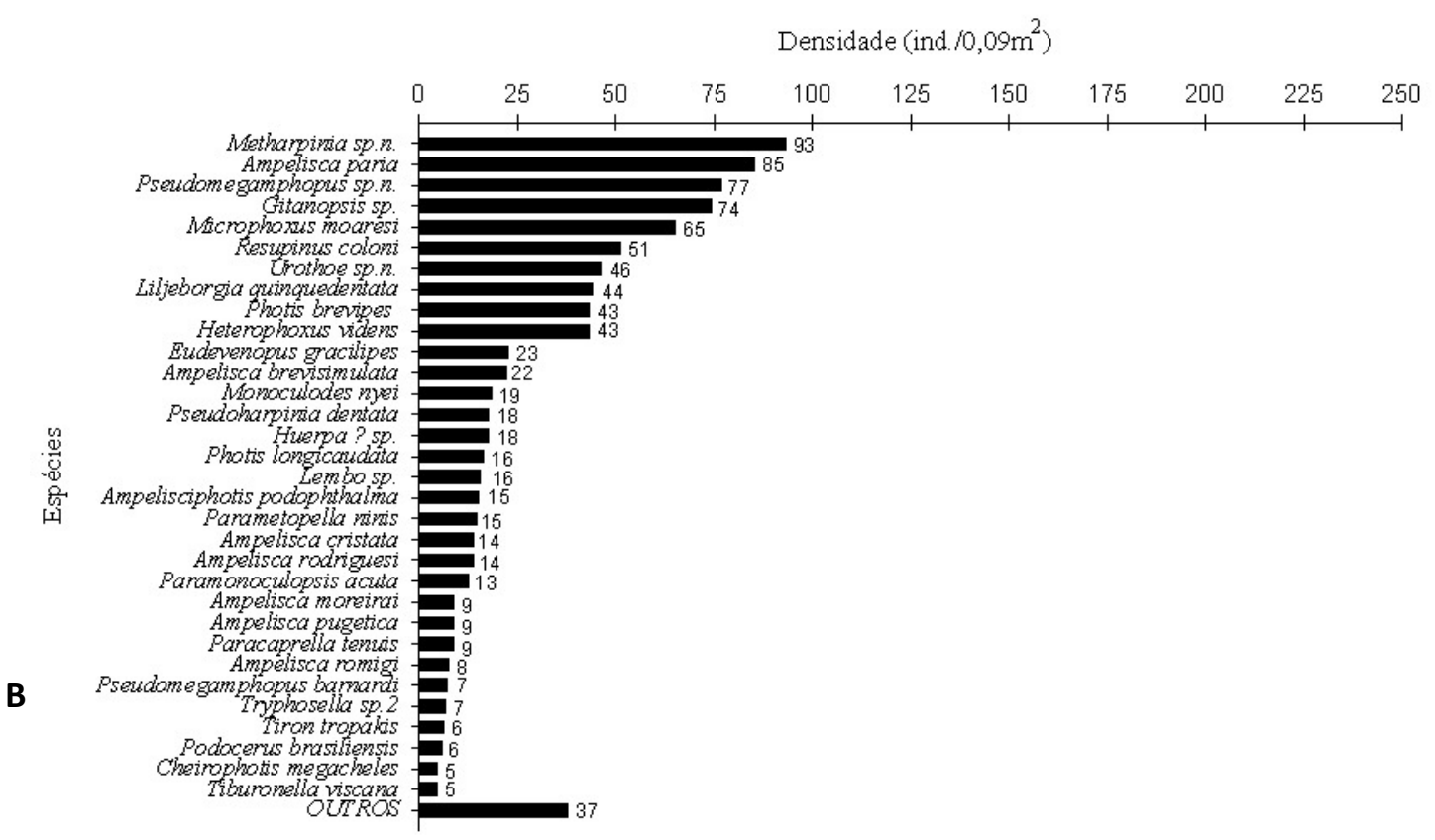

Figura 11 - Densidade média das espécies de anfípodes na plataforma continental entre São Sebastião e Peruíbe, SP. A) Campanha de inverno (agosto e setembro de 2005) e B) Campanha de verão (fevereiro de 2006). 
Ampelisca paria esteve presente somente naquelas estações com profundidades inferiores a $30 \mathrm{~m}$, no presente estudo caracterizadas como zona costeira. Com uma alta densidade no inverno de 223 indivíduos, esta espécie foi mais representativa em apenas duas estações: 18 (50 indivíduos) e 7 (42 indivíduos). As quatro espécies que seguem em densidade são todas cavadoras: Metharpinia sp.n. (105 indivíduos), Urothoe sp.n. (52 indivíduos), Microphoxus moaresi (48 indivíduos) e Heterophoxus videns (44 indivíduos). Com exceção de M. moaresi, que foi obtida na zona costeira e na estação 4, as outras três espécies foram encontradas nos locais mais profundos que $30 \mathrm{~m}$ (estações 3, 4, 11, 12, 20 e 21) e/ou nas duas estações mais ao norte e situadas na isóbata de 30 m (estações 2 e 6). M. moaresi apresentou uma maior densidade na estação 17 (10 indivíduos), enquanto que as demais espécies apresentaram maiores valores na estação 20 (Figura 11A).

Metharpinia sp.n. mostrou sua maior densidade no verão, sendo apenas amostrada nas estações 2 e 20 (47 e 46 ind./0,09 m² em cada). Assim como no inverno, Ampelisca paria foi amostrada nas estações da faixa costeira, com exceção das estações 8, 9, 10 e 15. Sua densidade foi a segunda maior dentre os anfípodes (85 ind./0,09 $\mathrm{m}^{2}$ ) e os maiores valores foram verificados nas estações 1 e 18 (21 e 19 ind./0,09 m², respectivamente). Pseudomegamphopus sp.n. e Gitanopsis sp. também apresentaram alta abundância, sendo a maior observada na estação 14 (65 e 18 ind./0,09 m², respectivamente) e estiveram presentes na maioria das estações da zona costeira (Figura 11B).

Segundo o teste "U" (Mann-Whitney) não houve diferenças estatisticamente significativas para os valores de densidade entre as campanhas, contudo como apresentado acima podemos inferir que houve uma diferença espacial entre as estações (Figura 10 e Tabela 8).

Tabela 8 - Resumo do teste de Mann-Whitney $(\alpha=0,05)$ para densidade, biomassa, riqueza de espécies, diversidade e eqüitatividade obtidas nos períodos amostrados (inverno /2005 e verão/2006) na plataforma continental entre São Sebastião e Peruíbe, SP.

\begin{tabular}{lccccc}
\hline \multicolumn{5}{c}{ TESTE MANN-WHITNEY } \\
\cline { 2 - 6 } & Densidade & Biomassa & S & H $\left(\log _{\mathrm{e}}\right)$ & $\mathrm{J}^{\prime}$ \\
\hline $\mathrm{n} 1$ & 21 & 21 & 21 & 21 & 21 \\
$\mathrm{n} 2$ & 21 & 21 & 21 & 21 & 21 \\
$\mathrm{R} 1$ & 457 & 483 & 414.5 & 385 & 407 \\
$\mathrm{R} 2$ & 446 & 420 & 488.5 & 518 & 496 \\
$\mathrm{U}$ & 215 & 189 & 183.5 & 154 & 176 \\
Z (U) & 0.1384 & 0.7924 & 0.9308 & 16,729 & 11,194 \\
(p) & 0.4450 & 0.2141 & 0.1793 & 0.0472 & 0.1315 \\
Decisão & Aceita $\mathrm{H}_{0}$ & Aceita $\mathrm{H}_{0}$ & Aceita $\mathrm{H}_{0}$ & Rejeita $\mathrm{H}_{0}$ & Aceita $\mathrm{H}_{0}$ \\
\hline
\end{tabular}




\subsubsection{Biomassa}

Na campanha de inverno a biomassa média variou entre 4,15 e 70,7 mg/ 0,09 m², destacam-se as estações 2,3 e 11 com valores mais altos e semelhantes $(70,7 \pm 31,11$ $\mathrm{mg} / 0,09 \mathrm{~m}^{2}, 56,55 \pm 64,8 \mathrm{mg} / 0,09 \mathrm{~m}^{2}$ e 68,25 $\pm 67,95 \mathrm{mg} / 0,09 \mathrm{~m}^{2}$, respectivamente). $\mathrm{Na}$ campanha de verão, os valores variaram entre 3,16 e $48,4 \mathrm{mg} / 0,09 \mathrm{~m}^{2}$ e os valores mais elevados foram verificados novamente nas estações 2 e $3\left(41,4 \pm 34,50 \mathrm{mg} / 0,09 \mathrm{~m}^{2}\right.$ e 48,4 $\pm 55,15 \mathrm{mg} / 0,09 \mathrm{~m}^{2}$, respectivamente) e na estação $20\left(41,1 \pm 7,4 \mathrm{mg} / 0,09 \mathrm{~m}^{2}\right)$. Nas duas campanhas a estação 5 exibiu os menores valores $\left(4,15 \pm 0,778 \mathrm{mg} / 0,09 \mathrm{~m}^{2}\right.$ e 3,16 $\pm 0,219$ $\mathrm{mg} / 0,09 \mathrm{~m}^{2}$ ) (Figura 12).

Ao contrário da densidade, os valores de biomassa apresentaram grande variabilidade entre as amostras de uma estação, especialmente quando foram mais altos, como por exemplo nas estações 2, 3 e 14 em ambas as campanhas, e na estação 11 no inverno. Os desvios padrões das referidas amostras foram elevados, indicando uma grande diferença entre as réplicas. Nos demais locais as réplicas foram mais similares entre si (Figura 12). Apesar de notada essa tendência de diferença entre as estações, pelo teste "U" (Mann-Whitney) não houve diferença significativa para os valores médios de biomassa nas duas campanhas $(22,2 \pm 21,1$ - inverno e 16,16 $\pm 14,5$ - verão) (Tabela 8).

\section{Biomassa}
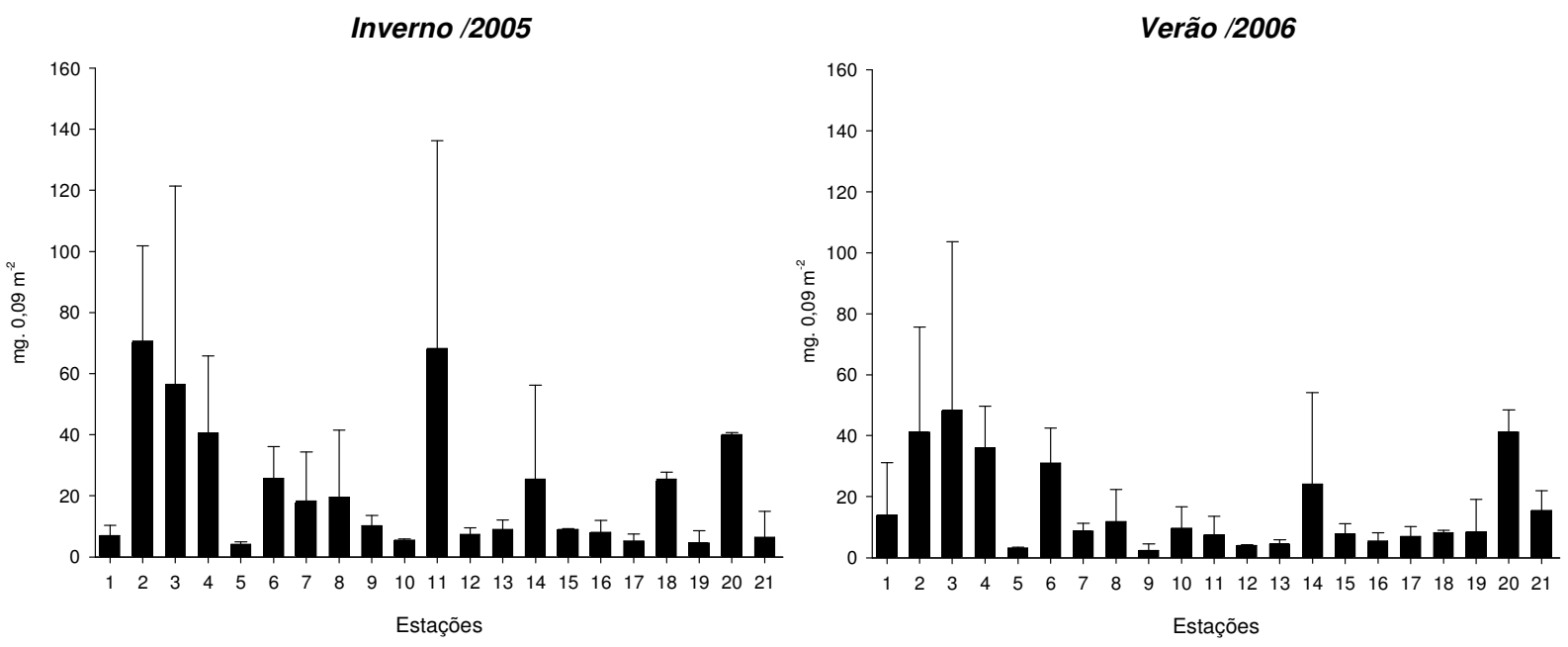

Figura 12 - Biomassa média das estações amostradas nas duas campanhas na plataforma continental entre São Sebastião e Peruíbe, SP. 


\subsubsection{Riqueza de Espécies, Diversidade e Eqüitatividade}

A riqueza de espécies na área variou entre 2 e 25, dependendo do local considerado. De modo geral as estações mais rasas, próximas da linha da costa, apresentaram a menor riqueza em ambas as épocas amostradas (estações 1, 5, 7, 9, 13, 16 e 18). As estações 12 e 21, embora situadas na região mais profunda, próximo da isóbata de $100 \mathrm{~m}$, também apresentaram baixos valores. Por outro lado, as estações situadas ao redor da isóbata de $30 \mathrm{~m}$ apresentaram os maiores valores médios de cada campanha (Tabela 9).

Os valores da diversidade na campanha de inverno variaram de 0,29 e 2,70, os maiores valores de diversidade foram encontrados nas estações $3,6,8,11$ e 19, variando entre 2,70 e 2,21. As estações 1, 7, 13 e 18 apresentaram valores extremamente baixos e os menores da região amostrada $(0,29$ a 0,59$)$. Na campanha de verão os valores da diversidade variaram entre 0,78 e 2,66 e os valores mais elevados foram verificados nas estações 4, 6, 8, 10 e 15, variando entre 2,31 e 2,66, o valor mais baixo foi obtido na estação $18(0,78)$. De um modo geral, a diversidade segue também o mesmo padrão apresentado para a riqueza. As estações ao redor da isóbata de $30 \mathrm{~m}$ apresentaram nas duas campanhas os maiores valores médios e as estações mais rasas apresentaram os valores mais baixos (Tabela 9 e Figura 13).

Quanto à eqüitatividade, no inverno foram encontrados valores inferiores a 0,5, apenas nas estações $1(0,42), 7(0,26), 13(0,37)$ e $18(0,21)$. 0 maior valor ocorreu na estação $21(0,95)$. No verão todas as estações apresentaram valores superiores a 0,5, variando de 0,57, (estação 18), a 0,94 (estação 19). As estações 8, 10, 15 e 19 apresentaram nas duas campanhas os valores superiores a 0,8, indicando haver nesses locais uma distribuição mais homogênea do número de indivíduos entre as espécies. Nesses locais os maiores valores de eqüitatividade corresponderam com valores mais elevados de riqueza e diversidade (Tabela 9 e Figura 13).

Segundo o teste estatístico de Mann-Whitney, os valores de riqueza de espécies e eqüitatividade não apresentaram diferenças significativas entre as duas campanhas (inverno e verão), ou seja, os valores médios entre elas são muito próximos, tanto para riqueza de espécies $(10,4 \pm 6,68$ - inv. e 11,8 \pm 6 - ver.) quanto para a eqüitatividade $(0,68$ $\pm 0,1$ - inv. e 0,7 $\pm 0,1$ - ver.) (Tabela 8). Entretanto, segundo o mesmo teste, os valores médios de diversidade diferiram entre as duas campanhas, apresentando uma diferença significativa $(1,4 \pm 0,7$ - inverno e 1,8 $\pm 0,4$ - verão) (Tabela 8). 
Tabela 9 - Riqueza de espécies (S), diversidade [H'( $\left.\left.\log _{e}\right)\right]$ e eqüitatividade (J') das estações nas duas campanhas (inverno/2005 e verão/2006) na plataforma entre São Sebastião e Peruíbe, SP.

\begin{tabular}{ccccccc}
\hline \multirow{2}{*}{ Estações } & \multicolumn{2}{c}{ Riqueza de Espécies (S) } & \multicolumn{2}{c}{ Diversidade (H') } & \multicolumn{2}{c}{ Eqüitatividade (J') } \\
\cline { 2 - 7 } & Inverno & Verão & Inverno & Verão & Inverno & Verão \\
\hline $\mathbf{1}$ & 4 & 11 & 0,59 & 1,62 & 0,42 & 0,68 \\
$\mathbf{2}$ & 16 & 24 & 1,84 & 2,14 & 0,66 & 0,68 \\
$\mathbf{3}$ & 25 & 13 & 2,70 & 1,85 & 0,84 & 0,72 \\
$\mathbf{4}$ & 16 & 16 & 1,98 & 2,31 & 0,71 & 0,83 \\
$\mathbf{5}$ & 2 & 8 & 0,54 & 1,86 & 0,78 & 0,90 \\
$\mathbf{6}$ & 20 & 17 & 2,22 & 2,34 & 0,74 & 0,83 \\
$\mathbf{7}$ & 4 & 9 & 0,36 & 1,43 & 0,26 & 0,66 \\
$\mathbf{8}$ & 14 & 15 & 2,21 & 2,36 & 0,84 & 0,87 \\
$\mathbf{9}$ & 4 & 5 & 1,06 & 1,23 & 0,76 & 0,77 \\
$\mathbf{1 0}$ & 11 & 19 & 1,93 & 2,66 & 0,8 & 0,90 \\
$\mathbf{1 1}$ & 21 & 10 & 2,41 & 1,83 & 0,79 & 0,80 \\
$\mathbf{1 2}$ & 7 & 4 & 1,44 & 1,25 & 0,74 & 0,90 \\
$\mathbf{1 3}$ & 3 & 6 & 0,4 & 1,26 & 0,37 & 0,71 \\
$\mathbf{1 4}$ & 11 & 19 & 1,66 & 1,97 & 0,69 & 0,67 \\
$\mathbf{1 5}$ & 11 & 13 & 1,95 & 2,35 & 0,81 & 0,92 \\
$\mathbf{1 6}$ & 5 & 8 & 1,22 & 1,52 & 0,76 & 0,73 \\
$\mathbf{1 7}$ & 9 & 11 & 1,67 & 1,91 & 0,76 & 0,80 \\
$\mathbf{1 8}$ & 4 & 4 & 0,29 & 0,78 & 0,21 & 0,57 \\
$\mathbf{1 9}$ & 14 & 9 & 2,26 & 2,06 & 0,85 & 0,94 \\
$\mathbf{2 0}$ & 14 & 21 & 1,43 & 1,93 & 0,54 & 0,64 \\
$\mathbf{2 1}$ & 4 & 8 & 1,32 & 1,89 & 0,95 & 0,91 \\
\hline Média & 10,4 & 11,9 & 1,5 & 1,8 & 0,7 & 0,8 \\
\hline & & & & & & Eqüitatividade $\left(\mathbf{J}^{\prime}\right)$ \\
& Diversidade (H') & & & &
\end{tabular}

Inverno/2005

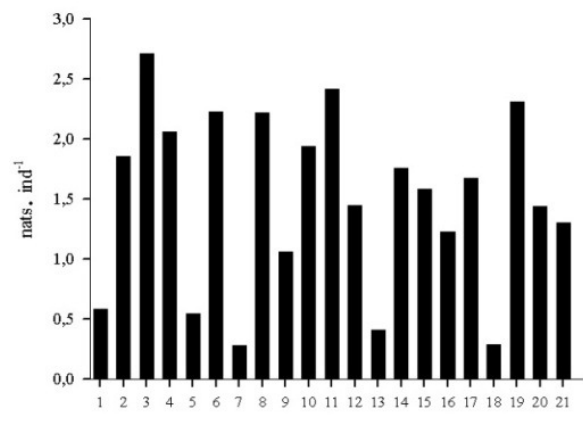

Estações

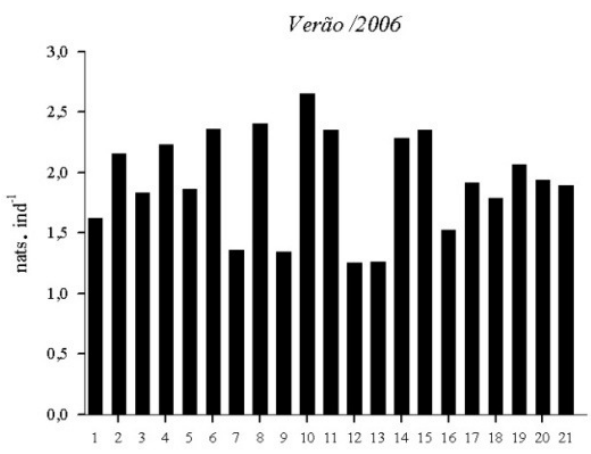

Estações
Inverno /2005

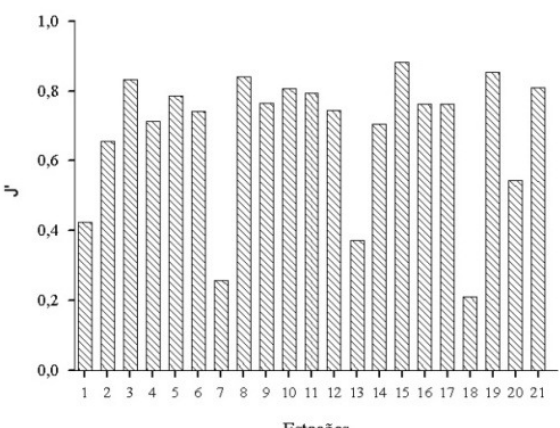

Verão/2006

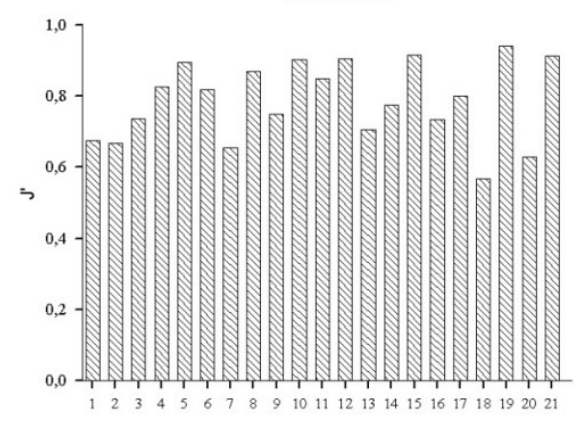

Estações

Figura 13 - Valores da Diversidade de Shannon [H'( $\left.\left(\log _{\mathrm{e}}\right)\right]$ e Eqüitatividade de Pielou (J') para as estações de coleta no inverno /2005 e verão /2006 na plataforma entre São Sebastião e Peruíbe, SP. 


\subsubsection{Distribuição batimétrica e variação sazonal das espécies}

Os limites de distribuição dos anfípodes da área de estudo encontram-se ilustrados nos Anexos X a XII. A partir do levantamento feito por Wabakara et al. (1991) para a costa brasileira, Valério-Berardo(1992) para a plataforma ao largo de Ubatuba - SP, Gallerani (1997), para a região da Bacia de Campos-RJ e Santos (1999) para a plataforma interna da São Sebastião - SP, foi possível verificar que houve a ampliação dos limites de distribuição batimétrica para algumas espécies.

No presente estudo vinte e uma espécies estiveram distribuídas em toda a faixa de profundidade amostrada (10-100m), e dentre elas Heterophoxus videns, Metharpinia cf. iado, Gitanopsis sp., Resupinus coloni e Microphoxus moaresi foram as mais abundantes.

Cinco espécies com tendência estenobática ficaram restritas à faixa de 50 a $100 \mathrm{~m}$, sendo a mais representativa Urothoe sp.n. Oito espécies só foram obtidas da costa até ao redor de $35 \mathrm{~m}$, formando uma fauna costeira característica com dominância de Ampelisca paria. E ainda oito espécies ficaram compreendidas da costa até $50 \mathrm{~m}$, sendo três as predominantes: Metharpinia sp.n., Ampelisca brevisimulata e Photis brevipes.

Uma variação temporal dos diferentes modos de vida foi observada entre as duas campanhas. No inverno ocorreu dominância dos tubícolas de infauna seguida por cavadores, enquanto que no verão ocorreu uma dominância marcante de espécies cavadoras (Figura 14).

Quando se analisa as diferentes zonas batimétricas, nas duas campanhas pode-se notar um padrão de dominância dos diferentes modos de vida com relação à batimetria. Na zona costeira (estações 1, 5, 7, 9, 13, 16e 18), ou região mais interna da plataforma interna, os tubícolas de infauna exibem uma dominância nas duas épocas amostradas, sendo Ampelisca paria a principal representante. A exceção a este fato ocorreu na estação 9 (verão), que não apresentou espécie desse grupo (Figura 14).

Nas duas campanhas a zona intermediária (estações 2, 6, 8, 10, 14, 15, 17 e 19), ao redor da isóbata de 30m, e a zona profunda (estações 3, 4, 11, 12, 20 e 21), situada na plataforma média, exibiram maior diversidade e uma dominância de espécies cavadoras na maioria das estações. Contudo, esta dominância não foi observada para as estações 4, 6 , 14 e 15 no inverno, que apresentaram dominância de tubícolas de infauna e para as estações 4 e 21 no verão, que apresentaram dominância de tubícolas de epifauna (Figura 14). 
Inverno / 2005

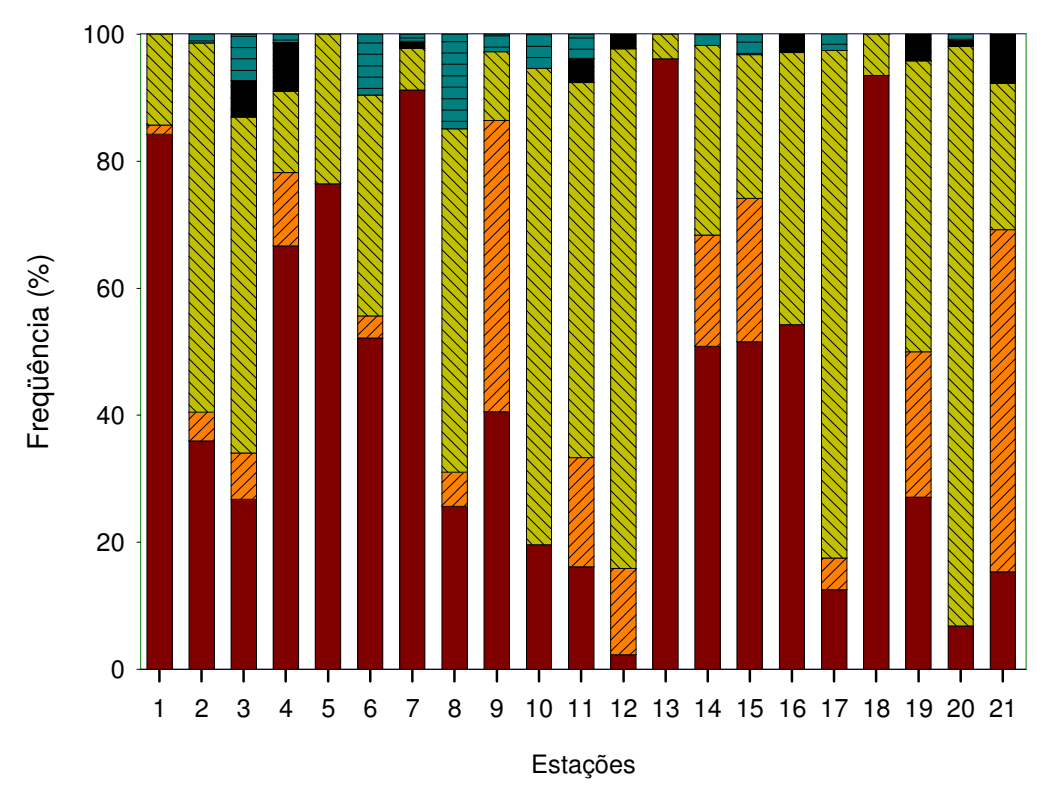

Verão /2006

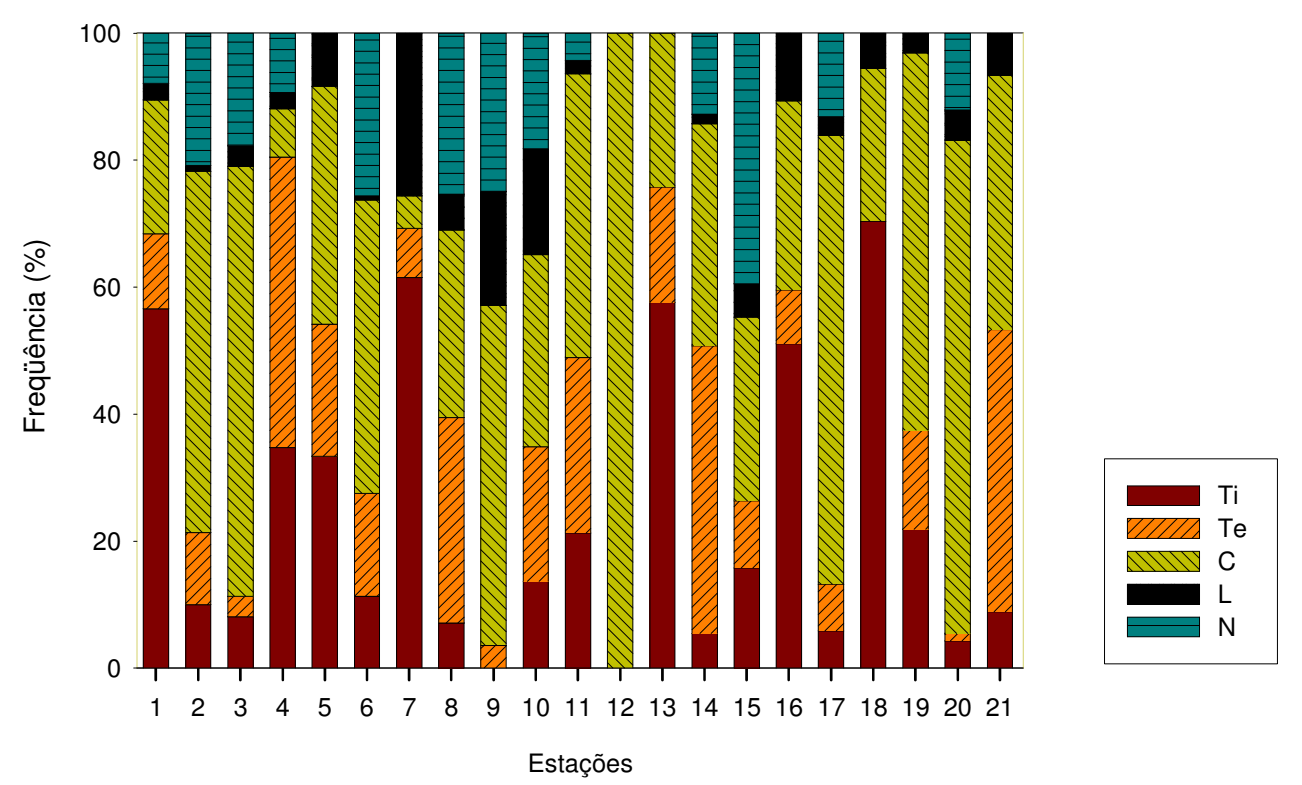

Figura 14 - Densidade Relativa da distribuição dos anfípodes de diferentes modos de vida nas estações amostradas nas duas campanhas inverno /2005 e verão /2006 na plataforma continental entre São Sebastião e Peruíbe, SP. Ti = tubícola de infauna; $\mathrm{Te}=$ tubícola de epifauna; $\mathrm{B}$ = cavador; $\mathrm{L}$ = vida livre; $\mathrm{N}=$ epifauna inquilino 


\subsection{Estrutura das comunidades de Amphipoda}

\subsubsection{INVERNO}

A densidade das espécies de anfípodes em cada estação para ambas as coletas são apresentadas nos Anexos I a VI. Os resultados das análises de agrupamento modo Q e ordenação (n-MDS), com base nas densidades, mostraram inicialmente a separação de dois grandes grupos (Grupo A e B) muito distintos com similaridade de apenas 10\% (Figuras 15 e 16).

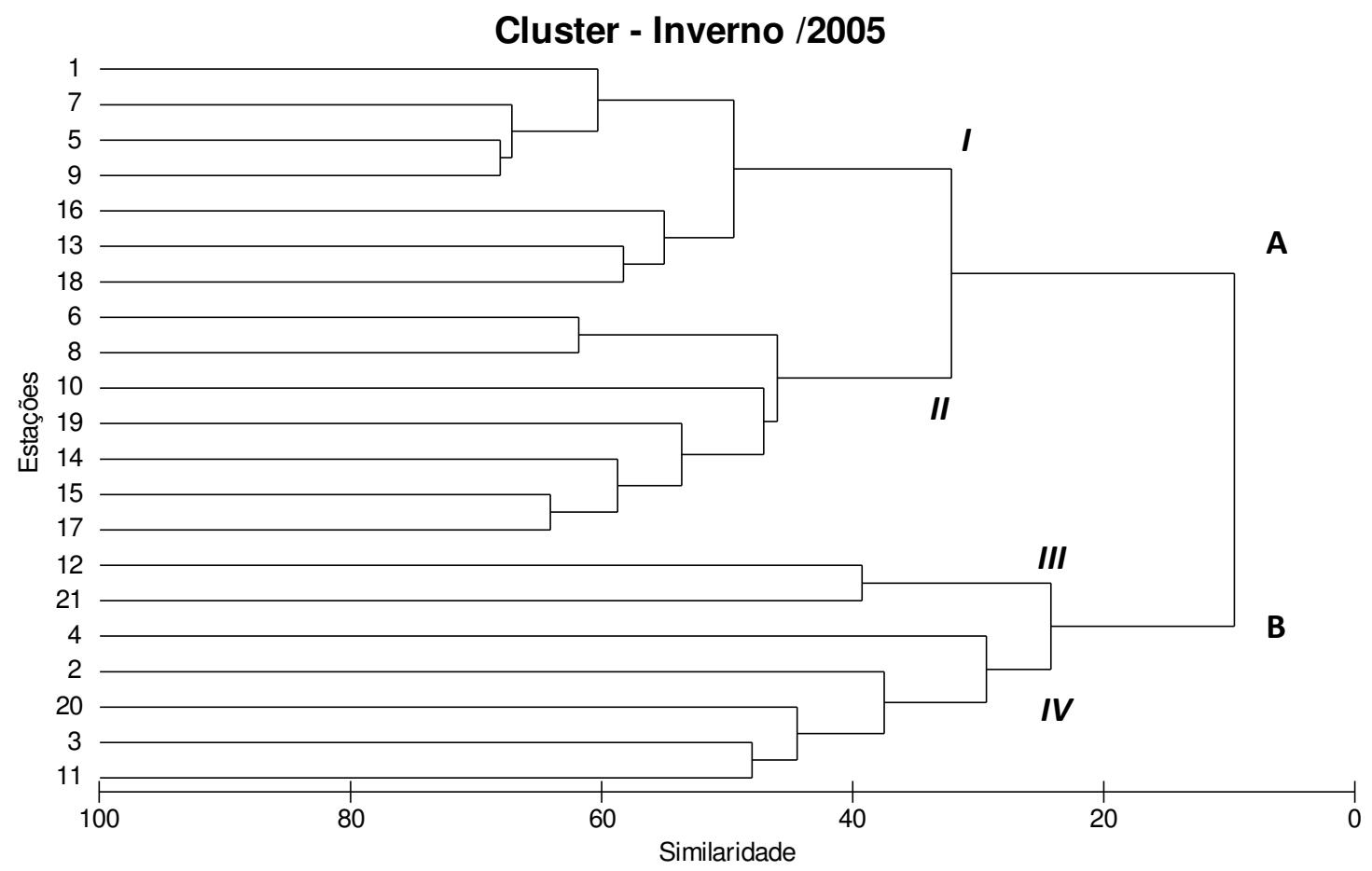

Figura 15 - Análise de Agrupamento em modo Q com para a campanha inverno (agosto de 2005) na plataforma continental entre São Sebastião e Peruíbe, SP.

O primeiro grupo (A) é composto pelas estações amostradas na faixa costeira até a isóbata de $30 \mathrm{~m}$ e o segundo (B) pelas estações amostradas na faixa entre a isóbata de $50 \mathrm{a}$ $100 \mathrm{~m}$. 0 teste de ANOSIM mostrou que estes grupos são estatisticamente diferentes entre si $(\mathrm{R}=0,924 ; \mathrm{p}=0,0001)$.

O grupo A dividiu-se em dois outros grupos, I e II. O Grupo I foi formado pelas estações mais costeiras da plataforma interna (estações 1, 5, 7, 9, 13, 16 e 18); o Grupo II foi representado pelas estações situadas entre 27 a $31 \mathrm{~m}$ de profundidade (estações 6, 8, 10, 14, 15, 17 e 19) (Figuras 15 e 16).

O grupo B também foi dividido em dois grupos distintos (III e IV). 0 Grupo III foi formado por duas estações amostradas próximas à isóbata de 100 m (estações 12 e 21) e o 
Grupo IV foi formado pelas demais estações amostradas entre a isóbata de 50 e $100 \mathrm{~m}$ (estações 3, 4, 11 e 20) mais a estação 2, amostrada na isóbata de 30 m (Figuras 15 e 16). Os resultados do teste ANOSIM (Tabela 10) mostraram que os quatro grupos são diferentes entre si.

n-MDS - Inverno /2005

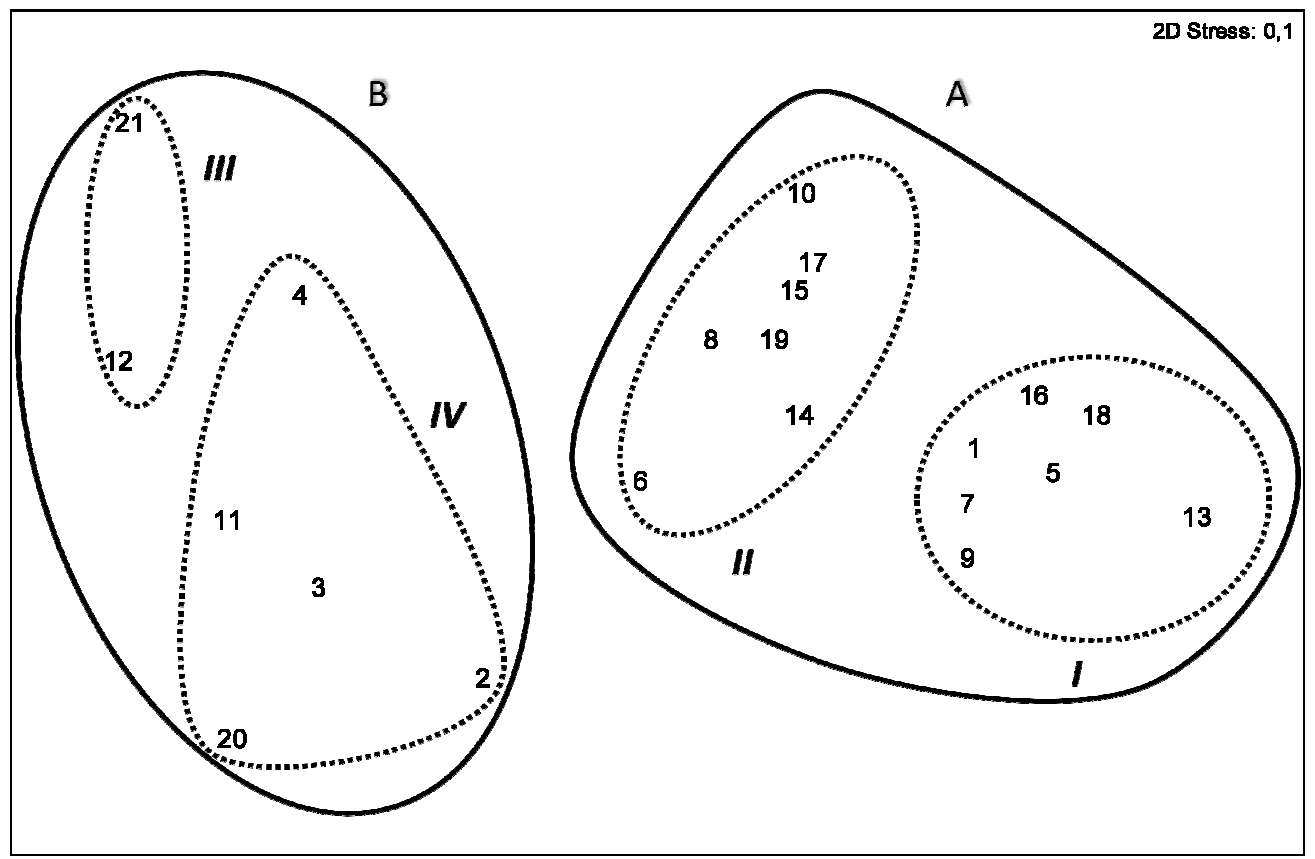

Figura 16- Análise de Ordenação (n-MDS) para campanha de inverno (agosto de 2005) na plataforma continental entre São Sebastião e Peruíbe, SP.

Tabela 10 - Resultados dos testes pareados da Análise de Similaridade (ANOSIM) para os quatro grupos obtidos na Análise de Agrupamento Modo Q. $\left({ }^{*}\right)$ valores significativos $(<5 \%)$.

\begin{tabular}{lcc}
\hline \multicolumn{1}{c}{ Grupos } & R estatístico & $\begin{array}{c}\text { Nível de } \\
\text { significância (\%) }\end{array}$ \\
\hline I, IV & 0,998 & $0,1^{*}$ \\
I, II & 0,897 & $0,1^{*}$ \\
I, III & 1 & $2,8^{*}$ \\
IV, II & 0,939 & $0,1^{*}$ \\
IV, III & 0,673 & $4,8^{*}$ \\
II, III & 1 & $2,8^{*}$ \\
\hline Teste Global: $\mathrm{R}=0,913$ & & \\
\hline
\end{tabular}

Segundo os resultados da análise SIMPER as maiores dissimilaridades foram observadas entre os grupos I e III e grupos I e IV (99,16 e 94,92 \%, respectivamente), evidenciando uma forte diferença na composição e densidade de espécies na zona costeira 
e zonas mais profundas. As dissimilaridades mais baixas foram encontradas entre os grupos mais próximos, ou seja, entre os grupos III e IV e grupos I e II $(75,72$ e 67,78\%).

As espécies que contribuíram para a dissimilaridade entre os grupos foram Ampelisca paria, que apresentou maior abundância no Grupo I e esteve ausente no Grupo III como no Grupo IV; Microphoxus moaresi, Eudevenopus gracilipes e Monoculodes nyei, que apresentaram maior abundância relativa no Grupo II, e alguns estiveram ausentes nos demais grupos; Pseudoharpinia dentata, que apresentou maior abundância relativa no Grupo III e foi ausente no Grupo I e Urothoe sp.n., Heterophoxus videns, Ampelisca brevisimulata, Ampelisca moreirai e Metharpinia sp.n., que apresentaram maior abundância no Grupo IV, e alguns estiveram ausentes nos demais grupos (Tabela 11).

Tabela 11 - Densidade relativa (\%) das espécies de anfípodes nos quatro grupos de estações, da campanha de inverno de acordo com os resultados da análise SIMPER. As espécies que melhor contribuíram para a diferença entre os grupos estão em negrito.

\begin{tabular}{lcc|cc|}
\hline \multirow{2}{*}{\multicolumn{1}{c}{ Espécies }} & \multicolumn{4}{c}{ Abundância relativa (\%) } \\
\cline { 2 - 5 } & \multicolumn{2}{c}{ Grupo A } & \multicolumn{2}{c|}{ Grupo B } \\
\cline { 2 - 5 } Ampelisca paria & Grupo I & Grupo II & Grupo III & Grupo IV \\
Pseudoharpinia dentata & 2,07 & 1,66 & - & - \\
Microphoxus moaresi & - & 0,14 & 1,44 & 0,81 \\
Urothoe sp.n. & 1,00 & 1,39 & - & 0,47 \\
Heterophoxus videns & - & - & 1,02 & 1,39 \\
Metharpinia sp.n. & - & - & 0,5 & 1,62 \\
Eudevenopus gracilipes & - & 0,16 & - & 1,27 \\
Monoculodes nyei & - & 1,18 & - & - \\
Ampelisca brevisimulata & - & 1,08 & - & - \\
Ampelisca moreirai & - & 0,44 & 0,5 & 0,86 \\
Resupinus coloni & - & 0,32 & 0,42 & 0,99 \\
Tiron biocellata & 0,18 & 0,79 & - & 0,17 \\
Photis brevipes & - & 0,74 & - & 0,37 \\
Synchelidium americanum & - & 0,36 & - & 0,61 \\
Ampelisca pugetica & - & 0,14 & - & 0,75 \\
Ampelisca rodriguesi & - & 0,28 & - & 0,77 \\
Cheirophotis neotropicalis & - & - & - & 0,86 \\
Oediceroides cinderella & 0,24 & 0,36 & - & 0,34 \\
Ampelisca sp. 1 & 0,43 & - & - & - \\
Pseudomegamphopus sp.n. & - & - & - & 0,7 \\
Ampelisca cristata & 0,12 & 0,66 & 0,66 & 0,27 \\
\hline \hline & - & 0,4 & 0,5 & 0,57 \\
\hline
\end{tabular}

As principais características de cada grupo (riqueza de espécies, diversidade, eqüitatividade, densidade média, biomassa média, porcentagem média de silte e argila e profundidade média) estão apresentadas na Tabela 12. 
Tabela 12 - Média dos parâmetros biológicos e abióticos dos grupos formados no inverno /2005: Riqueza de espécies (S), Densidade (ind $/ 0.09 \mathrm{~m}^{2}$ ), Diversidade $\left(\mathrm{H}^{\prime}\right)$, Equitatividade (J'), Biomassa (mg./0,09 m²), Silte + Argila (\%)e Profundidade (m).

\begin{tabular}{|c|c|c|c|c|}
\hline & \multicolumn{4}{|c|}{ Inverno / 2005} \\
\hline & Grupo I & Grupo II & Grupo III & Grupo IV \\
\hline $\mathrm{S}$ & 4 & 13 & 6 & 18 \\
\hline $\mathrm{H}^{\prime}$ & 0,64 & 1,98 & 1,38 & 2,07 \\
\hline $\mathrm{J}^{\prime}$ & 0,51 & 0,78 & 0,84 & 0,71 \\
\hline Densidade (ind $/ 0.09 \mathrm{~m}^{2}$ ) & $28 \pm 17,4$ & $29 \pm 13,6$ & $15 \pm 11,3$ & $74 \pm 35,5$ \\
\hline Biomassa (mg/ 0.09m²) & $11,7 \pm 4,7$ & $13,6 \pm 10$ & $7 \pm 1$ & $55 \pm 14,6$ \\
\hline Silte + Argila $(\%)$ & 7,96 & 3,28 & 84,55 & 12,48 \\
\hline Profundidade (m) & 17,6 & 29 & 95 & 56 \\
\hline
\end{tabular}

O grupo I, que apresentou uma profundidade média de 17,6 m destacou-se dos demais por seus baixos valores de riqueza $(\mathrm{S})$, diversidade $\left(\mathrm{H}^{\prime}\right)$ e equitatividade $\left(\mathrm{J}^{\prime}\right)$. As espécies dominantes deste grupo foram Ampelisca paria e Microphoxus moaresi. A espécie Oediceroides cinderella, embora pouco abundante, ocorreu somente nas estações 13, 16 e 18, sendo exclusiva deste grupo (Tabelas 11 e 12).

O grupo II, representado por estações situadas ao redor da isóbata de $30 \mathrm{~m}$, apresentou o menor valor médio de silte e argila entre os grupos. As espécies mais representativas foram Ampelisca paria, Eudevenopus gracilipes, Monoculodes nyei, Resupinus coloni. E as espécies encontradas somente neste grupo foram: M. nyei, E. gracilipes, Metharpinia cf. iado e Paracaprella tenuis. Microphoxus moaresi apresentou aqui sua maior densidade (63 indivíduos).

O grupo III, formado pelas estações 12 e 21, apresentou uma profundidade média de $95 \mathrm{~m}$, e destacou-se dos demais grupos por seu baixo valor de biomassa e por seus altos valores médios de eqüitatividade (J') e de silte e argila (Tabela 12). Assim como apontado pela análise SIMPER, Pseudoharpinia dentata apresentou maior abundância relativa neste grupo seguida por Urothoe sp.n. (Tabela 11).

Quando comparado com os demais grupos, o grupo IV apresentou os maiores valores de riqueza de espécies (S), diversidade $\left(\mathrm{H}^{\prime}\right)$, densidade e biomassa (Tabela 12). Com exceção de Ampelisca paria, neste grupo ocorreu o maior número de espécies do gênero Ampelisca, sendo exclusiva a presença de duas delas no grupo, Ampelisca sp.n. 2 e Ampelisca subtropicalis. As espécies Urothoe sp.n., Heterophoxus videns, Ampelisca brevisimulata, Ampelisca moreirai e Ampelisca pugetica foram as mais abundantes deste grupo. Tryphosella sp. 1 e sp. 2, Prachynella sp., Westwoodilla rectirostris, Ceradocus sp., 
Pardaliscidae cf. Halicoides e Podocerus brasiliensis foram encontradas somente nas estações reunidas neste grupo.

O padrão de distribuição das espécies nas estações de inverno, segundo a análise BIO-Env, estão correlacionados com a batimetria e as frações de areia grossa e argila ( $\rho=$ $0,815 ; \mathrm{p}<0.001)$.

Quando se analisa as variáveis ambientais podemos notar que o Grupo I pode ser caracterizado como aquele que apresenta valores de areia grossa inferiores a 0,10, porém com valor médio de silte e argila maior do que o grupo II $(7,9 \%)$ e com baixa batimetria (média batimétrica 17,6 m). 0 grupo II pode ser caracterizado por uma profundidade intermediária de $29 \mathrm{~m}$, com valores de areia grossa inferiores a 0,90 e com valores nulos de argila para algumas estações. Já o grupo III se diferencia dos demais por exibir valores superiores a $40 \%$ de argila e teores médios de silte e argila treze vezes maior do que o apresentado pelo grupo II e alta profundidade (média batimétrica de $95 \mathrm{~m}$ ) (Tabela 12). Por último o grupo IV se caracteriza por reunir as estações próximas a isóbata de $50 \mathrm{~m}$ com valores de areia grossa inferiores a 1,70.

Como a separação dos grupos foi interpretada em função principalmente das faixas batimétricas, optou-se em realizar também BIO-Env dentro de cada grupo, na tentativa de procurar outros fatores, além da profundidade, que poderiam estar influenciando a distribuição e a composição das espécies dentro de cada grupo. Não foi possível realizar o cálculo para o grupo III porque este foi formado por apenas duas estações.

Diferentes conjuntos de variáveis influenciaram a distribuição das espécies dentro de cada grupo. No grupo I, a melhor correlação obtida foi entre a densidade média da meiofauna, a fração de areia fina e os valores de salinidade $(\rho=0,573 ; \mathrm{p}<0.001)$. Para o grupo II, frações de grânulos, areia muito grossa e argila foram as variáveis influenciadoras $(\rho=0,575 ; p<0.001)$. Um conjunto de variáveis foram correlacionadas para o grupo IV: a fração de areia média e os valores de temperatura e salinidade $(\rho=1 ; p$ $<0.001)$. 


\subsubsection{VERÃO}

Os resultados das análises de agrupamento Modo Q, com base na densidade de anfípodes mostraram a existência de dois grandes grupos de estações com similaridade de 11\% (Figuras 17). A análise de ordenação multidimensional não métrica (n-MDS), mostrou a distribuição relativa das estações no espaço bidimensional e, de modo geral, o resultado coincide com aquele da análise de agrupamento (Figura 18).

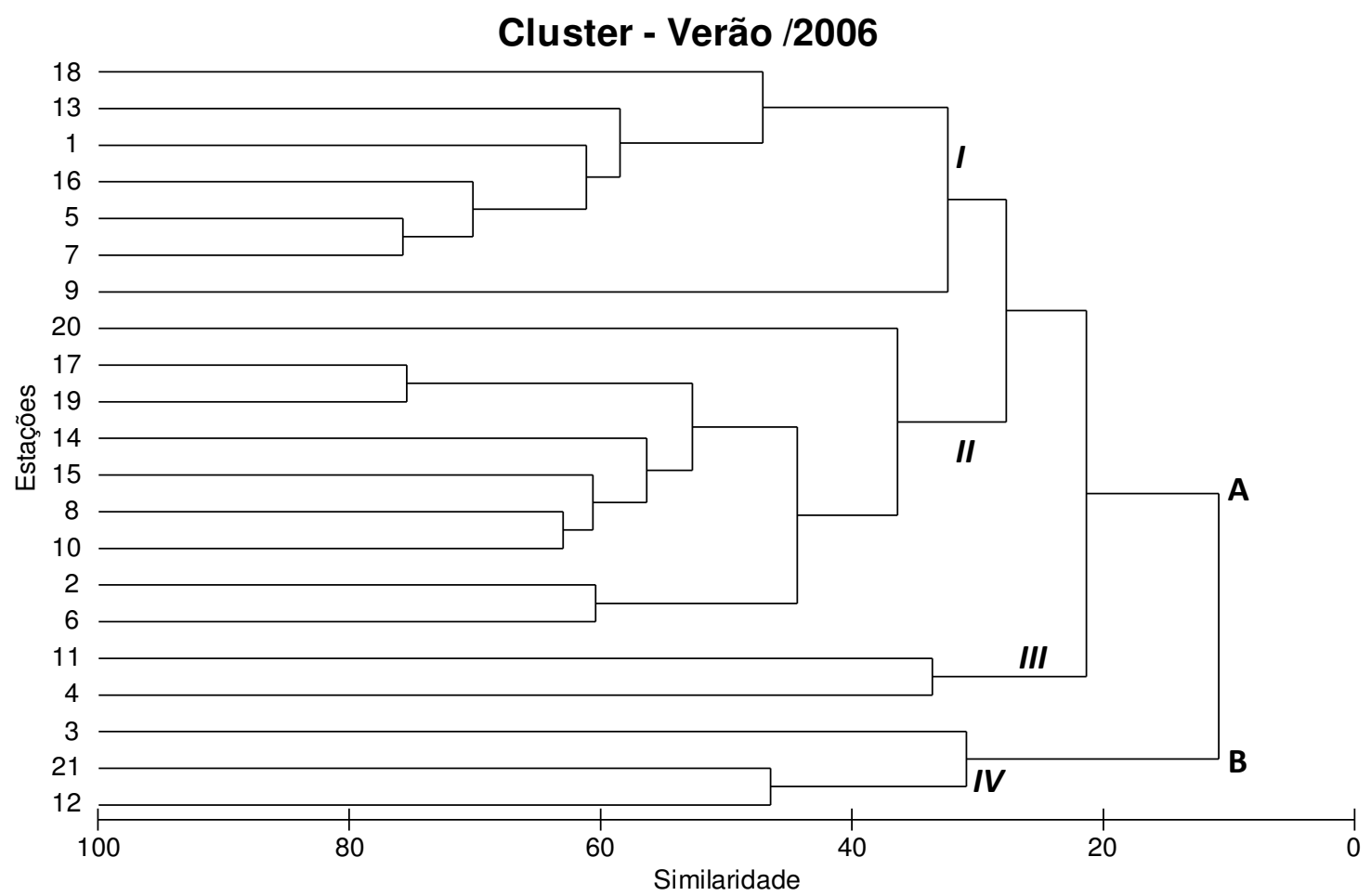

Figura 17 - Análise de Agrupamento em modo Q para a campanha de verão (fevereiro de 2006) na plataforma continental entre São Sebastião e Peruíbe, SP.

O primeiro grupo (A) foi composto pelas estações amostradas na faixa costeira até ao redor da isóbata de $30 \mathrm{~m}$ e por duas estações situadas entre as isóbatas de 50 e $100 \mathrm{~m}$. O segundo grupo (B) foi composto por três estações amostradas entre as isóbatas de 50 e $100 \mathrm{~m}$ de profundidade (Figuras 17 e 18). 0 teste ANOSIM mostrou que estes dois grupos são estatisticamente diferentes $(R=0,814 ; p=0,0002)$.

Dentro do grupo A houve a separação das estações costeiras das duas estações amostradas entre as isóbatas de 50 e 100 m (estações 4 e 11 - Grupo III). Uma segunda divisão ocorreu dentro das estações costeiras do grupo A, resultando na formação de dois novos grupos (Grupos I e II). 
n-MDS - Verão /2006

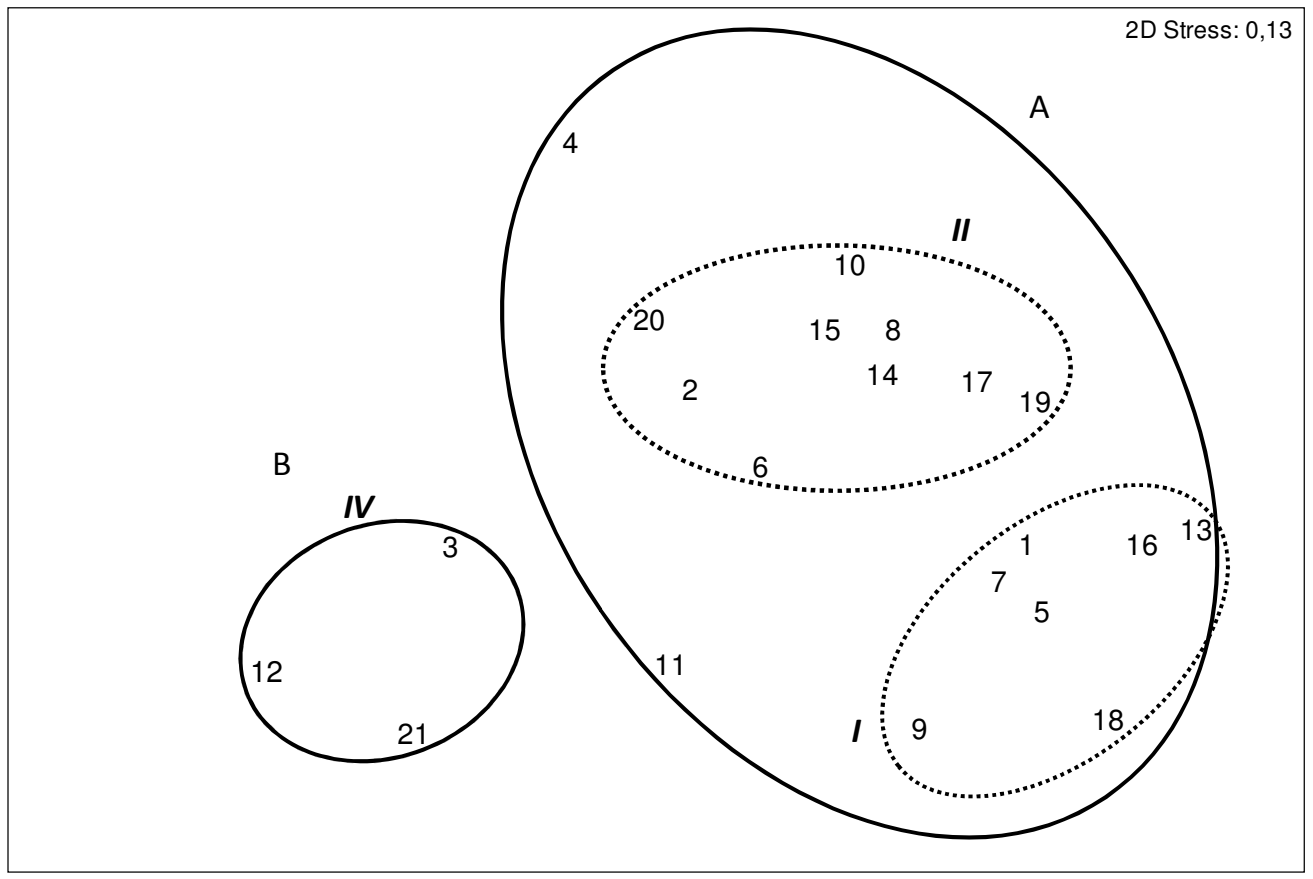

Figura 18 - Análise de Ordenação (n-MDS) para a campanha de verão (fevereiro de 2006) na plataforma continental entre São Sebastião e Peruíbe, SP.

À semelhança do ocorrido no inverno, o Grupo I foi formado pelas estações mais rasas da plataforma interna (estações $1,5,7,9,13,16$ e 18) e o grupo II pelas estações situadas ao redor da isóbata de $30 \mathrm{~m}$ (estações 2, 6, 8, 10, 14, 15, 17, 19 e 20). Os resultados do teste ANOSIM mostraram que três grupos formados dentro do Grupo A são distintos (Tabela 13).

Tabela 13 - Resultados dos testes pareados da Análise de Similaridade (ANOSIM) para os três grupos obtidos dentro do grupo A na Análise de Agrupamento Modo Q. $(*)$ valores significativos $(<5 \%)$.

\begin{tabular}{lcc}
\hline \multicolumn{1}{c}{ Grupos } & R estatístico & $\begin{array}{c}\text { Nível de } \\
\text { significância (\%) }\end{array}$ \\
\hline $\mathrm{I}, \mathrm{II}$ & 0,803 & $0,1^{*}$ \\
$\mathrm{I}, \mathrm{III}$ & 0,903 & $2,8^{*}$ \\
II, III & 0,919 & $1,8^{*}$ \\
\hline \multicolumn{2}{l}{ Teste Global: $\mathrm{R}=0,834$} \\
\hline
\end{tabular}

O grupo B formou um único grupo de estações com similaridade de 31\% (grupo IV) representado pelas estações amostradas entre as isóbatas de 50 e 100 m (estações 3, 12 e 21).

Segundo a análise SIMPER as dissimilaridades médias entre os quatro grupos apresentaram valores maiores que 70, sendo que o maior valor ocorreu entre os grupos I e 
IV (93,70\%). Este resultado foi observado também no inverno, evidenciando novamente uma grande diferença na composição e abundância dos anfípodes da zona mais rasa e da mais profunda. Os demais valores de dissimilaridade entre os grupos foram: Grupos II e IV, 86,42\%; Grupos IV e III, 85,35\%; Grupos I e III, 81,94\%; Grupos II e III, 76,01\% e Grupos I e II, $72,22 \%$.

A dissimilaridade entre os grupos foi ocasionada por Ampelisca paria $e$ Microphoxus moaresi, que apresentaram maior abundância no Grupo I, sendo que A paria esteve ausente nos Grupos III e IV; por Gitanopsis sp., Photis brevipes, Resupinus coloni, Monoculodes nyei e Eudevenopus gracilipes, que apresentaram maior abundância relativa no Grupo II, podendo estar ausentes nos demais; por Ampelisciphotis podophthalma e Urothoe sp.n., que apresentaram elevada abundância no Grupo III e estiveram ausentes nos outros grupos e por Heterophoxus videns, Pseudoharpinia dentata e Carangolia sp. que apresentaram maior abundância no Grupo IV (Tabela 14).

Tabela 14 - Densidade relativa (\%) das espécies de anfípodes nos quatro grupos de estações da campanha de verão de acordo com os resultados da análise SIMPER. As espécies que melhor contribuem para a diferença entre os grupos estão em negrito.

\begin{tabular}{lccccc}
\hline \multirow{4}{*}{\multicolumn{1}{c}{ Espécies }} & \multicolumn{5}{c}{ Abundância relativa (\%) } \\
\cline { 2 - 5 } & \multicolumn{4}{c}{ Grupo A } & Grupo B \\
\cline { 2 - 5 } & Grupo I & Grupo II & Grupo III & Grupo IV \\
\hline Ampelisca paria & 1,59 & 0,51 & - & - \\
Microphoxus moaresi & 1,34 & 1,28 & 0,42 & - \\
Ampelisciphotis podophthalma & - & - & 1,58 & - \\
Heterophoxus videns & - & 0,58 & - & 1,39 \\
Pseudoharpinia dentata & - & 0,09 & - & 1,46 \\
Gitanopsis sp. & - & 1,49 & 0,42 & 0,33 \\
Photis brevipes & - & 1,37 & 0,55 & - \\
Urothoe sp.n. & - & - & 1,34 & 0,65 \\
Resupinus coloni & 0,70 & 1,18 & - & - \\
Liljeborgia quinquedentata & 0,76 & 0,82 & 0,42 & 0,49 \\
Paramonoculopsis acuta & 0,78 & 0,24 & - & - \\
Monoculodes nyei & - & 0,83 & - & - \\
Eudevenopus gracilipes & 0,24 & 0,87 & - & - \\
Carangolia sp. & - & - & - & 0,72 \\
Ampelisca cristata & - & 0,89 & - & - \\
Photis longicaudata & 0,53 & 0,36 & 1,22 & - \\
Tryphosella sp. 2 & - & 0,74 & 0,42 & - \\
Metharpinia sp.n. & - & 0,58 & - & - \\
Ampelisca moreirai & - & 0,47 & 1,02 & - \\
Pseudomegmaphoipus sp.n. & 0,32 & 0,77 & - & 0,46 \\
Paracaprella tenuis & 0,42 & 0,62 & - & 0,28 \\
Parametopella ninis & - & 0,56 & 0,77 & - \\
\hline \hline & & & & \\
\hline
\end{tabular}


As principais características dos grupos (riqueza de espécies, diversidade, eqüitatividade, densidade média, biomassa média, porcentagem média de silte e argila e profundidade média) presentes no verão encontram-se na Tabela 15 .

Tabela 15 - Média dos parâmetros biológicos e abióticos dos grupos formados no verão: Riqueza de espécies (S), Densidade (ind/0.09 $\left.\mathrm{m}^{2}\right)$, Diversidade $\left(\mathrm{H}^{\prime}\right)$, Equitatividade (J'), Biomassa (mg./0,09 $\mathrm{m}^{2}$ ), Silte + Argila (\%) e Profundidade (m).

\begin{tabular}{|c|c|c|c|c|}
\hline & \multicolumn{4}{|c|}{ Verão / 2006} \\
\hline & Grupo I & Grupo II & Grupo III & Grupo IV \\
\hline$S$ & 7 & 16 & 13 & 9 \\
\hline $\mathrm{H}^{\prime}$ & 1,38 & 2,19 & 2,07 & 1,70 \\
\hline$J^{\prime}$ & 0,70 & 0,79 & 0,81 & 0,84 \\
\hline Densidade (ind $/ 0.09 \mathrm{~m}^{2}$ ) & $22 \pm 9,2$ & $69 \pm 53$ & $36 \pm 32,5$ & $20 \pm 11,8$ \\
\hline Biomassa (mg/ 0.09m²) & $7,16 \pm 3,57$ & $20,2 \pm 14$ & $21,8 \pm 20,22$ & $22,6 \pm 23,05$ \\
\hline Silte + Argila (\%) & 11,41 & 4,96 & 48,02 & 69,08 \\
\hline Profundidade $(\mathrm{m})$ & 17,5 & 31,5 & 70,38 & 82,3 \\
\hline
\end{tabular}

Assim como observado no inverno, o grupo I foi o que apresentou os menores valores de riqueza de espécies (S), diversidade $\left(\mathrm{H}^{\prime}\right)$, equitatividade ( $\left.\mathrm{J}^{\prime}\right)$ e biomassa, sendo caracterizado pela menor profundidade média e fundo arenosos (Tabela 15). Dentro das sete espécies que compõem este grupo destacaram-se: Microphoxus moaresi, Ampelisca paria, Paramonoculopsis acuta e Liljeborgia quinquedentata (Tabela 14).

O grupo II com profundidade média de 31,5 m e fundos arenosos destacou-se dos demais grupos por apresentar maior diversidade $\left(\mathrm{H}^{\prime}\right)$, sendo que todas as estações exibiram valores de diversidade superiores a 1,90 (Tabelas 9 e 15). Além disso, este grupo apresentou também os maiores valores de riqueza de espécies (S), densidade e o menor valor médio de silte e argila entre os grupos (Tabela 15). As espécies mais representativas foram: Gitanopsis sp., Photis brevipes, Resupinus coloni, Monoculodes nyei, Eudevenopus gracilipes e Ampelisca cristata (Tabela 14). Além disso, Monoculodes nyei, Ampelisca cristata, Cheirophotis megacheles, Podocerus brasiliensis, Monocorophium acherusicum, Liljeborgia dubia, Listriella titinga, Pardaliscidae cf. Halicoides e Tiburonella viscana foram exclusivas das estações deste grupo.

O Grupo III foi composto por apenas duas estações com profundidade média de 70,4 m, e apresentou altos valores de riqueza de espécies ( $\mathrm{S}$ ), diversidade $\left(\mathrm{H}^{\prime}\right)$, densidade média, biomassa e substrato com boa quantidade de silte e argila (Tabela 15). As espécies mais abundantes foram Ampelisciphotis podophthalma e Urothoe sp.n., sendo a primeira e Oediceroides cinderella exclusivas do grupo (Tabela 14). 
Formado por três estações (3, 12 e 21) situadas entre as isóbatas de 50 e 100 m, o grupo IV exibiu o maior valor médio de silte e argila e a menor densidade média de anfípodes dentre todos os grupos discriminados (Tabela 15). Foi composto por nove espécies, e as que se destacaram em abundância foram: Heterophoxus videns, Pseudoharpinia dentata, Carangolia sp., Urothoe sp.n. e Corophiidae cf. Leptocheirus (Tabela 14)

Considerando-se todos os grupos, a profundidade, temperatura de fundo, porcentagem de $\mathrm{CaCO}_{3}$ e a porcentagem de silte foram o conjunto de variáveis que apresentaram a melhor correlação com o padrão de distribuição e composição das espécies de anfípodes neste Período de coleta $(\rho=0,818 ; \mathrm{p}<0.001)$.

Quando se analisa o conjunto de variáveis ambientais dentro de cada um dos grupos formados pode-se notar que o Grupo I, com profundidade média de 17,5 m, se caracteriza por apresentar altos valores de temperatura de fundo (média do grupo 25,34 ${ }^{\circ}$ C) e baixo valor médio de $\mathrm{CaCO}_{3}$ (média do grupo 3,72). 0 grupo II, com profundidade média de $31,5 \mathrm{~m}$ e temperatura média de fundo de $19,8^{\circ} \mathrm{C}$ pode ser caracterizado pelos baixos valores médios de silte sendo que esse tipo de sedimento esteve ausente na maioria das estações deste grupo. 0 Grupo III, com profundidade média de 70,4 m, apresentou as águas mais frias junto ao fundo, $16,08^{\circ} \mathrm{C}$ e valores intermediários de silte e $\mathrm{CaCO}_{3}$ ( 6,8 e 17,06, respectivamente). 0 último o Grupo IV, com profundidade média de $82,3 \mathrm{~m}$, pode ser caracterizado pelos altos valores de silte e $\mathrm{CaCO}_{3}$ obtidos e, junto com o grupo III, apresentou os valores de temperatura de fundo mais baixos (média do grupo $16,7^{\circ} \mathrm{C}$ ).

Conforme realizado para o inverno, no verão também foi feita a análise BIO-Env dentro dos grupos, exceto para o Grupo IV, por conter apenas duas estações.

No grupo I a correlação que melhor explica a distribuição das espécies foi a combinação das frações de silte e argila, e os valores de temperatura $(\rho=0,868 ; p<$ 0.001). Para o grupo II a combinação de variáveis que melhor explicou foram os valores de carbonato, salinidade e água intersticial presente no sedimento $(\rho=0,762 ; p<0.001)$. Para o grupo IV, a correlação entre os valores de matéria orgânica total e densidade média de meiofauna foi o que melhor explicou a distribuição entre as espécies dentro do grupo ( $\rho$ $=1 ; \mathrm{p}<0.001)$.

As análises globais da distribuição da fauna de anfípodes na plataforma continental interna e média entre São Sebastião e Peruíbe mostraram que houve uma diferença significativa na composição de espécies entre os Grupos I e III (99,16\%) e Grupos I e IV 
(94,92\%) para a campanha de inverno e entre os Grupos I e IV (93,70\%) para a campanha de verão. Esse resultado nos permite inferir que há comunidades características destas duas zonas (costeira e profunda).

Corroborando com este resultado, ao se avaliar os valores inferiores de dissimilaridade existente entre os Grupos I e II nas duas campanhas (67,78\% - inverno e $72,22 \%$ - verão) pôde-se verificar que houve uma similaridade na composição das espécies entre a zona costeira e as estações presentes sobre a isóbata de $30 \mathrm{~m}$ e que nesta faixa pode estar ocorrendo uma transição entre a zona costeira e profunda. 


\subsection{Distribuição vertical das espécies}

Nas duas campanhas a densidade das espécies nos estratos sedimentares apresentou tendência à diminuição do número de indivíduos em função do aumento da profundidade na coluna sedimentar. Desta forma o estrato de superfície mostrou os maiores valores de riqueza de espécies (S), diversidade $\left(\mathrm{H}^{\prime}\right)$ e densidade (Tabela 16 e Figura 19). A maioria das espécies, principalmente aquelas pertencentes às famílias Ampeliscidae e Phoxocephalidae, foram encontradas em todos os estratos de quase todas as estações. No verão, as estações 9 e 13 apresentaram indivíduos apenas nos estratos de superfície (Figura 19).

Para melhor analisar a composição das espécies em relação a sua distribuição vertical, as estações foram agrupadas de acordo com os locais reunidos nas análises de Cluster e n-MDS (mostrados anteriormente). Assim sendo, há o grupo costeiro, formado pelas estações $1,5,7,9,13,16$ e 18; o grupo de estações ao redor da isóbata de $30 \mathrm{~m}$ (estações $2,6,8,10,14,15,17$ e 19) e a faixa de estações situadas entre 50 e $100 \mathrm{~m}$ (estações 3, 4, 11, 12, 20 e 21) (Tabela 16).

Tabela 16 - Valores médios da riqueza de espécies (S), diversidade $\left(\mathrm{H}^{\prime}\right)$ e densidade (ind.0,09 $\mathrm{m}^{-2}$ ) nos diferentes estratos e faixas batimétricas (zona costeira, zona intermediária e zona profunda) nas duas campanhas, agosto de 2005 (inverno) e fevereiro de 2006 (verão) na plataforma continental entre São Sebastião e Peruíbe, SP.

\begin{tabular}{|c|c|c|c|c|c|c|}
\hline & \multicolumn{6}{|c|}{ Zona Costeira (10-24m) } \\
\hline & \multicolumn{2}{|c|}{ Superfície } & \multicolumn{2}{|c|}{ Meio } & \multicolumn{2}{|c|}{ Inferior } \\
\hline & Inverno/05 & Verão/06 & Inverno/05 & Verão/06 & Inverno/05 & Verão/06 \\
\hline $\mathrm{S}$ & 4 & 7 & 2 & 2 & 1 & 1 \\
\hline $\mathrm{H}^{\prime}$ & 0,63 & 1,44 & 0,35 & 0,34 & 0 & 0,17 \\
\hline \multirow[t]{4}{*}{ Densidade } & 25 & 20 & 2,5 & 2 & 1 & 1,5 \\
\hline & \multicolumn{6}{|c|}{ Zona Intermediária (25-35m) } \\
\hline & \multicolumn{2}{|c|}{ Superfície } & \multicolumn{2}{|c|}{ Meio } & \multicolumn{2}{|c|}{ Inferior } \\
\hline & Inverno/05 & Verão/06 & Inverno/05 & Verão/06 & Inverno/05 & Verão/06 \\
\hline $\mathrm{S}$ & 11 & 15 & 5 & 4 & 3 & 2 \\
\hline $\mathrm{H}^{\prime}$ & 1,9 & 2,2 & 1,15 & 0,9 & 0,74 & 0,54 \\
\hline \multirow[t]{4}{*}{ Densidade } & 25 & 57 & 7 & 4 & 5 & 2 \\
\hline & \multicolumn{6}{|c|}{ Zona Profunda (50-100m) } \\
\hline & \multicolumn{2}{|c|}{ Superfície } & \multicolumn{2}{|c|}{ Meio } & \multicolumn{2}{|c|}{ Inferior } \\
\hline & Inverno/05 & Verão/06 & Inverno/05 & Verão/06 & Inverno/05 & Verão/06 \\
\hline$S$ & 13 & 11 & 5 & 3 & 3 & 4 \\
\hline $\mathrm{H}^{\prime}$ & 1,83 & 1,88 & 1 & 1 & 0,8 & 0,53 \\
\hline Densidade & 47 & 38 & 6 & 4 & 3 & 8 \\
\hline
\end{tabular}


Inverno / 2005

Superfície
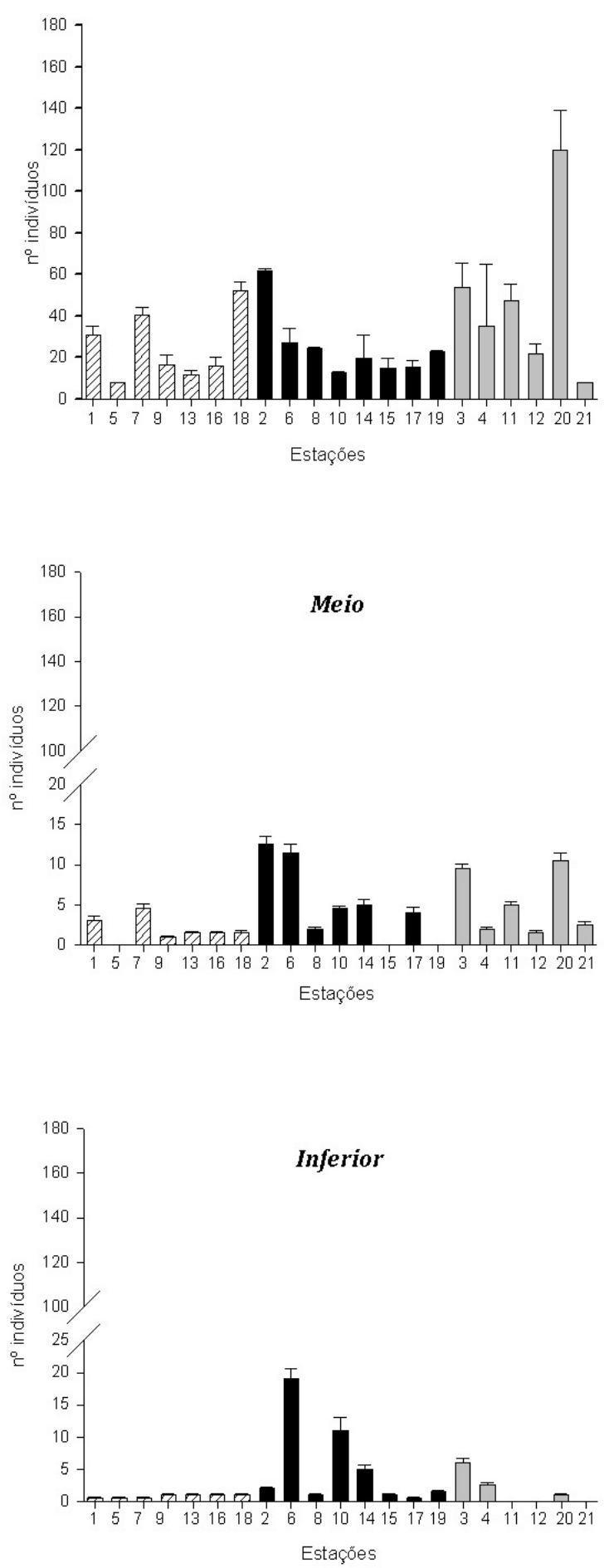

Verão / 2006

Superfície
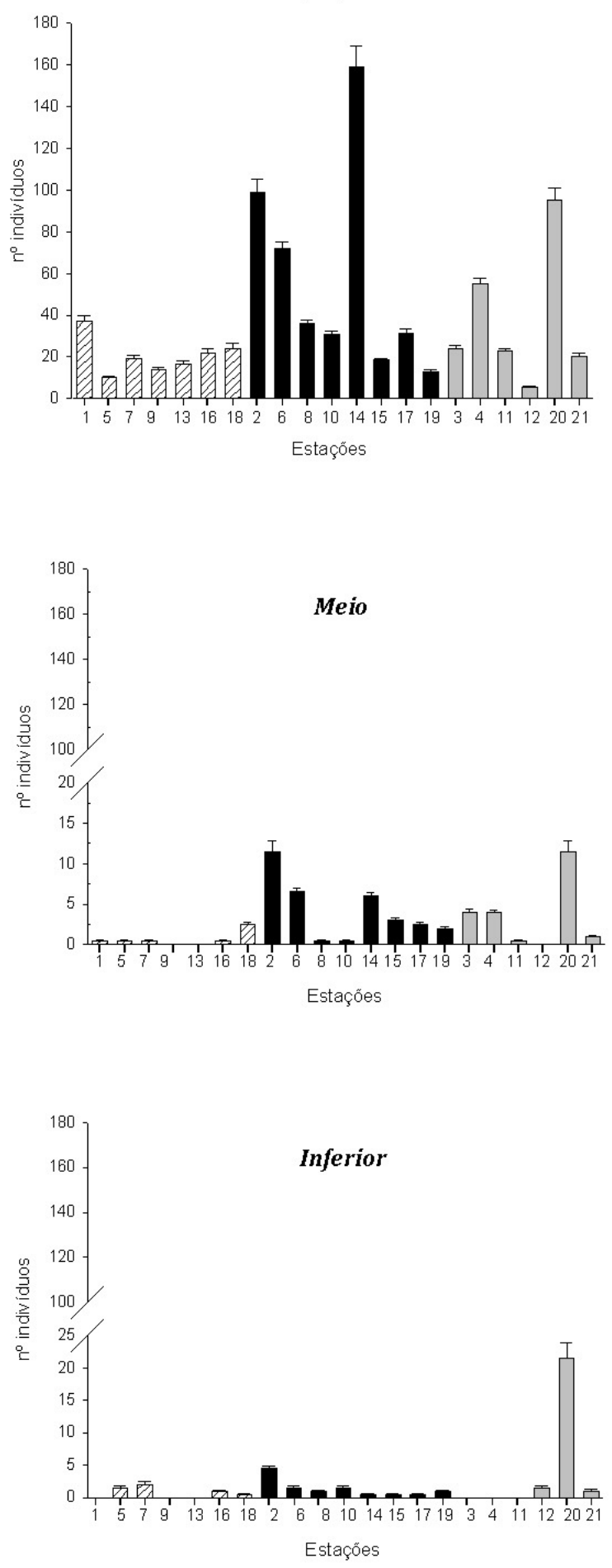

Figura 19 - Densidade de anfípodes obtidos nos estratos de cada uma das estações nas duas campanhas separados em função dos grupos batimétricos, na plataforma continental entre São Sebastião e Peruíbe, SP. 
O estrato de superfície da estação 20 foi o que apresentou a maior densidade na amostragem do inverno (120 $\pm 10,1$ ind/0,09 $\left.\mathrm{m}^{2}\right)$, sendo composto principalmente por espécies cavadoras (Metharpinia sp.n., Urohtoe sp.n. e Heterephoxus videns). Ainda no inverno, para o mesmo estrato, as estações 5 e 21 se destacaram por sua baixa densidade ( $8 \pm 0,86$ e $4 \pm 0,28$ ind./0,09 $\mathrm{m}^{2}$, respectivamente). No verão, em ordem decrescente três estações exibiram alta densidade no estrato de superfície: 14, 2 e 20. A alta densidade da estação $14\left(159 \pm 9,98\right.$ ind/0,09 $\left.\mathrm{m}^{2}\right)$ foi resultado do grande número de Pseudomegamphopus sp.n., enquanto que na estação 2 (99 ind./0,09 $\mathrm{m}^{2}$ ) e na estação 20 (95 ind./0,09 $\mathrm{m}^{2}$ ) a dominância foi de Metharpinia sp.n. No verão, ainda no mesmo estrato, as estações 5 e 12 foram as que apresentaram os menores valores de densidade, com 10 ( \pm $0,65)$ e $5,5( \pm 0,42)$ ind $/ 0,09 \mathrm{~m}^{2}$, respectivamente (Figura 19).

Os anfípodes mostraram-se ausentes nos estratos de meio e inferior de algumas estações nas duas campanhas, sendo a ausência mais freqüente no estrato inferior no período de verão (Figura 19).

Quando se compara a densidade nos estratos de meio e inferior nas duas campanhas, verifica-se que no verão houve um menor número de estações com maiores valores de densidade, principalmente no estrato inferior, onde a maioria das estações exibiu valores menores que dois indivíduos (Figura 19). Destacam-se as estações 6 no inverno e 20 no verão, que apresentam organismos em abundância em toda coluna sedimentar (Figura 19).

Heterophoxus videns, Tiburonella viscana, Podocerus brasiliensis, Pseudomegamphopus sp.n., Pseudomegamphopus barnardi, Ampelisciphotis podophthalma, Listriella titinga, Prachynella sp. e Oediceroides cinderella não foram encontradas nos estratos inferiores nas duas campanhas. Diferentemente do comportamento apresentado pelas demais espécies, Tiron biocellata exibiu no inverno densidade maior no estrato inferior (10,5 indivíduos) e por sua vez, Lembos sp, Cheirophotis neotropicalis, Huerpa sp. Carangolia sp. e Paracaprella pusilla e Paracaprella tenuis, em determinadas estações, foram coletados somente nos estratos inferiores. Ampithoe ramondi foi encontrado somente na estação 19 do inverno, nos estratos de superfície e inferior, enquanto que Parametopella ninis foi obtida somente no verão nos estratos de superfície e meio nas estações 2, 4, 14 e 15. (Figura 20 a 25).

De modo geral, quando se considera a coluna sedimentar das estações que formam a zona costeira observa-se que o estrato de superfície no verão apresentou valores mais altos de diversidade, e no inverno maiores valores de densidade (Tabela 16). Ainda, nas 
duas campanhas, Ampeslica paria foi a espécie mais abundante, principalmente no estrato de superfície do inverno, exceto na estação 9 de verão, onde não foi encontrada (Figuras 20 e 21). Nos outros dois estratos (meio e inferior) os valores de riqueza de espécies e densidade foram baixos sendo no inverno mais frequente $A$. paria e no verão, nos locais que ocorreram anfípodes houve a presença de outras espécies. De modo geral nas estações da zona costeira a densidade e a riqueza de espécies diminuíram uniformemente com o aumento da profundidade da coluna sedimentar (Figuras 20 e 21).

As estações pertencentes à zona intermediária (ao redor da isóbata de $30 \mathrm{~m}$ ) foram as que apresentaram o maior número de espécies em todos os estratos, sendo aí encontrada uma maior diversidade de grupos funcionais e de estratégias alimentares. Além disso, no verão, o estrato de superfície exibiu o maior valor de densidade média obtida para toda a área (Tabela 16 e Figuras 22 e 23).

No estrato de meio, a estação 2 foi a que exibiu a maior densidade para as duas campanhas. Em ambas Metharpinia sp.n. esteve presente, juntamente com Ampelisca brevisimulata no inverno e Liljeborgia quinquedentata no verão. No estrato inferior no inverno a estação 6 apresentou a maior densidade e as espécies mais significativas foram tubícolas infaunais: Ampelisca paria e Ampelisca brevisimulata. No mesmo período e estrato, a estação 10 se destacou pela presença de Tiron biocellata. No verão para o mesmo estrato, a estação 20 mostrou alta densidade de Metharpinia sp.n. (Figura 19).

Para a maioria das estações da zona intermediária, nas duas campanhas, não foi observada a dominância de uma espécie única para todos os estratos como aconteceu na zona costeira. As estações 2, 6 e 10 apresentaram um pico subsuperficial de densidade e riqueza de espécies, com dominância de diferentes espécies por estrato (Tabela 16 e Figuras 22 e 23).

A ausência de $A$. paria e uma maior ocorrência das espécies cavadoras foi observada nas estações mais profundas, ou seja, aquelas que compõem o terceiro grupo. $\mathrm{Na}$ maioria destas estações, nas duas campanhas, não foi observada a presença de indivíduos nos estratos inferiores.

Apenas as estações 3, 4, 11 e 20 no inverno e 20 e 21 no verão apresentaram espécies nos três estratos e na estação 20 ocorreu a maior densidade de Metharpinia sp.n., que dominou o estrato de superfície mas, também esteve presente nos demais estratos. No verão apenas as estações 20 e 21 (Tabela 16 e Figuras 24 e 25). Nenhuma espécie esteve vinculada a um determinado estrato nas duas campanhas. Uma comparação do número de espécies presentes nos três estratos da coluna sedimentar mostra que a estação 4 possui 
pouco mais que o dobro de espécies em relação às estações 12 e 21, todas situadas na faixa mais profunda da amostragem (85, 93 e 97 m, respectivamente) (Figuras 24 e 25). 


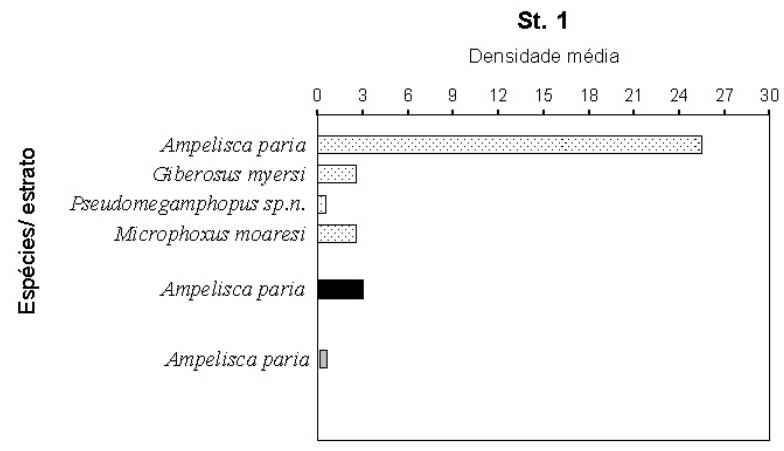

St. 9

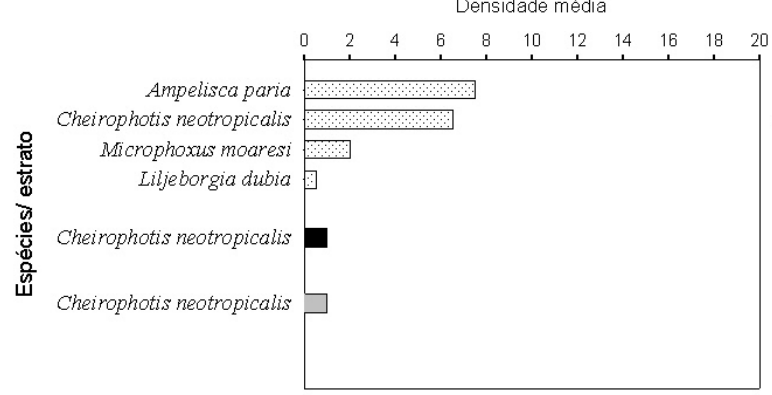

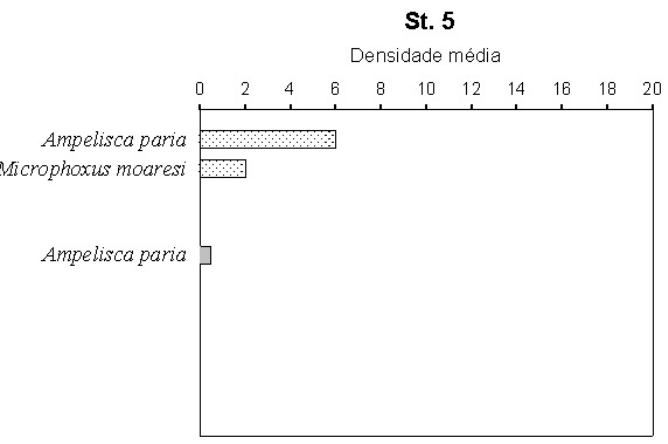

St. 13

Densidade média

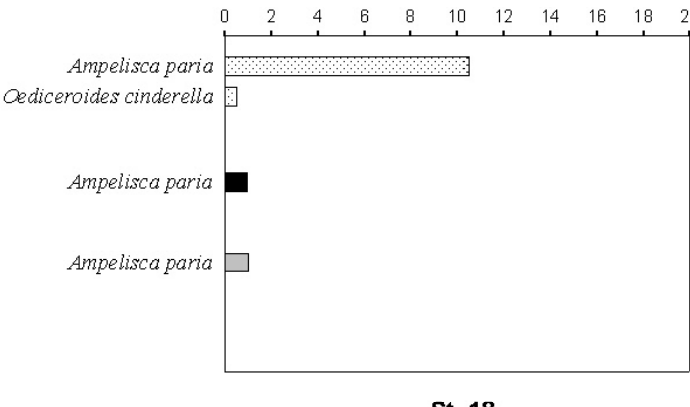

St. 18

Densidade média

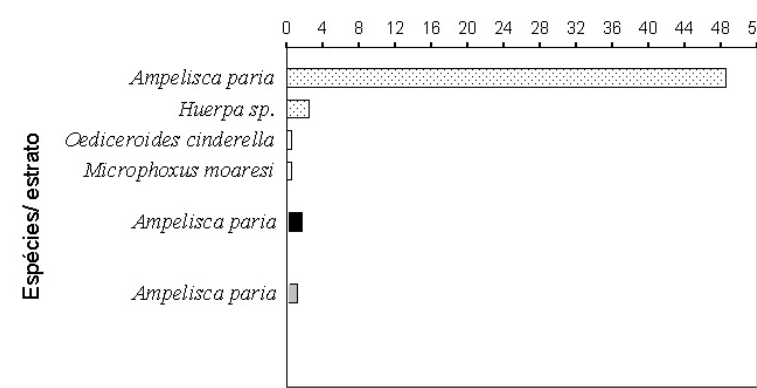

St. 7

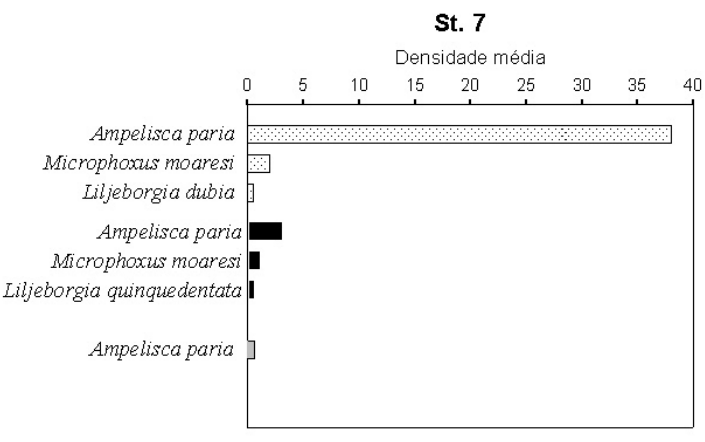

St. 16
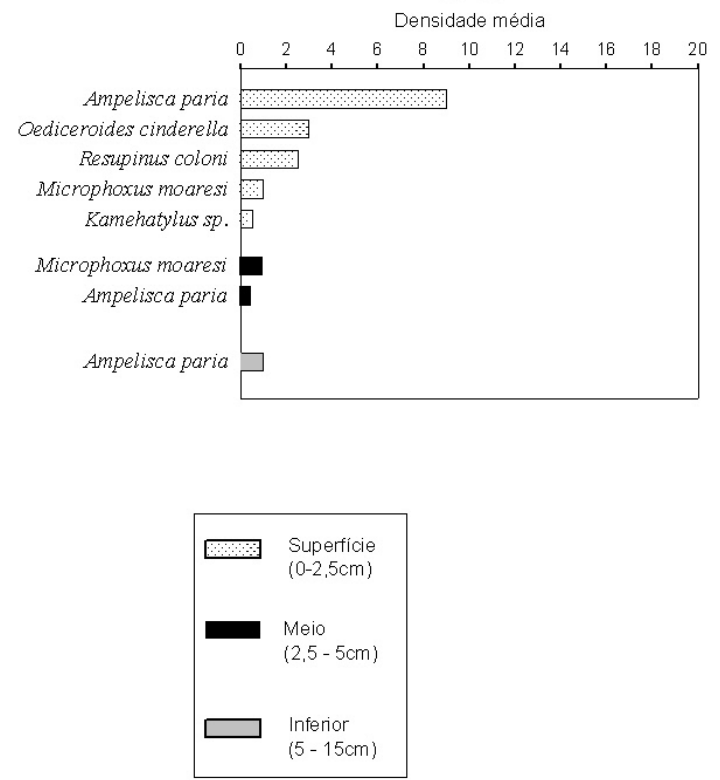

Figura 20- Distribuição vertical em três estratos das espécies de anfípodes nas estações de inverno /2005 amostradas na zona costeira na plataforma continental entre São Sebastião e Peruíbe, SP. 
St. 1

Densidade média

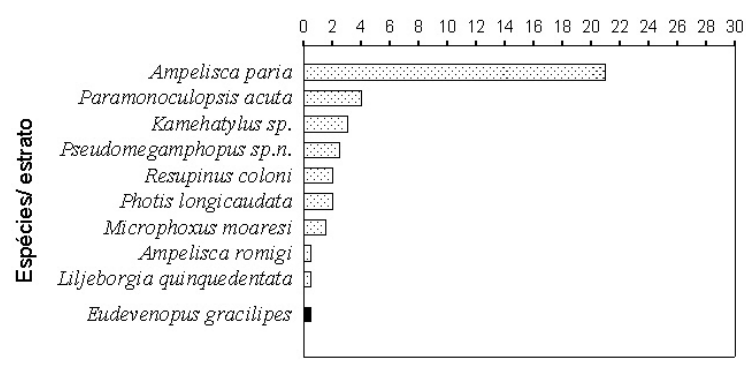

St. 9

Densidade média
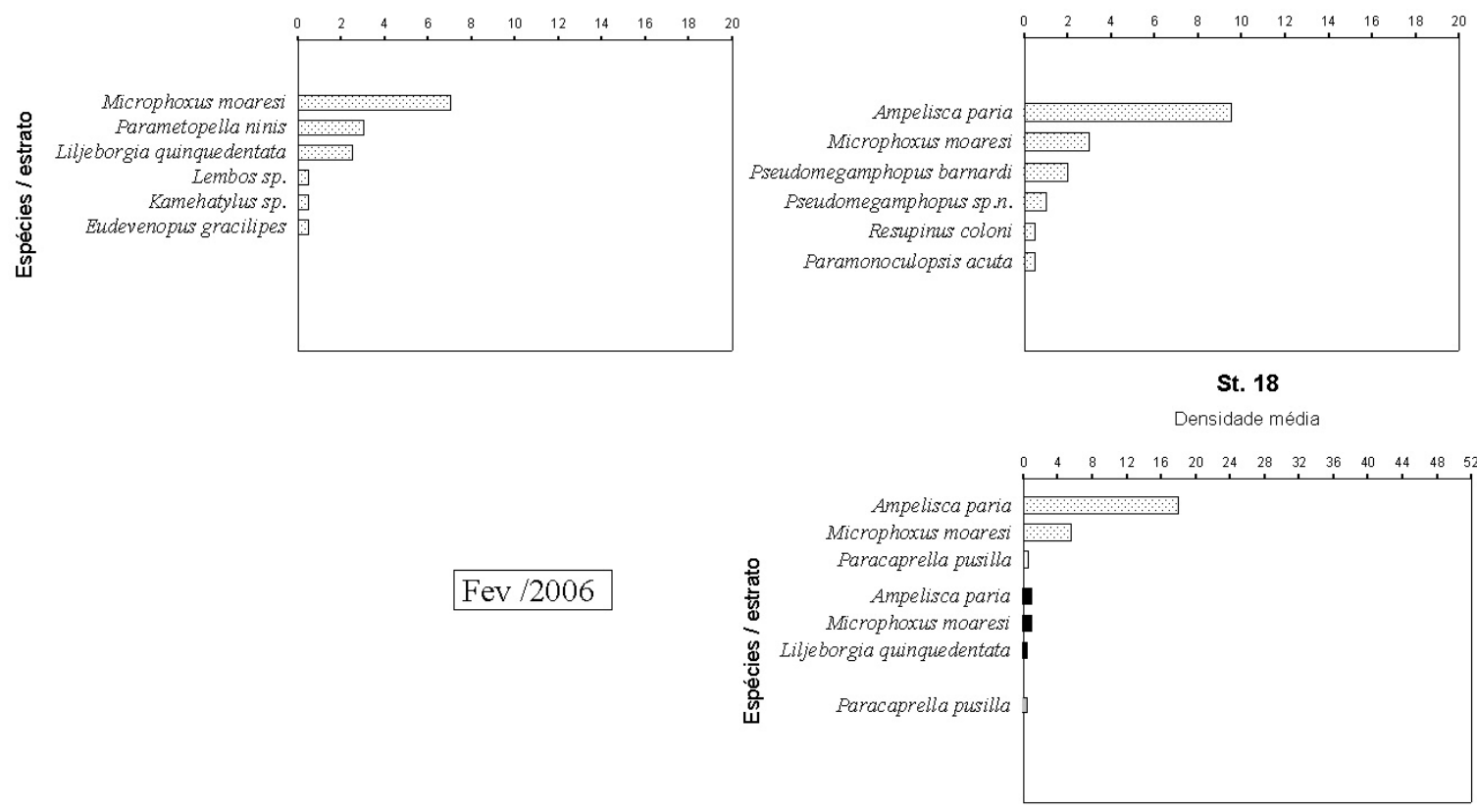

St. 5

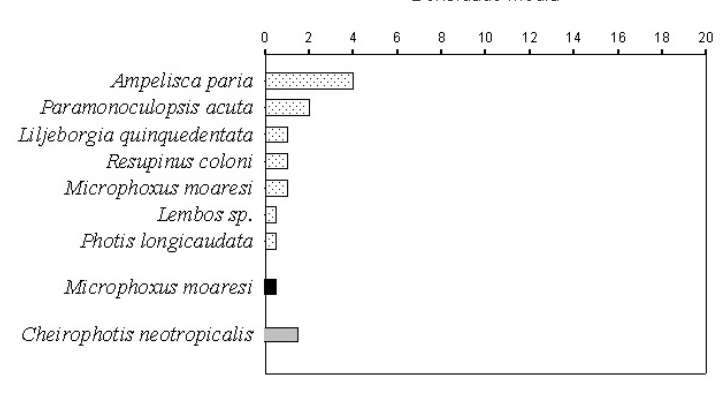

St. 13

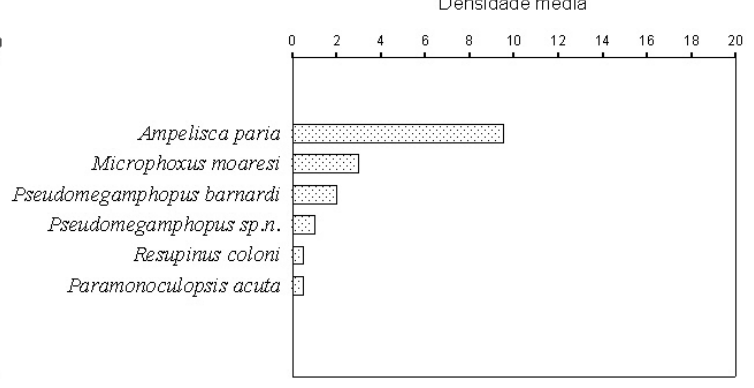

St. 18

St. 18
Densidade médi

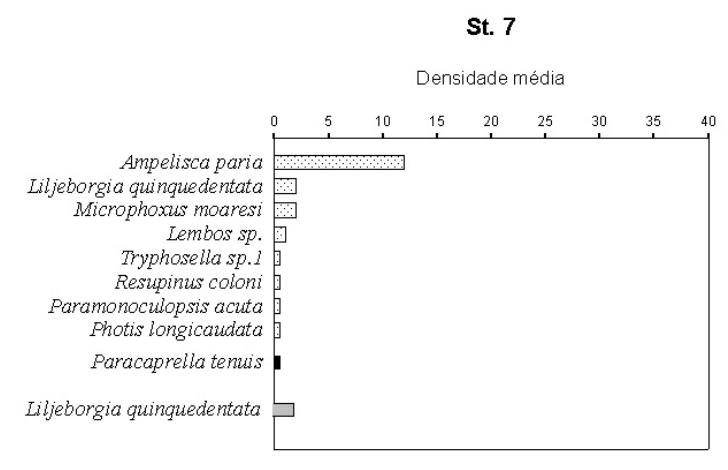

St. 16

Densidade média

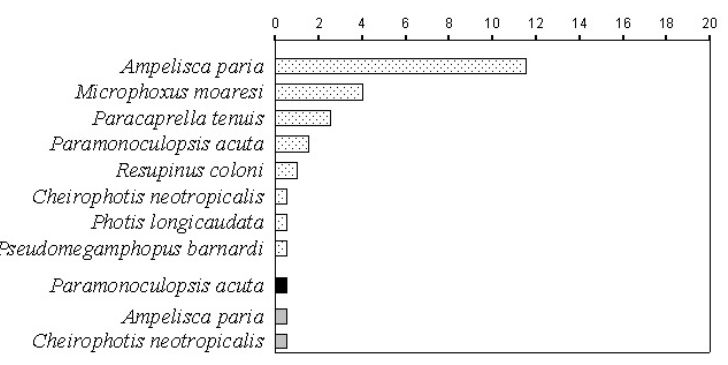

Ampelisca paria
Cheirophotis neotropicalis

continental entre São Sebastião e Peruíbe, SP. 

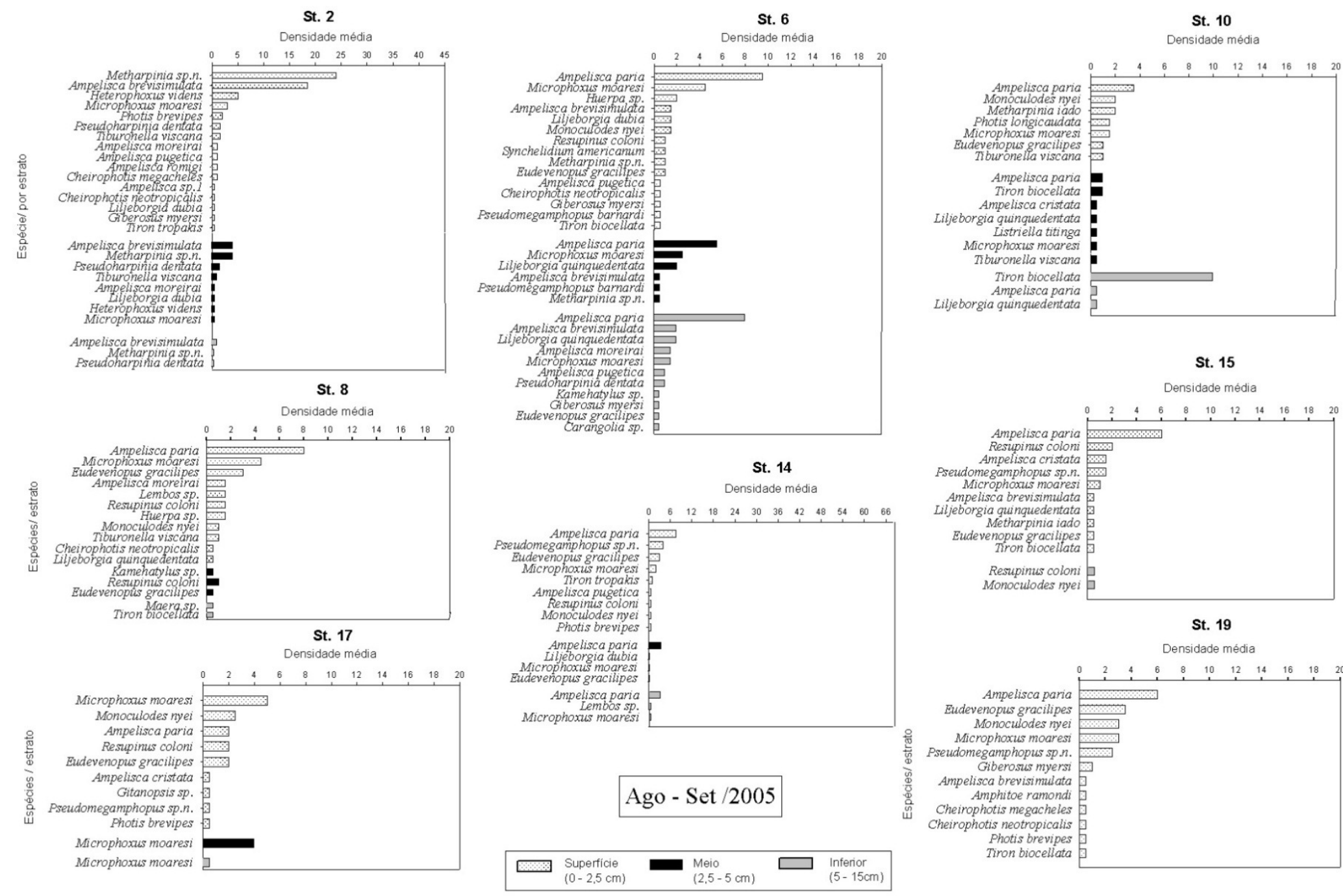

St. 15

Densidade média

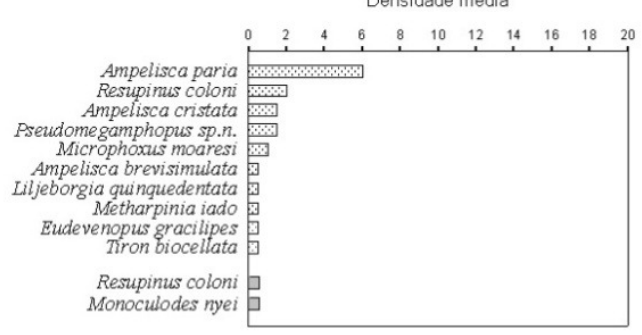

St. 19

Densidade média

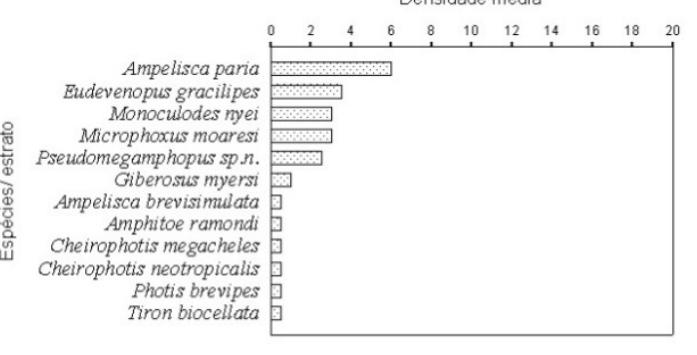

Figura 22 - Distribuição vertical em três estratos das espécies de anfípodes nas estações de inverno /2005 amostradas ao redor da isóbata de 30 m na plataforma continental entre São Sebastião e Peruíbe, SP. 

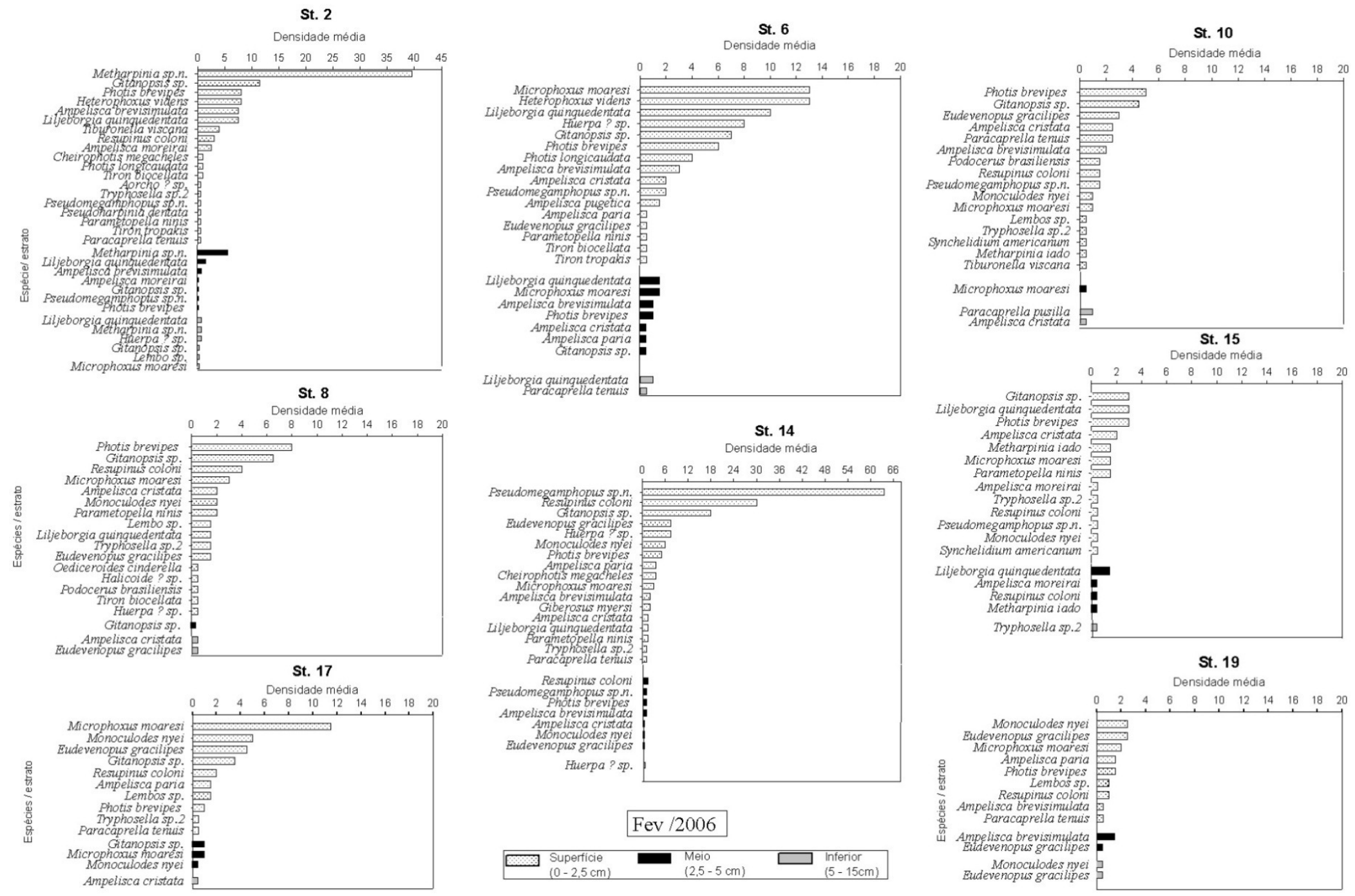

Figura 23 - Distribuição vertical em três estratos das espécies de anfípodes nas estações de verão /2006 amostradas ao redor da isóbata de $30 \mathrm{~m}$ na plataforma continental entre São Sebastião e Peruíbe, SP. 
St. 3

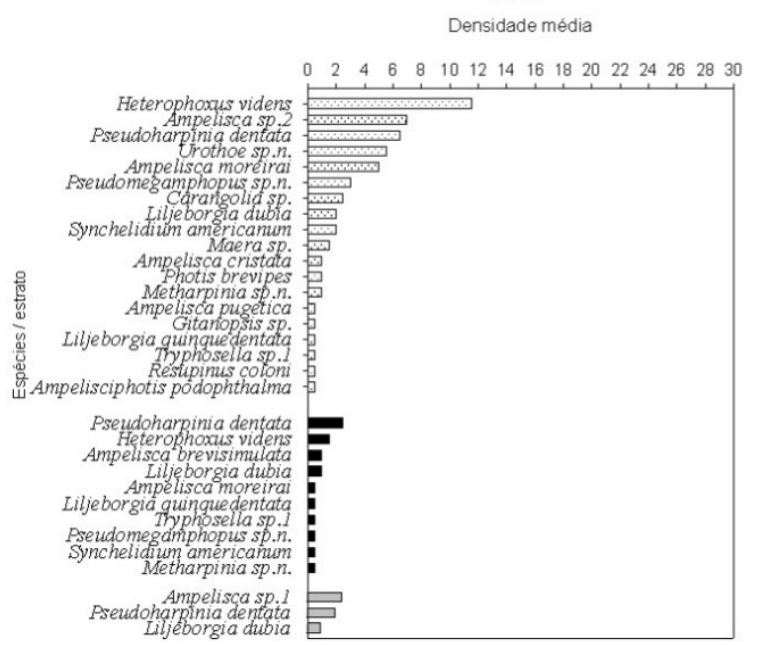

St.12

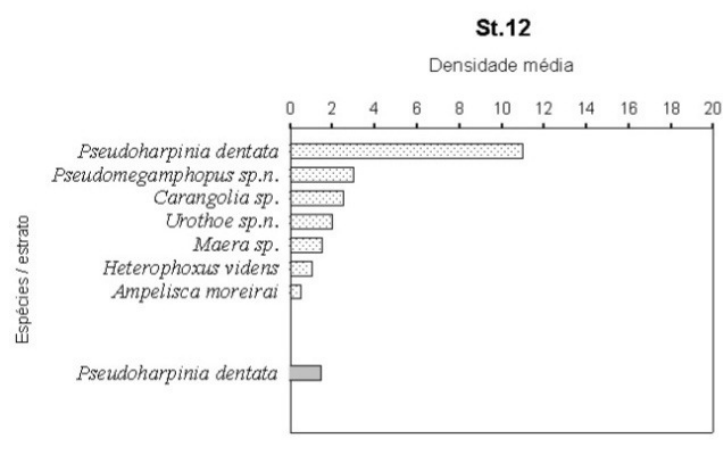

Ago - Set $/ 2005$
St. 4

Densidade média

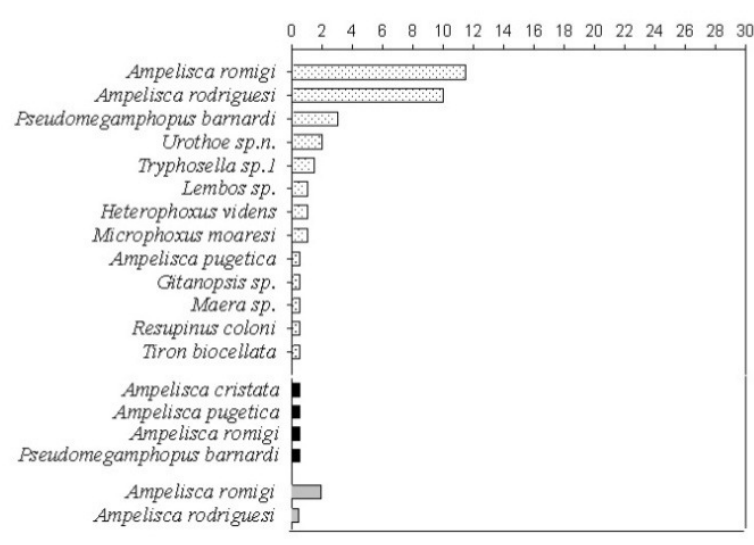

St. 20

Densidade média

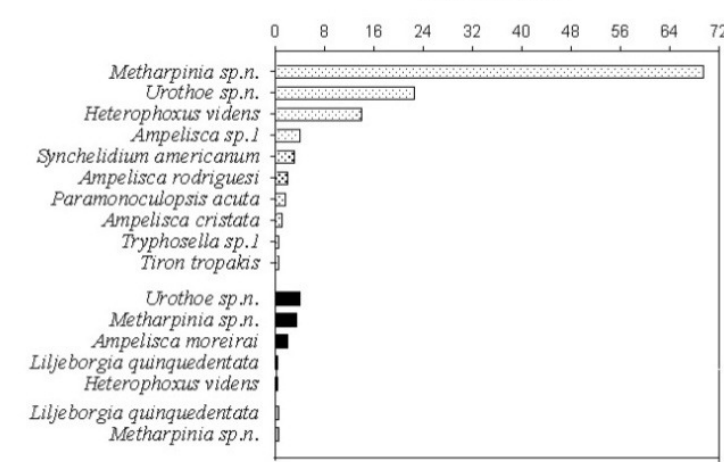

St. 11

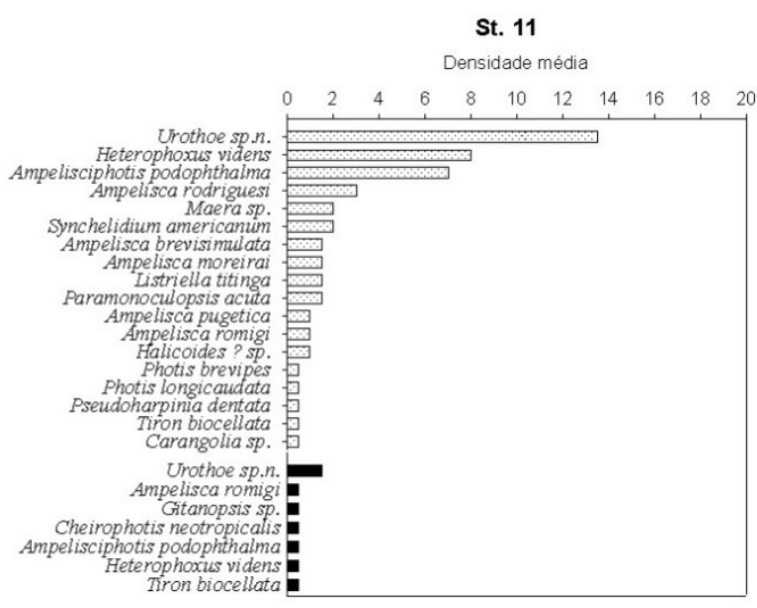

St. 21

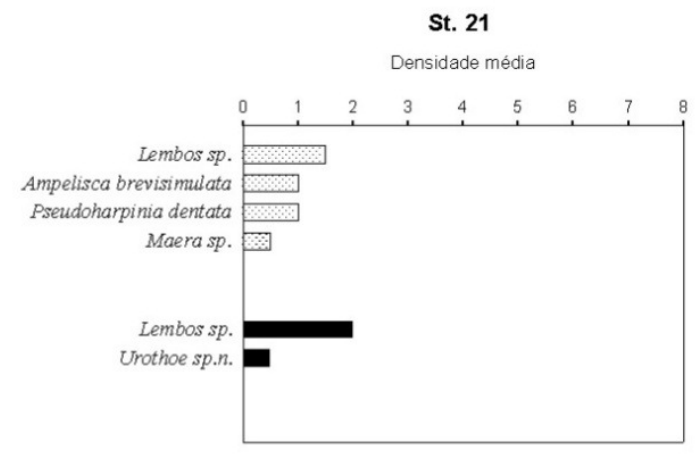

Figura 24 - Distribuição vertical em três estratos das espécies de anfípodes nas estações de inverno /2005 amostradas entre as isóbatas de 50 e 100 m na plataforma continental entre São Sebastião e Peruíbe, SP. 


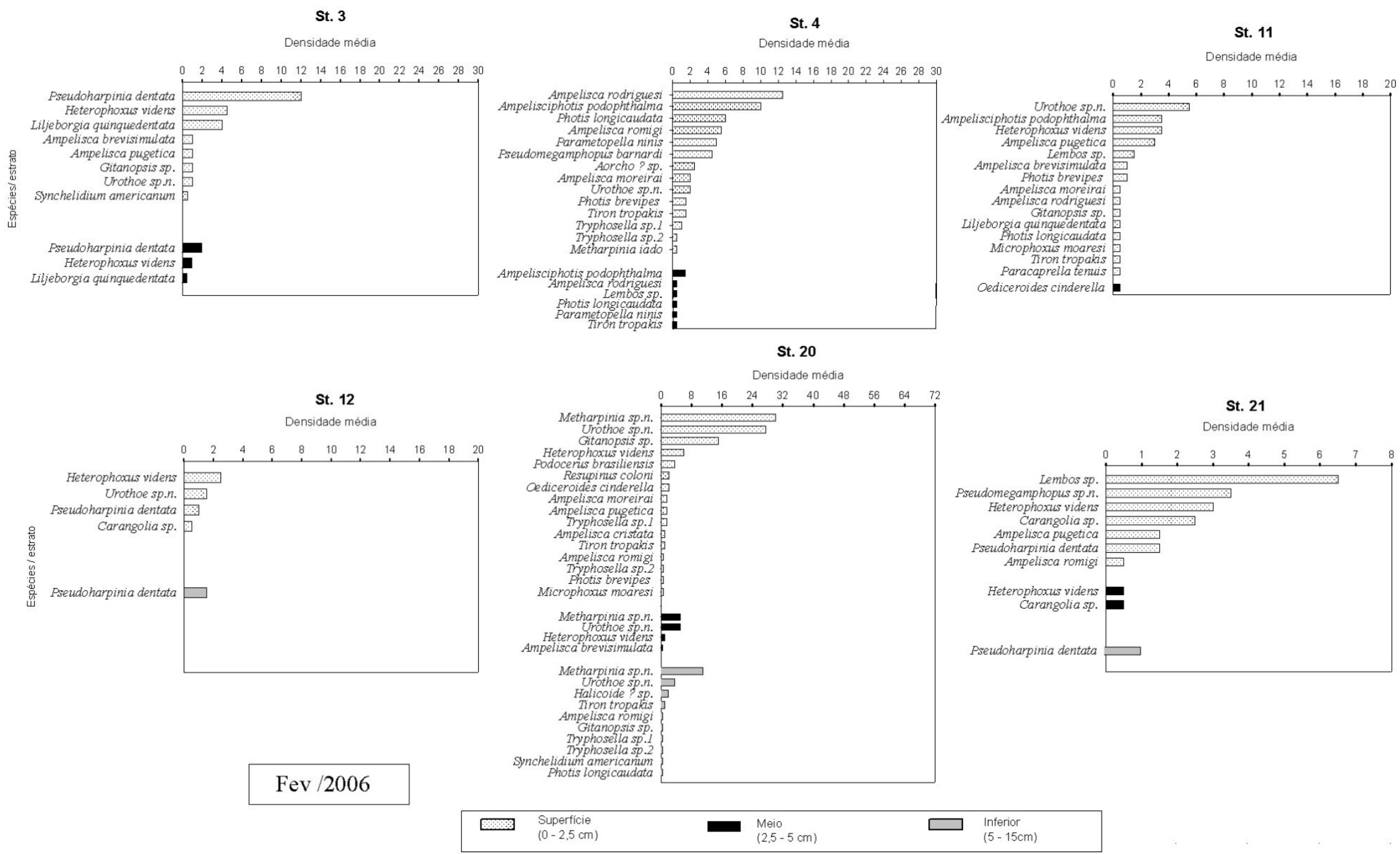

Figura 25 - Distribuição vertical em três estratos das espécies de anfípodes nas estações de verão /2006 amostradas entre as isóbatas de 50 e 100 m na plataforma continental entre São Sebastião e Peruíbe, SP. 


\section{DISCUSSÃO}

\subsection{Fatores Ambientais}

O perfil vertical homogêneo da temperatura e salinidade encontrado nas estações costeiras mais rasas no inverno poderia estar associado aos processos de mistura causados pelo vento e correntes de maré. Segundo Castro et al. (2006) ventos intensos, como aqueles que ocorrem no inverno, podem gerar energia suficiente para misturar verticalmente toda a coluna de água, intensificando os processos de mistura, determinando assim estruturas verticais de densidade mais homogênea, principalmente na parte interna da plataforma continental. Em contraste, a termoclina e haloclina apresentadas pelas estações situadas ao redor de $30 \mathrm{~m}$ indicam a presença de duas massas de água, Água Costeira (AC) e Água Central do Atlântico Sul (ACAS), que apresentam características termoclinas marcantes. Segundo Castro et al. (2008) ocorrem processos de mistura através da frente que separar essas duas massas de água durante o verão, a qual é bem definida nessa época do ano. Em contraposição, durante o inverno a interação entre a AC e a ACAS é praticamente inexistente (CASTRO et al., 2006). As estações amostradas na zona profunda, próximas da isóbata de $100 \mathrm{~m}$, exibiram a presença da massa de água ACAS nas duas campanhas. Segundo Castro et al. (2008) em zonas mais profundas é pequena a variação sazonal das propriedades físicas. Nas proximidades do fundo, os valores de temperatura e a salinidade permanecem próximos de $14^{\circ} \mathrm{C}$ e de 36,4 , respectivamente, durante todo o ano. A água de termoclina observada na plataforma média durante os meses quentes está sempre presente na plataforma externa (CASTRO, 1996).

A entrada e recuo da Água Central do Atlântico do Sul (ACAS) poderam ser observados nas duas campanhas, principalmente quando analisamos os diagramas T-S. Outros estudos na plataforma mostraram que é um fato incontestável que a escala de intrusão subsuperficial da água fria ACAS é maior no verão do que no inverno (CASTRO et al., 1987 e 2006; PIRES-VANIN, 1993; CASTRO, 1996; CASTRO \& MIRANDA, 1998; BRAGA \& NIENCHESKI, 2006; PIRES-VANIN et al., 2008b), demonstrando a existência de uma sazonalidade hidrológica gerada pela entrada e recuo da ACAS nas plataformas interna e média.

Outro fator importante descrito em literatura (CASTRO \& MIRANDA, 1998; CASTRO et al., 2006; 2008) e encontrado no presente trabalho foi a movimentação da Água Tropical (AT), gerada por seu transporte subsuperficial efetuado pela Corrente do 
Brasil (CB). No inverno, uma intrusão subsuperficial da AT em direção ao continente foi mais extensa, com isso pôde-se observar águas mais salinas e quentes próximas à costa. Já no verão ocorreu uma saída da AT em direção à plataforma externa, sendo tal fato observado devido à subsuperfície das estações mais profundas da plataforma média apresentarem salinidades médias maiores que 34 (CASTRO et al., 2008).

O padrão sedimentológico observado no presente estudo mostra que o fundo marinho da área amostrada é formado por altos teores de areia fina e muito fina, estando esses resultados de acordo com o apresentado por Mahiques et al. (1999 e 2004) e Tessler \& Goya (2007). Estes autores apontam que a composição do sedimento das plataformas interna e média, ao sul da ilha de São Sebastião, é principalmente arenosa até a isóbata de $60 \mathrm{~m}$. A partir daí esse sedimento é substituído gradativamente por outros mais finos, e nas proximidades da isóbata de $100 \mathrm{~m}$ torna-se predominantemente lamoso. É nesta última faixa que se situam nossas estações 12 e 21.

Ao se avaliar a distribuição da matéria orgânica total e do carbonato, verificou-se que as estações mais profundas foram as que apresentaram as maiores concentrações dos dois componentes, principalmente no verão. Esses locais foram os que apresentaram os sedimentos mais finos. Os dados obtidos concordam com aqueles apresentados por Mahiques et al. (1999), que sugerem para tais parâmetros um padrão de distribuição fortemente condicionado pelas diferenças geomorfológicas, oceanográficas e fatores sedimentares prevalecentes ao norte e sul da Ilha de São Sebastião. Ao sul da ilha ocorre um aumento marcante da concentração de matéria orgânica em direção às camadas mais profundas da plataforma, como observado neste estudo, principalmente próximo à isóbata de $100 \mathrm{~m}$.

Ainda segundo os mesmos autores, a ausência de grandes modificações no relevo marinho leva a uma ação mais efetiva de ondas sobre a plataforma interna, o que dificulta um depósito de sedimentos lamosos e, conseqüentemente, de matéria orgânica. Isto conduz à ocorrência de um gradiente de matéria orgânica que aumenta em direção à quebra da plataforma. Segundo Tessler \& Goya (2007), que analisaram amostras do mesmo Projeto ECOSAN, devido ao próprio histórico de retrabalhamento desta plataforma ao sul da Ilha de São Sebastião, foi possível também observar altas concentrações de contaminantes nas estações mais lamosas, ou seja, nas proximidades da isóbata de $100 \mathrm{~m}$.

Entretanto, no verão, valores semelhantes de matéria orgânica foram encontrados, tanto nas estações mais profundas como nas estações mais rasas (estações 2, 6, 7, 13 e 18). Estas últimas estações apresentaram uma pequena contribuição de silte e argila o que 
explicaria, em parte, um aumento de matéria orgânica, já que tais frações de pequeno volume, em conjunto, apresentam uma maior área de adsorção para os componentes orgânicos. 0 aumento dos teores de matéria orgânica no sedimento na estação 18 pode ser explicado adicionalmente pela influência de um aporte terrígeno proveniente das regiões estuarinas dos rios Itanhaém, Cananéia-Iguape e do rio Peruíbe, atuantes na região. 0 aumento nos teores de matéria orgânica observado para a estação 13, por sua vez, pode estar vinculado ao posicionamento do local (próximo à desembocadura da Baía de Santos - Figura 1), por onde ocorre o transporte e alguma deposição dos sedimentos provenientes dos estuários que desembocam na baía e da própria baía (PIRES-VANIN et al., 2008b).

Segundo Castro et al. (2006) e Pires-Vanin et al. (2008b) as estações próximas à Ilha da Moela (estações 2, 6, 7 e 9) devem sofrer influência do material de dragagem que é depositado nas proximidades desta ilha e que chega nesses locais devido a ação de correntes costeiras que fluem de sudoeste para nordeste. Ainda, segundo Pires-Vanin et al. (2008b), concentrações relativamente mais altas de contaminantes foram observadas somente nas estações próximas à Ilha da Moela, área de deposição do material de dragagem proveniente do Estuário de Santos, e que também apresentaram granulometria fina, sendo prováveis áreas de deposição do material que vem do estuário.

\subsection{Comunidades de Amphipoda}

\subsubsection{Composição e distribuição da fauna de anfípodes.}

O conhecimento sobre a composição e distribuição dos anfípodes de fundos inconsolidados da plataforma sudeste do Brasil é proveniente de informações retiradas principalmente de trabalhos de cunho taxônomico realizado por poucos autores (WAKABARA et al., 1991; WAKABARA \& SEREJO, 1998; VALÉRIO-BERARDO \& MYAGI, 2000; SEREJO \& LICÍNIO, 2002; VALÉRIO-BERARDO et al., 2005; VALÉRIO-BERARDO \& WAKABARA, 2006). Existe ainda um número menor de informações que vêm de trabalhos ecológicos desenvolvidos para o mesmo ambiente. Desta forma, a composição da fauna de anfípodes da plataforma interna e média da entre São Sebastião e Peruíbe foi similar ao reportado por outros autores para fundo inconsolidados na plataforma da região Sudeste (VALÉRIO-BERARDO, 1992; GALLERANI, 1997; SANTOS, 1999). Esta similaridade pode ser melhor compreendida quando avaliamos as famílias dominantes, no caso Ampeliscidae e Phoxocephalidae. 
Dentro das espécies tubícolas de infauna (gênero Ampelisca), Ampelisca paria foi a única encontrada nas estações costeiras (estações 1, 5, 7, 9, 13, 16 e 18). As demais foram mais freqüentes ao redor das isóbatas de 30 e $50 \mathrm{~m}$.

Ampelisca paria (Família Ampeliscidae) foi a espécie de maior dominância entre todas as estações da zona costeira no inverno e sua alta densidade pode ser observada nas duas campanhas, sendo que neste local foi a única tubícola de infauna encontrada. Os dados obtidos concordam com aqueles encontrados por Serejo et al. (2000), que apontaram esta espécie como restrita a profundidades rasas (4-23m) e substratos arenosos finos a areno-lamosos.

As espécies Ampelisca brevisimulata e Ampelisca pugetica (Família Ampeliscidae) são características de sedimentos areno-lamosos, com ampla distribuição batimétrica (WAKABARA et al., 1991). Segundo Gallerani (1997) e Valério-Berardo et al. (2000b) A. brevisimulata mostrou "preferência" por sedimentos com menores porcentagens de areia grossa, em profundidades médias. Gallerani (1997) reporta também que A. pugetica esteve relacionada principalmente a ambientes com baixos teores de silte. Os resultados do presente estudo concordam com aqueles obtidos por esses autores, sendo que essas espécies, na plataforma ao largo de Santos, distribuiram-se em uma ampla faixa batimétrica, principalmente A. pugetica, e foram relacionadas às estações que apresentaram características areno-lamosas.

$\mathrm{Na}$ plataforma interna Microphoxus moaresi (Família Phoxocephalidae) foi a principal representante das zonas costeira e intermediária, sendo que no verão ocorreu um aumento na sua densidade quando comparada ao inverno. Não foi encontrada em literatura uma associação da espécie a determinado tipo de fundo, porém, segundo Bustamante (2002), ela é característica de zonas rasas (a autora não determina a profundidade). No presente estudo, $M$. moaresi foi encontrada em sedimentos arenosos e em uma ampla faixa batimétrica (15-85 m).

As demais espécies da família Phoxocephalidae ocorreram em estações que apresentavam sedimentos pobremente selecionados e águas mais frias, com alguma influência da ACAS.

Segundo Alonso de Pina (2008) Pseudoharpinia dentata e Heterophoxus videns (Família Phoxocephalidae) podem ser encontradas em sedimentos lamosos e arenosos e em uma ampla faixa batimétrica: 17-522 m para $P$. dentata e 2-1031 m para $H$. videns. A autora também apontou que ambas as espécies apresentam tolerância a temperaturas 
baixas, sendo também encontradas na região Antártica, o que condiz com os baixos valores de temperatura associados à ACAS verificados neste trabalho.

Pseudoharpinia dentata em estudos anteriores para a plataforma continental sudeste, esteve associada à zona costeira (VALÉRIO-BERARDO et al., 2000a, c). No presente estudo essa espécie foi observada nas estações mais profundas e, concordando com o encontrado por Valéio-Berardo et al. (2000a), exibiu co-dominância com H. videns em algumas estações. Segundo a mesma autora $H$. videns esteve associado a sedimentos grosseiros (como areia grossa e muito grossa) e em áreas com forte influência da ACAS. No presente estudo $H$. videns foi encontrada nas mesmas condições acima descritas, assim como em estações que não apresentavam influência da ACAS e tinham predominância em sedimentos mais finos (como silte e argila).

Metharpinia cf. iado (Família Phoxocephalidae), encontrada pela primeira vez no Brasil, foi descrita para as províncias de Buenos Aires (El Rincón) e de Chubut (Golfo San José) - Argentina, e segundo Alonso de Pina (2003) é uma espécie de zona rasa (10-22m) e de sedimentos com maior porcentagem de areia fina a muito fina. No presente estudo Metharpinia cf. iado apresentou baixa densidade e baixa freqüência, ocorrendo em apenas três estações, estações 10 e 15 (inverno e verão - 30 m) e estação 4 (verão - 85 m).

Tiburonella viscana (Família Platyischnopidae) foi encontrada próxima a isóbata de $30 \mathrm{~m}$ (27-34 m) e em sedimentos arenosos. Os dados obtidos estão dentro do habitat previamente relatado por Thomas \& Barnard (1983) e Wakabara et al. (1991) que descreveram este anfípode como uma espécie de zonas rasas, vivendo entre 0 e $27 \mathrm{~m}$ de profundidade e encontrada em sedimentos arenosos a cascalhos.

Eudevenopus gracilipes (Família Platyischnopidae) apresentou maior densidade que T. viscana e foi encontrada em estações costeiras e nas estações próximas a isóbata de $30 \mathrm{~m}$, no intervalo de 14 a $31 \mathrm{~m}$ de profundidade, e em sedimentos que continham alta porcentagem de areia (fina e muito fina). Os dados obtidos mostram que E. gracilipes pode colonizar zonas mais rasas do que as apontadas por outros autores. Segundo De Broyer \& Rauschert (1999) e Chiesa \& Alonso (2007) esta espécie tem sido encontrada entre 30 a $50 \mathrm{~m}$ de profundidade na América do Sul, desde a região de Valparaíso (Chile), Estreito de Magalhães até na região Sudeste-Sul do Brasil. Assim como M. moaresi, não foi encontrado em literatura informações sobre o tipo de sedimento que esta espécie coloniza.

Resupinus coloni (Família Melitidae) foi encontrada entre 13-60 m de profundidade e em estações com alta porcentagem de areia fina e muito fina, e sua maior densidade foi observada na estação 14 (verão). Os dados obtidos no presente estudo ampliam a faixa de 
profundidade em que a espécie pode habitar, complementando assim os dados descritos por Wakabara (1972) e Wakabara et al. (1991). Os autores apontaram que R. coloni é uma espécie de zona costeira (0-15 m) encontrada em sedimentos areno-lamosos.

Segundo Valério-Berardo et al. (2000a) Ampelisciphotis podophathalma (Família Photidae) exibe características de espécie estenobática. No presente estudo ela foi dominante na plataforma média (estações 3, 11 e 4), não apresentando variação temporal. A distribuição encontrada no presente estudo está de acordo com o relatado pelos autores acima mencionados.

Photis brevipes e Photis longicaudata (Família Photidae) apresentam ampla distribuição batimétrica, podendo ser encontradas desde a zona entremarés até $70 \mathrm{~m}$ de profundidade (WAKABARA et al., 1991; VALÉRIO-BERARDO et al., 2000c). Segundo estes autores, essas espécies foram encontradas em substratos predominantemente arenosos e estiveram presentes na plataforma externa de Ubatuba. No presente estudo, ambas apresentaram maior densidade no verão e, apesar de terem sido obtidas em algumas estações profundas $(80 \mathrm{~m})$, a maior densidade de $P$. brevipes esteve vinculada à faixa ao redor das isóbatas de 30 e 50 m (24-58 m) e P. longicaudata apresentou maior freqüência na zona costeira (14-25 m).

Photis longicaudata, como mostrado anteriormente nos resultados, foi encontrada habitando conchas vazias de outros invertebrados. Concordando com dados existentes na literatura para outros anfípodes tubícolas (CARTER, 1982; JUST, 1988). Segundo esses autores Photis conchicola, Siphonoecetes sabatieri, S. tanabensis e S. dellavallei (Família Ischyroceridae) também utilizam conchas vazias em fundos arenosos. $P$. conchicola ao encontrar a concha, tende a se fixar em plantas marinhas, enquanto que as espécies de Siphonoecetes tendem a se enterrar na areia.

Quatro vantagens estão relacionadas a este tipo de comportamento. Primeiro, diferentemente do que ocorre com os grandes ermitões (Crustacea: Anomura: Paguridae), os pequenos Photis e Siphonoecetes parecem não ter dificuldade em encontrar diminutas conchas de gastrópode para utilizar, e assim sendo, os dados indicam que as conchas parecem não agir como fator limitante para sua ocorrência em determinadas áreas. Em segundo lugar, a utilização de conchas teria a função de evitar flutuações de temperatura e salinidade, a que o animal estaria sujeito se estivesse fora dela, principalmente em regiões entremarés. Terceiro, os machos podem segurar as fêmeas por muitos dias e, pela cohabitação no mesmo domicílio, a probabilidade de fertilização aumentaria. Por último, com a capacidade de habitar conchas estas espécies reduziriam a predação, o que 
acarretaria o aumento de sua sobrevivência. Contudo, para as espécies de Siphonoecetes, acredita-se que o mais importante seja o aumento de peso que o organismo adquire com a concha, permitindo-lhes uma melhor estabilidade na superfície do sedimento (CARTER, 1982; JUST, 1988).

A associação encontrada neste estudo entre $P$. longicaudata e vermes sipunculídeos não havia sido ainda descrita em literatura. Especula-se que o tipo de relação biológica existente entre estes dois grupos não tenha relação direta com proteção, sendo necessários maiores estudos futuros sobre o assunto. Vader (1983) fez uma revisão sobre a associação de anfípodes de diferentes famílias com anêmonas e mostrou que $P$. longicaudata pode se associar com Cerianthus lloydii (MOORE \& CAMERON, 1999). Segundo o autor o tipo de associação parece fornecer aos anfípodes apenas a proteção contra possíveis predadores.

Liljeborgia dubia, Liljeborgia quinquedentata e Listriella titinga (Família Liljeborgiidae) estão dentre as principais espécies inquilinas, ou "nestlers", encontradas no presente estudo. Segundo Wakabara et al. (1991) todas elas são características de sedimento lamo-arenoso, variando apenas no intervalo batimétrico. L. titinga tem sido encontrada da região entremarés até $27 \mathrm{~m}$, L. dubia até $65 \mathrm{~m}$ e L. quinquedentata até 790 m de profundidade. Os dados obtidos situam-se dentro desses intervalos, exceto para $L$. titinga está sendo aqui relatada para profundidade maior do que a previamente citada (56 metros).

Outras três espécies, Kamehatylus sp. (Família Dexaminidae), Gitanopsis sp. (Família Amphilochidae) e Parametopella ninis (Família Stenothoidae) foram consideradas inquilinas ou "nestlers". Kamehatylus sp. engloba um grupo de anfípodes inquilinos que ocorrem principalmente em regiões tropicais ou temperadas quentes e, apesar de serem basicamente de vida livre, estes organismos são tipicamente lentos ou mesmo sedentários, com a maioria das espécies de hábito alimentar detritívoro (BOUSFIELD \& KENDALL, 1994). Kamehatylus sp. foi encontrada até a isóbata de $30 \mathrm{~m}$ (faixa batimétrica 13-27 m) e em sedimentos arenosos; Gitanopsis sp. foi obtida acima da isóbata de 30 m (26-85 m) e em estações lamo-arenosas. As espécies Gitanopsis sp. e Kamehatylus sp. foram encontradas na região pela primeira vez, sendo que a única ocorrência de espécies dessas famílias (Amphilochidae e Dexaminidae) era restrita a Amphilocus neopolitanus e Atylus minikoi (WAKABARA et al., 1991; WAKABARA \& SEREJO, 1998). Parametopella ninis, encontrada na mesma faixa batimétrica que Gitanopsis sp., foi obtida apenas no verão. Ao contrário das outras espécies, $P$. ninis já foi encontrada em estudos realizados na 
plataforma continental ao largo de Ubatuba (VALÉRIO-BERARDO, 1992; GALLERANI, 1997 e SANTOS \& PIRES-VANIN, 2000), na mesma faixa batimétrica (18-116 m) e em substratos lamo-arenosos. Desta forma, os dados obtidos para esta espécie, no presente estudo encontram-se de acordo com o que já foi relatado.

6.2.2 Fatores estruturadores das comunidades de anfípodes e determinantes da sua distribuição

A composição e a distribuição espacial dos anfípodes de uma região estão relacionadas, tanto a um gradiente ambiental composto pelas variáveis abióticas e à disponibilidade de alimento, quanto às relações inter e intra-específicas (POSEY, 1987; SCHAFFNER \& BOESCH, 1982). Variações na densidade e na riqueza de espécies na SuperOrdem Peracarida, principalmente os anfípodes já foi observado em sedimentos inconsolidados de regiões temperadas (CUNHA et al., 1999; REISS \& KRÖNCKE, 2005). Estas flutuações foram relacionadas com a composição sedimentar, temperatura da água, profundidade, hidrodinamismo, disponibilidade de alimento e o ciclo de vida das espécies (CUNHA et al., 1999). Estudos realizados na região tropical do Brasil, principalmente na plataforma de Ubatuba (SP) e da Bacia de Campos (RJ), indicaram que as variáveis ambientais mais importantes na estruturação das comunidades de anfípodes foram as variações na profundidade e a composição sedimentar, e que os fatores hidrológicos como a temperatura, ligados a massas de águas, também influenciam a distribuição e composição desta fauna (VALÉRIO-BERARDO, 1992; GALLERANI, 1997; SANTOS \& PIRESVANIN, 2000; VALÉRIO-BERARDO et al., 2000a, c). Com os dados obtidos no presente estudo podemos sugerir que as massas de água, profundidade e composição sedimentar são os principais fatores na composição e distribuição dos anfípodes na plataforma interna e média, assim como apontado em outros estudos citados anteriormente.

O Grupo I de ambas as campanhas caracterizou-se pela presença de uma comunidade típica de zona costeira (plataforma interna) com baixos valores de densidade e diversidade, formada por espécies que habitam uma região com alto grau de hidrodinamismo, fator mais acentuado no inverno quando ocorre a passagem de frentes frias freqüentes (PAIVA, 1993a; GALLERANI, 1997). Os baixos valores de diversidade, característicos deste grupo da zona costeira, também foram apontados em outros trabalhos (PAIVA, 1993a; PIRES-VANIN, 1993; SANTOS \& PIRES-VANIN, 2000; VALÉRIOBERARDO et al., 2000a, b; GRAY, 2002; CAPÍTOLI \& BEMVENUTI, 2004; HOEY et al., 2004). Segundo esses autores, na plataforma interna, principalmente no inverno, ocorrem muitos processos de perturbação que contribuem para os baixos valores de diversidade de 
anfípodes, assim como outros organismos da macrofauna. Entre estes processos o mais importante é o revolvimento do sedimento de fundo induzido por ondas de superfície que são restritas na plataforma interna. Estas ondas são geradas pelos fortes ventos do sul e do sudeste, característicos de zonas pré-frontais de sistemas de frentes frias, freqüentes durante os períodos de inverno. Capítoli \& Bemvenuti (2004) apontam que em ambientes com perturbações constantes não é atingido o desenvolvimento completo da comunidade, sendo poucas espécies tolerantes a esses distúrbios. Segundo Valério-Berardo et al. (2000b), tais processos na plataforma de Ubatuba afetam principalmente os anfípodes tubícolas de epifauna que são mais sensíveis a mudanças nas condições do sedimento superficial.

A espécie que se destacou nessa zona costeira foi Ampelisca paria, um espécie tubícola de infauna. A dominância de A. paria sobre outras espécies de anfípodes, principalmente cavadores, foi verificada também por Santos \& Pires-Vanin (2000) para a região em torno da Ilha de São Sebastião. Todavia, os resultados obtidos tanto por essas autoras como no presente estudo, não estão de acordo com aqueles apontados por outros estudos (BIERNBAUM, 1979; VALÉRIO-BERARDO, 1992; GALLERANI, 1997). Esses autores relacionam a presença de organismos cavadores à ambientes com hidrodinâmica mais acentuada. Ainda os autores sugerem que ambientes onde ocorre a desestabilização favorecem cavadores, pois estes têm a capacidade de se reestruturar após essa desestabilização.

A alta densidade de Ampelisca paria parece estar vinculada a zona com alto hidrodinamismo, como apontado acima e que gera uma desestabilização no sedimento principalmente no inverno. Quando analisamos os gráficos de densidade das espécies nos estratos nas duas campanhas, observamos que no inverno A. paria exibiu maior densidade no estrato de superfície e esteve presente em todos os estratos. A sua maior densidade no estrato de superfície pode estar relacionada à maior rapidez que esta espécie apresenta em recolonizar áreas recém perturbadas, quando comparada com outros anfípodes, sugerindo que esta espécie apresenta comportamento oportunista. Segundo Paiva (1990) e Valério-Berardo (1992) ocorreu uma tendência de distribuição de espécies oportunistas na plataforma interna de Ubatuba, assim como o que foi encontrado na mesma área do presente estudo. Ainda a presença de A. paria em outros estratos principalmente no inverno, aponta que ela consegue refugiar-se dentro de seu tubo em estratos mais profundos na tentativa de se proteger contra os distúrbios comuns nesta época do ano. No verão com a diminuição dos distúrbios que geram a desestabilização do sedimento, um número maior de espécies coloniza as estações, apesar de $A$. paria ainda exibir uma 
dominância na maioria das estações, ela não é encontrada em todos os estratos da coluna sedimentar.

Outro fator que pode ser considerado responsável pela dominância de A. paria no inverno e sua diminuição no verão é a relação inversa que pode ocorrer entre tubícolas de infauna e cavadores (POSEY, 1987; POSEY et al., 2002). Espécies com padrões similares de utilização de recurso podem alterar o ambiente e torná-lo mais favorável as outras formas ecologicamente diferentes (POSEY, 1987; WILSON, 1991). Estas relações negativas ocorrem pela estabilização dos sedimentos causados pelas grandes densidades de organismos tubícolas ou desestabilização dos sedimentos causados pelas altas densidades de cavadores, inibindo assim a presença de um e de outro (POSEY et al., 2002).

A diferença na densidade de A. paria em algumas estações (estações 9 e 18) no verão pode ter sido uma resposta à diminuição dos valores de salinidade, à presença de contaminantes e ainda à um aumento na predação.

Segundo Bícego \& Montone (2007) e Tessler \& Goya (2007) que estudaram amostras do Projeto ECOSAN, nas estações próximas à Ilha da Moela, principalmente estações 7 e 9, houve a presença de contaminantes no sedimento, pois esta área é o local onde é depositado o material dragado do Canal do Porto de Santos. A presença de contaminantes nestas estações poderia também explicar a ausência de Ampelisca paria (estação 9) e diminuição da sua densidade nas estações próximas da ilha (principalmente estação 7 no verão). Outros resultados com relação à diminuição da abundância da megafauna e meiofauna nestas estações, principalmente estação 9, também foram observadas por Pires-Vanin et al. (2008a) e Corbisier et al. (2008).

Contaminantes que poderiam afetar a biota já foram encontrados por outros autores na Baía de Santos e na área próximo a sua desembocadura (ABESSA et al., 2005; CESAR et al., 2007; MARTINS et al.,2008). Abessa (2002) que realizou testes de toxicidade na Baía de Santos e na sua desembocadura com espécies de Tiburonella viscana, aponta que a acumulação de contaminantes no sedimento pode produzir toxicidade para a biota bentônica e ameaçar o balanço do ecossistema, e ainda que a combinação de metais e detergentes no sedimento sejam responsáveis dos efeitos tóxicos observados nos testes. Como o material despejado próximo a Ilha da Moela tem a mesma origem daqueles observados pelos autores mencionados acima, na Baía de Santos, acredita-se que esta contaminação tenha afetado a densidade dos anfípodes na estação 9.

Em relação à estação 18, no verão, provavelmente ocorreu um aumento na eutrofização na área devido ao grande aporte de matéria orgânica de origem continental 
proveniente do sistema estuarino Cananéia - Iguape e do rio Peruíbe, junto com os detritos orgânicos vindos do banco de Bugula turrita (PIRES-VANIN et al., 2007). Contudo, apesar desse aporte foi observada uma diminuição na densidade de Ampelisca paria, possivelmente devido a uma resposta do aumento na predação que esta espécie pode sofrer neste período e aos baixos valores de salinidade, resultado do maior aporte de água doce dos rios da região no verão.

Somado a isso, sabe-se que a predação por peixes demersais e outros organismos pode favorecer enormemente o declínio no número de peracaridas em determinadas épocas do ano, como verificado por Thiel, 1997, Branco \& Moritz, 2001 e Moreira et al., 2008. Segundo Schaffner \& Boesh (1982) e Thiel (1997) organismos tubícolas, tanto de infauna quanto de epifauna, principalmente anfípodes das famílias Ampeliscidae e Corophiidae, são mais suscetíveis à predação do que os cavadores. No presente estudo podemos apontar dois predadores naturais da megafauna para os anfípodes presentes na região. Segundo Pires-Vanin et al. (2008a), ocorreu uma alta densidade de Xiphopenaeus kroyeri (camarão sete-barbas) e Portunus spinimanus (siri-bóia), nas estações da plataforma interna, especialmente mais ao sul da área (estações 16 e 18). Segundo Branco \& Moritz (2001) e Branco \& Lunardon-Branco (2002) os gammarídeos são um dos itens principais da dieta alimentar destes organismos (X. kroyeri e P. spinimanus) no litoral brasileiro, devido à sua disponibilidade no meio ambiente e/ou facilidade de captura e processamento.

Os baixos valores de salinidade encontrados na estação 18 também poderiam explicar a diminuição no número de Ampelisca paria e no aumento na densidade de Microphoxus moaresi (cavador). Com isso podemos sugerir que A. paria apesar de demonstrar ser uma espécie oportunista, pode ser tolerante a baixos valores de salinidade e M. moaresi por ser uma espécie cavadora, consegue suportar melhor as flutuações de salinidade características de época do ano, onde ocorre um aumento da pluviosidade.

A plataforma média (PM) e externa (PE) de Ubatuba, que se assemelha a PM do presente estudo, foi descrita como uma plataforma estável e com perfil ambiental uniforme junto ao fundo durante todo o ano, estando o fundo sob influência da ACAS na maior parte do ano. Isto significa menores variações da temperatura, salinidade, oxigênio e velocidade das correntes. Não há aqui um revolvimento marcante do fundo, que é característico em zonas rasas, e é uma fonte de ressuspensão e transporte dos animais epifaunais (PIRES-VANIN, 1993; VALÉRIO-BERARDO et al., 2000a). Essa estabilidade 
permitiria a manutenção de uma comunidade mais diversificada e estável, dominada por espécies tubícolas de epifauna e infauna (VALÉRIO-BERARDO et al., 2000a).

A plataforma média do presente estudo (formada pelos grupos III e IV) apresenta as mesmas características daquelas descritas pelos autores acima, com a presença da ACAS no fundo durante todo o ano e uma comunidade mais diversificada no inverno. Apesar dos organismos tubícolas de infauna dominarem na estação 4 e os tubícolas de epifauna dominarem na estação 21, conforme o padrão apontado acima, a maior parte das estações destes grupos exibiu uma dominância de anfípodes cavadores.

As espécies cavadoras que dominaram estes grupos foram Pseudoharpinia dentata, Heterophoxus videns e Urothoe sp.n. A alta concentração destas espécies em maiores profundidades também foi observada por Gallerani (1997), que ainda relatou a presença de espécies de vida livre e inquilinos associados com as cavadoras, fato também encontrado no presente trabalho.

Valério-Berardo et al. (2000a), estudando a plataforma de Ubatuba, encontraram $P$. dentata associada a fundos lamosos na plataforma interna ao sul (próximo a Ilha de São Sebastião) e na plataforma externa no inverno. Os autores também citam que a espécie demonstra tolerância a variações de temperatura sendo encontrada em áreas com influência tanto da AC quanto da ACAS. Além disso, H. videns também foi encontrado em áreas com sedimento mais grosseiro e com forte influência da ACAS. Como citado anteriormente, ambas as espécies são tolerantes a baixas temperaturas, sendo encontradas em regiões Antárticas (WAKABARA et al., 1990; ALONSO DE PINA, 2008). No presente estudo $H$. videns esteve associado a todas as estações que apresentaram forte influência da ACAS tanto no inverno quanto no verão, contudo, sua presença não esteve vinculada a sedimentos grosseiros como apontados por outros autores Valério-Berardo et al. (2000a). Já $P$. dentata esteve associada a fundos lamosos apenas no verão, onde cohabitou com $H$. videns em todas as estações e no inverno a mesma esteve mais associada a fundos arenosos. Estes resultados sugerem que talvez estas espécies sejam mais influenciadas pelas massas de água, principalmente ACAS, presentes na plataforma sudeste do que pela granulometria do sedimento.

O Grupo II das duas campanhas pode ser considerado como um grupo intermediário e/ou de transição entre a zona costeira e zona profunda. Nessa faixa intermediária uma variação sazonal que se resume a influência da ACAS na região (entrada e recuo da ACAS) e da zona de mistura entre as massas AC e ACAS sobre a composição faunística. Tal faixa de transição também foi observada na plataforma de 
Ubatuba por Pires-Vanin (1993). Essa faixa de transição ambiental marcada sazonalmente por diferentes graus de mistura entre AC e ACAS, contém uma composição mista de espécies, que apresentam diferentes tipos de mobilidade, e é ocupada predominantemente por espécies euribáticas, euritérmicas e eurihalinas vivendo em fundos de areia fina ou areia muito fina. A maior porcentagem de sedimentos arenosos observada nesta área poderia acarretar uma maior diversidade na área, principalmente no verão. Marques \& Bellan-Santini (1993) e Valério-Berardo et al. (2000c) apontaram que sedimentos arenosos, sustentam uma maior densidade e diversidade de anfípodes quando comparados com sedimentos lamosos, como aqueles encontrados em algumas estações na parte externa da plataforma média do presente estudo (estações 12 e 21).

Apesar deste grupo apresentar uma diversidade maior que a verificada para o Grupo I, Ampelisca paria dominou na maior parte das estações do inverno. Porém, ao contrário do que se observou no Grupo I, a sua dominância foi fraca e insuficiente para diminuir ou excluir outras espécies com diferentes tipos de mobilidade. A dominância de A. paria diminuiu no verão, quando foi possível observar uma maior equitiatividade entre as espécies e entre os hábitos alimentares: cavadores, tubícolas de infauna e mesmo inquilinos como caso de Gitanopsis sp., da estação 15.

A composição de espécies, os dados de densidade e diversidade refletem diferenças distintas na distribuição de anfípodes em relação à latitude e distância da costa (VALÉRIO-BERARDO et al., 2000c). Parece que, primariamente a presença da massa de água ACAS e AC e a profundidade, e secundariamente outros fatores são os responsáveis por esta distribuição. A influência da ACAS provavelmente ocorre através de seu papel eutrofizador. Sendo rica em nutrientes ao penetrar na região costeira durante o verão, promove intensa eutrofização, com conseqüente aumento na produção primária e maior aporte de alimento que chega até o bentos, conseqüentemente levando a um aumento na densidade e diversidade de anfípodes. Além disso, após a estratificação da coluna de água no verão, causada pela entrada da ACAS, ocorre um período de estabilização e de farto alimento, o qual pode fazer com que a comunidade aumente em densidade. A diversidade pode ser favorecida pela chegada de espécies de locais próximos a essas áreas de alimentação.

\subsubsection{Estrutura funcional das comunidades de anfípodes}

Estudos prévios realizados na plataforma sudeste brasileira (GALLERANI, 1997; VALÉRIO-BERARDO, 1992; VALÉRIO-BERARDO et al., 2000b) relacionaram a maior 
densidade de anfípodes tubícolas de infauna e epifauna com ambientes profundos, caracterizados por sua maior estabilidade durante o ano inteiro e por serem constituídos de sedimentos médios a finos, onde a porcentagem de areia fina, muito fina e silte foram maiores. Contudo os resultados obtidos no presente estudo relacionados aos tubícolas de infauna (Família Ampeliscidae, gênero Ampelisca), apontam para sua ocorrência em uma faixa batimétrica ampla entre a plataforma interna e média (zona costeira, intermediária e profunda) e não somente em zonas profundas. De maneira geral também, as espécies estiveram presentes em todos os tipos de sedimento e puderam ser associados às diferentes condições oceanográficas presentes na área de estudo.

Segundo Valério-Berardo (1992), Dauvin et al. (1993) e Dauvin (1998) as espécies de Ampelisca freqüentemente vivem simpatricamente, ou seja, ocorrem no mesmo local e são simultaneamente abundantes. Embora a simpatria tenha sido observada em algumas estações, Ampelisca paria não apresentou tal comportamento, pois a alta densidade, principalmente na zona costeira não foi compartilhada com as demais espécies do gênero.

Os anfípodes tubícolas de epifauna ocorreram em todos os grupos de estações com diferentes densidades, sendo mais comuns nas estações 4 e 21. Porém, não foi possível observar uma tendência definida de distribuição espacial, em relação à composição sedimentar e à profundidade. Valério-Berardo (1992) apontou a existência de variação sazonal na densidade desses organismos, relacionando-a à presença da ACAS e ao possível aumento de fitoplâncton. 0 presente estudo, mostra que em nem todas as estações que sofreram a influência da ACAS houve um aumento na densidade dos tubícolas de epifauna, tendo o aumento ocorrido apenas nas estações 4 e 14 no verão. Isso parece indicar que um conjunto maior de fatores bióticos e abióticos e não somente a ACAS e o aumento do fitoplâncton sejam condicionadores da distribuição das espécies nos grupos, em obra estes dois últimos possam ser os principais.

Ao contrário do descrito para anfípodes tubícolas da infauna, Biernbaum (1979) relaciona a presença de organismos cavadores a ambientes com hidrodinamismo mais intenso. 0 revolvimento constante do fundo seria desfavorável aos organismos tubícolas, o que facilitaria a ocupação do ambiente sedimentar pelos cavadores. Apesar de não ser possível realizar medidas sobre a velocidade das correntes nas estações em que os cavadores estiveram presentes, pode-se inferir que a zona costeira sendo mais rasa tornase mais influenciada por ventos e outros fatores metereológicos, em relação à zona mais profunda. Entretanto, nossos dados diferem daqueles relatados por Biernbaum (1979), uma vez que este autor obteve menor densidade de anfípodes cavadores em zona mais 
profunda, onde se não acredita apresentar um alto hidrodinamismo como verificado na zona costeira.

Segundo Biernbaum (1979) e Gallerani (1997), os anfípodes de vida livre apresentaram maior densidade na plataforma média, nos locais em que ocorreram maiores teores de carbonato e cascalho, e os valores menores ou nulos de silte. No presente estudo, podemos relacionar algumas estações (estações 3, 4, 10 e 21) que apresentaram valores maiores médios de carbonato com a presença de anfípodes de vida livre, contudo as porcentagens médias de silte apresentaram valores baixos apenas nas estações 3, 4 e 10. Dessa maneira, os anfípodes de vida livre apresentaram uma leve tendência de distribuição associado com as porcentagens de carbonato definida na área estudada.

Os inquilinos representados pelas famílias Liljeborgiide (Liljeborgia dubia, Liljeborgia quinquedentata e Listriella titinga), Dexaminidae (Kamehatylus sp.), Amphilochidae (Gitanopsis sp.) e Stenothoidae (Parametopella ninis) não apresentaram uma tendência definida de distribuição em relação à composição sedimentar e apresentaram-se em maior concentração no grupo de estações da zona de transição entre as zonas rasa e profunda (estações ao redor da isóbata de 30m). Gallerani (1997) mostrou que as espécies inquilinas da Bacia de Campos também estiveram associadas às áreas rasas, apesar das diferenças existentes na composição sedimentar de ambos os estudos.

\subsubsection{Distribuição vertical.}

Os anfípodes costumam exibir grande complexidade trófica, sendo que sua distribuição espacial e vertical no sedimento pode ser um reflexo das afinidades existentes entre os diferentes grupos tróficos encontrados (DAUBY et al., 2001; DE BROYER et al., 2003; YU et al., 2003).

Apesar dos anfípodes serem freqüentemente encontrados sobre a superfície do sedimento, várias espécies conseguem viver a muitos centímetros abaixo dessa superfície, desenvolvendo para isso mecanismos de locomoção e hábitos alimentares particulares.

Devido à bioturbação gerada principalmente pelos organismos infaunais detritívoros, uma parte da matéria orgânica é misturada em camadas mais profundas do sedimento, onde a anóxia diminui a taxa de decomposição. A redistribuição da matéria orgânica dentro do sedimento pela bioperturbação das espécies da macrofauna irá influenciar a distribuição vertical assim como a estrutura da comunidade bêntonica (HARGRAVE, 1970; DAUWE et al., 1998). Indicadores mostram que detritívoros diferem 
no uso da matéria orgânica recém depositada e na matéria orgânica antiga presentes no sedimento (BYRÉN et al., 2006).

Com base nessas informações esperava-se obter uma diminuição de anfípodes na coluna sedimentar, da superfície em direção ao inferior e que no estrato inferior, o mais próximo da camada REDOX, ocorresse apenas os anfípodes infaunais mais tolerantes à baixa concentração ou à deficiência de oxigênio. Nesse caso, esses organismos quando não tubícolas de infauna, seriam representados por espécies cavadoras.

A diminuição na densidade e diversidade de anfípodes do estrato de superfície para o inferior da coluna sedimentar realmente foi observada, sendo que o estrato de superfície foi o que apresentou maior densidade e diversidade. Os altos valores de densidade e diversidade neste estrato estão relacionados, não só aos anfípodes, mas à macrofauna de um modo geral, e refletem as condições favoráveis da zona de interface coluna de água/sedimento, como maior disponibilidade de oxigênio e de matéria orgânica, de origem alóctone ou autóctone, como observado em outros trabalhos (FLACH \& HEIP, 1996; DAUWE et al., 1998; MUCHA \& COSTA, 1999; MUCHA et al., 2004; VENTURINI, 2007; QUINTANA, 2008).

Espécies com diferentes tipos de mobilidade foram observadas em todos os estratos e proporcionalmente nenhuma mobilidade específica foi acentuadamente dominante nos diferentes estratos amostrados. Apesar dos resultados terem comprovado uma diminuição nos valores de densidade e diversidade com aumento da profundidade do sedimento, algumas estações apresentaram nos seus estratos inferiores espécies de grupos funcionais que parecem estar mais relacionadas com o estrato de superfície (BOUSFIELD \& KENDALL, 1994; DAUWE et al., 1998; DAUBY et al., 2001). Este é o caso, por exemplo, dos organismos epifaunais (vida livre e inquilinos) - Liljeborgia quinquedentata e, Gitanopsis sp. e de Lembos sp., Cheirophotis neotropicalis e Photis longicaudata, estes três últimos tubícolas de epifauna.

No presente estudo uma densidade maior de organismos suspensívoros e depositívoros de subsuperfície foram encontrados na zona rasa, o que é esperado em ambientes que sofrem eutrofização e possuem uma alta carga de detritos orgânicos, já que a medida que o enriquecimento orgânico aumenta a comunidade tende a ser dominada pelos deposítivoros (BEUKEMA, 1991). Porém, algumas estações apresentaram baixo teor de matéria orgânica no sedimento, isso deve dar uma oportunidade para os suspensívoros nessa zona rasa, que apresenta fortes correntes de maré que mantém a maioria da matéria orgânica em suspensão (DAUWE et al., 1998). A ocorrência de todos os grupos na zona 
intermediária no presente estudo, ou seja, ao redor da isóbata de $30 \mathrm{~m}$, indica um sistema bentônico com uma estrutura funcional relativamente equilibrada e complexa, submetida à contaminação orgânica e estresse hidrodinâmico intermediários (DAUWE et al., 1998). Além disso, uma alta diversidade trófica pode ser atribuída a uma alta variabilidade do alimento em termos de quantidade, qualidade e origem (WIEKING \& KRÖNCKE, 2005).

Os resultados no presente trabalho levantam a questão se as espécies de anfípodes classificadas como epifaunais ou tubícolas de epifauna podem ser consideradas restritas à zona interface coluna de água/sedimento, ou seja, aos primeiros centímetros do sedimento (estrato de superfície), ou se conseguem mudar seu modo de vida em resposta à bioperturbação gerada por outros organismos da macrofauna (como por exemplo poliquetos) e/ou à disponibilidade de matéria orgânica e oxigênio presentes no sedimento, ou ainda em alguns casos, se passam a apresentar algum tipo de comensalismo com outras espécies tubícolas.

Uma das estratégias mais comuns para a compreensão da existência e manutenção das comunidades é a investigação das guildas tróficas. 0 conhecimento dos hábitos alimentares das espécies, em particular dos crustáceos é de fundamental interesse, porque a disponibilidade e a utilização do alimento influem diretamente em seus padrões de distribuição horizontal e/ou vertical no sedimento. 0 estudo dos padrões tróficos em comunidades de substratos inconsolidados tem sido desenvolvido principalmente com poliquetos, com ênfase secundária nos demais grupos (CALIL, 2005). 0 ecofuncionamento e especificidade trofodinâmica dentro dos anfípodes é ainda pobremente conhecida. Menos de $10 \%$ das espécies foram estudadas e a maior parte dos estudos foram realizados com espécies antárticas. Além disso, para a maioria dos grupos o tipo de alimento freqüentemente não pode ser inferido com base na morfologia dos apêndices bucais. A esta premissa existe uma única exceção, encontrada na Superfamília Lysianassoidea, cujas espécies possuem uma estrutura mandibular particular com um molar especializado para a necrofagia (DAUBY et al., 2001).

Segundo Beare \& Moore (1994; 1998) e Yu et al. (2002; 2003) espécies dos gêneros Monoculodes e Synchelidium (Família Oedicerotidae) são muito ativas e quando se enterram no substrato exibem uma preferência de permanecer na subsuperfície do sedimento, deixando apenas a cabeça exposta. Segundo estes mesmos autores, esses organismos mostraram possuir facilidade em mudar de dieta segundo a disponibilidade de alimento no ambiente. Assim, em algumas situações exibem dieta carnívora, 
principalmente composta por copepodes harpacticoides, diferentemente do modo de vida obrigatoriamente detritívoro no qual eram descritos anteriormente.

Dauby et al. (2001) e De Broyer et al. (2003), por sua vez, consideraram espécies do gênero Oediceroides (Família Oedicerotidae) e do gênero Liljeborgia (Família Liljeborgiidae) como organismos da infauna ou epibentos, porém menos ativos, sendo também classificadas como detritívoras que podiam mudar para predadores. Esses autores esclarecem que esses organismos podem ter dietas duplas, se alimentando de grandes partículas presentes no sedimento, mas também complementando a dieta com pequenos organismos do bentos, tais como poliquetos e anfípodes.

Com base nas informações acima se esperou encontrar estes quatro indivíduos (Synchelidium, Monoculodes, Oediceroides e Liljeborgia) detritívoros de subsuperfície e carnívoros nos primeiros estratos (superfície e meio), e principalmente no estrato de superfície e sua ausência no estrato inferior. Contudo, apesar de comprovada a maior densidade no estrato de superfície todos os quatro indivíduos foram encontrados nos estratos inferiores. Dessa maneira, podemos inferir que estas espécies não estão restritas à superfície ou subsuperfície do sedimento conseguindo atingir estratos mais profundos do sedimento, seja devido à disponibilidade de alimento, para diminuir a ação de predadores ou de perturbações locais no ambiente.

Experimentos em laboratório mostraram que espécies do gênero Urothoe (Família Urothoidae) comparadas a outros anfípodes não apresentam atividade de natação, e quando coletados em tanques exibem comportamento de se enterrar no sedimento. Muitas vezes podem ser encontradas a 5 ou $7 \mathrm{~cm}$ da camada superficial (CALLAWAY, 2006). A facilidade de alcançar camadas mais profundas está relacionada com seu pequeno tamanho e o fato de se enterrar no sedimento sem a necessidade de construir galerias como outros organismos de infauna. Este comportamento foi encontrado para as espécies de Urothoe do presente estudo. Nas estações em que foi encontrada a espécie conseguiu se aprofundar até aproximadamente $5 \mathrm{~cm}$ (soma dos estratos de superfície e meio), sendo que na estação 20 de verão alcançou o estrato inferior $(10 \mathrm{~cm}$ de profundidade).

Giberosus myersi (Família Melitidae) está relacionado aos organismos de infauna suspensívoros passivos que permanecem parados na zona de subsuperfície do sedimento com os apêndices, incluindo urópodos, diretamente voltados para a coluna de água, alimentando-se de partículas que sedimentam da coluna de água. Permanecendo nesta posição o organismo consegue se locomover horizontalmente no sedimento e consegue 
processar a matéria orgânica que eventualmente cai no espaço formado pela cabeça e urópodos (BARNARD, 1988). Segundo Thomas (1993) Resupinus coloni, que pertence à mesma família, apresenta o mesmo comportamento acima descrito, pois as duas espécies são morfologicamente semelhantes. No presente estudo as duas espécies exibiram maior densidade no estrato de superfície, porém foram encontrados indivíduos em outros estratos.

No presente estudo Tiron biocellata apresentou sua maior densidade no estrato inferior (estação 10 - inv.). Oliver \& Slattery (1985), estudando a resposta do bentos para a perturbação gerada pela baleia cinza no solo marinho, verificou que T. biocellata é uma espécie oportunista caracterizada por apresentar alta mobilidade de natação e ser encontrada na superfície e subsuperfície do sedimento, respondendo rapidamente a perturbações nesse ambiente. Segundo os mesmos autores, T. biocellata aproveita perturbações recentes no sedimento e assim como outras espécies oportunistas, coloniza rapidamente a área. Ainda, a espécie pode utilizar tubos de outros organismos alcançando maiores profundidades na coluna sedimentar (OLIVER \& SLATTERY, 1985). Com estas informações podemos sugerir que a ocorrência de T. biocellata no estrato inferior esteja ligada ao seu comportamento oportunista e à ocupação de tubos de poliquetos presentes no substrato.

Segundo Myers \& Lowry (2003) Podocerus brasiliensis apresenta comportamento oportunista semelhante à $T$. biocellata, podendo também ser encontrada em tubos de outros anfípodes. No presente estudo não se observou P. brasiliensis em tubos de outros organismos, contudo podemos inferir que ela ocorreu apenas no estrato de superfície e associada a outras espécies tubícolas de epifauna, como Lembos sp., Corophiidae cf. Leptocheirus e Pseudomegamphopus sp.n.

Os anfípodes pertencentes à Família Phoxocephalidae são membros estruturadores importantes para sedimentos inconsolidados desde as zonas rasas até as mais profundas, mas apesar disso o conhecimento sobre seu hábito alimentar é bastante limitado (OLIVER et al., 1982). Os Phoxocephalidae são geralmente considerados detritívoros (ENEQUIST, 1949; BIERNBAUM, 1979), entretanto, observações sobre o hábito alimentar em algumas espécies desta família, principalmente Heterophoxus videns, indicaram que são carnívoras e que podem mudar o hábito detritívoro para carnívoro de acordo com a disponibilidade de alimento no ambiente (OLIVER et al., 1982).

Dauby et al. (2001) e De Broyer et al. (2003), trabalhando a plataforma Antartica e o mar de Weddell, mostraram que $H$. videns é um predador oportunista da camada 
superficial e subsuperficial do sedimento e que suas atividades de predação geram efeitos significativos na sobrevivência de larvas e juvenis de anelídeos e moluscos. Os exemplares de $H$. videns do presente estudo estão distribuídos nos cinco primeiros centímetros do sedimento, como foi observado em outros trabalhos. Contudo, estudos experimentais na macrofauna deverão ser realizados para avaliar se existe uma influência real da dieta de $H$. videns sobre a densidade de outros grupos da macrofauna. 


\section{CONCLUSÕES}

Os resultados do presente trabalho evidenciaram que o padrão de distribuição dos anfípodes na plataforma continental situada entre São Sebastião e Peruíbe é determinado pela intrusão sazonal da ACAS, a batimetria e a composição sedimentar.

Os resultados apresentados sobre os parâmetros estruturais analisados para a comunidade de anfípodes comprovam que a fauna está distribuída em três áreas da plataforma continental, paralelas à costa: área interna, área intermediária e área externa (profunda).

Num dos extremos desse gradiente situam-se as espécies que predominam em locais rasos e sujeitos à influência das condições físicas da AC e ao revolvimento do fundo, ocasionado por correntes de marés e passagens de frentes frias, estas freqüentes no inverno. Já no outro extremo localizam-se as espécies características de locais profundos e sob influência da ACAS durante todo ano. 0 gradiente ambiental observado é formado principalmente pela variação batimétrica e pelo grau de mistura entre as massas de água, sendo que este último fator está diretamente relacionado com a variação de temperatura.

Uma variação temporal segundo o modo de vida das espécies de anfípodes pode ser observada entre as duas campanhas, sendo a intrusão da ACAS o principal fator desta variação. No inverno os tubícolas de infauna foram dominantes, enquanto que no verão a dominância foi exercida pelos cavadores

A existência de sedimentos predominantemente compostos por areia muito fina e a alta heterogeneidade sedimentar determinam a maior diversidade de habitats e com isso pode-se concluir que ocorre um aumento da diversidade principalmente nas estações ao redor dos $30 \mathrm{~m}$ de profundidade.

A distribuição vertical de anfípodes no sedimento apresentou uma diminuição na densidade e diversidade de espécies entre os estratos, sendo que o estrato de superfície, na interface água-sedimento, apresentou a maior densidade e diversidade quando comparado a outros estratos.

Em relação às espécies a zona costeira foi caracterizada principalmente por espécies, de ciclo curto, no caso Ampelisca paria. Enquanto que na zona profunda (plataforma média) por espécies especializadas e de ciclo de vida longo, como as espécies cavadoras Heterophoxus videns, Pseudoharpinia dentata e Urothoe sp.n. 


\section{CONSIDERAÇÕES FINAIS}

A menor diversidade e densidade observados nos locais situados próximo a Ilha da Moela podem estar associados à descarga de sedimento contaminado derivado de dragagem do canal de Santos.

Informações na literatura considerando o modo de vida e os hábitos alimentares dos anfípodes vêem principalmente do oceano Antártico e de zonas temperadas, em outras regiões do mundo os estudos são escassos e poucas espécies foram estudadas. Como resultado, a classificação utilizada muitas vezes é específica para algumas espécies ou se torna muito ampla quando se têm informações apenas em relação à família ou gênero, ocasionando em erros de classificação. Com base no que foi obtido neste estudo, ficou claro a necessidade de se estudar futuramente os anfípodes presentes na plataforma brasileira e fazer estudos detalhados em laboratório sobre o comportamento desta comunidade tão diversificada em relação ao modo de vida.

É conveniente ressaltar que os dados apresentados neste trabalho mostram a importância de se conhecer os hábitos alimentares das espécies de anfípodes, principalmente daquelas representadas por espécies cavadoras (Famílias Phoxocephalidae e Platyischnopidae). Estas, segundo estudos recentes, desempenham um papel significativo na estruturação da comunidade e, por estarem estreitamente ligadas ao sedimento e serem sensíveis a diferentes tipos de poluentes, podem ser utilizadas como bioindicadoras em trabalhos de monitoramento futuros.

Muitos grupos da macrofauna foram estudados intensamente nos trópicos, como por exemplo, poliquetos e moluscos, pouco esforço foi gasto nos anfípodes. Vale ressaltar ainda que existem poucos pesquisadores no Brasil que estudam a comunidade de anfípodes e que com o passar dos anos contribuíram com informações tanto taxonômicas como ecológicas. Dessa forma, o presente trabalho contribui de forma inédita para os estudos sobre anfípodes na plataforma sudeste do Brasil. Entretanto, ainda há muito a ser feito na região da plataforma estudada para se conhecer a comunidade de anfípodes ai presente. 


\section{REFERÊNCIAS BIBLIOGRÁFICAS}

ABESSA, D.M.S. 2002. Avaliação da qualidade de sedimentos do Sistema Estuarino de Santos, SP, Brasil. Tese de Doutorado, Universidade de São Paulo, Instituto Oceanográfico, $290 \mathrm{p}$.

ABESSA, D.M.S.; SCOTT CARR, R.; RACHID, B.R.F.; SOUSA, E.C.P.M.; HORTELANI, M.A. \& SARKIS, J.E. 2005. Influence of brazilian sewage outfall in the toxicity and contamination of adjacent sediments. Mar. Pollut. Bull., 50: 875-885.

AIDAR, E.; GAETA, S.A.; GIANESELLA-GALVÃO, S.M.F.; KUTNER, M.B.B. \& TEXEIRA, C. 1993. Ecossistema costeiro subtropical: nutrientes dissolvidos, fitoplâncton e clorofila-a e suas relações com as condições oceanográficas na região de Ubatuba, SP. Publção. Eps. Inst. Oceanogr., S. Paulo, 10: 9-43.

ALONSO DE PINA, G.M. 2003. A new species of Phoxocephalidae and some other records of sand-burrowing Amphipoda (Crustacea) from Argentina. J. Nat. Hist., 37 (9): 10291057.

ALONSO DE PINA, G.M. 2008. A catalogue of the Antarctic and sub-Antarctic Phoxocephalidae (Crustacea: Amphipoda: Gammaridea) with taxonomic, distribution and ecological data. Zootaxa, 1752: 1-40.

AYRES, M.; AYRES Jr., M; AYRES, D.L. \& SANTOS, A.A.S. 2007. Bioestat 5.0: Aplicações nas Áreas das Ciências Biológicas e Médicas. 5th Edição. Instituto de Desenvolvimento Sustentável Mamirauá - IDSM/MCT/CNPq, Bélem, Pára.

BACHELET, G.; DAUVIN, J.C. \& J.C. SORBE, J.C. 2003. An updated checklist of marine and brackish water Amphipoda (Crustacea: Peracarida) of the southern Bay of Biscay (NE Atlantic). Cah. Bio. Mar., 44: 121-151.

BARNARD, J.L. 1988. Behavior of gammaridean Amphipoda: Corophium, Grandidierella, Podocerus and Gibberosus (American Megaluropus) in Florida. Crustaceana (Suppl.)13.

BARNARD, J.L. 1991. Amphipodological agreement with Platinick. J. Nat. Hist., 25: 16751676.

BARNARD, J.L. \& KARAMAN, G. 1991. The Families and Genera of Marine Gammaridean Amphipoda (Except Marine Gammaroids), Part 1, 2. Rec. Aust. Mus. (Suppl.), 13: 1-866.

BEARE, D.J. \& MOORE, P.G. 1994. Observations on the biology of rare british marine amphipod: Monoculodes gibbesus (Crustacea: Amphipoda: Oedicerotidae). J. Mar. Bio. Ass. U.K., 74(1): 193-201. 
BEARE, D.J. \& MOORE, P.G. 1998. The life of the offshore Oedicerotidae Westwoodilla caecula e Monoculodes packardi (Crustacea: Amphipoda) from Loch Fyne, Scotland. J. Mar. Bio. Ass. U.K. , 78(3): 835-852.

BEUKEMA, J.J. 1991. Changes in composition of bottom fauna of a tidal-flat area during a period of eutrophication. Mar. Biol., 111: 293-301.

BÍCEGO, M.C.; TANIGUCHI, S.; YOGUI, G.T.; MONTONE, R.C.; SILVA, D.A.M.; LOURENÇO, R.A.; MARTINS, C.C.; SASAKI, S.T.; PELIZZARI, V.H. \& WEBER, R.R. 2006. Assessment of contamination by polychlorinated biphenyls and aliphatic and aromatic hydrocarbons in sediments of the Santos and São Vicente Estuary System, São Paulo, Brazil. Mar. Pol. Bull., 52: 1804-1816.

BÍCEGO, M.C. \& MONTONE, R.C. 2007. Contaminantes Orgânicos. In: PIRES-VANIN, A.M.S. (Org.) A influência do complexo estuarino da Baixada Santista sobre o ecossistema da plataforma adjacente - ECOSAN. Relatório Técnico, 3v: 40-87.

BIERNBAUM, C.K. 1979. Influence in sedimentary factors on the distribution of the benthic amphipods of Fishers Island Sound. J. Exp. Mar. Biol. Ecol., 38: 201-223.

BOUSFIELD, E.L. \& KENDALL, J.A. 1994. The Amphipod Superfamily Dexaminoidea on the north American Pacific coast: Families Atylidae and Dexaminoidae: Systematics and Distributional Ecology. Amphipacifica, 1(3): 3-66.

BRAGA, E.S. \& NIENCHESKI, L.F.H. 2006. Composição das massas de água e seus potenciais produtivos na área entre o Cabo de São Tomé (RJ) e o Chuí (RS). In: ROSSIWONGTSCHOWSKI, C.L.D.B \& MADUREIRA, L.S.P. (eds.) O Ambiente Oceanográfico da Plataforma Continental e do Talude na Região Sudeste-Sul do Brasil. Editora da Universidade de São Paulo, 161-218p.

BRANCO, J.O. \& MORITZ, H.C. Jr. 2001. Alimentação natural do camarão sete-barbas, Xiphopenaeus kroyeri (Hellen) (Crustacea, Decapoda), na Armação do Itapocoroy, Penha, Santa Catarina. Revta. Bras. Zoo.,18(1): 53-61.

BRANCO, J.O. \& LUNARDON-BRANCO, M.J. 2002. Ecologia trófica de Portunus spinimanus Latreille, 1819, na Armação do Itapocoroy, Penha, Santa Catarina. Revta. Bras. Zool., 19(3): 723-729.

BRANDINI, F.P. 2006. Hidrografia e Produção biológica na região sudeste-sul do Brasil no contexto do Programa Revizee. In: ROSSI-WONGTSCHOWSKI, C.L.D.B \& MADUREIRA, 
L.S.P. (eds.) O Ambiente Oceanográfico da Plataforma Continental e do Talude na Região Sudeste-Sul do Brasil. Editora da Universidade de São Paulo, 459-466.

BROOKS, R.A.; PURDY, C.N.; BELL, S.S.; SULAK, K.J. 2006. The benthic community of the eastern US continental shelf: A literature synopsis of benthic faunal resources. Continent. Shelf Res. 26: 804-818.

BUSTAMANTE, A. 2002. Three new species of Microphoxus Barnard, 1960 (Amphipoda, Phoxocephalidae, Metharpiniinae) from the coast of Rio de Janeiro, Brazil. Arq. Mus. Nac. Rio de Janeiro, 60(2): 55-78.

BYRÉN, L.; EJDUNG, G. \& ELMGREN, R. 2006. Uptake of sedimentary organic matter by the deposit-feeding Baltic amphipods Monoporeia affinis and Pontoporeia femorata. Mar. Ecol. Prog. Ser., 313: 135-143.

CALLAWAY, R. 2006. Tube worms promote community change. Mar. Ecol. Prog. Ser., 308: 49-60.

CALIL, M.S. 2005. Distribuição espacial dos crustáceos decápodes e anfípodes de substratos não-consolidados sublitorais da Baía de Sepetiba, Rio de Janeiro, RJ (Brasil). Dissertação de Mestrado, Universidade Federal Fluminense, 145p.

CARTER, J.W. 1982. Natural history observations on the gastropod Shell using amphipod Photis conchicola Alderman, 1936. J. Crus. Bio., 2(3): 328-341.

CAPÍTOLI, R.R. \& BEMVENUTI, C. 2004. Distribuição batimétrica e variações de diversidade dos macroinvertebrados bentônicos da plataforma continental e talude superior no extremo sul do Brasil. Atlântica, Rio Grande, 26 (1): 27-43.

CASADO-MARTINEZ, M.C.; FORJA, J.M. \& DELVALLS, T.A. 2007. Direct comparison of amphipod sensitivities to dredged sediments from Spanish ports. Chemosphere, 68: 677-685.

CASTRO, B.M. de. 1996. Correntes e massas de água da Plataforma Continental norte de São Paulo. Tese de Livre-docência. Instituto Oceanográfico, Universidade de São Paulo, São Paulo, 248 pp.

CASTRO, B.M.; MIRANDA, L.B.; MYAO, S.Y. 1987. Condições hidrográficas na plataforma continental ao largo de Ubatuba: variações sazonais e em média escala. Bolm. Inst. Oceanogr., São Paulo., 35(2): 135-151.

CASTRO, B.M. \& MIRANDA, L.B. 1998. Physical oceanography of the western atlantic continental shelf located between $4^{\circ} \mathrm{N}$ and $34^{\circ} \mathrm{S}$. Coastal segment $(4, \mathrm{~W})$. In: 
ROBINSON, A.R. \& BRINK, K.H. (Eds.) The Sea, V.11, John Willey \& Sons. Inc. Chapter 8, 209-251p.

CASTRO, B.M.;LORENZZETTI, J.A.; SILVEIRA, I.C.A.; MIRANDA, L.B. 2006. Estrutura termoclina e circulação na região entre o Cabo de São Tomé (R.J.) e o Chuí (R.S.). In: ROSSI-WONGTSCHOWSKI, C.L.D.B \& MADUREIRA, L.S.P. (eds.) 0 Ambiente Oceanográfico da Plataforma Continental e do Talude na Região Sudeste-Sul do Brasil. Editora da Universidade de São Paulo, 11-120p.

CASTRO, B.M.; MIRANDA, L.B.; SILVA, L.S.; FONTES, R.F.C.; PEREIRA, A.F.; COELHO, A.L. 2008. Processos Físicos: Hidrografia, Circulação e Transporte. In: PIRES-VANIN, A.M.S. (Org.). Oceanografia de um Ecossistema Subtropical: Plataforma de São Sebastião, SP. São Paulo: Editora da Universidade de São Paulo, 59-121p.

CESAR, A.; CHOUERI, R.B.; MORALES-CASEllES, C.; PEREIRA, C.D.S.; SANTOS, A.R.; ABESSA, D.M.S. \& DELVALLS, T.A. 2007. Comparative sediment quality assesment in different littoral ecosystems from Spain (Gulf of Cadiz) and Brazil (Santos and São Vicente estuarine system). Env. Int., 33: 429-435.

CHIESA, I.L. \& ALONSO, G.M. 2007. Biodiversity of the Gammaridea and Corophiidea (Crustacea: Amphipoda) from the Beagle Channel and the Straits of Magellan: a preliminary comparison between their faunas. Rev. Biol.Trop (Int. J. Trop. Biol.)., 55 (Suppl. 1): 103-112.

CHOUERI, R.B.; CESAR, A.; ABESSA, D.M.S.; TORRES, R.J.; MORAIS, R.D.; RIBA, I.; PEREIRA, C.D.S.; NASCIMENTO, M.R.L.; MOZETO, A.A.\& DELVALLS, T.A. 2009Development of site sediment quality guidelines for North and South Atlantic littoral zones: Comparison against national an international sediment quality benchmarks. J. Hazard. Mater., In Press.

CLARKE, K.R. 1993. Non-parametric multivariate analysis of changes in community structure. Austr. J. Ecol., 18: 117-143.

CLARKE, K.R. \& WARWICK, R.M. 1994. Change in marine communities: An Approach to Statistical Analysis and Interpretation. Plymouth Marine Laboratory, Plymouth, 144p.

CLARKE, K.R. \& WARWICK, R.M. 2001. Change in marine communities: An Approach to Statistical Analysis and Interpretation, 2nd edition. Plymouth Marine Laboratory, Plymouth, 
CONLAN, K.E. 1994. Amphipod crustaceans and environmental disturbance: a review. J. Nat. Hist., 28: 519-554.

CONTI, L.A. 2004. Geomorfologia da plataforma continental do Estado de São Paulo. Tese de Doutorado, Instituto Oceanográfico, Universidade de São Paulo, São Paulo, 210pp.

CORBISIER, T.N.; PETTI, M.A.V.; ARGEIRO, M.C.C.; YAGINUMA, L.E. \& KLEIN, A. 2008. Meiofauna. IN: PIRES-VANIN, A.M.S (Org.) A influência do complexo estuarino da Baixada Santista sobre o ecossistema da plataforma adjacente - ECOSAN. Relatório Técnico, 4v: 495-522.

CÔRREA, I.C.S. \& VILLWOCK, J.A. 1996. Continental shelf and coastal plain sediments of the southeast and south coast of Brazil. In: Martins, L.R. \& I.C.S. Côrrea (eds.). Morphology and sedimentology of the southeast Atlantic coastal zone and continental shelf from Cabo Frio (Brazil) to Peninsula Valdis (Argentina). Pp. 41-54.

CORREIA, A.D.; COSTA, M.H.; RYAN, K.P. \& NOTT, J.A. 2002. Studies on biomarkers of copper exposure and toxicity in the marine amphipods Gammarus locusta (Crustacea): I. Copper-containing granules within the mid gut gland. J. Mar. Biol. Ass. U.K., 82: 827-834.

CUNHA, M.R.; SORBE, J.C. \& MOREIRA, M.H. 1999. Spatial and seasonal changes of branckish peracaridan assemblages and their relation to some environmental variables in two tidal channels of the Rio de Aveiro (NW Portugal). Mar Ecol. Prog. Ser., 190: 69-87.

DAUBY, P.; SCAILTEUR, Y. \& DE BROYER, C. 2001. Trophic diversity within the eastern Weddel Sea amphipod community. Hydrobiologia, 443: 69-86.

DAUVIN, J.C. 1998. The fine sand Abra alba community of the Bay of Morlaix twenty years after the Amoco Cadiz oil spill. Mar. Pollut. Bull., 36 : 669-676.

DAUVIN, J.C. 2000. The muddy fine sand Abra alba - Melinna palmata community of the Bay of Morlaix twenty years after the Amoco Cadiz oil spill. Mar. Pollut. Bull., 40 : 528536.

DAUVIN, J.C. ; BELLAN-SANTINI, D. \& BELLAN, G. 1993. Les genres Ophelia et Ampelisca de la région de Roscoff : exemples dállotopie et de syntopie dans les communautés marines de substrat meuble. Cah. Biol. Mar., 34: 1-15.

DAUVIN, JC. \& T. RUELLET 2007. Polychaeta/amphipod ratio revisited. Mar. Pollut. Bull., 55: 215-224. 
DAUWE, B.; HERMAN, P.M.J. \& HEIP, C.H.R. 1998. Community structure and bioturbation potential of macrofauna at four North Sea stations with contrasting food supply. Mar. Ecol. Prog. Ser., 173: 67-83.

DE BROYER, C. \& RAUSCHERT, M. 1999. Faunal diversity of the benthic amphipods (Crustacea) of the Magellan region as compared to the Antarctic (preliminary results). Sci. Mar., 63 (Suppl. 1): 281-293.

DE BROYER, C; CHAPELLE, G.; DUCHESNE, P.-A.; MUNN, F; NYSSEN, Y.; SCAILTEUR, F.; VAN ROOZENDAEL \& DAUBY, P. 2003. Structural and ecofunctional biodiversity of the amphipod crustacean benthic taxocoenoses in the Southern Ocean. In: Scientific Support Plan for a Sustainable Development Policy SPSD 1: Belgian Scientific Research Programme on the Antarctic, Phase 4 (1997-2001). Scientific Results, 1: Marine Biota and Global Change, pp 1-58.

ENEQUIST, P. 1949. Studies o the soft-bottom amphipods of the Skageral. Zool. Bidr. Uppsala, 28: 297-492.

FERREIRA, J.A. 2008. Estudo das associações de anelídeos Polychaeta da Baía de Santos e Plataforma Continental Adjacente (SP, Brasil) e suas inter-relações com parâmetros físicos e geoquímicos estruturadores. Tese de Doutorado, Instituto Oceanográfico, Universidade de São Paulo, 205pp.

FLACH, E. \& HEIP, C. 1996. Vertical distribution of macrozoobenthos within the sediment on the continental slope of the Cogan Spur are (NE Atlantic). Mar. Ecol. Prog. Ser., 141: $55-66$.

FLYNN, M.N.; VALÉRIO-BERARDO, M.T.; WAKABARA, Y. \& MIYAGI, V.K. 1999. Preliminary study of the spatial distribution of the benthic macrofauna of São Sebastião channel, Southeastern Brazil. Oceánides, 14(2): 97-111.

FOLK, R. L. \& WARD, W.C. 1957. Brazos River Bay: a study of the significance of grain size parameters. J. Sedim. Petrol., 27: 3-26.

FURTADO, V.V. \& MAHIQUES, M.M. 1990. Distribuição de sedimentos em regiões costeiras e plataforma continental norte do Estado de São Paulo. In: Simpósio de Ecossistemas da Costa Sul e Sudeste Brasileira, 2. Publ. Ac. Ciênc. Estação S. Paulo, 71(1): 20-29.

GALLERANI, G. 1997. Análise Qualitativa dos Amphipoda da Bacia de Campos, RJ, Brasil. Dissertação de Mestrado, Universidade de São Paulo, Instituto Oceanográfico, 128p. 
GRANT, J. 1981a. Factors affecting the occurrence of intertidal amphipods in reducing sediments. J. Exp. Mar. Biol. Ecol., 49: 203-216.

GRANT, J. 1981b. Dynamics of competition among estuarine sand-burrowing amphipods. J. Exp. Mar. Biol. Ecol., 49: 255-265.

GRAY, J.S. 2002. Species richness of marine soft sediments. Mar. Ecol. Prog. Ser., 244: 285297.

GROSS, M.G. 1971. Carbon determination. In: Carver R.E. (Ed.), Procedures in Sedimentary Petrology. Wiley-Insterscience, New York,, pp: 573-596.

HARGRAVE, B.T. 1970. The effect of a deposit-feeding amphipod on the metabolism of benthic microflora. Limnol. Oceanogr., 15 (1): 21-30.

HEUVEL-GREVE, M.; POSTMA, J.; JOL, J.; KOOMAN, H.; DUBBELDAM, M.; SCHIPPER, C.; KATER, B. 2007. A chronic bioassay with the estuarine amphipod Corophium volutator: Test method description and confounding factors. Chemosphere, 66: 13011309.

HOEY, G.V.; DEGRAER, S.; VINCX, M. 2004. Macrobenthic community structure of softbottom sediments at the Belgian Continental Shelf. Estuar. Coast. Shelf Sci., 59: 599613.

JACOBI, C.M. 1987. Spatial and temporal distribution of Amphipod associated with mussel beds from the Bay of Santos (Brazil). Mar. Ecol. Progr. Ser., 35: 51-58.

JUST, J. 1988. Siphonoecetinae (Corophiidae) VI: a survey of phylogeny, distribution and biology. Crustaceana (Sppl.) 13: 193-208.

KOWSMANN, R.O.; COSTA, M.P.A. 1979. Quaternary sedimentation of the Brazilian continental margin and adjacent oceanic areas (final report). REMAC Project Series, no 8. Rio de Janeiro, PETROBRÁS, 55 pp.

LANA, P.C.; CAMARGO, M.G.; BROGIM, R.A.; ISAAC, V.J. 1996. O bentos da costa brasileira Avaliação crítica e Levantamento Bibliográfico (1858-1996). Avaliação do potencial sustentável de Recursos Vivos na Zona Econômica Exclusiva - REVIZEE. 432p.; mapas.

LONGHURST, A.R. \& PAULY, D. 1987. Ecology of tropical oceans. San Diego, Academic, 407pp.

LOWRY, J.K. \& SPRINGTHORPE, R.T. 2007. A revision of the tropical/temperate amphipod genus Dulichiella Stout, 1912, and the description of a new Atlantic genus Verdeia gen. nov. (Crustacea: Amphipoda: Melitidae). Zootaxa, 1424: 1-62. 
LU, L.; WU, R.S.S. 2006. A field experimental study on recolonization and succession of macrobenthic infauna in defaunated sediment contaminated with petroleum hydrocarbons. Estuar. Coast. Shelf Sci., 68: 627-634.

MAHIQUES, M.M. 1998. Características da matéria orgânica sedimentar da plataforma continental interna e média entre a Baía de Guanabara (RJ) e São Francisco do Sul (SC). Tese de Livre-Docência. Universidade de São Paulo, Instituto Oceanográfico. 86p.

MAHIQUES, M.M.; MISHIMA, Y.; RODRIGUES, M. 1999. Characteristics of the sedimentary organic matter on the inner and middle continental shelf between Guanabara Bay and São Francisco do Sul, southeastern Brazilian margin. Continent. Shelf. Res., 19: 775798.

MAHIQUES, M.M.; TESSLER, M.G.; CIOTTI, A.M.; SILVEIRA, I.C.A.; SOUZA, S.H.M.; FIGUEIRA, R.C.L.; TASSINARI, C.C.G.; FURTADO, V.V. \& PASSOS, R.F. 2004. Hydrodynamically driven patterns of recent sedimentation in the shelf and upper slope off Southeast Brazil. Continent. Shelf Res., 24: 1685-1697.

MARQUES, J.C. \& BELLAN-SANTINI, D. 1993. Biodiversity in the ecosystem of the Portuguese continental shelf: distributional ecology and the role of benthic amphipods. Mar. Biol., 115: 555-564.

MARTINS, C.C.; FERREIRA, J.A.; TANIGUCHI, S.; MAHIQUES, M.M.; BÍCEGO, M.C. \& MONTONE, R.C. 2008. Spatial distribution of sedimentary linear alkybenzenes and faecal steroids of Santos Bay and adjoining continental shelf, SW Atlantic, Brazil: Origin and fate of sewage contamination in the shallow coastal environment. Mar. Pollut. Bull., 56(8): 1353-1376

MARTINS, L.R.; CORREAA, I.C.S. (Eds.). 1996. Atlas Morphology and Sedimentology of the Southwest Atlantic Coastal Zone and Continental Shelf from Cabo Frio (Brazil) to Peninsula Valdés (Argentina). Porto Alegre, UFRGS, 4 pp., 20 maps.

MASSAMBA N' SIALA, G. ; GRANDI, V.; IOTTI, M.; MONTANARI, G.; PREVEDELLI, D.; SIMONINI, R. 2008. Responses of a Northern Adriatic Ampelisca-Corbula community to seasonality and short-term hydrological changes in the Po river. Mar. Environ. Res., 66: 466-476.

MELO, S.L.R., NIPPER, M. 2007. Sediment toxicity tests using the burrowing amphipod Tiburonella viscana (Amphipoda: Platyischnopidae). Ecotox. Envir. Saf., 66: 412-420. 
MENGHINI, R.P. 2004. Ecologia de Manguezais: Grau de perturbação e processos regenerativos em bosques de mangue da Ilha Barnabé, Baixada Santista, São Paulo, Brasil. Dissertação de Mestrado. Universidade de São Paulo, Instuto Oceanográfico, $115 p$.

MIYAGI, V.K. 2000. Gammaridea (Crustacea-Amphipoda) do Talude e Plataforma Continental Coletados entre as Latitudes $21^{\circ} 37^{\prime} \mathrm{S}$ e $30^{\circ} 43^{\prime} \mathrm{S}$. Dissertação de Mestrado. Universidade de São Paulo, Instituto Oceanográfico, 62p.

MOORE, P.G. \& CAMERON, K.S. 1999. A note on a hitherto unreported association between Photis longicaudata (Crustacea: Amphipoda) and Cerianthus lloydi (Anthozoa: Hexacorallia). J. Mar. Ass. U.K., 79: 369-370.

MOREIRA, J.; GESTOSO, L. \& TRONCOSO, J.S. 2008. Diversity and temporal variation of peracarid fauna (Crustacea: Peracarida) in the shallow subtidal of a sandy beach: Playa América (Galicia, NW Spain). Mar. Ecol., 29 (1): 12-18.

MUCHA, A.P. \& COSTA, M.H. 1999. Macrozoobenthic structure in two Portuguese estuaries: relationship with organic enrichment and nutrient gradients. Acta Oecologica, 20: 363-376.

MUCHA, A.P.; VASCONSELOS, M.T.S.D.; BORDALO, A.A. 2004. Vertical distribution of the macrobenthic community and its relationships to trace metals and natural sediment characteristics in the lower Douro estuary, Portugal. Estuar., Coast, Shelf Sci., 59: 663673.

MUNIZ, P. \& PIRES-VANIN, A.M.S. 2000. Polychaetes associations in a subtropical environment (the São Sebastião Channel, SP, Brazil): a structural analysis. Mar. Ecol., 21(2): 145-160.

MYERS, A.A. \& LOWRY, J.K. 2003. A Phylogeny and a new Classification of the Corophiidea Leach, 1814 (Amphipoda). J. Crust. Bio., 23 (2): 443-485.

OLAFSSON, E. \& ELMGREN, R. 1991. Effects of biological disturbance by benthic amphipods Monoporeia affinis on meiobenthic community structure: a laboratory approach. Mar. Ecol. Progr. Ser., 74: 99-107.

OLIVER, J.S.; J.M. OAKDEN \& P.N. SLATTERY 1982. Phoxocephalid amphipod crustaceans as predators on larvae and juveniles in marine soft-bottom communities. Mar. Ecol. Prog. Ser., 7: 179-184. 
OLIVER, J.S. \& SLATTERY, P.N. 1985. Destruction and opportunity on the sea floor: Effects of gray whale feeding. Ecology, 66 (6): 1965-1975.

PAIVA, P.C. 1990. Padrões de distribuição e estrutura trófica dos anelídeos poliquetos da plataforma continental do litoral norte do Estado de São Paulo. Dissertação de Mestrado. Universidade de São Paulo, Instituto Oceanográfico, 146p.

PAIVA, P.C. 1993a. Trophic structure of a shelf polychaeta taxocoenosis in southern Brazil. Cah. Biol. Mar., 35(1): 39-55.

PAIVA, P.C. 1993b. Anelídeos políquetos da plataforma continental norte do Estado de São Paulo: I. Padrões de densidade e diversidade específicas. Bolm. Inst. Oceanogr. S. Paulo, 41(1-2): 69-80.

PALMA, A.T. \& OJEDA, E.P. 2002. Abundance, distribution and feeding patterns of a temperate reef fish in subtidal environments of the Chilean coast: the importance of understory algal turf. Revta. Chil. Hist. Natur., 75: 189-200.

PENTEADO, A.R. 1965. As bases geológicas. In: Azevedo, A. (Ed.) A Baixada Santista: aspectos geográficos. Editora da universidade de São Paulo, SP. v.1.

PIELOU, E.C. 1975. Ecological Diversity. J.W. Ley Ed. New York. 165p.

PIRES-VANIN, A.M.S. 1992. Structure and dynamics of benthic megafauna on the continental shelf offshore of Ubatuba, Southeastern Brazil. Mar. Ecol. Prog. Ser., 86: 63-76.

PIRES-VANIN, A.M.S. 1993. A macrofauna bêntica da Plataforma Continental ao Largo de Ubatuba São Paulo, Brasil. Publção esp. Inst. Oceanogra., S. Paulo, 10: 137-158.

PIRES-VANIN, A.M.S. 2005. A influência do complexo estuarino da Baixada Santista sobre o ecossistema da plataforma adjacente - ECOSAN. Relatório Técnico, 1v: 112pp.

PIRES-VANIN, A.M.S. 2008. Megafauna e Macrofauna. In: PIRES-VANIN, A.M.S. (Org.) Oceanografia de um ecossistema subtropical: plataforma de São Sebastião, SP. São Paulo: EDUSP - Editora da Universidade de São Paulo, 311-350.

PIRES-VANIN, A.M.S.; CORBISIER, T.N.; ARASAKI, E. \& MOELLMANN, A.M. 1997. Composição e distribuição espaço-temporal da fauna bêntica no Canal de São Sebastião. Relátorio Técnico do Instituto Oceanográfico, São Paulo, n. 41: 29-46.

PIRES-VANIN, A.M.S.; BROMBERG, S.; SILVA, D.A.M. 2006a. A contaminação orgânica é fator de impacto para a comunidade de crustáceos do Canal de São Sebastião, SP. In: 
IV Congresso Brasileiro sobre Crustáceos, 2006, Guarapari. Resumo do IV Congresso Brasileiro sobre Crustáceos.

PIRES-VANIN, A.M.S.; BROMBERG, S. \& SILVA, D.A.M. 2006b. Avaliação da fauna de Polychaeta em áreas impactadas por contaminação orgânica no Canal de São Sebastião, SP. In: $1^{\circ}$ Simpósio Latino-Americano de Polychaeta, 2006, São Sebastião. Resumos do $1^{\circ}$ Simpósio Latino-Americano de Polychaeta, p 62.

PIRES-VANIN, A.M.S.; BROMBERG, S.; FERREIRA, J.A.; RODRIGUES, C.W. \& SHIMABUKURU, M. 2007. Bentos: Megafauna e Macrofauna. In: PIRES-VANIN, A.M.S. (Org.) A influência do complexo estuarino da Baixada Santista sobre o ecossistema da plataforma adjacente - ECOSAN. Relatório Técnico, 3v: 358-395.

PIRES-VANIN, A.M.S.; BROMBERG, S.; FERREIRA, J.A.; RODRIGUES, C.W.; SHIMABUKURU, M. 2008a. Bentos. Megafauna. Plataforma continental adjacente situada entre São Sebastião e Peruíbe. IN: PIRES-VANIN, A.M.S. (Org.) A influência do complexo estuarino da Baixada Santista sobre o ecossistema da plataforma adjacente - ECOSAN. Relatório Técnico, 4v: 462-478.

PIRES-VANIN, A.M.S.; CASTRO, B.M.; MIRANDA, L.B.; DIAS, J.F.; BÍCEGO, M.C.; KATSURAGAWA, M.; LOPES, R.; GIANESELLA, S.M.F. \& CORBISIER, T.N. 2008b. Síntese dos resultados e conclusões. In: PIRES-VANIN, A.M.S. (Org.) A influência do complexo estuarino da Baixada Santista sobre o ecossistema da plataforma adjacente - ECOSAN. Relatório Técnico, 4v: 627-643.

POSEY, M.H. 1987. Influence of relative mobilities on the composition of benthic communities. Mar. Ecol. Prog. Ser., 39: 99-104.

POSEY, M.H.; ALPHIN, T.D.; CAHOON, L.B.; LINDQUIST, D.G.; MALLIN, M.A.; NEVERS, M.B. 2002. Top-down versus Bottom-up limitation in benthic infaunal communities: Direct and Indirect effects. Estuarines, 25(5): 999-1014.

QUINTANA, C.O. 2007. Relações entre as comunidades bênticas e a matéria orgânica sedimentar: respostas à qualidade dos recursos alimentares e influência na diagênese recente. Tese de Doutorado, Instituto Oceanográfico, Universidade de São Paulo, São Paulo, 205pp.

REISS, H. \& KRÖNCKE, J. 2005. Seasonal variability of infaunal community structures in three areas of the North Sea under different environmental conditions. Estuar. Coast.. Shelf Sci., 65: 253-274. 
ROCHA, J.; MILLIMAN, J.D.; SANTANA, C.I.; VICALVI, M.A. 1975. Southern Brazil. Contribution to Sedimentology. V. 4: Upper continental margin sedimentation off Brazil. Stuttgart, p 117-150.

RODRIGUES, J.C. 1965. As bases geológicas. In: Azevedo, A. (Ed.). A Baixada Santista: aspectos geográficos. Editora da Universidade de São Paulo, SP. v.1

SANTOS, E. 1965. Características climáticas. Baixada Santista: aspectos geográficos. In: Departamento de Geografia da Faculdade de Filosofia e Letras da Universidade de São Paulo, v.1.

SANTOS, K.C. 1999. Aspectos Ecológicos de Peracarida (Crustacea), com ênfase na comunidade de Amphipoda, na plataforma continental interna de São Sebastião, Litoral Norte do Estado de São Paulo - Brasil (Verão - 1994). Dissertação de mestrado, Instituto Oceanográfico, Universidade de São Paulo, 143pp.

SANTOS, K.C \& PIRES-VANIN, A.M.S. 2000. Ecology and distribution of Peracarida (Crustacea) in the continental shelf of São Sebastião (SP), with emphasis on the amphipod community. Nauplius, 8(1): 35-53.

SCHAEFFER - NOVELLI, Y. 1986. Rompimento de oleoduto. Avaliação de impacto ambiental no Canal de Bertioga - SP. Perícia de Juízo. Ministério Público do Estado de São Paulo.

SCHAFFNER, L.C. \& BOESCH, D.F. 1982. Spatial and Temporal Resource use by dominant benthic amphipoda (Ampeliscidae and Corophiidae) on the Middle Atlantic bight outer continental shelf. Mar. Ecol. Prog. Ser., 9: 231-243.

SEREJO, C.S.; LICÍNIO, M.V.S. 2002. The genus Ampithoe (Crustacea, Amphipoda, Ampithoidae) from the Brazilian coast. Arq. Mus. Nac., Brasil, RJ., 60: 41-50.

SEREJO, C. S.; WAKABARA, Y.; VALÉRIO-BERARDO, M.T. 2000. Taxonomy and geographic distribution of Ampelisca (Amphipoda: Gammaridea) from the Brazilian Coast. Pol. Arch. Hydrobiol.,47 (3-4): 495-510.

SHANNON, C.E. \& WEAVER, W. 1963. The mathematical theory of communication. Urbana, University of Illinois Press, 173pp.

SOLA, M.C.R. \& P.C. PAIVA 2001. Variação temporal da macrofauna bentônica sublitoral da praia da Urca (RJ) após a ocorrência de ressacas. Ver. Bra. Ocea., 49(1/20): 137-142.

SOUZA FILHO, J.F. 2007. Amphipoda (Crustacea: Peracarida) da Plataforma Continental e Bancos Oceânicos da Região Nordeste do Brasil: Programa REVIZEE III e IV. 
Dissertação de Mestrado, Centro de Tecnologia e Geociências, Universidade Federal de Pernambuco, 85pp.

SUGUIO, T. 1973. Introdução à sedimentologia. São Paulo, Edgard Blucher, EDUSP. 317p.

SUMIDA, P.; PIRES-VANIN, A.M.S. 1997. Benthic associations of the shelfbreak and upper slope off Ubatuba - SP, south-eastern Brazil. Estuar. Coast.. Shelf Sci.,44: 779-784.

TESSLER, M.G. \& GOYA, S.C. 2007. Granulometria e metais. IN: PIRES-VANIN, A.M.S. (Org.) A influência do complexo estuarino da Baixada Santista sobre o ecossistema da plataforma adjacente - ECOSAN. Relatório Técnico, 3v: 36-39.

THIEL, M. 1997. Epibenthic predation in marine soft-bottoms: being small and how to get away with it. Hydrobiologia, 355: 11-19.

THIEL, M. 1999a. Duration of extended parental care in marine amphipods. J. Crust. Biol., 19 (1): 60-71.

THIEL, M. 1999b. Extended parental care in marine amphipods II. Maternal protection of juveniles from predation. J. Exp. Mar. Biol. Ecol.,234: 235-253.

THIEL, M. 2000. Extended parental care behavior in crustaceans - A comparative over review. Crust. Issues, 12: 211-226. In: Klein, J.C. von Vaupel \& F.R. Schram (eds.), The Biodiversity Crisis and Crustacea: Proccedings of the Fourth International Crustacean Congress, Amsterdam, Netherlands, 20-24 July 1998, vol. 2. Balkema, Brookfield, VT.

THIEL, M.; SAMPSON, S. \& WATLING, L. 1997. Extended parental care in two endobenthic amphipods. J. Nat. Hist., 31: 713-725.

THIEL, M.; GONZALEZ, E.R.; BALANDA, M.J.; HAYE, P.; HEARD, R. \& WATLING, L. 2003. Diversity of Chilean peracarids (Crustacea: Malacostraca). Constr. Study East Pac. Crust., 2:1-13.

THOMAS, J.D. 1993. Biological monitoring and tropical biodiversity in marine environments: a critique with recommendations, and comments on the use of amphipods as bioindicators. J. Nat. Hist., 27: 795-806.

THOMAS, J.D. \& BARNARD, J.L. 1983. The Platyischnopidae of the Americas (Crustacea: Amphipoda). Smithson. Contrib. Zool., 375: 1-33

VADER, W. 1983. Associations between amphipods (Crustacea: Amphipoda) and sea anemones (Anthozoa: Actiniaria). In: Papers from the Conference on the biology and evolution of Crustacea, Sydney, 1980 (Ed. J.K. Lowry), pp. 141-153. The Trustees of the Australian Museum. Aust. Mus. Mem, 18. 
VALÉRIO-BERARDO, M.T. 1992. Composição e distribuição da fauna de Amphipoda de fundos não consolidados da região de Ubatuba, (SP-Brasil). Tese de Doutorado. Universidade de São Paulo, Instituto Oceanográfico. 148p.

VALÉRIO-BERARO, M.T.; FLYNN, M.N. \& WAKABARA, Y. 2000a. Structure and dynamics of a shelf amphipod taxocoenosis in southeastern Brazil. Bull. Mar. Sci., 66(1): 59-72.

VALÉRIO-BERARDO, M.T.; FLYNN, M.N. \& WAKABARA, Y. 2000b. Patterns of distribution based on the life style of amphipods from the sub-tropical shelf of Ubatuba, southeastern Brazil. Pol. Arch. Hydrobiol., 47(3-4): 533-539.

VALÉRIO-BERARDO, M.T.; FLYNN, M.N. \& WAKABARA, Y. 2000c. Density and diversity patterns of a shelf amphipoda taxocoenosis in Ubatuba, southeastern Brazil. Oceánides, 15(2): 117-127.

VALÉRIO-BERARDO, M.T. \& MYAGI, V. K. 2000. Corophiidae (Crustacea, Amphipoda) da costa brasileira. Rev. Bras. Zool., 17(2): 481-504.

VALÉRIO-BERARDO, M.T.; SEREJO, C.S.; WAKABARA, Y. 2005. Description of the new species of Ampelisca (Crustacea, Amphipoda, Ampeliscidae) from Southwestern Atlantic, with a key for Brazilian species of the genus. Nauplius, São Paulo, 13 (2): 115126.

VALÉRIO-BERARDO, M.T. \& WAKABARA, Y. 2006. Ampeliscidae from the Brazilian coast. Record of Ampelisca burkey Barnard \& Thomas, 1989 and descriptions of two new species of Ampelisca (Crustacea, Amphipoda). Zootaxa, 1286: 1-14.

VALÉRIO-BERARDO, M.T.; DE SOUZA, A.M.T. \& RODRIGUES, C.W. 2007. A new species of Cheirophotis (Crustacea: Amphipoda: Corophiidae; Protomedeiinae) from the coast of Southeastern Brazil, with a key to species in the genus. Zootaxa, 1646: 41-46.

VALÉRIO-BERARDO, M.T.; DE SOUZA, A.M.T \& RODRIGUES, C.W. 2008. Description of two new species of Ischyroceridae (Crustacea: Amphipoda) from the coast of Southeastern Brazil. Zootaxa, 1857: 55-65.

VENTURINI, N. 2007. Influência da quantidade e qualidade da matéria orgânica sedimentar na estrutura e distribuição vertical e horizontal das comunidades bentônicas na plataforma de São Sebastião, São Paulo, Brasil. Tese de Doutorado, Instituto Oceanográfico, Universidade de São Paulo, São Paulo, 210pp.

VIGANO, L.; FARKAS, A.; GUZZELlA, L.; ROSCIOLI, C.; ERRATICO, C. 2007. The accumulation levels of PAHs, PCBs and DDTs are related in an inverse way to the size 
of a benthic amphipod (Echinogammarus stammeri Karaman) in the River Po. Sci. Total Environ. 373(1): 131-145.

WAKABARA, Y. 1969. Sobre alguns Gammaridae (Crustacea: Amphipoda) na região de Ubatuba. Dissertação de Mestrado. Universidade de São Paulo, Instituto oceanográfico, 52pp.

WAKABARA, Y. 1972. Espécies da Família Gammaridae (Crustacea-Amphipoda), entre as latitudes $03^{\circ} 23^{\prime}$ e $38^{\circ} 05^{\prime \prime} \mathrm{S}$ do Atlântico Ocidental. Tese de Doutorado. Universidade de São Paulo, Instituto Oceanográfico, 87pp.

WAKABARA, Y.; KAWAKAMI DE RESENDE, E. \& TARARAM, A. S. 1982. Amphipods as one of the main food components of three Pleuronectiformes from the continental shelf of south Brazil and north Uruguay. Mar. Biol., 68(1): 67-70.

WAKABARA, Y.; TARARAM, A.S.; VALÉRIO-BERARDO. M.T. \& OGIHARA, R.M. 1990. Records of amphipod collected during I and III Brazilian Antarctic Expeditons. Relat. Int. Inst. Oceanogr. Universidade de São Paulo, 30: 1-9.

WAKABARA, Y.; TARARAM, A.S.; VALÉRIO-BERARDO, M.T.; DULEBA, W. \& LEITE, F.P.P. 1991. Gammaridean and caprellidean fauna from Brazil. Hydrobiologia, 223: 69-77.

WAKABARA, Y. \& SEREJO, C.S. 1998. Malacostraca - Peracarida. Amphipoda. Gammaridea and Caprellidea. In: YOUNG, P.S. (ed.). Catalogue of Crustacea of Brazil (Série livros: n.6). Rio de Janeiro: Museu Nacional: 561-594.

WETZEL, M.A.; LEUCHS, H. \& KOOP, J.H.E. 2005. Preservation effects on wet weight, dry weight, and ash-free dry weight biomass estimates of four common estuarine macroinvertebrates: no difference between ethanol and formalin. Helgol. Mar. Res., 59: 206213.

WIEKING, G.; KRÖNCKE, I. 2003. Macrofauna communities of the Dogger Bank (Central North Sea) in the late 1990s: spatial distribution, species composition and trophic structure. Helgol. Mar. Res., 57: 34-46.

WILSON, W.H. 1991. Competition and predation in marine soft-sediment communities. Annu. Ver. Ecol. Syst., 21: 221-241.

YESAKI, M. 1974. Os recursos de peixes de arrasto ao longo da costa do Brasil. PDP/SUDEPE. Doc. Tec. 22pp. 
YU, O.H.; SOH, H.Y. \& SUH, H-L. 2002. Life history and reproduction of Synchelidium lenorostralum (amphipoda, Oedicerotidae) in a temperate sandy chore, Southern Korea. J. Crus. Biol., 22(1): 126-134.

YU, H.O.; SUH, H.L.\& SHIRAYAMA, Y. 2003. Feeding ecology of three amphipod species Synchelidium lenorostralum, S. trioostegitum and Gitanopsis japonica in the surf zone of a sandy shore. Mar. Ecol. Prog. Ser., 258: 189-199.

ZEMBRUSKI, S.G. 1979. Geomorfologia da margem continental sul brasileira e das bacias oceânicas adjacentes. PETROBRÁS - DNPM - CPRM - DHN- CNPq. Reconhecimento Global da Margem Continental Brasileira. Projeto REMAC> PETREBRÁS CENPES < Rio de Janeiro. Vol 7. - p. 129-177 
ANEXOS 
Anexo I - Densidade das espécies encontradas no Estrato de Superfície (S) no inverno (agosto e setembro de 2005) nas estações amostradas na plataforma continental entre São Sebastião e Peruíbe, SP.

\begin{tabular}{|c|c|c|c|c|c|c|c|c|c|c|c|}
\hline Espécies & $1 S$ & $2 S$ & $3 \mathrm{~S}$ & $4 \mathrm{~S}$ & $5 S$ & $6 S$ & $7 \mathrm{~s}$ & $8 \mathrm{~S}$ & $9 \mathrm{~S}$ & $10 \mathrm{~S}$ & $11 \mathrm{~S}$ \\
\hline Ampelisca sp.1 & 0 & 0,5 & 0 & 0 & 0 & 0 & 0 & 0 & 0 & 0 & 0 \\
\hline Ampelisca sp.2 & 0 & 0 & 7 & 0 & 0 & 0 & 0 & 0 & 0 & 0 & 0 \\
\hline Ampelisca brevisimulata & 0 & 18,5 & 0 & 0 & 0 & 1,5 & 0 & 0 & 0 & 0 & 1,5 \\
\hline Ampelisca cristata & 0 & 0 & 1 & 0 & 0 & 0 & 0 & 0 & 0 & 0 & 0 \\
\hline Ampelisca moreirai & 0 & 1 & 5 & 0 & 0 & 0 & 0 & 1,5 & 0 & 0 & 1,5 \\
\hline Ampelisca paria & 25,5 & 0 & 0 & 0 & 6 & 9,5 & 38 & 8 & 7,5 & 3,5 & 0 \\
\hline Ampelisca pugetica & 0 & 1 & 0,5 & 0,5 & 0 & 0,5 & 0 & 0 & 0 & 0 & 1 \\
\hline Ampelisca rodriguesi & 0 & 0 & 0 & 10 & 0 & 0 & 0 & 0 & 0 & 0 & 3 \\
\hline Ampelisca romigi & 0 & 1 & 0 & 11,5 & 0 & 0 & 0 & 0 & 0 & 0 & 1 \\
\hline Ampelisca subtropicalis & 0 & 0 & 0,5 & 0 & 0 & 0 & 0 & 0 & 0 & 0 & 0 \\
\hline Gitanopsis sp. & 0 & 0 & 0,5 & 0,5 & 0 & 0 & 0 & 0 & 0 & 0 & 0 \\
\hline Amphitoe ramondi & 0 & 0 & 0 & 0 & 0 & 0 & 0 & 0 & 0 & 0 & 0 \\
\hline Lembos sp. & 0 & 0 & 0 & 1 & 0 & 0 & 0 & 1,5 & 0 & 0 & 0 \\
\hline Cheirophotis megacheles & 0 & 1 & 0 & 0 & 0 & 0 & 0 & 0 & 0 & 0 & 0 \\
\hline Cheirophotis neotropicalis & 0 & 0,5 & 0 & 0 & 0 & 0,5 & 0 & 0,5 & 6,5 & 0 & 0 \\
\hline Kamehatylus sp. & 0 & 0 & 0 & 0 & 0 & 0 & 0 & 0 & 0 & 0 & 0 \\
\hline Cerapus jonsoni & 0 & 0 & 0 & 0 & 0 & 0 & 0 & 0 & 0 & 0 & 0 \\
\hline Liljeborgia dubia & 0 & 0,5 & 2 & 0 & 0 & 1,5 & 0,5 & 0 & 0,5 & 0 & 0 \\
\hline Liljeborgia quinquedentata & 0 & 0 & 0,5 & 0 & 0 & 0 & 0 & 0,5 & 0 & 0 & 0 \\
\hline Listriella titinga & 0 & 0 & 0 & 0 & 0 & 0 & 0 & 0 & 0 & 0 & 1,5 \\
\hline Tryphosella sp.1 & 0 & 0 & 0,5 & 1,5 & 0 & 0 & 0 & 0 & 0 & 0 & 0 \\
\hline Tryphosella sp.2 & 0 & 0 & 0 & 0 & 0 & 0 & 0 & 0 & 0 & 0 & 0 \\
\hline Ceradocus sp. & 0 & 0 & 0 & 0,5 & 0 & 0 & 0 & 0 & 0 & 0 & 0 \\
\hline Dulichiella anisochir & 0 & 0 & 0,5 & 0 & 0 & 0 & 0 & 0 & 0 & 0 & 0 \\
\hline Giberosus myersi & 2,5 & 0,5 & 0 & 0 & 0 & 0,5 & 0 & 0 & 0 & 0 & 0 \\
\hline Maera sp. & 0 & 0 & 1,5 & 0,5 & 0 & 0 & 0 & 0 & 0 & 0 & 2 \\
\hline Resupinus coloni & 0 & 0 & 0,5 & 0 & 0 & 1 & 0 & 1,5 & 0 & 0 & 0 \\
\hline Pseudomegamphopus sp.n. & 0,5 & 0 & 3 & 0 & 0 & 0 & 0 & 0 & 0 & 0 & 0 \\
\hline Pseudomegamphopus barnardi & 0 & 0 & 0 & 3 & 0 & 0,5 & 0 & 0 & 0 & 0 & 0 \\
\hline Monoculodes nyei & 0 & 0 & 0 & 0 & 0 & 1,5 & 0 & 1 & 0 & 2 & 0 \\
\hline Oediceroides cinderella & 0 & 0 & 0 & 0 & 0 & 0 & 0 & 0 & 0 & 0 & 0 \\
\hline Paramonoculopsis acuta & 0 & 0 & 0 & 0 & 0 & 0 & 0 & 0 & 0 & 0 & 1,5 \\
\hline Synchelidium americanum & 0 & 0 & 2 & 0 & 0 & 1 & 0 & 0 & 0 & 0 & 2 \\
\hline Westwoodilla restirostris & 0 & 0 & 0 & 0,5 & 0 & 0 & 0 & 0 & 0 & 0 & 0 \\
\hline Halicoides? sp. & 0 & 0 & 0 & 0 & 0 & 0 & 0 & 0 & 0 & 0 & 1 \\
\hline Ampelisciphotis podophthalma & 0 & 0 & 0,5 & 0 & 0 & 0 & 0 & 0 & 0 & 0 & 7 \\
\hline Photis brevipes & 0 & 2 & 1 & 0 & 0 & 0 & 0 & 0 & 0 & 0 & 0,5 \\
\hline Photis longicaudata & 0 & 0 & 0 & 0 & 0 & 0 & 0 & 0 & 0 & 1,5 & 0,5 \\
\hline Heterophoxus videns & 0 & 5 & 11,5 & 1 & 0 & 0 & 0 & 0 & 0 & 0 & 8 \\
\hline Metharpinia sp.n. & 0 & 24 & 1 & 0 & 0 & 1 & 0 & 0 & 0 & 0 & 0 \\
\hline Metharpinia iado & 0 & 0 & 0 & 0 & 0 & 0 & 0 & 0 & 0 & 2 & 0 \\
\hline Microphoxus moaresi & 2,5 & 3 & 0 & 1 & 2 & 4,5 & 2 & 4,5 & 2 & 1,5 & 0 \\
\hline Pseudoharpinia dentata & 0 & 1,5 & 6,5 & 0 & 0 & 0 & 0 & 0 & 0 & 0 & 0,5 \\
\hline Eudevenopus gracilipes & 0 & 0 & 0 & 0 & 0 & 1 & 0 & 3 & 0 & 1 & 0 \\
\hline Tiburonella viscana & 0 & 1,5 & 0 & 0 & 0 & 0 & 0 & 1 & 0 & 1 & 0 \\
\hline Podocerus brasiliensis & 0 & 0 & 0 & 0,5 & 0 & 0 & 0 & 0 & 0 & 0 & 0 \\
\hline Tiron biocellata & 0 & 0 & 0 & 0,5 & 0 & 0,5 & 0 & 0 & 0 & 0 & 0,5 \\
\hline Tiron tropakis & 0 & 0,5 & 0 & 0 & 0 & 0 & 0 & 0 & 0 & 0 & 0 \\
\hline Syrrhoe crenulata & 0 & 0 & 0 & 0 & 0 & 0 & 0 & 0 & 0 & 0 & 0,5 \\
\hline Carangolia $s p$. & 0 & 0 & 2,5 & 0 & 0 & 0 & 0 & 0 & 0 & 0 & 0,5 \\
\hline Urothoe sp.n. & 0 & 0 & 5,5 & 2 & 0 & 0 & 0 & 0 & 0 & 0 & 13,5 \\
\hline Huerpa $s p$. & 0 & 0 & 0 & 0 & 0 & 2 & 0 & 1,5 & 0 & 0 & 0 \\
\hline Paracaprella tenuis & 0 & 0 & 1 & 0 & 0 & 0 & 0 & 0 & 0 & 0 & 0 \\
\hline TOTAL POR ESTAÇÃO/ESTRATO & 31 & 62 & 54,5 & 34,5 & 8 & 27 & 40,5 & 24,5 & 16,5 & 12,5 & 47,5 \\
\hline
\end{tabular}




\begin{tabular}{|c|c|c|c|c|c|c|c|c|c|c|c|}
\hline Espécies & $12 \mathrm{~S}$ & $13 \mathrm{~S}$ & $14 \mathrm{~S}$ & $15 \mathrm{~S}$ & $16 \mathrm{~S}$ & $17 \mathrm{~S}$ & $18 \mathrm{~S}$ & $19 \mathrm{~S}$ & $20 \mathrm{~S}$ & $21 \mathrm{~s}$ & TOTAL ESPÉCIES \\
\hline Ampelisca sp.1 & 0 & 0 & 0 & 0 & 0 & 0 & 0 & 0 & 4 & 0 & 4,5 \\
\hline Ampelisca sp.2 & 0 & 0 & 0 & 0 & 0 & 0 & 0 & 0 & 0 & 0 & 7 \\
\hline Ampelisca brevisimulata & 0 & 0 & 0 & 0,5 & 0 & 0 & 0 & 0,5 & 0 & 1 & 23,5 \\
\hline Ampelisca cristata & 0 & 0 & 0 & 1,5 & 0 & 0,5 & 0 & 0 & 1 & 0 & 4 \\
\hline Ampelisca moreirai & 0,5 & 0 & 0 & 0 & 0 & 0 & 0 & 0 & 0 & 0 & 9,5 \\
\hline Ampelisca paria & 0 & 10,5 & 7,5 & 6 & 9 & 2 & 48,5 & 6 & 0 & 0 & 187,5 \\
\hline Ampelisca pugetica & 0 & 0 & 0,5 & 0 & 0 & 0 & 0 & 0 & 0 & 0 & 4 \\
\hline Ampelisca rodriguesi & 0 & 0 & 0 & 0 & 0 & 0 & 0 & 0 & 2 & 0 & 15 \\
\hline Ampelisca romigi & 0 & 0 & 0 & 0 & 0 & 0 & 0 & 0 & 0 & 0 & 13,5 \\
\hline Ampelisca subtropicalis & 0 & 0 & 0 & 0 & 0 & 0 & 0 & 0 & 0 & 0 & 0,5 \\
\hline Gitanopsis sp. & 0 & 0 & 0 & 0 & 0 & 0,5 & 0 & 0 & 0 & 0 & 1,5 \\
\hline Amphitoe ramondi & 0 & 0 & 0 & 0 & 0 & 0 & 0 & 0,5 & 0 & 0 & 0,5 \\
\hline Lembos sp. & 0 & 0 & 0 & 0 & 0 & 0 & 0 & 0 & 0 & 1,5 & 4 \\
\hline Che irophotis megacheles & 0 & 0 & 0 & 0 & 0 & 0 & 0 & 0,5 & 0 & 0 & 1,5 \\
\hline Cheirophotis neotropicalis & 0 & 0 & 0 & 0 & 0 & 0 & 0 & 0,5 & 0 & 0 & 8,5 \\
\hline Kamehatylus sp. & 0 & 0 & 0 & 0 & 0,5 & 0 & 0 & 0 & 0 & 0 & 0,5 \\
\hline Cerapus jonsoni & 0 & 0 & 0 & 0 & 0 & 0 & 0 & 0,5 & 0 & 0 & 0,5 \\
\hline Liljeborgia dubia & 0 & 0 & 0 & 0 & 0 & 0 & 0 & 0 & 0 & 0 & 5 \\
\hline Liljeborgia quinquedentata & 0 & 0 & 0 & 0,5 & 0 & 0 & 0 & 0 & 0 & 0 & 1,5 \\
\hline Listriella titinga & 0 & 0 & 0 & 0 & 0 & 0 & 0 & 0 & 0 & 0 & 1,5 \\
\hline Tryphosella sp.1 & 0 & 0 & 0 & 0 & 0 & 0 & 0 & 0 & 0,5 & 0 & 2,5 \\
\hline Tryphosella sp.2 & 0 & 0 & 0 & 0 & 0 & 0 & 0 & 0 & 1 & 0 & 1 \\
\hline Ceradocus sp. & 0 & 0 & 0 & 0 & 0 & 0 & 0 & 0 & 0 & 0 & 0,5 \\
\hline Dulichiella anisochir & 0 & 0 & 0 & 0 & 0 & 0 & 0 & 0 & 0 & 0 & 0,5 \\
\hline Giberosus myersi & 0 & 0 & 0 & 0 & 0 & 0 & 0 & 1 & 0 & 0 & 4,5 \\
\hline Maera sp. & 1,5 & 0 & 0 & 0 & 0 & 0 & 0 & 0 & 0 & 0,5 & 6 \\
\hline Resupinus coloni & 0 & 0 & 0,5 & 2 & 2,5 & 2 & 0 & 0 & 0 & 0 & 10 \\
\hline Pseudomegamphopus sp.n. & 3 & 0 & 4 & 1,5 & 0 & 0,5 & 0 & 2,5 & 0 & 0 & 15 \\
\hline Pseudomegamphopus barnardi & 0 & 0 & 0 & 0 & 0 & 0 & 0 & 0 & 0 & 0 & 3,5 \\
\hline Monoculodes nyei & 0 & 0 & 0,5 & 0 & 0 & 2,5 & 0 & 3 & 0 & 0 & 10,5 \\
\hline Oediceroides cinderella & 0 & 0,5 & 0 & 0 & 3 & 0 & 0,5 & 0 & 0 & 0 & 4 \\
\hline Paramonoculopsis acuta & 0 & 0 & 0 & 0 & 0 & 0 & 0 & 0 & 1,5 & 0 & 3 \\
\hline Synchelidium americanum & 0 & 0 & 0 & 0 & 0 & 0 & 0 & 0 & 3 & 0 & 8 \\
\hline Westwoodilla restirostris & 0 & 0 & 0 & 0 & 0 & 0 & 0 & 0 & 0 & 0 & 0,5 \\
\hline Halicoides? sp. & 0 & 0 & 0 & 0 & 0 & 0 & 0 & 0 & 0 & 0 & 1 \\
\hline Ampelisciphotis podophthalma & 0 & 0 & 0 & 0 & 0 & 0 & 0 & 0 & 0 & 0 & 7,5 \\
\hline Photis brevipes & 0 & 0 & 0,5 & 0 & 0 & 0,5 & 0 & 0,5 & 0 & 0 & 5 \\
\hline Photis longicaudata & 0 & 0 & 0 & 0 & 0 & 0 & 0 & 0 & 0 & 0 & 2 \\
\hline Heterophoxus videns & 1 & 0 & 0 & 0 & 0 & 0 & 0 & 0 & 14 & 0 & 40,5 \\
\hline Metharpinia sp.n. & 0 & 0 & 0 & 0 & 0 & 0 & 0 & 0 & 69,5 & 0 & 95,5 \\
\hline Metharpinia iado & 0 & 0 & 0 & 0,5 & 0 & 0 & 0 & 0 & 0 & 0 & 2,5 \\
\hline Microphoxus moaresi & 0 & 0 & 2 & 1 & 1 & 5 & 0,5 & 3 & 0 & 0 & 35,5 \\
\hline Pseudoharpinia dentata & 11 & 0 & 0 & 0 & 0 & 0 & 0 & 0 & 0 & 1 & 20,5 \\
\hline Eudevenopus gracilipes & 0 & 0 & 3 & 0,5 & 0 & 2 & 0 & 3,5 & 0 & 0 & 14 \\
\hline Tiburonella viscana & 0 & 0 & 0 & 0 & 0 & 0 & 0 & 0 & 0 & 0 & 3,5 \\
\hline Podocerus brasiliensis & 0 & 0 & 0 & 0 & 0 & 0 & 0 & 0 & 0 & 0 & 0,5 \\
\hline Tiron biocellata & 0 & 0 & 0 & 0,5 & 0 & 0 & 0 & 0,5 & 0 & 0 & 2,5 \\
\hline Tiron tropakis & 0 & 0 & 1 & 0 & 0 & 0 & 0 & 0 & 0,5 & 0 & 2 \\
\hline Syrrhoe crenulata & 0 & 0 & 0 & 0 & 0 & 0 & 0 & 0 & 0,5 & 0 & 1 \\
\hline Carangolia sp. & 2,5 & 0 & 0 & 0 & 0 & 0 & 0 & 0 & 0 & 0 & 5,5 \\
\hline Urothoe sp.n. & 2 & 0 & 0 & 0 & 0 & 0 & 0 & 0 & 22,5 & 0 & 45,5 \\
\hline Huerpa $s p$. & 0 & 0 & 0 & 0 & 0 & 0 & 2,5 & 0 & 0 & 0 & 6 \\
\hline Paracaprella pusilla & 0 & 0,5 & 0 & 0 & 0 & 0 & 0 & 0 & 0 & 0 & 1,5 \\
\hline TOTAL POR ESTAÇÃO/ESTRATO & 21,5 & 11,5 & 19,5 & 14,5 & 16 & 15,5 & 52 & 22,5 & 120 & 4 & 655,5 \\
\hline
\end{tabular}


Anexo III - Densidade das espécies encontradas no Estrato de Meio (M) na campanha de inverno (agosto e setembro de 2005) nas estações amostradas na Plataforma Continental da Baixada Santista.

\begin{tabular}{|c|c|c|c|c|c|c|c|c|c|c|c|c|c|c|c|c|c|c|c|}
\hline Espécies & $1 \mathrm{M}$ & $2 M$ & $3 \mathbf{M}$ & $4 M$ & $6 \mathrm{M}$ & $7 M$ & $8 \mathrm{M}$ & $9 M$ & $10 \mathrm{M}$ & $11 \mathrm{M}$ & $12 \mathrm{M}$ & $13 \mathrm{M}$ & $14 M$ & $16 M$ & $17 \mathrm{M}$ & $18 \mathrm{M}$ & $20 M$ & $21 \mathrm{M}$ & TOTAL ESPÉCIES \\
\hline Ampelisca brevisimulata & 0 & 4 & 1 & 0 & 0,5 & 0 & 0 & 0 & 0 & 0 & 0 & 0 & 0 & 0 & 0 & 0 & 0 & 0 & 5,5 \\
\hline Ampelisca cristata & 0 & 0 & 0 & 0,5 & 0 & 0 & 0 & 0 & 0,5 & 0 & 0 & 0 & 0 & 0 & 0 & 0 & 0 & 0 & 1 \\
\hline Ampelisca moreirai & 0 & 0,5 & 0,5 & 0 & 0 & 0 & 0 & 0 & 0 & 0 & 0 & 0 & 0 & 0 & 0 & 0 & 2 & 0 & 3 \\
\hline Ampelisca paria & 3 & 0 & 0 & 0 & 5,5 & 3 & 0 & 0 & 1 & 0 & 0 & 1 & 3,5 & 0,5 & 0 & 1,5 & 0 & 0 & 19 \\
\hline Ampelisca pugetica & 0 & 0 & 0 & 0,5 & 0 & 0 & 0 & 0 & 0 & 0 & 0 & 0 & 0 & 0 & 0 & 0 & 0 & 0 & 0,5 \\
\hline Ampelisca romigi & 0 & 0 & 0 & 0,5 & 0 & 0 & 0 & 0 & 0 & 0,5 & 0 & 0 & 0 & 0 & 0 & 0 & 0 & 0 & 1 \\
\hline Gitanopsis sp. & 0 & 0 & 0 & 0 & 0 & 0 & 0 & 0 & 0 & 0,5 & 0 & 0 & 0 & 0 & 0 & 0 & 0 & 0 & 0,5 \\
\hline Lembos sp. & 0 & 0 & 0 & 0 & 0 & 0 & 0 & 0 & 0 & 0 & 0 & 0 & 0 & 0 & 0 & 0 & 0 & 2 & 2 \\
\hline Cheirophotis neotropicalis & 0 & 0 & 0 & 0 & 0 & 0 & 0 & 1 & 0 & 0,5 & 0 & 0 & 0 & 0 & 0 & 0 & 0 & 0 & 1,5 \\
\hline Kamehatylus sp. & 0 & 0 & 0 & 0 & 0 & 0 & 0,5 & 0 & 0 & 0 & 0 & 0 & 0 & 0 & 0 & 0 & 0 & 0 & 0,5 \\
\hline Liljeborgia dubia & 0 & 0,5 & 1 & 0 & 0 & 0 & 0 & 0 & 0 & 0 & 0 & 0 & 0,5 & 0 & 0 & 0 & 0 & 0 & 2 \\
\hline Liljeborgia quinquedentata & 0 & 0 & 0,5 & 0 & 2 & 0,5 & 0 & 0 & 0,5 & 0 & 0 & 0 & 0 & 0 & 0 & 0 & 0,5 & 0 & 4 \\
\hline Listriella titinga & 0 & 0 & 0 & 0 & 0 & 0 & 0 & 0 & 0,5 & 0 & 0 & 0 & 0 & 0 & 0 & 0 & 0 & 0 & 0,5 \\
\hline Prachynella sp. & 0 & 0 & 0,5 & 0 & 0 & 0 & 0 & 0 & 0 & 0 & 0 & 0 & 0 & 0 & 0 & 0 & 0 & 0 & 0,5 \\
\hline Tryphosella sp.1 & 0 & 0 & 0,5 & 0 & 0 & 0 & 0 & 0 & 0 & 0 & 0 & 0 & 0 & 0 & 0 & 0 & 0 & 0 & 0,5 \\
\hline Resupinus coloni & 0 & 0 & 0 & 0 & 0 & 0 & 1 & 0 & 0 & 0 & 0 & 0 & 0 & 0 & 0 & 0 & 0 & 0 & 1 \\
\hline Pseudomegamphopus sp.n. & 0 & 0 & 0,5 & 0 & 0 & 0 & 0 & 0 & 0 & 0 & 0 & 0 & 0 & 0 & 0 & 0 & 0 & 0 & 0,5 \\
\hline Pseudomegamphopus barnardi & 0 & 0 & 0 & 0,5 & 0,5 & 0 & 0 & 0 & 0 & 0 & 0 & 0 & 0 & 0 & 0 & 0 & 0 & 0 & 1 \\
\hline Synchelidium americanum & 0 & 0 & 0,5 & 0 & 0 & 0 & 0 & 0 & 0 & 0 & 0 & 0 & 0 & 0 & 0 & 0 & 0 & 0 & 0,5 \\
\hline Halicoides ? Sp. & 0 & 0 & 0 & 0 & 0 & 0 & 0 & 0 & 0 & 0,5 & 0 & 0 & 0 & 0 & 0 & 0 & 0 & 0 & 0,5 \\
\hline Ampelisciphotis podophthalma & 0 & 0 & 0 & 0 & 0 & 0 & 0 & 0 & 0 & 0,5 & 0 & 0 & 0 & 0 & 0 & 0 & 0 & 0 & 0,5 \\
\hline Heterophoxus videns & 0 & 0,5 & 1,5 & 0 & 0 & 0 & 0 & 0 & 0 & 0,5 & 0 & 0 & 0 & 0 & 0 & 0 & 0,5 & 0 & 3 \\
\hline Metharpinia sp.n. & 0 & 4 & 0,5 & 0 & 0,5 & 0 & 0 & 0 & 0 & 0 & 0 & 0 & 0 & 0 & 0 & 0 & 3,5 & 0 & 8,5 \\
\hline Microphoxus moaresi & 0 & 0,5 & 0 & 0 & 2,5 & 1 & 0 & 0 & 0,5 & 0 & 0 & 0 & 0,5 & 1 & 4 & 0 & 0 & 0 & 10 \\
\hline Pseudoharpinia dentata & 0 & 1,5 & 2,5 & 0 & 0 & 0 & 0 & 0 & 0 & 0 & 1,5 & 0 & 0 & 0 & 0 & 0 & 0 & 0 & 5,5 \\
\hline Eudevenopus gracilipes & 0 & 0 & 0 & 0 & 0 & 0 & 0,5 & 0 & 0 & 0 & 0 & 0 & 0,5 & 0 & 0 & 0 & 0 & 0 & 1 \\
\hline Tiburonella viscana & 0 & 1 & 0 & 0 & 0 & 0 & 0 & 0 & 0,5 & 0 & 0 & 0 & 0 & 0 & 0 & 0 & 0 & 0 & 1,5 \\
\hline Tiron biocellata & 0 & 0 & 0 & 0 & 0 & 0 & 0 & 0 & 1 & 0,5 & 0 & 0 & 0 & 0 & 0 & 0 & 0 & 0 & 1,5 \\
\hline Urothoe sp.n. & 0 & 0 & 0 & 0 & 0 & 0 & 0 & 0 & 0 & 1,5 & 0 & 0 & 0 & 0 & 0 & 0 & 4 & 0,5 & 6 \\
\hline Paracaprella tenuis & 0 & 0 & 0 & 0 & 0 & 0 & 0 & 0 & 0 & 0 & 0 & 0,5 & & 0 & 0 & 0 & 0 & 0 & 0,5 \\
\hline TOTAL POR ESTAÇÃO/ESTRATO & 3 & 12,5 & 9,5 & 2 & 11,5 & 4,5 & 2 & 1 & 4,5 & 5 & 1,5 & 1,5 & 5 & 1,5 & 4 & 1,5 & 10,5 & 2,5 & 83 \\
\hline
\end{tabular}


Anexo IV - Densidade das espécies encontradas no Estrato Inferior na campanha de inverno (agosto e setembro de 2005) nas estações amostradas na Plataforma Continental da Baixada Santista.

\begin{tabular}{|c|c|c|c|c|c|c|c|c|c|c|c|c|c|c|c|c|c|c|c|}
\hline Espécies & $1 \mathrm{~F}$ & $2 \mathrm{~F}$ & $3 \mathbf{F}$ & $4 \mathrm{~F}$ & $5 \mathrm{~F}$ & $6 \mathrm{~F}$ & $7 \mathrm{~F}$ & $8 \mathrm{~F}$ & $9 \mathrm{~F}$ & $10 \mathrm{~F}$ & $13 \mathrm{~F}$ & $14 \mathrm{~F}$ & $15 \mathrm{~F}$ & $16 \mathrm{~F}$ & $17 \mathrm{~F}$ & $18 \mathrm{~F}$ & $19 \mathrm{~F}$ & $20 \mathrm{~F}$ & TOTAL ESPÉCIES \\
\hline Ampelisca sp.1 & 0 & 0 & 2,5 & 0 & 0 & 0 & 0 & 0 & 0 & 0 & 0 & 0 & 0 & 0 & 0 & 0 & 0 & 0 & 2,5 \\
\hline Ampelisca brevisimulata & 0 & 1 & 0 & 0 & 0 & 2 & 0 & 0 & 0 & 0 & 0 & 0 & 0 & 0 & 0 & 0 & 0 & 0 & 3 \\
\hline Ampelisca moreirai & 0 & 0 & 0 & 0 & 0 & 1,5 & 0 & 0 & 0 & 0 & 0 & 0 & 0 & 0 & 0 & 0 & 0 & 0 & 1,5 \\
\hline Ampelisca paria & 0,5 & 0 & 0 & 0 & 0,5 & 8 & 0,5 & 0 & 0 & 0,5 & 1 & 3 & 0 & 1 & 0 & 1 & 0 & 0 & 16 \\
\hline Ampelisca pugetica & 0 & 0 & 0 & 0 & 0 & 1 & 0 & 0 & 0 & 0 & 0 & 0 & 0 & 0 & 0 & 0 & 0 & 0 & 1 \\
\hline Ampelisca rodriguesi & 0 & 0 & 0 & 0,5 & 0 & 0 & 0 & 0 & 0 & 0 & 0 & 0 & 0 & 0 & 0 & 0 & 0 & 0 & 0,5 \\
\hline Ampelisca romigi & 0 & 0 & 0 & 2 & 0 & 0 & 0 & 0 & 0 & 0 & 0 & 0 & 0 & 0 & 0 & 0 & 0 & 0 & 2 \\
\hline Ampelisca subtropicalis & 0 & 0 & 0,5 & 0 & 0 & 0 & 0 & 0 & 0 & 0 & 0 & 0 & 0 & 0 & 0 & 0 & 0 & 0 & 0,5 \\
\hline Amphithoe ramondi & 0 & 0 & 0 & 0 & 0 & 0 & 0 & 0 & 0 & 0 & 0 & 0 & 0 & 0 & 0 & 0 & 0,5 & 0 & 0,5 \\
\hline Lembos $s p$. & 0 & 0 & 0 & 0 & 0 & 0 & 0 & 0 & 0 & 0 & 0 & 0,5 & 0 & 0 & 0 & 0 & 0 & 0 & 0,5 \\
\hline Cheirophotis neotropicalis & 0 & 0 & 0 & 0 & 0 & 0 & 0 & 0 & 1 & 0 & 0 & 0 & 0 & 0 & 0 & 0 & 0 & 0 & 1 \\
\hline Kamehatylus sp. & 0 & 0 & 0 & 0 & 0 & 0,5 & 0 & 0 & 0 & 0 & 0 & 0 & 0 & 0 & 0 & 0 & 0 & 0 & 0,5 \\
\hline Liljeborgia dubia & 0 & 0 & 1 & 0 & 0 & 0 & 0 & 0 & 0 & 0 & 0 & 0 & 0 & 0 & 0 & 0 & 0 & 0 & 1 \\
\hline Liljeborgia quinquedentata & 0 & 0 & 0 & 0 & 0 & 2 & 0 & 0 & 0 & 0,5 & 0 & 0 & 0 & 0 & 0 & 0 & 0 & 0,5 & 3 \\
\hline Giberosus myersi & 0 & 0 & 0 & 0 & 0 & 0,5 & 0 & 0 & 0 & 0 & 0 & 0 & 0 & 0 & 0 & 0 & 0 & 0 & 0,5 \\
\hline Maera sp. & 0 & 0 & 0 & 0 & 0 & 0 & 0 & 0,5 & 0 & 0 & 0 & 0 & 0 & 0 & 0 & 0 & 0 & 0 & 0,5 \\
\hline Resupinus coloni & 0 & 0 & 0 & 0 & 0 & 0 & 0 & 0 & 0 & 0 & 0 & 0 & 0,5 & 0 & 0 & 0 & 0 & 0 & 0,5 \\
\hline Monoculodes nyei & 0 & 0 & 0 & 0 & 0 & 0 & 0 & 0 & 0 & 0 & 0 & 0 & 0,5 & 0 & 0 & 0 & 0 & 0 & 0,5 \\
\hline Metharpinia sp.n. & 0 & 0,5 & 0 & 0 & 0 & 0 & 0 & 0 & 0 & 0 & 0 & 0 & 0 & 0 & 0 & 0 & 0 & 0,5 & 1 \\
\hline Microphoxus moaresi & 0 & 0 & 0 & 0 & 0 & 1,5 & 0 & 0 & 0 & 0 & 0 & 0,5 & 0 & 0 & 0,5 & 0 & 0 & 0 & 2,5 \\
\hline Pseudoharpinia dentata & 0 & 0,5 & 2 & 0 & 0 & 1 & 0 & 0 & 0 & 0 & 0 & 0 & 0 & 0 & 0 & 0 & 0 & 0 & 3,5 \\
\hline Eudevenopus gracilipes & 0 & 0 & 0 & 0 & 0 & 0,5 & 0 & 0 & 0 & 0 & 0 & 0 & 0 & 0 & 0 & 0 & 0 & 0 & 0,5 \\
\hline Tiron biocellata & 0 & 0 & 0 & 0 & 0 & 0 & 0 & 0,5 & 0 & 10 & 0 & 0 & 0 & 0 & 0 & 0 & 0 & 0 & 10,5 \\
\hline Carangolia sp. & 0 & 0 & 0 & 0 & 0 & 0,5 & 0 & 0 & 0 & 0 & 0 & 0 & 0 & 0 & 0 & 0 & 0 & 0 & 0,5 \\
\hline Paracaprella pusilla & 0 & 0 & 0 & 0 & 0 & 0 & 0 & 0 & 0 & 0 & 0 & 0 & 0 & 0 & 0 & 0 & 1 & 0 & 1 \\
\hline TOTAL POR ESTAÇÃO/ESTRATO & 0,5 & 2 & 6 & 2,5 & 0,5 & 19 & 0,5 & 1 & 1 & 11 & 1 & 4 & 1 & 1 & 0,5 & 1 & 1,5 & 1 & 55 \\
\hline
\end{tabular}


Anexo V - Densidade das espécies encontradas no Estrato de Superfície (S) na campanha de verão (fevereiro de 2006) nas estações amostradas na Plataforma Continental da Baixada Santista.

\begin{tabular}{|c|c|c|c|c|c|c|c|c|c|c|c|}
\hline Espécies & $1 S$ & $2 S$ & 35 & $4 S$ & $5 S$ & $6 S$ & $7 S$ & $8 S$ & 95 & $10 S$ & 115 \\
\hline Ampelisca brevisimulata & 0 & 7,5 & 1 & 0 & 0 & 3 & 0 & 0 & 0 & 2 & 1 \\
\hline Ampelisca cristata & 0 & 0 & 0 & 0 & 0 & 2 & 0 & 2 & 0 & 2,5 & 0 \\
\hline Ampelisca moreirai & 0 & 2,5 & 0 & 2 & 0 & 0 & 0 & 0 & 0 & 0 & 0,5 \\
\hline Ampelisca paria & 21 & 0 & 0 & 0 & 4 & 0,5 & 12 & 0 & 0 & 0 & 0 \\
\hline Ampelisca pugetica & 0 & 0 & 1 & 0 & 0 & 1,5 & 0 & 0 & 0 & 0 & 3 \\
\hline Ampelisca rodriguesi & 0 & 0 & 0 & 12,5 & 0 & 0 & 0 & 0 & 0 & 0 & 0,5 \\
\hline Ampelisca romigi & 0,5 & 0 & 0 & 5,5 & 0 & 0 & 0 & 0 & 0 & 0 & 0 \\
\hline Gitanopsis sp. & 0 & 11,5 & 1 & 0 & 0 & 7 & 0 & 6,5 & 0 & 4,5 & 0,5 \\
\hline Lembo sp. & 0 & 0 & 0 & 0 & 0,5 & 0 & 1 & 1,5 & 0,5 & 0,5 & 1,5 \\
\hline Aorcho ?sp. & 0 & 0,5 & 0 & 2,5 & 0 & 0 & 0 & 0 & 0 & 0 & 0 \\
\hline Cheirophotis megacheles & 0 & 1 & 0 & 0 & 0 & 0 & 0 & 0 & 0 & 0 & 0 \\
\hline Cheirophotis neotropicalis & 0 & 0 & 0 & 0 & 0 & 0 & 0 & 0 & 0 & 0 & 0 \\
\hline Leptocheiru? sp. & 0 & 0 & 0 & 0 & 0 & 0 & 0 & 0 & 0 & 0 & 0 \\
\hline Monocorophium acherusicum & 0 & 0,5 & 0 & 0 & 0 & 0 & 0 & 0 & 0 & 0 & 0 \\
\hline Kamehatylus sp. & 3 & 0 & 0 & 0 & 0 & 0 & 0 & 0 & 0,5 & 0 & 0 \\
\hline Eusirus sp. & 0 & 0 & 0,5 & 0 & 0 & 0 & 0 & 0 & 0 & 0 & 0 \\
\hline Cerapus jonsoni & 0 & 0 & 1 & 0 & 0 & 0 & 0 & 0 & 0 & 0 & 0 \\
\hline Liljeborgia dubia & 0 & 0,5 & 0 & 0 & 0 & 0 & 0 & 0 & 0 & 0 & 0 \\
\hline Liljeborgia quinquedentata & 0,5 & 7,5 & 4 & 0 & 1 & 10 & 2 & 1,5 & 2,5 & 0 & 0,5 \\
\hline Listriella titinga & 0 & 0 & 0 & 0 & 0 & 0 & 0 & 0 & 0 & 1,5 & 0 \\
\hline Prachynellasp. & 0 & 0 & 0,5 & 0 & 0 & 0 & 0 & 0 & 0 & 0 & 0 \\
\hline Tryphosella sp.1 & 0 & 0 & 0 & 1 & 0 & 0 & 0,5 & 0 & 0 & 0 & 0 \\
\hline Tryphosella sp.2 & 0 & 0,5 & 0 & 0,5 & 0 & 0 & 0 & 1,5 & 0 & 0,5 & 0 \\
\hline Giberosus myersi & 0 & 0 & 0 & 0 & 0 & 0 & 0 & 0 & 0 & 0 & 0 \\
\hline Maera sp. & 0 & 0 & 0 & 0 & 0 & 0 & 0 & 0 & 0 & 0 & 0 \\
\hline Resupinus coloni & 2 & 3 & 0 & 0 & 1 & 0 & 0,5 & 4 & 0 & 1,5 & 0 \\
\hline Pseudomegamphopus sp.n. & 2,5 & 0,5 & 0 & 0 & 0 & 2 & 0 & 0 & 0 & 1,5 & 0 \\
\hline Pseudomegamphopus barnardi & 0 & 0 & 0 & 4,5 & 0 & 0 & 0 & 0 & 0 & 0 & 0 \\
\hline Monoculodes nyei & 0 & 0 & 0 & 0 & 0 & 0 & 0 & 2 & 0 & 1 & 0 \\
\hline Paramonoculopsis acuta & 4 & 0 & 0 & 0 & 2 & 0 & 0,5 & 0,5 & 0 & 0 & 0 \\
\hline Synchelidium americanum & 0 & 0 & 0,5 & 0 & 0 & 0 & 0 & 0 & 0 & 0,5 & 0 \\
\hline Halicoide ?sp. & 0 & 0 & 0 & 0 & 0 & 0 & 0 & 0,5 & 0 & 0 & 0 \\
\hline Ampelisciphotis podophthalma & 0 & 0 & 0 & 10 & 0 & 0 & 0 & 0 & 0 & 0 & 3,5 \\
\hline Photis brevipes & 0 & 8 & 0 & 1,5 & 0 & 6 & 0 & 8 & 0 & 5 & 1 \\
\hline Photis longicaudata & 2 & 1 & 0 & 6 & 0,5 & 4 & 0,5 & 0 & 0 & 0 & 0,5 \\
\hline Heterophoxus videns & 0 & 8 & 4,5 & 0 & 0 & 13 & 0 & 0 & 0 & 0 & 3,5 \\
\hline Metharpinia sp.n. & 0 & 39,5 & 0 & 0 & 0 & 0 & 0 & 0 & 0 & 0 & 0 \\
\hline Metharpinia iado & 0 & 0 & 0 & 0,5 & 0 & 0 & 0 & 0 & 0 & 0,5 & 0 \\
\hline Microphoxus moaresi & 1,5 & 0 & 0 & 0 & 1 & 13 & 2 & 3 & 7 & 1 & 0,5 \\
\hline Pseudoharpinia dentata & 0 & 0,5 & 12 & 0 & 0 & 0 & 0 & 0 & 0 & 0 & 0 \\
\hline Eudevenopus gracilipes & 0 & 0 & 0 & 0 & 0 & 0,5 & 0 & 1,5 & 0,5 & 3 & 0 \\
\hline Tiburonella viscana & 0 & 4 & 0 & 0 & 0 & 0 & 0 & 0 & 0 & 0,5 & 0 \\
\hline Podocerus brasiliensis & 0 & 0 & 0 & 0 & 0 & 0 & 0 & 0,5 & 0 & 1,5 & 0 \\
\hline Parametopella ninis & 0 & 0,5 & 0 & 5 & 0 & 0,5 & 0 & 2 & 3 & 0 & 0 \\
\hline Tiron biocellata & 0 & 1 & 0 & 0 & 0 & 0,5 & 0 & 0,5 & 0 & 0,5 & 0 \\
\hline Tiron tropakis & 0 & 0,5 & 0 & 1,5 & 0 & 0,5 & 0 & 0 & 0 & 0,5 & 0,5 \\
\hline Carangolia sp. & 0 & 0 & 0 & 0 & 0 & 0 & 0 & 0 & 0 & 0 & 0 \\
\hline Urothoe sp.n. & 0 & 0 & 1 & 2 & 0 & 0 & 0 & 0 & 0 & 0 & 5,5 \\
\hline Huerpa ? sp. & 0 & 0 & 0 & 0 & 0 & 8 & 0 & 0,5 & 0 & 0 & 0 \\
\hline Paracaprella pusilla & 0 & 0 & 0 & 0 & 0 & 0 & 0 & 0 & 0 & 0 & 0 \\
\hline Paracaprella tenuis & 0 & 0,5 & 0 & 0 & 0 & 0 & 0 & 0 & 0 & 2,5 & 0,5 \\
\hline TOTAL POR ESTAÇÃO/ ESTRATO & 37 & 99 & 27 & 55 & 10 & 72 & 19 & 36 & 14 & 31 & 23 \\
\hline
\end{tabular}


Anexo VI - Continuação.

\begin{tabular}{|c|c|c|c|c|c|c|c|c|c|c|c|}
\hline Espécies & $12 S$ & 135 & $14 S$ & $15 \mathrm{~S}$ & $16 S$ & $17 S$ & $18 \mathrm{~S}$ & 195 & 205 & 215 & TOTAL ESPÉCIES \\
\hline Ampelisca brevisimulata & 0 & 0 & 2 & 0 & 0 & 0 & 0 & 0,5 & 0 & 0 & 17 \\
\hline Ampelisca cristata & 0 & 0 & 1,5 & 2 & 0 & 0 & 0 & 0 & 1 & 0 & 11 \\
\hline Ampelisca moreirai & 0 & 0 & 0,5 & 0,5 & 0 & 0 & 0 & 0 & 1,5 & 0 & 7,5 \\
\hline Ampelisca paria & 0 & 9,5 & 3,5 & 0 & 11,5 & 1,5 & 18 & 1,5 & 0 & 0 & 83 \\
\hline Ampelisca pugetica & 0 & 0 & 0 & 0 & 0 & 0 & 0 & 0 & 1,5 & 1,5 & 8,5 \\
\hline Ampelisca rodriguesi & 0 & 0 & 0 & 0 & 0 & 0 & 0 & 0 & 0 & 0 & 13 \\
\hline Ampelisca romigi & 0 & 0 & 0 & 0 & 0 & 0 & 0 & 0 & 0,5 & 0,5 & 7 \\
\hline Gitanopsis sp. & 0 & 0 & 18 & 3 & 0 & 3,5 & 0 & 0 & 15 & 0 & 70,5 \\
\hline Lembo sp. & 0 & 0 & 0 & 0 & 0 & 1,5 & 0 & 1 & 0 & 6,5 & 14,5 \\
\hline Aorcho sp. & 0 & 0 & 0 & 0 & 0 & 0 & 0 & 0 & 0 & 0 & 3 \\
\hline Cheirophotis megacheles & 0 & 0 & 3,5 & 0 & 0 & 0 & 0 & 0 & 0 & 0 & 4,5 \\
\hline Cheirophotis neotropicalis & 0 & 0 & 0 & 0 & 0,5 & 0 & 0 & 0 & 0 & 0 & 0,5 \\
\hline Leptocheirus?sp. & 0 & 0 & 0 & 0 & 0 & 0 & 0 & 0 & 0,5 & 0 & 0,5 \\
\hline Monocorophium acherusicum & 0 & 0 & 0 & 0 & 0 & 0 & 0 & 0 & 0 & 0 & 0,5 \\
\hline Kamehatylus sp. & 0 & 0 & 0 & 0 & 0 & 0 & 0 & 0 & 0 & 0 & 3,5 \\
\hline Eusirus sp. & 0 & 0 & 0 & 0 & 0 & 0 & 0 & 0 & 0 & 0 & 0,5 \\
\hline Cerapus jonsoni & 0 & 0 & 0 & 0 & 0 & 0 & 0 & 0 & 0 & 0 & 1 \\
\hline Liljeborgia dubia & 0 & 0 & 0 & 0 & 0 & 0 & 0 & 0 & 0 & 0 & 0,5 \\
\hline Liljeborgia quinquedentata & 0 & 0 & 1,5 & 3 & 0 & 0 & 0 & 0 & 0 & 0 & 34 \\
\hline Listriella titinga & 0 & 0 & 0 & 0 & 0 & 0 & 0 & 0 & 0 & 0 & 1,5 \\
\hline Prachynellasp. & 0 & 0 & 0 & 0 & 0 & 0 & 0 & 0 & 0 & 0 & 0,5 \\
\hline Tryphosella sp.1 & 0 & 0 & 0 & 0 & 0 & 0 & 0 & 0 & 1,5 & 0 & 3 \\
\hline Tryphosella sp.2 & 0 & 0 & 1 & 0,5 & 0 & 0,5 & 0 & 0 & 0,5 & 0 & 5,5 \\
\hline Giberosus myersi & 0 & 0 & 2 & 0 & 0 & 0 & 0 & 0 & 0 & 0 & 2 \\
\hline Maera sp. & 0 & 0 & 0 & 0 & 0 & 0 & 0 & 0 & 0 & 1,5 & 1,5 \\
\hline Resupinus coloni & 0 & 0,5 & 30 & 0,5 & 1 & 2 & 0 & 1 & 2 & 0 & 49 \\
\hline Pseudomegamphopus sp.n & 0 & 1 & 63,5 & 0,5 & 0 & 0 & 0 & 0 & 0 & 3,5 & 75 \\
\hline Pseudomegamphopus barnardi & 0 & 2 & 0 & 0 & 0,5 & 0 & 0 & 0 & 0 & 0 & 7 \\
\hline Monoculodes nyei & 0 & 0 & 6 & 0,5 & 0 & 5 & 0 & 2,5 & 0 & 0 & 17 \\
\hline Paramonoculopsis aauta & 0 & 0,5 & 0 & 0 & 1,5 & 0 & 0 & 0 & 2 & 0 & 11 \\
\hline Synchelidiumamericanum & 0 & 0 & 0 & 0,5 & 0 & 0 & 0 & 0 & 0 & 0 & 1,5 \\
\hline Halicoide? sp. & 0 & 0 & 0 & 0 & 0 & 0 & 0 & 0 & 0 & 0 & 0,5 \\
\hline Ampelisciphotis podophthalma & 0 & 0 & 0 & 0 & 0 & 0 & 0 & 0 & 0 & 0 & 13,5 \\
\hline Photis brevipes & 0 & 0 & 5 & 3 & 0 & 1 & 0 & 1,5 & 0,5 & 0 & 40,5 \\
\hline Photis longicaudata & 0 & 0 & 0 & 0 & 0,5 & 0 & 0 & 0 & 0 & 0 & 15 \\
\hline Heterophoxus videns & 2,5 & 0 & 0 & 0 & 0 & 0 & 0 & 0 & 6 & 3 & 40,5 \\
\hline Metharpinia sp.n. & 0 & 0 & 0 & 0 & 0 & 0 & 0 & 0 & 30 & 0 & 69,5 \\
\hline Metharpinia iado & 0 & 0 & 0 & 1,5 & 0 & 0 & 0 & 0 & 0 & 0 & 2,5 \\
\hline Microphoxus moaresi & 0 & 3 & 3 & 1,5 & 4 & 11,5 & 5,5 & 2 & 0,5 & 0 & 60 \\
\hline Pseudoharpinia dentata & 1 & 0 & 0 & 0 & 0 & 0 & 0 & 0 & 0 & 1,5 & 15 \\
\hline Eudevenopus gracilipes & 0 & 0 & 7,5 & 0 & 0 & 4,5 & 0 & 2,5 & 0 & 0 & 20 \\
\hline Tiburonella viscana & 0 & 0 & 0 & 0 & 0 & 0 & 0 & 0 & 0 & 0 & 4,5 \\
\hline Podocerus brasiliensis & 0 & 0 & 0 & 0 & 0 & 0 & 0 & 0 & 3,5 & 0 & 5,5 \\
\hline Parametopella ninis & 0 & 0 & 1,5 & 1,5 & 0 & 0 & 0 & 0 & 0 & 0 & 14 \\
\hline Tiron biocellata & 0 & 0 & 0 & 0 & 0 & 0 & 0 & 0 & 0 & 0 & 2,5 \\
\hline Tiron tropakis & 0 & 0 & 0 & 0 & 0 & 0 & 0 & 0 & 1 & 0 & 4,5 \\
\hline Carangolia sp. & 0,5 & 0 & 0 & 0 & 0 & 0 & 0 & 0 & 0 & 2,5 & 3 \\
\hline Urothoe sp.n. & 1,5 & 0 & 0 & 0 & 0 & 0 & 0 & 0 & 27,5 & 0 & 37,5 \\
\hline Huerpa ? sp. & 0 & 0 & 7,5 & 0 & 0 & 0 & 0 & 0 & 0 & 0 & 16 \\
\hline Paracaprella pusilla & 0 & 0 & 0,5 & 0 & 0 & 0 & 0,5 & 0 & 0 & 0 & 1 \\
\hline Paracaprella tenuis & 0 & 0 & 1 & 0 & 2,5 & 0,5 & 0 & 0,5 & 0 & 0 & 8 \\
\hline TOTAL POR ESTAÇÃO/ ESTRATO & 5,5 & 16,5 & 159 & 18,5 & 22 & 31,5 & 24 & 13 & 95 & 20,5 & 828,5 \\
\hline
\end{tabular}


Anexo VII - Densidade das espécies encontradas no Estrato de Meio (M) na campanha de verão (fevereiro de 2006) nas estações amostradas na Plataforma Continental da Baixada Santista.

\begin{tabular}{|c|c|c|c|c|c|c|c|c|c|c|c|c|c|c|c|c|c|c|c|}
\hline Espécies & $1 \mathrm{M}$ & $2 \mathrm{M}$ & $3 \mathrm{M}$ & $4 M$ & $5 \mathrm{M}$ & $6 \mathrm{M}$ & $7 \mathrm{M}$ & $8 M$ & $10 \mathrm{M}$ & $11 \mathrm{M}$ & $14 M$ & $15 \mathrm{M}$ & $16 M$ & $17 \mathrm{M}$ & $18 \mathrm{M}$ & $19 M$ & $20 M$ & $21 \mathrm{M}$ & TOTAL ESPÉCIES \\
\hline Ampelisca brevisimulata & 0 & 1 & 0 & 0 & 0 & 1 & 0 & 0 & 0 & 0 & 1 & 0 & 0 & 0 & 0 & 1,5 & 0,5 & 0 & 5 \\
\hline Ampelisca cristata & 0 & 0 & 0 & 0 & 0 & 0,5 & 0 & 0 & 0 & 0 & 0,5 & 0 & 0 & 0 & 0 & 0 & 0 & 0 & 1 \\
\hline Ampelisca moreirai & 0 & 0,5 & 0 & 0 & 0 & 0 & 0 & 0 & 0 & 0 & 0 & 0,5 & 0 & 0 & 0 & 0 & 0 & 0 & 1 \\
\hline Ampelisca paria & 0 & 0 & 0 & 0 & 0 & 0,5 & 0 & 0 & 0 & 0 & 0 & 0 & 0 & 0 & 1 & 0 & 0 & 0 & 1,5 \\
\hline Ampelisca rodriguesi & 0 & 0 & 0 & 0,5 & 0 & 0 & 0 & 0 & 0 & 0 & 0 & 0 & 0 & 0 & 0 & 0 & 0 & 0 & 0,5 \\
\hline Ampelisca subtropicalis & 0 & 0 & 0,5 & 0 & 0 & 0 & 0 & 0 & 0 & 0 & 0 & 0 & 0 & 0 & 0 & 0 & 0 & 0 & 0,5 \\
\hline Gitanopsis sp. & 0 & 0,5 & 0 & 0 & 0 & 0,5 & 0 & 0,5 & 0 & 0 & 0 & 0 & 0 & 1 & 0 & 0 & 0 & 0 & 2,5 \\
\hline Lembos sp. & 0 & 0 & 0 & 0,5 & 0 & 0 & 0 & 0 & 0 & 0 & 0 & 0 & 0 & 0 & 0 & 0 & 0 & 0 & 0,5 \\
\hline Liljeborgia quinquedentata & 0 & 2 & 0,5 & 0 & 0 & 1,5 & 0 & 0 & 0 & 0 & 0 & 1,5 & 0 & 0 & 0,5 & 0 & 0 & 0 & 6 \\
\hline Resupinus coloni & 0 & 0 & 0 & 0 & 0 & 0 & 0 & 0 & 0 & 0 & 1,5 & 0,5 & 0 & 0 & 0 & 0 & 0 & 0 & 2 \\
\hline Pseudomegamphopus sp.n. & 0 & 0,5 & 0 & 0 & 0 & 0 & 0 & 0 & 0 & 0 & 1 & 0 & 0 & 0 & 0 & 0 & 0 & 0 & 1,5 \\
\hline Monoculodes nyei & 0 & 0 & 0 & 0 & 0 & 0 & 0 & 0 & 0 & 0 & 0,5 & 0 & 0 & 0,5 & 0 & 0 & 0 & 0 & 1 \\
\hline Oediceroides cinderella & 0 & 0 & 0 & 0 & 0 & 0 & 0 & 0 & 0 & 0,5 & 0 & 0 & 0 & 0 & 0 & 0 & 0 & 0 & 0,5 \\
\hline Paramonoculopsis acuta & 0 & 0 & 0 & 0 & 0 & 0 & 0 & 0 & 0 & 0 & 0 & 0 & 0,5 & 0 & 0 & 0 & 0 & 0 & 0,5 \\
\hline Ampelisciphotis podophthalma & 0 & 0 & 0 & 1,5 & 0 & 0 & 0 & 0 & 0 & 0 & 0 & 0 & 0 & 0 & 0 & 0 & 0 & 0 & 1,5 \\
\hline Photis brevipes & 0 & 0,5 & 0 & 0 & 0 & 1 & 0 & 0 & 0 & 0 & 1 & 0 & 0 & 0 & 0 & 0 & 0 & 0 & 2,5 \\
\hline Photis longicaudata & 0 & 0 & 0 & 0,5 & 0 & 0 & 0 & 0 & 0 & 0 & 0 & 0 & 0 & 0 & 0 & 0 & 0 & 0 & 0,5 \\
\hline Heterophoxus videns & 0 & 0 & 1 & 0 & 0 & 0 & 0 & 0 & 0 & 0 & 0 & 0 & 0 & 0 & 0 & 0 & 1 & 0,5 & 2,5 \\
\hline Metharpinia sp.n. & 0 & 6,5 & 0 & 0 & 0 & 0 & 0 & 0 & 0 & 0 & 0 & 0 & 0 & 0 & 0 & 0 & 5 & 0 & 11,5 \\
\hline Metharpina iado & 0 & 0 & 0 & 0 & 0 & 0 & 0 & 0 & 0 & 0 & 0 & 0,5 & 0 & 0 & 0 & 0 & 0 & 0 & 0,5 \\
\hline Microphoxus moaresi & 0 & 0 & 0 & 0 & 0,5 & 1,5 & 0 & 0 & 0,5 & 0 & 0 & 0 & 0 & 1 & 1 & 0 & 0 & 0 & 4,5 \\
\hline Pseudoharpinia dentata & 0 & 0 & 2 & 0 & 0 & 0 & 0 & 0 & 0 & 0 & 0 & 0 & 0 & 0 & 0 & 0 & 0 & 0 & 2 \\
\hline Eudevenopus gracilipes & 0,5 & 0 & 0 & 0 & 0 & 0 & 0 & 0 & 0 & 0 & 0,5 & 0 & 0 & 0 & 0 & 0,5 & 0 & 0 & 1,5 \\
\hline Parametopella ninis & 0 & 0 & 0 & 0,5 & 0 & 0 & 0 & 0 & 0 & 0 & 0 & 0 & 0 & 0 & 0 & 0 & 0 & 0 & 0,5 \\
\hline Tiron tropakis & 0 & 0 & 0 & 0,5 & 0 & 0 & 0 & 0 & 0 & 0 & 0 & 0 & 0 & 0 & 0 & 0 & 0 & 0 & 0,5 \\
\hline Carangolia sp. & 0 & 0 & 0 & 0 & 0 & 0 & 0 & 0 & 0 & 0 & 0 & 0 & 0 & 0 & 0 & 0 & 0 & 0,5 & 0,5 \\
\hline Urothoe sp.n. & 0 & 0 & 0 & 0 & 0 & 0 & 0 & 0 & 0 & 0 & 0 & 0 & 0 & 0 & 0 & 0 & 5 & 0 & 5 \\
\hline Paracaprella tenuis & 0,5 & 0 & 0 & 0 & 0 & 0 & 0,5 & 0 & 0 & 0 & 0 & 0 & 0 & 0 & 0 & 0 & 0 & 0 & 1 \\
\hline TOTAL POR ESTAÇÃO/ ESTRATO & 1 & 11,5 & 4 & 4 & 0,5 & 6,5 & 0,5 & 0,5 & 0,5 & 0,5 & 6 & 3 & 0,5 & 2,5 & 2,5 & 2 & 11,5 & 1 & 58,5 \\
\hline
\end{tabular}


Anexo VIII - Densidade das espécies encontradas no Estrato Inferior na campanha de verão (fevereiro de 2006) nas estações amostradas na Plataforma Continental da Baixada Santista.

\begin{tabular}{|c|c|c|c|c|c|c|c|c|c|c|c|c|c|c|c|c|}
\hline Espécies & $2 \mathrm{~F}$ & $5 \mathrm{~F}$ & $6 \mathrm{~F}$ & $7 F$ & $8 \mathrm{~F}$ & $10 \mathrm{~F}$ & $12 \mathrm{~F}$ & $14 \mathrm{~F}$ & $15 \mathrm{~F}$ & $16 \mathrm{~F}$ & $17 \mathrm{~F}$ & $18 \mathrm{~F}$ & $19 \mathrm{~F}$ & $20 \mathrm{~F}$ & $21 \mathrm{~F}$ & TOTAL ESPÉCIES \\
\hline Ampelisca cristata & 0 & 0 & 0 & 0 & 0,5 & 0,5 & 0 & 0 & 0 & 0 & 0,5 & 0 & 0 & 0 & 0 & 1,5 \\
\hline Ampelisca paria & 0 & 0 & 0 & 0 & 0 & 0 & 0 & 0 & 0 & 0,5 & 0 & 0 & 0 & 0 & 0 & 0,5 \\
\hline Ampelisca romigi & 0 & 0 & 0 & 0 & 0 & 0 & 0 & 0 & 0 & 0 & 0 & 0 & 0 & 0,5 & 0 & 0,5 \\
\hline Gitanopsis sp. & 0,5 & 0 & 0 & 0 & 0 & 0 & 0 & 0 & 0 & 0 & 0 & 0 & 0 & 0,5 & 0 & 1 \\
\hline Lembos sp. & 0,5 & 0 & 0 & 0 & 0 & 0 & 0 & 0 & 0 & 0 & 0 & 0 & 0 & 0 & 0 & 0,5 \\
\hline Cheirophotis neotropicalis & 0 & 1,5 & 0 & 0 & 0 & 0 & 0 & 0 & 0 & 0,5 & 0 & 0 & 0 & 0 & 0 & 2 \\
\hline Liljeborgia quinquedentata & 1 & 0 & 1 & 2 & 0 & 0 & 0 & 0 & 0 & 0 & 0 & 0 & 0 & 0 & 0 & 4 \\
\hline Tryphosella sp. 1 & 0 & 0 & 0 & 0 & 0 & 0 & 0 & 0 & 0 & 0 & 0 & 0 & 0 & 0,5 & 0 & 0,5 \\
\hline Tryphosella sp. 2 & 0 & 0 & 0 & 0 & 0 & 0 & 0 & 0 & 0,5 & 0 & 0 & 0 & 0 & 0,5 & 0 & 1 \\
\hline Monoculodes nyei & 0 & 0 & 0 & 0 & 0 & 0 & 0 & 0 & 0 & 0 & 0 & 0 & 0,5 & 0 & 0 & 0,5 \\
\hline Paramonoculopsis acuta & 0 & 0 & 0 & 0 & 0 & 0 & 0 & 0 & 0 & 0 & 0 & 0 & 0 & 1 & 0 & 1 \\
\hline Synchelidium americanum & 0 & 0 & 0 & 0 & 0 & 0 & 0 & 0 & 0 & 0 & 0 & 0 & 0 & 0,5 & 0 & 0,5 \\
\hline Halicoides ? sp. & 0 & 0 & 0 & 0 & 0 & 0 & 0 & 0 & 0 & 0 & 0 & 0 & 0 & 2 & 0 & 2 \\
\hline Photis longicaudata & 0 & 0 & 0 & 0 & 0 & 0 & 0 & 0 & 0 & 0 & 0 & 0 & 0 & 0,5 & 0 & 0,5 \\
\hline Metharpinia sp.n. & 1 & 0 & 0 & 0 & 0 & 0 & 0 & 0 & 0 & 0 & 0 & 0 & 0 & 11 & 0 & 12 \\
\hline Microphoxus moaresi & 0,5 & 0 & 0 & 0 & 0 & 0 & 0 & 0 & 0 & 0 & 0 & 0 & 0 & 0 & 0 & 0,5 \\
\hline Pseudoharpinia dentata & 0 & 0 & 0 & 0 & 0 & 0 & 1,5 & 0 & 0 & 0 & 0 & 0 & 0 & 0 & 1 & 2,5 \\
\hline Eudevenopus gracilipes & 0 & 0 & 0 & 0 & 0,5 & 0 & 0 & 0 & 0 & 0 & 0 & 0 & 0,5 & 0 & 0 & 1 \\
\hline Tiron tropakis & 0 & 0 & 0 & 0 & 0 & 0 & 0 & 0 & 0 & 0 & 0 & 0 & 0 & 1 & 0 & 1 \\
\hline Urothoe sp.n. & 0 & 0 & 0 & 0 & 0 & 0 & 0 & 0 & 0 & 0 & 0 & 0 & 0 & 3,5 & 0 & 3,5 \\
\hline Huerpa ? sp. & 1 & 0 & 0 & 0 & 0 & 0 & 0 & 0,5 & 0 & 0 & 0 & 0 & 0 & 0 & 0 & 1,5 \\
\hline Paracaprella pusilla & 0 & 0 & 0 & 0 & 0 & 1 & 0 & 0 & 0 & 0 & 0 & 0,5 & 0 & 0 & 0 & 1,5 \\
\hline Paracaprella tenuis & 0 & 0 & 0,5 & 0 & 0 & 0 & 0 & 0 & 0 & 0 & 0 & 0 & 0 & 0 & 0 & 0,5 \\
\hline TOTAL POR ESTAÇÃO/ ESTRATO & 4,5 & 1,5 & 1,5 & 2 & 1 & 1,5 & 1,5 & 0,5 & 0,5 & 1 & 0,5 & 0,5 & 1 & 21,5 & 1 & 40 \\
\hline
\end{tabular}


Anexo IX - Biomassa média (mg) e o desvio padrão respectivo, para cada estação amostrada nas duas campanhas da Plataforma Continental Adjacente.

\begin{tabular}{ccccc}
\hline Estações & \multicolumn{2}{c}{ Inverno } & \multicolumn{2}{c}{ Verão } \\
\cline { 2 - 5 } & Média & $\sigma$ & Média & $\sigma$ \\
\hline $\mathbf{1}$ & 6,96 & 3,309 & 13,96 & 17,176 \\
$\mathbf{2}$ & 70,70 & 31,113 & 41,10 & 34,507 \\
$\mathbf{3}$ & 56,55 & 64,842 & 48,40 & 55,154 \\
$\mathbf{4}$ & 40,56 & 25,251 & 36,11 & 13,584 \\
$\mathbf{5}$ & 4,15 & 0,778 & 3,16 & 0,219 \\
$\mathbf{6}$ & 25,80 & 10,324 & 30,95 & 11,526 \\
$\mathbf{7}$ & 18,36 & 16,058 & 8,71 & 2,553 \\
$\mathbf{8}$ & 19,56 & 21,977 & 11,81 & 10,600 \\
$\mathbf{9}$ & 10,21 & 3,380 & 6,45 & 3,606 \\
$\mathbf{1 0}$ & 5,50 & 0,424 & 9,61 & 7,078 \\
$\mathbf{1 1}$ & 68,25 & 67,953 & 7,51 & 6,074 \\
$\mathbf{1 2}$ & 7,40 & 2,121 & 4,00 & 0,283 \\
$\mathbf{1 3}$ & 9,01 & 3,118 & 4,40 & 1,414 \\
$\mathbf{1 4}$ & 25,50 & 30,688 & 24,11 & 29,981 \\
$\mathbf{1 5}$ & 9,06 & 0,212 & 7,80 & 3,253 \\
$\mathbf{1 6}$ & 8,11 & 3,825 & 5,40 & 2,687 \\
$\mathbf{1 7}$ & 5,25 & 2,192 & 7,01 & 3,246 \\
$\mathbf{1 8}$ & 25,40 & 2,404 & 8,06 & 0,912 \\
$\mathbf{1 9}$ & 4,50 & 4,101 & 8,41 & 10,734 \\
$\mathbf{2 0}$ & 40,06 & 0,643 & 41,05 & 7,425 \\
$\mathbf{2 1}$ & 6,45 & 8,415 & 15,40 & 6,505 \\
\hline
\end{tabular}


Anexo X - Levantamento dos limites de distribuição batimétrica dos Amphipoda.

\begin{tabular}{|c|c|c|c|c|c|}
\hline \multirow{2}{*}{\multicolumn{6}{|c|}{ Subordem Gammaridea }} \\
\hline & & & & & \\
\hline \multicolumn{6}{|l|}{ Ampeliscidae } \\
\hline Ampelisca sp.n. 1 & $34,7-58$ & & & & \\
\hline Ampelisca sp.n. 2 & 58 & & & & \\
\hline Ampelisca brevisimulata & $26-58$ & $30-60$ & $20-147$ & $20-108$ & $1-176$ \\
\hline Ampelisca cristata & $26-85$ & $30-74$ & $27-88$ & $20-70$ & \\
\hline Ampelisca moreirai & $26-85$ & & & & \\
\hline Ampelisca paria & $14-32,5$ & (12)-37 & $22-25$ & $15-47$ & \\
\hline Ampelisca pugetica & 27-96 & $30-74$ & $15-168$ & $15-77$ & $18-194$ \\
\hline Ampelisca rodriguesi & $50-85$ & & & & \\
\hline Ampelisca romigi & $19-96$ & & & & \\
\hline Ampelisca subtropicalis & 58 & & & & \\
\hline \multicolumn{6}{|l|}{ Amphilochidae } \\
\hline Gitanopsis sp. & $26-85$ & & & & \\
\hline \multicolumn{6}{|l|}{ Dexaminidae } \\
\hline Kamehatylus sp. & $14-29$ & & & & \\
\hline \multicolumn{6}{|l|}{ Eusiridae } \\
\hline Eusirus sp. & 58 & & & & \\
\hline \multicolumn{6}{|l|}{ Lilje borgiidae } \\
\hline Liljeborgia dubia & 24-58 & & & $21-76$ & \\
\hline Liljeborgia quinquedentata & $14-58$ & $15-69$ & $20-115$ & $18-101$ & águas rasas- 790 \\
\hline Listriella titinga & $32-56$ & 39 & $26-110$ & $18-45$ & $1 \mathrm{~m}-27$ \\
\hline \multicolumn{6}{|l|}{ Lysianassoidea } \\
\hline Prachynella sp. & 58 & & & & \\
\hline Tryphosella sp. 1 & $20-85$ & & & & \\
\hline Tryphosella sp. 2 & $26-85$ & & & & \\
\hline \multicolumn{6}{|l|}{ Melitidae } \\
\hline Ceradocus sp. & 85 & & & & \\
\hline Dulichiella anisochir & 58 & $22-69$ & $15-168$ & $36-73$ & \\
\hline
\end{tabular}


Anexo XI - Levantamento dos limites de distribuição batimétrica dos Amphipoda.

\begin{tabular}{|c|c|c|c|c|c|}
\hline & ECOSAN & Santos (1999) & Gallerani (1997) & Valério-Berardo (1992) & Wakabara (1991) \\
\hline Giberosus myersi & $20-34$ & & & & $0-56$ \\
\hline Maera sp. & $29-97$ & & & & \\
\hline Resupinus coloni & $14-85$ & & & & $0-15$ \\
\hline \multicolumn{6}{|l|}{ Oedice rotidae } \\
\hline Monoculodes nyei & $26-32,5$ & & & $43-36$ & $1-166$ \\
\hline Paramonoculopsis acuta & $15-51$ & & & & \\
\hline Oediceroides cinderella & $50-57$ & & & & \\
\hline Synchelidium americanum & $28,8-85$ & & & & $20-54$ \\
\hline Westwoodilla rectirostris & 85 & & & & $24-166$ \\
\hline \multicolumn{6}{|l|}{ Pardaliscidae } \\
\hline Halicoides cf.sp. & $29-56$ & & & & \\
\hline \multicolumn{6}{|l|}{ Phoxocephalidae } \\
\hline Heterophoxus videns & $28-96$ & $24-69$ & $18-150$ & $18-50$ & $17-25$ \\
\hline Metharpinia sp.n. & $28-58$ & & & & \\
\hline Metharpinia aff. iado & $32-85$ & & & & \\
\hline Microphoxus moaresi & $14-85$ & & & & \\
\hline Pseudoharpinia dentata & $28-97$ & $25-200$ & $25-200$ & $17-117$ & \\
\hline \multicolumn{6}{|l|}{ Platyischnopidae } \\
\hline Eudevenopus gracilipes & $19-32$ & & & & \\
\hline Tiburonella viscana & $29-34$ & $15-60$ & $15-60$ & $15-41$ & $0-4$ \\
\hline \multicolumn{6}{|l|}{ Synopiidae } \\
\hline Syrrhoe crenulata & $50-56$ & & & 73 & $97-224$ \\
\hline Tiron biocellata & $28-85$ & & & & \\
\hline Tiron tropakis & $25-85$ & $13-74$ & & $17-116$ & $0-136$ \\
\hline \multicolumn{6}{|l|}{ Stenothoidae } \\
\hline Parametopella ninis & $26-85$ & $18-50$ & $18-50$ & $48-116$ & \\
\hline \multicolumn{6}{|l|}{ Urohaustoriidae } \\
\hline Huerpa sp. & $15-34$ & & & & \\
\hline
\end{tabular}


Anexo XII- Levantamento dos limites de distribuição batimétrica dos Amphipoda.

\section{Urothoidae}

Carangolia sp.

ECOSAN

Santos (1999)

Gallerani (1997)

Valério-Berardo (1992)

Wakabara (1991)

Urothoe sp.n.

28,8-96

Subordem Corophiidea

$50-97$

\section{Aoridae}

Lembos sp.

$27-97$

Ampithoidae

Ampithoe ramondi

Corophii idae

Monocorophium acherusicum

Leptocheirus cf. sp.

Cheirophotis megacheles

Cheirophotis neotropicalis

Caprellidae

Paracaprella pusilla

Paracaprella tenuis

\section{Podoceridae}

Podocerus brasiliensis

$29,1-85$

$22-98$

Neomegamphopodidae

Pseudomegamphopus barnardi

Aorcho cf. sp.

\section{4-85}

otidae

Ampelisciphotis podophthalma

Photis brevipes 